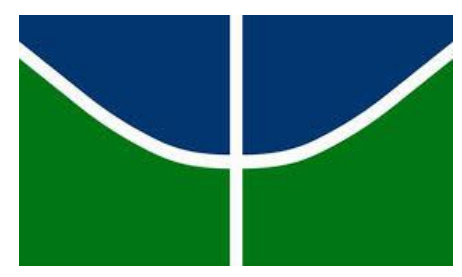

UNIVERSIDADE DE BRASÍLIA INSTITUTO DE CIÊNCIAS BIOLÓGICAS DEPARTAMENTO DE BIOLOGIA CELULAR

MODELOS CARACTERIZANDO A INTERAÇÃO ENTRE AS TOXINAS DA FAMÍLIA CRY1A DE BACILLUS THURINGIENIS E O RECEPTOR BT-R1 DE MANDUCA SEXTA

DIOGO MARTINS DE SÁ

BRASÍLIA - BRASIL

MARÇO DE 2015 
Universidade de Brasília

Instituto de Ciências Biológicas

Departamento de Biologia Celular

Programa de Pós-Graduação em Biologia Molecular

Modelos Caracterizando a Interação entre as Toxinas da Família Cry1A de Bacillus thuringiensis e o Receptor BT- $\mathrm{R}_{1}$ de Manduca sexta

Diogo Martins de Sá

Dissertação submetida ao programa de Pósgraduação em Biologia Molecular da UnB como requisito parcial à obtenção de Mestre em Biologia Molecular.

Orientadora: Dra. Maria Fátima Grossi de Sá

Brasília - DF

Março de 2015 
Autorizo a reprodução e divulgação total ou parcial deste trabalho, por qualquer meio convencional ou eletrônico, para fins de estudo e pesquisa, desde que citada a fonte.

Ficha Catalográfica

Instituto de Ciências Biológicas

Departamento de Biologia Celular da Universidade de Brasília

Programa de Pós-graduação em Biologia Molecular

\section{Martins-de-Sá, Diogo.}

Modelos caracterizando a interação entre as toxinas da família Cry1A de Bacillus thuringiensis e o receptor BT-R1 de Manduca sexta / Diogo Martins de Sá; orientadora Maria Fátima Grossi de Sá - Brasília, 2015.

Dissertação (Mestrado) - Universidade de Brasília, 2015.

1. Cry1A.

3. Modelagem de Proteínas

5. Dinâmica Molecular
2. BT-R1.

4. Docking

6. Interação Receptor-Ligante

\section{Para citar este documento, utilize:}

Martins-de-Sa, D., Modelos caracterizando a interação entre as toxinas da família Cry1A de Bacillus thuringiensis e o receptor BT- $\mathrm{R}_{1}$ de Manduca sexta. MSc, Universidade de Brasília, 2015. 


\title{
MODELOS CARACTERIZANDO A INTERAÇÃO ENTRE AS TOXINAS DA FAMÍLIA CRY1A DE BACILLUS THURINGIENIS E O RECEPTOR BT-R1 DE MANDUCA SEXTA
}

Diogo Martins de Sá

Dissertação submetida ao Programa de Pós-Graduação em Biologia Molecular do Departamento de Biologia Celular da Universidade de Brasília como parte dos requisitos necessários para a obtenção do grau de Mestre em Biologia Molecular

\section{Banca Examinadora}

Dra. Maria Fátima Grossi de Sá Embrapa Recursos Genéticos e Biotecnologia Orientadora

\author{
Dr. Luciano Paulino Silva \\ Embrapa Recursos Genéticos e Biotecnologia \\ Prof. Dr. João Alexandre Ribeiro Gonçalves Barbosa \\ Universidade de Brasília \\ Profa. Dra. Sônia Maria de Freitas \\ Universidade de Brasília
}




\section{Dedicatória}

Dedico este documento à minha mãe, meu maior exemplo de dedicação e perseverança, e em memória ao meu pai, o melhor ser humano e cientista que eu tive o prazer de conviver.

Obrigado por todo amor e paciência. 


\section{Agradecimentos}

À Universidade de Brasília e ao Programa de Pós-Graduação em Biologia Molecular, em especial à secretária Ana Hilda Tibet, por sua disposição em me ajudar em todas as questões burocráticas desse mestrado.

À EMBRAPA Recursos Genéticos e Biotecnologia, por ser um centro de excelência que permitiu o desenvolvimento desse projeto.

À Coordenação de Aperfeiçoamento de Pessoal de Nível Superior (CAPES), pela bolsa que me foi concedida.

À minha orientadora, Maria Fátima Grossi de Sá, por proporcionar todas as oportunidades que um aluno pode desejar e por todo o comprometimento para com meu crescimento cientifico.

À minha irmã, Maíra Grossi de Sá, minha maior fã e protetora, por todo o amor e carinho que recebo dela.

Ao Wagner Alexandre Lucena, por todos os ensinamentos em modelagem e dinâmica molecular de proteínas, e por ter me estimulado a escrever este projeto de mestrado.

À Isabela Tristan Lourenço, minha primeira instrutora na bancada de laboratório, por tudo que ela me ensinou e pela amizade que permaneceu.

Ao Prof. Werner Treptow, por todos seus conselhos e instruções como meu Tutor no Programa de Pós-graduação em Biologia Molecular.

Aos Professores Sonia Maria de Freitas, João Alexandre Ribeiro Gonçalves Barbosa e Napoleão Valadares, por terem me recebido no Laboratório de Biofísica Molecular da UnB e por todas as colaborações a este trabalho.

Aos amigos da Escola das Nações, Guilherme "Gai", Diogo "Manso", Diego "Negro", Felipe "Sali", Bernard "Koreia", George "Éba" e Charles "Éri", meus cúmplices, por me acompanharem há inacreditáveis 18 anos.

Aos amigos do LIMPP, Fernando Fonseca, Leonardo Pepino, Janaína de Paula, Dijair Souza, Alexandre Firmino, Antonio Américo, Rodrigo Fragoso, Osmundo Brilhante, Rayssa Garcia, Patrícia Pelegrini e Joaquin Paixão, por todos os momentos de descontração e discussão científica.

Aos colegas do LIMPP, pelo respeito e profissionalismo durante toda minha experiência no laboratório.

Por fim, agradeço à Janis Joplin, B.B. King e Paul Simon pelos álbuns "In Concert", "Got My Mojo Working" e "Graceland", respectivamente, que serviram de trilha sonora durante grande parte do processo de elaboração e digitação desse documento. 
"O tempo e sua inabalável capacidade de seguir em frente..."

Não há líder nato maior que o tempo

Ele não discute, não pede sua opinião, não perdoa

Ainda assim, ele nos ensina, nos aperfeiçoa

É assim nos sentimentos

É assim na Natureza

O tempo e sua inabalável capacidade de seguir em frente

E de tão generoso, nos acompanha

Pois não se engane, há um tempo para cada um de nós

Perceptível na felicidade daqueles que o compartilham

E na mazela dos distraídos.

O tempo, ora, é sempre atual, ele vive o presente

Acompanhá-lo é andar em estrada incerta

E que dádiva a incerteza!

A incerteza nos desafia, nos arrebata

É a alma do livre arbítrio e do acaso

Certeza, só que nosso tempo acaba

E para todo o resto, o incerto

Há quem preveja certeza no futuro

Eu escolhi interpretar as coisas incertas

$\mathrm{Na}$ ciência e na vida,

Para compreender de onde vim e no que me tornei

Para abraçar o incerto a minha frente

Para apreciar a beleza ao meu redor

E para lembrar o valor daquilo que se foi.

(Autoria própria) 


\section{Resumo}

O Bacillus thuringiensis é uma bactéria gram positiva pertencente ao grupo Bacillus cereus, mas se distingue de outras espécies deste grupo por produzir, durante a esporulação, inclusões cristalinas contendo predominantemente uma ou mais proteínas de ação inseticida (toxinas Cry e Cyt), também chamadas de $\delta$-endotoxinas. Por definição, toxinas Cry exibem toxicidade experimentalmente verificável a um organismo alvo, ou possuem similaridade significativa de sequencia à uma toxina Cry já descrita. A toxicidade de Cry1 Ab é amplamente relatada para larvas da mariposa Manduca sexta e estudos indicam que o domínio II é responsável pelo reconhecimento específico dessa toxina ao receptor no intestino do inseto. Cry1Aa, Cry1Ab e Cry1Ac possuem 82 a $90 \%$ de identidade de resíduos de aminoácidos e a interação dessas proteínas com receptores primários do tipo caderina é descrita como um importante passo para a correta remoção da $\alpha$-hélice 1 no domínio I e subsequente desencadeamento de eventos que levam à morte do inseto. Usando-se de modelagem por homologia e docking molecular, foram selecionados dois modelos descrevendo as interações entre o receptor de $M$. sexta, BT- $\mathrm{R}_{1}$, e a toxina Cry1 Ab. Estes modelos foram submetidos à simulações por dinâmica molecular clássica e avaliados quanto a diversos aspectos de sua estrutura. Um total de 12 blocos de interação foram identificados para cada proteína e estudados quanto às suas propriedade biofísicas, cada qual constituído por uma região da sequência de aminoácidos de suas respectivas proteínas. As medidas de RMSD ao fim da dinâmica mostraram que os sítios de ligação ao receptor apresentam deformações menores que próprio receptor, indicando que a ligação à $\mathrm{Cry} 1 \mathrm{Ab}$ estabiliza estas regiões. Mais que isso, os termos intermoleculares de energia de curta distância mostraram um declínio contínuo e uma tendência de atração entre as duas proteínas. Todas as ligações de hidrogênio e pontes salinas foram mapeadas e caracterizadas de acordo com sua persistência e distância média durante a dinâmica. Por último, foi avaliado o potencial eletrostático de cada bloco de interação, o que permitiu inferir as regiões que direcionam a ligação específica da toxina ao receptor. Para validar os modelos, foram sintetizados peptídeos correspondendo a cada bloco de interação para uma análise qualitativa utilizando ressonância plasmônica de superfície (SPR). Resultados preliminares de um dos modelos mostram que o loop 3, notório por sua função no reconhecimento ao receptor, é capaz de ligar-se a uma região nunca antes relatada dos receptores tipo caderina. Essa nova região possui um perfil de 
hidropaticidade similar ao do epitopo de um anticorpo específico ao loop 3 e, quando comparamos medidas entre $\mathrm{pH}$ 7,4 e pH 9,0 em experimentos de SPR, é possível observar uma ligação de mesma intensidade entre essas duas regiões usando-se 266 vezes menos concentração de analito em $\mathrm{pH}$ básico. $\mathrm{O}$ pH fisiológico do intestino de $M$. sexta é aproximadamente 9,0, o que indica que um dos modelos é capaz de reproduzir aspectos da interação in vivo. $\mathrm{O}$ prosseguimento deste trabalho, através de técnicas in silico e experimentos in vitro, deve indicar se ambos modelos são plausíveis de ocorrer, ou se um dos modelos é preterido. No geral, esses modelos permitiram observar o comportamento da toxina enquanto ligada ao receptor e contribuem para $\mathrm{o}$ entendimento de muitos dos experimentos in vitro realizados envolvendo as toxinas da família Cry1A e os receptores tipo caderina.

Palavras-chave: ligação proteína-proteína, dinâmica clássica, docking molecular, modelagem comparativa 


\section{Abstract}

Cry1Ab is widely described as toxic to Manduca sexta larvae and extensive substitution of loop residues in domain II suggests that this region is responsible for specific binding to receptor. Cry1 Aa, Cry1 Ab, and Cry1Ac share 82 to $90 \%$ amino acid residue identity to one another and their interaction with cadherin-like receptors has been described as an important step for the correct removal of alpha-helix1 in domain I and subsequent events leading to the insect's death. After homology modeling and a selective protein docking, two models describing the interactions of Cry1Ab to the $M$. sexta cadherin-like receptor, BT- $\mathrm{R}_{1}$, were assessed using molecular dynamics simulations. A total of 12 binding regions were identified for each protein and their biophysical properties were further evaluated. Binding sites in the receptor were shown to have lower RMSD measures than the entire receptor, indicating that the binding of Cry1 Ab stabilizes these regions. Also, Van der Waals and Coulomb short-range energy terms were measured for the receptor-toxin complex and showed an attraction tendency, with decreasing energy throughout the entire simulation. All intermolecular hydrogen bonds and salt bridges were identified and characterized according to persistence of existence and mean distances, respectively, as well as their participating residues. Lastly, electrostatic potential for each binding site was assessed, permitting to infer regions that guide specific binding of toxin to receptor. To further investigate the importance of each binding region and validate our model, we synthesized peptides corresponding to each of these regions. Result for one model show that loop 3, notorious for receptor recognition, binds a region previously unidentified in Manduca sexta cadherin-like receptor. This new toxin binding region shows the same hydropathicity profile of an antibody epitope previously described to bind specifically to loop 3 . Most interestingly, binding occurs with over 266-fold less peptide concentration in $\mathrm{pH} 9.0$ than in $\mathrm{pH}$ 7.4. The physiological $\mathrm{pH}$ in the insect midgut is approximately 9.0, which corroborates that at least one of the models reproduces in-vivo interaction. Ongoing work will show if both models are plausible to occur, or if one of them is preferable to the other. Overall, these models allowed the observation of the toxin's behavior when binding to $\mathrm{BT}-\mathrm{R}_{1}$ and have helped explain many in vitro experiments concerning Cry1 A and cadherin-like receptors.

Key words: protein-protein binding, classic dynamics, molecular docking, homology modeling 


\section{Listas de Abreviações}

\begin{tabular}{|c|c|}
\hline 3D-Cry & Proteína Cry de três domínios \\
\hline BBMV & Brush border membrane vesicle \\
\hline Bin-like & Semelhante às proteínas binárias \\
\hline Bs & Bacillus subtillis \\
\hline $\mathrm{Bt}$ & Bacillus thuringiensis \\
\hline Bti & Bacillus thuringiensis var. israelensis \\
\hline BT-R1 & Receptor 1 de Bacillus thuringiensis \\
\hline CAPRI & Avaliação Crítica da Predição de Interações \\
\hline CDS & Sequência codante \\
\hline CERA & Centro para Avaliação de Risco Ambiental \\
\hline Cfu & Unidades formadoras de colônia \\
\hline Coul & Coulomb \\
\hline $\mathrm{CR}$ & Ectodomínio repetido de caderina \\
\hline CRX & Cristalografia de raio- $\mathrm{x}$ \\
\hline Cry (toxina) & Proteína cristal \\
\hline CTNBio & Comissão Técnica Nacional de Biossegurança \\
\hline Cyt (toxina) & Proteína citolítica \\
\hline D-I & Domínio I de proteínas 3D-Cry \\
\hline D-II & Domínio II de proteínas 3D-Cry \\
\hline D-III & Domínio III de proteínas 3D-Cry \\
\hline
\end{tabular}


$\mathrm{DM}$

EIQ

EXT_MTX-like

FFT

Gal-Nac

$\operatorname{Inh} \mathrm{A}$

$\mathrm{LdH}$

LJ

Ls

MPED

$\mathrm{MpH}$

OGM

ORF

PDB

PFTs

PlcR

PME

PPK

RMSD

RUL

Sip (toxina)

SPC
Docking molecular

Quociente de impacto ambiental

Semelhante às toxinas Epsilon e/ou Mosquitocida

Transformada rápida de Fourier

$\mathrm{N}$-acetil galactosamina

Inibidor A

Ligação de hidrogênio

Lennard-Jones

Lysinbacillus sphaericus

Domínio extracelular próximo a membrana

Modelagem por homologia

Organismo geneticamente modificado

Fase de leitura aberta

Protein Data Bank

Toxinas formadoras de poro

Regulador de fosfolipase C

Somatório de Ewald para malha de partícula

Polifosfato quinase

Deformação média quadrática

Região universal de ligação

Proteína inseticida secretada

Carga pontual única (single point charge) 
SPR

TBR

TM

VdW

Vip (toxina)

XFEL

$\mathrm{ZmA}$
Ressonância plasmônica de superfície

Região de ligação à toxina

Região transmembrana

Van der Waals

Proteína inseticida vegetativa

Laser de raios-X gerado por elétrons livres

Zwittermicina A 


\section{Lista de Figuras}

Figura 1: Célula de Bacillus thuringiensis em esporulação........................................ 23

Figura 2: Microscopia eletrônica da superfície de uma inclusão cristalina..................... 26

Figura 3: Esquema ilustrativo da nomenclatura de toxinas de $\mathrm{Bt}$................................. 35

Figura 4: Árvore filogenética das toxinas Cry e a organização por categorias ............... 36

Figura 5: Organograma dos grupos e famílias de toxinas produzidas por Bt................. 38

Figura 6: Ordens de insetos acometidas pelas toxinas Vip e Sip de Bt......................... 39

Figura 7: Diagrama de Venn entre toxinas de Bt e domínios conservados.................... 40

Figura 8: Hospedeiros suscetíveis às $\delta$-endotoxinas Cry e Cyt................................... 42

Figura 9: Estrutura tridimensional de uma proteína da família 3D-Cry ........................ 46

Figura 10: Tamanho relativo de protoxinas Cry e a posição dos blocos conservados ... 47

Figura 11: Estrutura cristalográfica da protoxina de Cry1 Ac...................................... 48

Figura 12: Representação da repetição de sequências C-terminais................................ 50

Figura 13: Ativação da protoxina em uma proteína ativa. .......................................... 52

Figura 14: Os dois modelos citotóxicos das toxinas 3D-Cry...................................... 54

Figura 15: Relação filogenética de domínios individuais.. ........................................... 61

Figura 16: Exemplos naturais do rearranjo do domínio III. .......................................... 63

Figura 17: Diferentes padrões na produção de inclusões cristalinas em Bt .................... 65

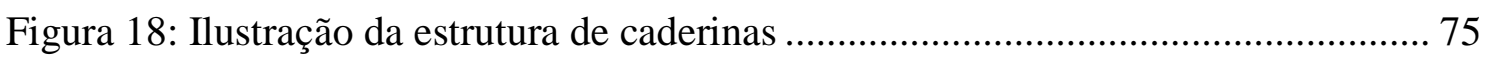

Figura 19: Fluxograma do método de modelagem por homologia. .............................. 76

Figura 20: Representação de uma paisagem de energia livre....................................... 77

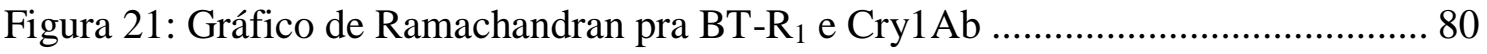

Figura 22: Comparação entre perfis de hidropaticidade de fragmentos de BT-R $\mathrm{R}_{1} \ldots \ldots \ldots . . . .82$

Figura 23: Docking molecular entre toxinas da famila Cry1A e o receptor BT- $\mathrm{R}_{1} \ldots \ldots . .83$

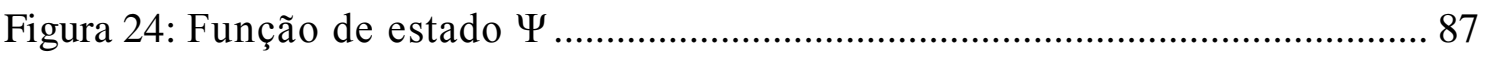

Figura 25: Exemplos de funções de interação em campos de força modernos .... 89

Figura 26: Fluxograma das etapas de uma simulação de dinâmica molecular..... 90

Figura 27: Critério geométrico para a existência de uma ligação de hidrogênio. .......... 95

Figura 28: Medidas de RMSD para Dock1 e Dock2 ................................................. 98

Figura 29: Representação da formação de uma Região de Ligação Universal ............ 100

Figura 30: Medidas individuais de RMSD para RULs de BT-R em Dock1 ............... 104

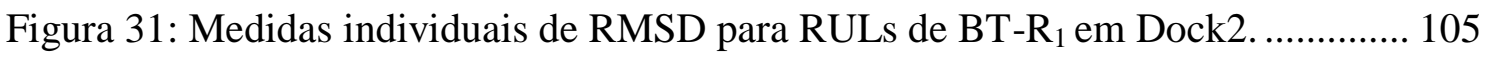


Figura 32: Energias intermoleculares de dispersão e eletrostáticas dos modelos. ........ 106

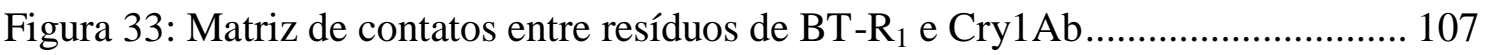

Figura 34: Aumento relativo de contatos feitos por cada resíduo após 76 ns .... 109

Figura 35: Identificação de áreas de integração dos blocos de interação em Dock1 ... 110

Figura 36: Integração da matriz de contatos doss blocos de interação de Cry1 Ab ...... 112

Figura 37: Ensaio de SPR para a interação entre Ab2.5 e CR11.1 em pH 7,4............ 118

Figura 38: Ensaio de SPR para a interação entre Ab2.5 e CR11.1 em pH 9.0............. 119

Figura 39: Ensaio de SPR para a interação entre Ab2.5 e os controles........................ 119

Figura 40: Ensaio de SPR para a interação entre Ab2.5 e CR11.1 mais os controles.. 120

Figura 41: Repetição do ensaio de SPR na presença de $\mathrm{NaCl} 50 \mathrm{mM}$......................... 120

Figura 42: Ensaio de SPR usando baixas concentrações do ligante CR11.1 .............. 121

Figura 43: Sítio ${ }_{1310} \mathrm{LI}_{1311}$ antes e após interação de Ab2.5 com BT-R $\mathrm{R}_{1} \ldots \ldots \ldots \ldots \ldots \ldots \ldots \ldots . . . . . . . . .124$ 


\section{Lista de Tabelas}

Tabela 1: Produtos baseados em cepas naturais de Bt e seus alvos .............................. 27

Tabela 2: Produtos de Bt baseados em conjugação e recombinação.............................. 28

Tabela 3: Vantagens e desvantagens do uso de sprays de Bt ....................................... 29

Tabela 4: Resumo de estruturas cristalográficas resolvidas de toxinas 3D-Cry............. 44

Tabela 5: Número de acesso e região das sequências modeladas. .................................. 76

Tabela 6: Médias de RMSD durante 76 nanossegundos de simulação.......................... 99

Tabela 7: Quantidade total de ligações de hidrogênio nos modelos Dock 1 e Dock2. 101

Tabela 8: As dez ligações de hidrogênio mais persistentes de Dock1 e Dock2 ........... 102

Tabela 9: Regiões Universais de Ligação e as regiões em Dock1 e Dock2 ................. 103

Tabela 10: Resumo das regiões de interação de Dock1 e Dock2 ................................ 116

Tabela 11: Matriz das interações entre todas as regiões universais de ligação............ 122 


\section{Sumário}

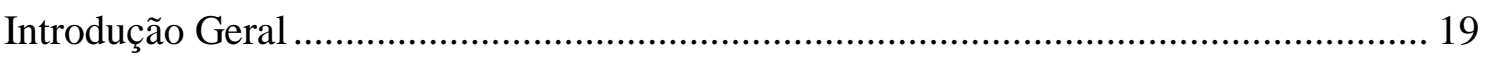

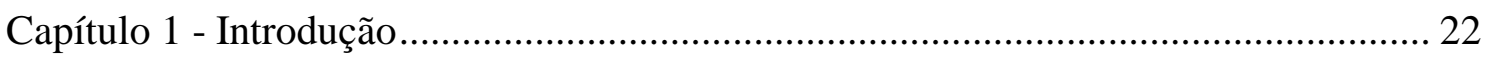

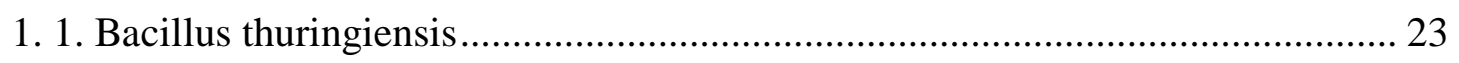

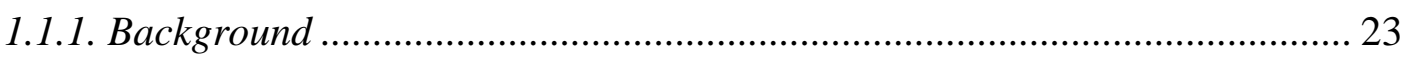

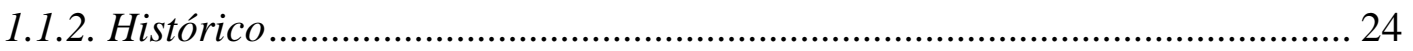

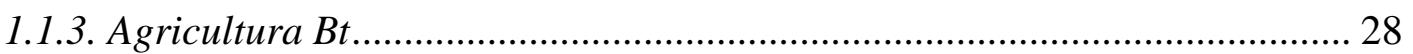

1.1.4. Biossegurança, Meio Ambiente e Economia .................................................. 30

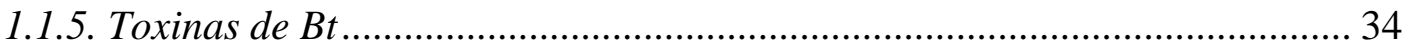

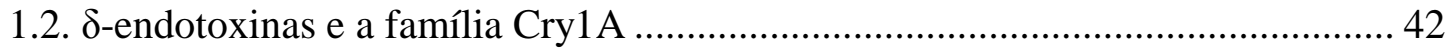

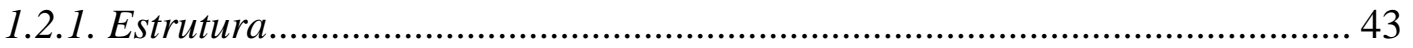

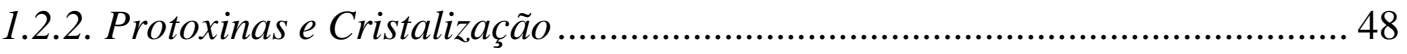

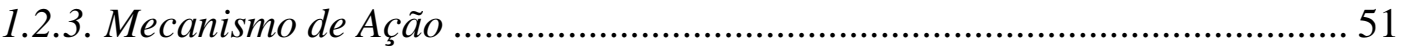

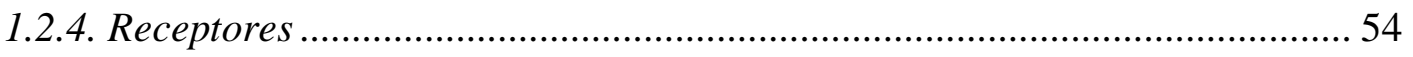

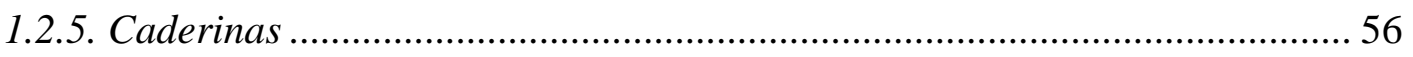

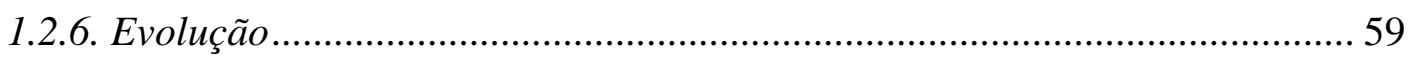

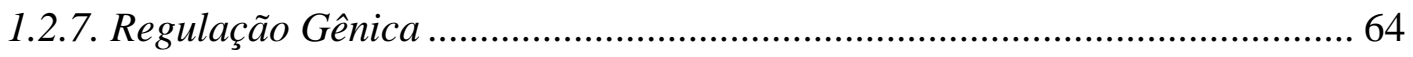

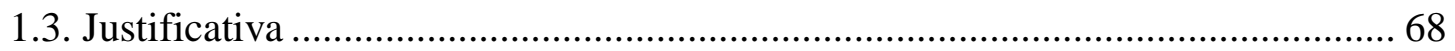

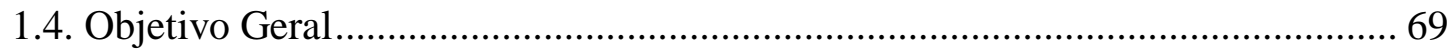

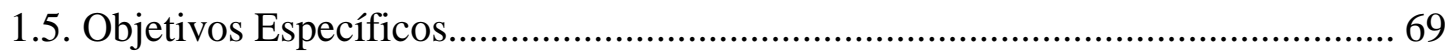

Capítulo 2 - Modelagem por Homologia e Docking …................................................... 70

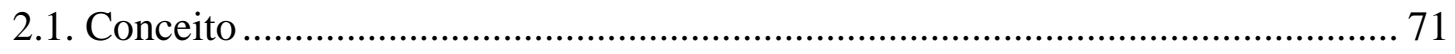

2.1.1. Modelagem por Homologia ........................................................................ 71

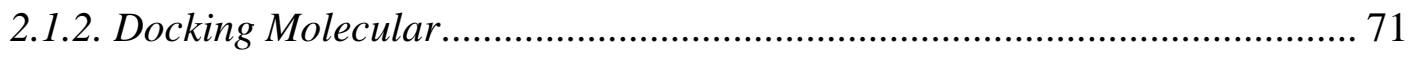

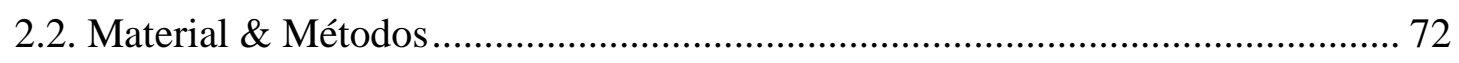

2.2.1. Obtenção de modelos por homologia de sequência ................................... 72

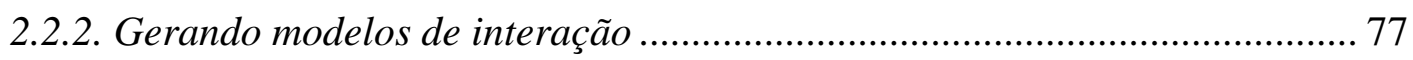




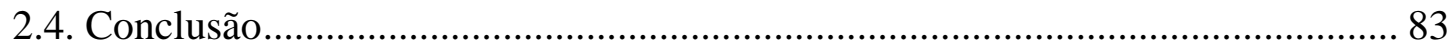

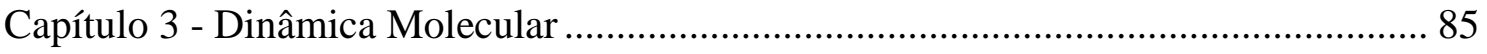

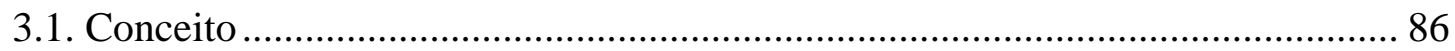

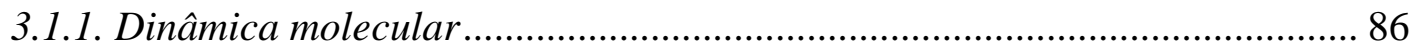

3.1.2. Somatório de Ewald para malha de partícula (PME) ................................. 91

3.1.3. Ressonância plasmônica de superfície (SPR) ............................................. 92

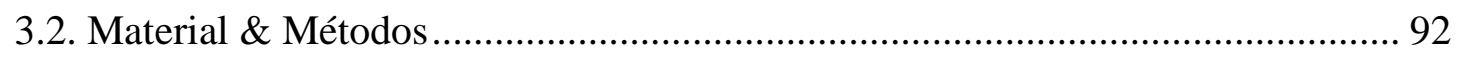

3.2.1. Rodando a simulação de dinâmica molecular ............................................ 92

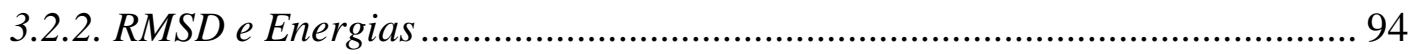

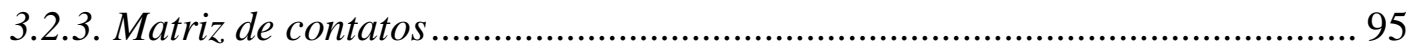

3.2.4. Análise de ligações de hidrogênio ............................................................... 95

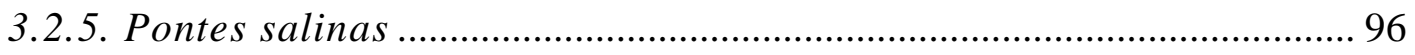

3.2.6. Ensaio in vitro utilizando ressonância plasmônica de superfície (SPR) ...... 96

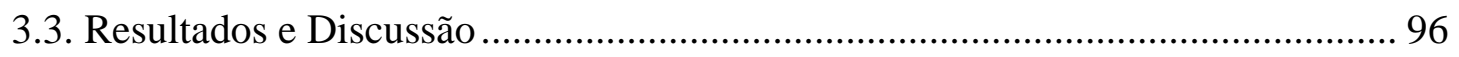

3.3.1. Quantificação do desvio da estrutura em comparação à referência ............ 98

3.3.2. Mapeamento de interações intermoleculares ........................................... 100

3.3.3 Integrando a matriz de contatos............................................................ 107

3.3.4. Cálculos de potenciais elétricos e pontes salinas ..................................... 115

3.3.5. Ensaio in vitro utilizando ressonância plasmônica de superfície (SPR) .... 117

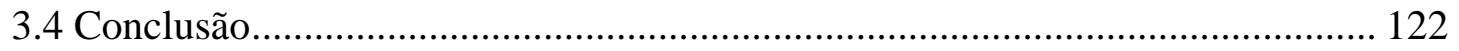

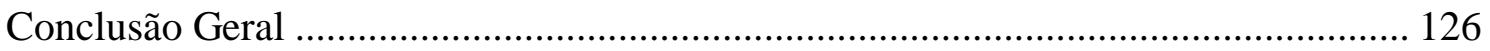

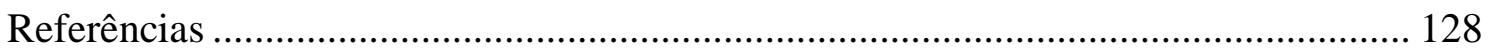

Anexos - Seção I - Material \& Métodos ..................................................................... 151

Anexos - Seção II - Artigos e Patentes Publicados ................................................... 164

Anexos - Seção III - Participações em Eventos Científicos \& Premiações................... 170 


\section{Introdução Geral}

O Bacillus thuringiensis (Bt) é uma bactéria entomopatogênica pertencente ao grupo Bacillus cereus, mas se distingue de outras espécies deste grupo por produzir, ao entrar em esporulação, inclusões cristalinas contendo predominantemente uma ou mais proteínas de ação inseticida (toxinas Cry e Cyt), também chamadas de $\delta$-endotoxinas (Hofte, H. \& Whiteley, H.R., 1989; Schnepf, E. et al., 1998). Schnepf e Whiteley provaram que os genes responsáveis pela formação dos cristais estavam contidos em grandes plasmídeos, o que abriu a possibilidade de inserir genes diretamente em plantas agronômicas (Schnepf, H.E. \& Whiteley, H.R., 1981). O primeiro relato de sucesso, neste sentido, foram com plantas de tomate (Fischhoff, D.A. et al., 1987) e tabacco (Vaeck, M. et al., 1987). Atualmente o Brasil aprova a comercialização de 37 plantas GM (geneticamente modificadas), das quais 19 expressam pelo menos uma toxina da família Cry1A. Esse dado deflagra a importância comercial das toxinas da família Cry1A e invocam para a necessidade de se compreender suas interações e seu mecanismo de ação em lavouras de cultivares transformadas com genes de Bt.

A subclasse Cry1 representa um grupo de proteínas que abrangem uma faixa de 120 a140 kDa de massa molecular, em sua forma proativa, e são primariamente tóxicas contra larvas de lepidópteros. Uma vez solubilizadas no ambiente alcalino intestinal, as protoxinas são ativadas por clivagens proteolíticas e processadas em uma toxina de aproximadamente $65 \mathrm{kDa}$. São proteínas pertencentes à família das 3D-Cry, onde todas são constituídas por três domínios bem definidos e contíguos. O domínio I apresenta significativa similaridade estrutural com o domínio formador-de-poro da $\alpha$-PFT colicina A. Por este motivo, o domínio I é considerado determinante no processo de penetração na membrana e formação de poro (Grochulski, P. et al., 1995). O domínio II, baseado nas variações de sequência, comprimento e estrutura de seus loops, é tido como o principal atuante no reconhecimento de receptores celulares do inseto-alvo, e, portanto, determinante na especificidade das toxinas 3D-Cry (Hofte, H. \& Whiteley, H.R., 1989; Ibrahim, M.A. et al., 2010). Já o domínio III possui estrutura semelhante aos domínios de ligação a carboidratos de outras proteínas, com os sítios de ligação a carboidratos localizados em duas fendas situadas no centro de cada folha- $\beta$ (de Maagd, R.A. et al., 2003). Por esses motivos, acredita-se que domínio III tenha função relacionada com o 
reconhecimento de receptores e inserção da toxina na membrana (de Maagd, R.A., Bravo, A. \& Crickmore, N., 2001).

Existem dois modelos que descrevem o mecanismo citotóxico das proteínas 3DCry e que, embora compartilhem as mesmas etapas iniciais, defendem diferentes causas para a morte celular: indução de apoptose ou formação de poro (causador de um desequilíbrio osmótico). Nas etapas comuns aos dois mecanismos, primeiramente as inclusões cristalinas são solubilizadas no intestino do inseto e as protoxinas vão sendo liberadas no lúmen. As protoxinas, por sua vez, são alvo de enzimas no intestino e têm suas extremidades $\mathrm{N}$ - e C-terminal clivadas. $\mathrm{O}$ resultado dessa ação enzimática é uma toxina ativa, contendo os três domínios característicos da família 3D-Cry, e capaz de reconhecer receptores específicos na membrana de células intestinais. Sugere-se que os domínios II e III sejam responsáveis pela ligação da toxina aos receptores tipo-caderina, Caderinas são proteínas filamentosas de membrana que participam do processo de adesão célula-célula, mas que no caso de muitos invertebrados podem servir como alvo primário para toxinas Cry. Por esse motivo, são designadas como os receptores primários de toxinas Cry, e sua interação com estas toxinas induzem mudanças conformacionais que permitem a clivagem $\mathrm{N}$-terminal da hélice $\alpha 1$ do domínio I.

Vários grupos de pesquisa têm concentrado esforços durante as últimas três décadas para elucidar o mecanismo de ação das $\delta$-endotoxinas no nível molecular. Neste sentido, a contribuição efetiva de cada domínio ou fragmento das toxinas, os eventos de mudança conformacional e as interações destas com a membrana intestinal, que ocorrem desde a ativação da protoxina até a morte celular, tem sido priorizados. $\mathrm{O}$ resultado deste esforço é uma vasta produção bibliográfica que versa sobre o tema com muitas evidências experimentais, obtidas por meio de diversas metodologias. Todavia, é importante observar que parte dos dados disponíveis na literatura está fora de sincronia, muitas vezes difíceis de serem comparados e não são conclusivos.

Tradicionalmente, o desenvolvimento de biopesticidas baseados em toxinas Cry tem dependido da amostragem de toxinas, com atividade para uma dada peste-alvo, utilizando isolados naturais de $B$. thuringiensis. Devido à sua importância agronômica como pesticida, há tempos almeja-se desenvolver um método para a engenharia de toxinas Cry com atividade inseticida aprimorada e que apresentem um menor espectro de pragas-alvo. Neste trabalho foi investigado o modo de ação pelo qual as toxinas Cry 
se ligam ao receptor primário do tipo caderina, BT- $\mathrm{R}_{1}$. Argumenta-se que a ligação a esse tipo de receptor é descrita como crucial para o desencadear de eventos que culminam na perda da $\alpha$-hélice 1 da toxina e subsequente morte celular. Adicionalmente, é nessa etapa que a especificidade da toxina ao inseto está mais claramente definida. 


\section{Capítulo 1}

\section{Introdução}

"Assim como casas são feitas de pedras, a ciência é feita de fatos. Mas uma pilha de pedras não é uma casa e uma coleção de fatos não é, necessariamente, ciência."

- Jules Henri Poincaré 


\section{1. Bacillus thuringiensis}

\subsubsection{Background}

O Bacillus thuringiensis $(\mathrm{Bt})$ é uma bactéria de solo Gram-positiva, anaeróbica facultativa e flagelada, que produz esporos sob certas restrições ou condições de estresse, como ausência de nutrientes e acúmulo de metabólitos indesejáveis. É caracterizada como patogênica a insetos e pertence ao grupo Bacillus cereus mas se distingue de outras espécies deste grupo (B. anthracis, B. cereus, B. mycoides, B. pseudomycoides e B. weihenstephanensis) por produzir, ao entrar em esporulação durante a fase estacionária de crescimento, inclusões cristalinas contendo predominantemente uma ou mais proteínas de ação inseticida (toxinas Cry e Cyt), também chamadas de $\delta$-endotoxinas (Figura 1)(Hofte, H. \& Whiteley, H.R., 1989; Schnepf, E. et al., 1998). Métodos moleculares como hibridização do DNA cromossômico, análise de ácidos graxos e fosfolipídios, comparação da sequência de 16S rRNA, entre outros, mostram que Bt, B. cereus e B. anthracis são, na verdade, uma mesma espécie. A peculiaridade é que o B. cereus pode se transformar em Bt ou $B$. anthracis ao receber plasmídeos que codificam as $\delta$-endotoxinas ou fatores de virulência (e.g. toxina letal pX01), respectivamente. Da mesma maneira, o Bt pode ocasionalmente perder a habilidade de formar cristais (produzir $\delta$-endotoxinas), tornando-se indistinguível do B. cereus (Aronson, A., 2002; Gonzalez, J.M., Jr., Brown, B.J. \& Carlton, B.C., 1982; Helgason, E. et al., 2000).

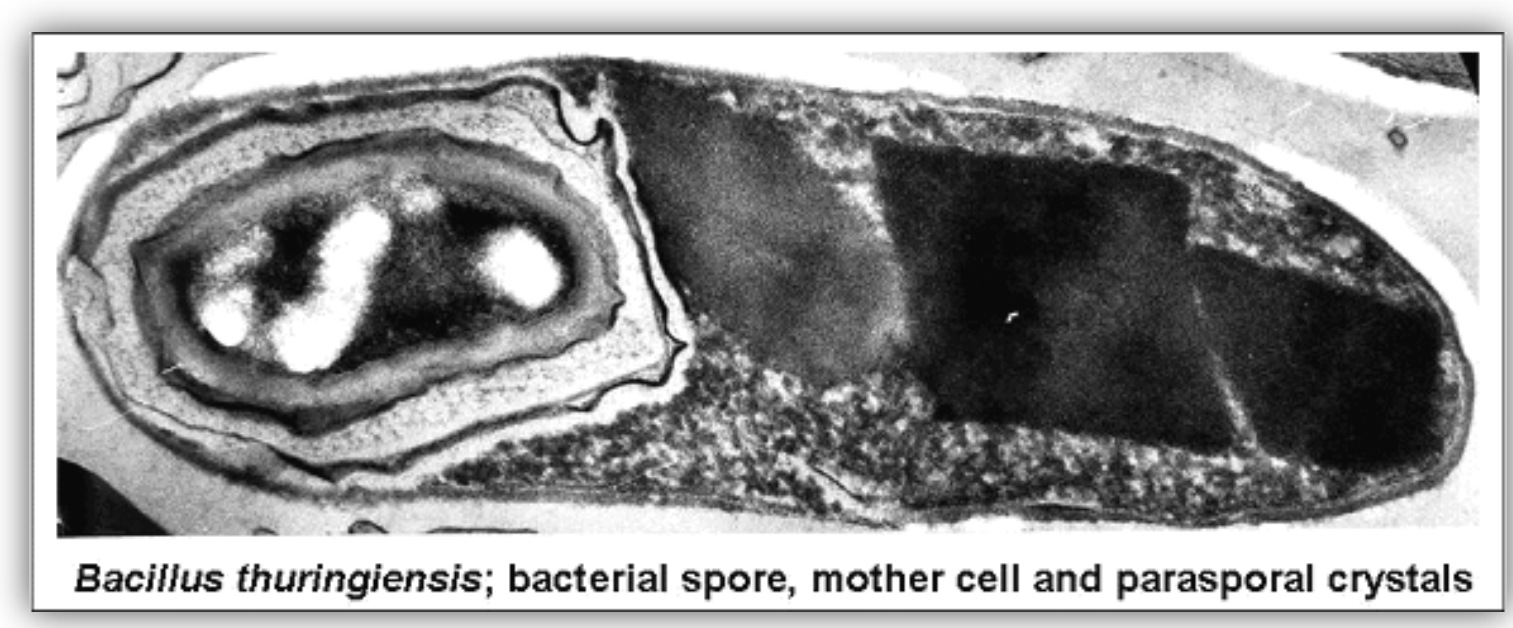

Figura 1: Célula de Bacillus thuringiensis em esporulação. O esporo possui estrutura oval e está localizado à esquerda. Inclusões cristalinas são as estruturas eletrodensas localizadas à direita. Imagem disponível no endereço eletrônico: (http://microgen.ouhsc.edu/b_thuring/b_thuringiensis_home.htm) 
O Bt é capaz de produzir também outros fatores de entomotoxicidade, como $\alpha-$ exotoxinas, $\beta$-exotoxinas, hemolisinas, enterotoxinas, quitinases, toxinas Vip e toxinas Sip, atuando ou não em sinergia com as $\delta$-endotoxinas (de Maagd, R.A. et al., 2003). Essas bactérias são ubíquas e encontradas nos mais diversos ambientes (Martin, P.A. \& Travers, R.S., 1989), mas principalmente na superfície de folhas e solos, sendo facilmente ingeridas na forma de esporos e inclusões cristalinas (contendo protoxinas) por insetos em alimentação. As inclusões são primeiramente solubilizadas no pH alcalino do intestino e após a ativação das protoxinas por proteases e o reconhecimento das toxinas ativas por receptores de membrana das células intestinais, o inseto hospedeiro adquire uma lesão - por meio de um mecanismo ainda controverso - e morre. No início desse processo, o conteúdo interno do inseto se mistura ao conteúdo do lúmen intestinal e proporciona nutrientes suficientes para permitir que os esporos dormentes germinem e a bactéria retorne ao crescimento vegetativo (Ibrahim, M.A. et al., 2010; Rajamohan, F., Lee, M.K. \& Dean, D.H., 1998; Sanahuja, G. et al., 2011).

Durante o estado vegetativo, outras toxinas são secretadas (e.g. toxinas Vip e Sip) e acabam agravando as lesões do hospedeiro (de Maagd, R.A. et al., 2003). Apesar disso, eventos epizoóticos de Bt em insetos são raros e seus esporos persistem por um longo tempo e podem até germinar em solos e plantas. Logo, o papel ecológico do Bt ainda está em debate e ele é melhor definido como um entomopatógeno facultativo (de Maagd, R.A. et al., 2003), embora seja sugerido que ele se reproduza principalmente em cadáveres de insetos (Raymond, B. et al., 2010).

\subsubsection{Histórico}

O Bt foi pela primeira vez descrito em 1901, por Shigetane Ishiwatari, e nomeado como Bacillus sotto em referencia à "doença de sotto", que deixava as larvas infectadas com aparência flácida. Posteriormente, em 1911, Ernst Berliner isolou este mesmo bacilo de uma mariposa Ephestia kuehniella e o nomeou Bacillus thuringiensis em homenagem à província de Thuringia (Alemanha), onde o primeiro inseto infectado foi encontrado por ele (Ibrahim, M.A. et al., 2010). Como a descrição feita por Ishiwatari foi breve e incompleta, a descrição e nome dado por Berliner foi aceito como o original (Milner, R.J., 1994). 
Apesar de Berliner ter provado que a ingestão repetida do bacilo era tóxica para insetos, culminando em morte, somente a partir de 1927 ele foi usado para controle biológico (Mattes, O., 1927). Mattes isolou novamente o Bt de Ephestia e este foi subsequentemente testado em campo no controle de Ostrinia nubilalis (Lepidoptera: Crambidae) (Husz, B., 1928). Este trabalho eventualmente levou ao surgimento do primeiro produto comercial: "Sporeine" foi produzido na França, em 1938, e aplicado no controle de diversas espécies de Lepidoptera. (Sanahuja, G. et al., 2011).

A história moderna do Bt começa na Califórnia, com o trabalho pioneiro de Steinhaus (Steinhaus, E.A., 1951). Ele cultivou a "cepa Mattes" em garrafas Povitsky contendo agar e nutrientes, coletou os esporos em meio aquoso e deixou-os secar em temperatura ambiente. Os esporos foram aplicados no controle da lagarta da alfafa e testados em nove campos desta cultivar. Com poucos dias, o experimento reproduziu os sintomas observados em laboratório e em sete campos a população da lagarta foi reduzida abaixo do nível economicamente viável.

Trabalhando no Canadá com B. sotto (do Japão), Angus foi o primeiro a mostrar que a toxicidade que levava à paralisia e morte do inseto estava associada aos cristais e que estes podiam ser ativados usando o suco gástrico do Bicho-da-seda (Bombyx mori)(Angus, T.A., 1954, 1956). Na mesma época, Hannay e Fitz-James resolveram a estrutura reticular das inclusões cristalinas usando microscopia eletrônica e determinaram que os cristais eram compostos por $17 \%$ de nitrogênio, continham 17 tipos de aminoácidos e representavam aproximadamente $30 \%$ do peso seco de culturas de Bt em esporulação (Figura 2.) (Hannay, C.L., 1953; Hannay, C.L. \& Fitz-James, P., 1955). 


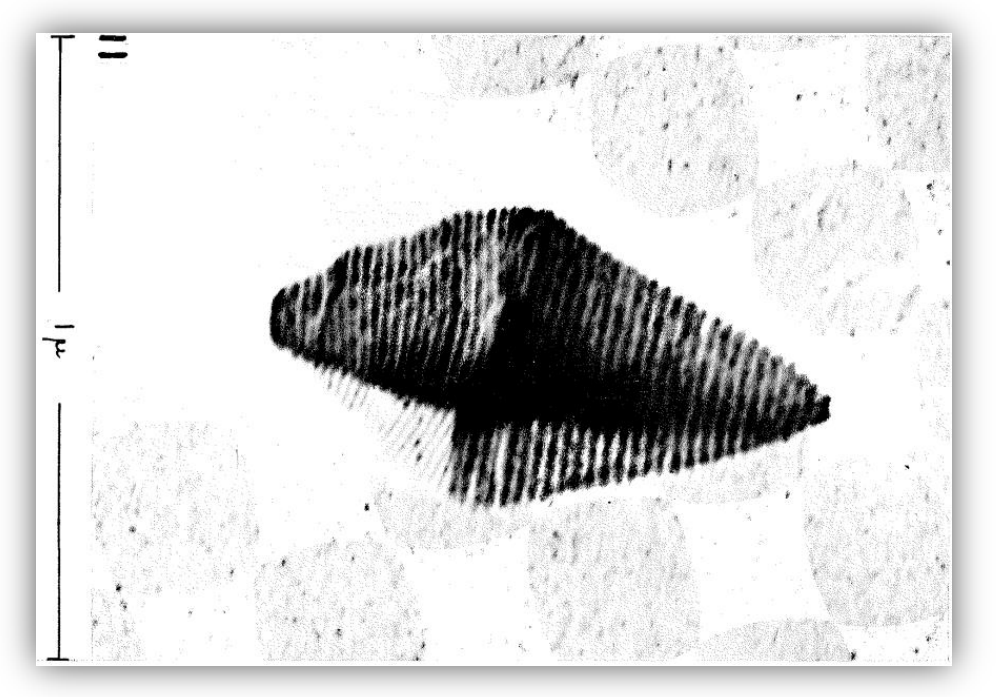

(Hannay, C.L. \& Fitz-James, P., 1955)

Figura 2: Microscopia eletrônica da superfície de uma inclusão cristalina. Imagem foi produzida através da manipulação do bombardeamento de elétrons.

Todos estes trabalhos estimularam o interesse comercial do Bt na década de 50, mas deficiências na formulação e na padronização dos produtos impossibilitaram a competição com os inseticidas químicos. Somente em 1967, em um artigo publicado com a participação de 31 colaboradores, foram detalhadas três preparações referência para bioensaios contra uma variedade de insetos-praga (Burges, H.D., 1967). Nesta mesma época, uma nova nomenclatura para o Bt e suas toxinas foi proposta, mas apenas o nome das toxinas vingariam até os dias de hoje. As toxinas presentes nas inclusões cristalinas foram designadas $\delta$-endotoxinas e o, até então, "fator mosca" foi designado $\beta$-exotoxina (mais tarde descobriram tratar-se de um potente inibidor de RNA polimerase em insetos, mamíferos e bactérias) (Heimpel, A.M., 1967; Heimpel, A.M. \& Angus, T.A., 1958).

Além da nova formulação e padronização, o isolamento de cepas mais potentes, primeiro em 1962, por Kurstak (var. kurstaki), e depois em 1967, por Dulmage (var. kurstaki HD1), impulsionaram a comercialização de biopesticidas à base de $\mathrm{Bt}$ (Dulmage, H.T., 1970; Dulmage, H.T. \& K., A., 1982). Em 1970, por exemplo, surgiu o produto DiPel, derivado do potente isolado HD1. Até hoje esse isolado é o ingrediente ativo de vários produtos de $\mathrm{Bt}$ vendidos para combater Lepidopteras (Tabela 1). Em 1976, alavancado pelo sucesso comercial de produtos à base de HD1, a busca por novos isolados culminou na descoberta do Bt var. israeliensis (Bti), altamente tóxico para 
Dípteros, e , em 1983, do Bt var. tenebrionis, tóxico para Coleópteros (Goldberg, L.J. \& Margalit, J., 1977; Krieg, A. et al., 1983). Os produtos baseados em cepas naturais de Bt estão listados na Tabela 1 .

\begin{tabular}{lll}
\hline Trade name & Subspecies and strain & Target insect \\
\hline Biobit & Bt kurstaki HD-1 & Lepidoptera \\
Dipel & Bt kurstaki HD-1 & Lepidoptera \\
Florbac & Bt aizawai & Lepidoptera \\
Costar & Bt kurstaki SA-12 & Lepidoptera \\
Delfin & Bt kurstaki SA-11 & Lepidoptera \\
Thuricide & Bt kurstaki HD-1 & Lepidoptera \\
Tekar & Bt israeliensis & Diptera \\
Javelin & Bt kurstaki SA-11 & Lepidoptera \\
Bactimos & Bt israliensis & Diptera \\
Vectolex GC & Bacillus sphaericus & Diptera \\
Bactospeine & Bt kurstaki HD-1 & Lepidoptera \\
Acrobe & Bt israliensis & Diptera \\
Novodor & Bt tenebrionis & Coleoptera \\
Trident & Bt tenebrionis & Coleoptera \\
\hline
\end{tabular}

Tabela 1: Produtos baseados em cepas naturais de Bt e seus alvos (Kaur, S., 2000). Bt kurstaki HD12 foi renomeado para SA-11. B. sphaericus é hoje conhecido como Lysinibacillus sphaericus. Fonte: (Sanahuja, G. et al., 2011).

Atualmente, a busca por novas cepas é feita por meio de PCR, uma vez que esta técnica permite verificar a assinatura específica de certas toxinas, bem como verificar se o aumento na toxicidade é devido a um aumento no nível de expressão e/ou pela presença de uma nova toxina (Kuo, W.S. \& Chak, K.F., 1996; Porcar, M. \& JuarezPerez, V., 2003). Outra alternativa é criar novas cepas de Bt que carregam diferentes combinações de toxinas. Assim, é possível aumentar o alcance de pestes-alvo suscetíveis à uma dada cepa e aumentar sua toxicidade à uma espécie ou ordem de inseto (Tabela 2). Esse processo pode ser feito por conjugação ou por transformação direta, e ajudou na comercialização de vários biopesticidas (Arantes, O. \& Lereclus, D., 1991; Gonzalez, J.M., Jr., Brown, B.J. \& Carlton, B.C., 1982; Kronstad, J.W., Schnepf, H.E. \& Whiteley, H.R., 1983). Em 2011 haviam 28 biopesticidas à base de Bt no mercado mundial, todos eficientes e amplamente utilizados (Sanahuja, G. et al., 2011). 


\begin{tabular}{|c|c|c|}
\hline Product & Strain/genes & Insert order \\
\hline \multicolumn{3}{|c|}{ Transconjugant strains } \\
\hline Agree & aizawai & Lepidoptera \\
\hline Condor & kurstaki & Lepidoptera \\
\hline Cutlass & kurstaki & Lepidoptera \\
\hline Design & aizawai & Lepidoptera \\
\hline Foil & kurstaki & Lepidoptera/Coleoptera \\
\hline \multicolumn{3}{|c|}{ Recombinant strains } \\
\hline \multirow[t]{2}{*}{ Raven } & Cry1Ac (x2), Cry3A & Lepidoptera \\
\hline & Cry3Bb (imported) & \\
\hline \multirow[t]{2}{*}{ CRYMAX } & Cry1Ac (x3), Cry2A & Lepidoptera \\
\hline & Cry1C (imported) & \\
\hline \multirow[t]{2}{*}{ Lepinox } & Cry1Aa, Cry1Ac (x2), Cry2A & Lepidoptera \\
\hline & Cry1F-1Ac (imported) & \\
\hline
\end{tabular}

Tabela 2: Produtos de Bt baseados em conjugação e recombinação. (Sanahuja, G. et al., 2011)

Um ano após o lançamento de biopesticidas à base de Bti, Schnepf e Whiteley usaram clonagem em Escherichia coli para provar que os genes responsáveis pela formação de cristais estão contidos em grandes plasmídeos (Gonzalez, J.M., Jr., Dulmage, H.T. \& Carlton, B.C., 1981; Schnepf, H.E. \& Whiteley, H.R., 1981), que variam de 4,56 a $228 \mathrm{~Kb}$ (Baum, J.A. \& Gonzalez, J.M., Jr., 1992). Além de formar os cristais contendo toxinas, a bactéria transformada se tornou tóxica à Manduca sexta. Este trabalho abriu a possibilidade de inserir genes diretamente em plantas agronômicas, de maneira que as folhas se tornassem tóxicas para as lagartas. Os primeiros relato de sucesso, neste sentido, foram com plantas de tomate (Fischhoff, D.A. et al., 1987) e tabacco (Vaeck, M. et al., 1987).

\subsubsection{Agricultura Bt}

Embora os biopesticidas à base de Bt apresentem vantagens como segurança, especificidade, potência e biodegradação, a possibilidade de inserir os genes das toxinas em plantas provou ser um grande advento. Usualmente, o biopesticida é aplicado quando larvas de primeiro instar estão presentes, pois larvas em estágio mais avançado se mostram mais tolerantes. No entanto, o spray de Bt só é efetivo quando presente nos órgãos de plantas onde as larvas se alimentam. O problema é que os sprays persistem por poucos dias na superfície da folha, uma vez que a luz UV, o clima, o ambiente químico da superfície foliar e a presença de proteinases contribuem para a degradação 
das toxinas Cry. Além disso, muitos esporos são "lavados" da superfície foliar devido à chuva e ao vento. As vantagens e desvantagens do uso de sprays de Bt estão listados na Tabela 3.

\begin{tabular}{ll}
\hline Advantages & Disadvantages \\
\hline $\begin{array}{l}\text { Potent insecticidal activity } \\
\text { Specific host range }\end{array}$ & $\begin{array}{c}\text { Rapidly inactivated by UV light, } \\
\text { heat and extreme } \mathrm{pH}\end{array}$ \\
$\begin{array}{l}\text { Harmless to humans and } \\
\text { Susceptible to proteases in leaf exudates } \\
\text { other mammals }\end{array}$ & $\begin{array}{l}\text { Easily removed from plant surface } \\
\text { biodegradable }\end{array}$ \\
& Therefore needs to be reapplied for full effect
\end{tabular}

Tabela 3: Vantagens e desvantagens do uso de sprays de Bt. (Sanahuja, G. et al., 2011)

Por causa da susceptibilidade à climas rigorosos e da estreita janela de eficácia, os sprays de Bt devem ser reaplicados várias vezes durante uma safra para que atinjam toda a população de larvas. Esse processo aumenta o numero de aplicações dos sprays na lavoura e a quantidade de combustível necessário para disseminá-lo na lavoura, elevando os custos da agricultura (Sanahuja, G. et al., 2011). Igualmente problemático é o fato de que os sprays causam pouco impacto a pestes endofíticas (que se alimentam de tecidos internos da planta) e pestes que se alimentam próximo às raízes.

O surgimento das primeiras plantas transformadas com gene cry gerou um grande interesse comercial na década de 80 , pois prometiam solucionar todos esses problemas. O potencial comercial, no entanto, só foi confirmado alguns anos depois com a otimização dos genes cry sintéticos. Dentre os aprimoramentos, podemos destacar: o aumento no conteúdo de guanidina e citidina ( $\mathrm{G}$ e C); a troca para o códonusage de plantas; o uso de promotores mais potentes; uma poliadenilação e sinal de terminação mais eficiente; a inserção de introns heterólogos nos vetores de expressão; e a introdução dos genes cry no genoma de cloroplastos (Koziel, M.G. et al., 1993; McBride, K.E. et al., 1995; Perlak, F.J. et al., 1991).

O primeiro sucesso comercial de uma "cultivar Bt" aconteceu com a chegada ao mercado de uma batata transgênica resistente ao besoura-da-batata (Leptinotarsa decemlineata), em 1995. As batatas "NewLeaf", da Monsanto, expressavam a toxina Cry3A do Bt var. tenebrionis e se mostraram muito mais eficiente na lavoura que os sprays biopesticidas derivados desta mesma cepa (Novodor e Trident) (Perlak, F.J. et 
al., 1993). Logo em seguida chegaram ao mercado os milhos Bt "KnockOut", da Syngenta, e "NatureGuard", da Mycogen. Ambos expressam Cry1Ab e conferem resistência à broca-do-milho (Ostrinia nubilalis). As primeiras cultivares de algodão Bt a chegar no mercado foram o "Bollgard" e "Inguard, ambos da Monsanto, que expressavam a toxina Cry1Ac. Outras cultivares Bt foram desenvolvidas logo em seguida e logo estabeleceu-se o primeiro panorama da indústria biotecnológica de lavouras (Sanahuja, G. et al., 2011).

É importante destacar que várias cultivares Bt expressando toxinas da família Cry1A consolidaram espaço no mercado desde esse primeiro cenário. Podemos destacar as cultivares "Bollgard II" (2002), "YieldGard" (2002) e "YieldGard Plus" (2003). O que se viu daí em diante foi um mercado turbulento, com empresas de grande e pequeno porte usando-se de diversificadas manobras para adquirir patentes estratégicas e tecnologias (Sanahuja, G. et al., 2011). O atual status comercial de diferentes cultivares $\mathrm{Bt}$, bem como as toxinas que elas expressam e as empresas envolvidas em sua comercialização, pode ser visto no endereço eletrônico do Centro para Avaliação de Risco Ambiental (CERA): http://cera-gmc.org/GMCropDatabase.

Atualmente o Brasil aprova a comercialização de 37 plantas geneticamente modificadas (GM). Elas possuem tolerância à herbicidas ou resistência à insetos ou vírus. Considerando todas as modificações, 24 são geneticamente modificadas para apresentar resistência à insetos-praga. Deste grupo, 23 expressam toxinas Cry e 19 expressam pelo menos uma toxina da família Cry1A. Estes dados podem ser obtidos no endereço eletrônico da Comissão Técnica Nacional de Biossegurança (CTNBio): http://www.ctnbio.gov.br. Esse dado deflagra a importância comercial das toxinas da família Cry1A e invocam para a necessidade de se compreender suas interações e seu mecanismo de ação em lavouras Bt.

\subsubsection{Biossegurança, Meio Ambiente e Economia}

As toxinas Cry se tornaram biopesticidas comercialmente viáveis devido à sua alta seletividade a insetos-alvo, segurança para humanos, vertebrados, e plantas, e porque são biodegradáveis (Schnepf, E. et al., 1998)

Embora haja um grande debate, tanto político quanto público, em relação ao impacto ambiental causado por cultivares geneticamente modificadas, está claro que as 
cultivares Bt proveram imensos benefícios ao meio ambiente. O desenvolvimento de cultivares Bt reduziu o uso de pesticidas, bem como economizou indiretamente o combustível fóssil utilizado para sua disseminação, reduziu a emissão de $\mathrm{CO}_{2}$ gerado por práticas agrícolas, e conservou o solo e umidade por encorajar uma agricultura de plantio direto, onde restos vegetais de outras culturas são mantidos na superfície do solo e garantem cobertura e proteção do mesmo contra processos danosos (Sanahuja, G. et al., 2011). A redução acumulada de pesticidas entre o período de 1996 a 2012 foi de aproximadamente 503 mil toneladas $(-8,8 \%)$, o que equivale a $18,7 \%$ de redução liquida do impacto ambiental associado à herbicidas e inseticidas medido pelo quociente de impacto ambiental (EIQ) (http://www.pgeconomics.co.uk/). Os dados correspondentes apenas a 2008 revelam a redução de 34600 toneladas de pesticidas $(9,6 \%)$ e redução de 18,2\% no EIQ (Brookes, G. \& Barfoot, P., 2014). Em países como Índia, China, Brasil e Argentina, que adotam o uso da agricultura $\mathrm{Bt}$, a quantidade de aplicações de pesticidas por lavoura reduziu de 16 para 2-3, o que consequentemente diminuiu o envenenamento por exposição química. Devido à redução de danos causado por pragas, o rendimento liquido de milho e algodão $\mathrm{Bt}$ resistentes à insetos aumentou em média $10,4 \%$ e 16,1\%, respectivamente, durante o período de 1996 a 2012(Brookes, G. \& Barfoot, P., 2014). Em 2012, a redução da emissão de gases de efeito estufa devido à redução de combustível e maior armazenamento de carbono no solo foi o equivalente a retirar 27 milhões de tonelada de $\mathrm{CO}_{2}$ da atmosfera, o que se equipara a retirar 11,9 milhões de carros das ruas por um ano(Brookes, G. \& Barfoot, P., 2014).

Apesar da redução no uso de pesticida ter acarretado em benefícios econômicos e ambientais, existe a preocupação de que cultivares Bt possam afetar insetos benéficos (aqueles que promovem polinização ou controlam insetos pestes), desequilibrar o ecossistema e desencadear a reprodução de pestes secundárias. Estudos de campo com a batata NewLeaf (Cry3Aa) mostraram que a toxina afeta especificamente o besouro-dabatata e não causa efeitos deletérios a outros insetos na lavoura de batatas, inclusive ao seu predador natural. Já os sprays químicos causaram a morte do besouro e de seu predador, gerando uma explosão na população de insetos vetores que carregam patógenos virais (Reed, G.L. et al., 2001). No caso de estudo com milho Bt, a população do predador e da presa alternativa se adaptaram para refletir a ausência da peste alvo (Faria, C.A. et al., 2007). Em algodão, a toxina não teve efeitos na população de Aphis gossypii (um inseto benéfico) e também não foi detectada no néctar, que serve de 
energia para várias espécies de artrópodes incluindo predadores e parasitoides. Portanto, o algodão Bt não tem impacto negativo em insetos benéficos do ecossistema do algodão (Lawo, N.C., Wackers, F.L. \& Romeis, J., 2009).

Peste secundária é aquela que é mantida em cheque pela presença da peste primária, de maneira que a eliminação da peste primária pode elevar a peste secundária ao status de primária, podendo inclusive afetar outras lavoura vizinhas que não eram incomodadas por nenhuma das pestes (Sanahuja, G. et al., 2011). O bicudo-doalgodeiro é a peste primária do algodão e suprime a população de homópteras que se alimentam da seiva do algodão. O algodão Bt representa $95 \%$ do algodão no norte da China e é letal para a larva de bicudo-do-algodeiro. Um estudo avaliando os impactos na população de homópteras mostrou que houve um aumento anual da população de 1997 a 2008, fazendo-a alcançar o status de peste primária e causando danos a diversas outras cultivares não relacionadas. Já as lavouras não transgênicas de algodão não foram afetadas porque as espécies de homópteras acabam sendo controladas por pesticidas de largo-espectro que também são aplicados para o controle de larvas da mariposa Pectinophora gossypiella (Lu, Y.H. et al., 2010). Apesar desse efeito indesejado, ele acaba sendo balanceado pelo aumento na biodiversidade de insetos observados em lavouras de algodão Bt: 31 espécies em plantios Bt (23 benéficas) comparado a 14 espécies em plantios não transgênicos (5 benéficas) (Pray, C.E. et al., 2002).

Em adição à população de insetos, é útil estudar os impactos de Bt em outras partes do ecossistema, particularmente no solo que é a destinação final dos esporos e toxinas de Bt após serem lavados da superfície vegetal, exalados de raízes ou lançado de grãos de pólen. Minhocas são um bom indicador para a saúde geral do solo e em comparações do número de minhocas em plantios de milho não transgênicos e milho Bt expressando Cry1 Ab por quatro anos não houve diferença no desenvolvimento ou biomassa de minhocas (Zeilinger, A.R. et al., 2010).

A Agência de Proteção Ambiental dos Estados Unidos registrou 177 produtos à base de Bt entre 1961 e 1995. Numerosos estudos de laboratório demonstraram que Bt e seus produtos não são infecciosos e são tóxicos para humanos apenas em quantidades $\geq 10^{11}$ unidades formadoras de colônia (cfu). Há apenas dois relatos de infecção em humanos, e nesses casos ou o indivíduo havia sofrido queimaduras ou sofrido uma lesão por explosão, o que os predispôs a uma infecção. Em dois estudos epidemiológicos 
conduzidos durante a aplicação aérea em larga escala de sprays Bt não foi reportada nenhuma evidência de doença. Da mesma forma, não houve evidência de injúria em ratos ou ovelhas alimentados com produto $\mathrm{Bt}$, bem como estudos epidemiológicos não detectaram aumento de diarreia durante campanhas de aplicação aérea dos sprays. Baseado em estudos de laboratório e campo, os inseticidas de Bt tem um excelente registro de segurança (Siegel, J.P., 2001).

Um estudo feito com 48,901 produtos de comida pronta do mercado de varejo dinamarquês mostrou que 0,5\% deles continham bactérias do grupo Bacillus cereus em quantidades acima de $10^{4} \mathrm{cfu} \cdot \mathrm{g}^{-1}$. A maior frequência ocorreu em produtos amiláceos cozinhados, mas também em tomates e pepinos frescos. Quarenta cepas selecionadas aleatoriamente continham pelo menos um gene ou componente envolvido com doença diarreica humana, enquanto toxina emética (causadora de vômito) foi relatada em apenas uma cepa de $B$. cereus. O interessante é que 31 dessas bactérias selecionadas aleatoriamente podiam ser classificadas como $\mathrm{Bt}$, pois produziam inclusões cristalinas contendo toxinas Cry.

Portanto, uma grande proporção dos organismos presentes em comidas podem pertencer a espécie Bt (Rosenquist, H. et al., 2005). No ano seguinte a esse estudo, 128 cepas de bactérias da família $B$. cereus foram isoladas de frutas e vegetais frescos à venda no mercado de varejo da Dinamarca. Um total de 50 (39\%) dessas cepas pôde ser classificada como Bt. Análises do DNA plasmidial identificaram que 23 das 50 cepas eram subtipos de Bt utilizados em biopesticidas comerciais e, em alguns casos, indistinguíveis das cepas contidas nesses produtos. Além disso foi verificado a presença de enterotoxina em várias dessas cepas comerciais. Esse estudo indica que resíduos de inseticidas à base de Bt podem ser encontrados em frutas e vegetais frescos e que estes são potencialmente enterotóxicos (Frederiksen, K. et al., 2006). Um fato curioso é que os locais mais investigados na busca de novas cepas de Bt com alto potencial inseticida são justamente os armazéns de grãos. Esses locais abrigam populações de $\mathrm{Bt}$ em abundância e explicam a presença dessa bactéria em produtos de varejo. É provável que o seres humanos estejam consumindo alimentos contaminados com Bt desde que a humanidade começou a estocar grãos, o que estima-se que iniciou com trigo cerca de 8000 mil anos atrás. 
Os primeiros 100 anos de sprays inseticidas e 20 anos de lavouras transgênicas à base de Bt foram extraordinariamente bem sucedidos e vantajosos, com um longo registro de segurança, eficácia e benefícios ao meio ambiente. Por esses motivos, continua-se o trabalho de identificar e criar cepas e toxinas de Bt mais potentes e específicas, bem como de gerar linhagens de plantas transgênicas que suprimam os danos causados por pestes e reduzam o surgimento de espécies resistentes, sem conferir danos a espécies benéficas e organismos do solo.

\subsubsection{Toxinas de Bt}

\section{$\underline{\text { Nomenclatura e Organização }}$}

Em 1989 foi estabelecido um comitê para organizar a nomenclatura das toxinas de $\mathrm{Bt}$, que surgiam em número crescente a cada ano (Hofte, H. \& Whiteley, H.R., 1989). Posteriormente, foi elaborada uma revisão completa dessa nomenclatura (Crickmore, N. et al., 1998) e em 2014 o comitê elaborou um endereço eletrônico que compila todas as toxinas já descritas e a relação filogenética entre elas (http://www.btnomenclature.info) (Crickmore, N. et al., 2014). Ficou estabelecido que os genes das toxinas sejam escritos em minúsculo e itálico (e.g. cry, cyt, vip ou sip) e que o nome das toxinas sejam organizados em quatro categorias baseadas no grau de identidade a toxinas previamente nomeadas. O agrupamento por esse critério não implica em "similaridade de estrutura", modo de ação ou alvos suscetíveis. Um algarismo arábico é designado para a primeira e quarta categoria, e uma letra maiúscula e minúscula são designadas para a segunda e terceira categorias, respectivamente (Figura 3).

As toxinas Cry são classificadas de acordo com a similaridade de sequência dos resíduos de aminoácidos de suas protoxinas (Bravo, A. et al., 2013). Dessa maneira, proteínas compartilhando menos de $45 \%$ de identidade (de aminoácidos) são atribuídas categorias primárias diferentes (um algarismo arábico, e.g., Cry1 e Cry2); duas proteínas compartilhando menos de $78 \%$ de identidade são atribuídas categorias secundárias diferentes (uma letra maiúscula, e.g., Cry1A e Cry1C); proteínas compartilhando menos de $95 \%$ de identidade são atribuídas categorias terciárias diferentes (uma letra minúscula, e.g., Cry1Aa e Cry1 Ab); e, finalmente, para diferenciar proteínas compartilhando mais de $95 \%$ de identidade, a quarta categoria é atribuída (um 
algarismo arábico, e.g., Cry1Aa1 e Cry1Aa2)(Crickmore, N. et al., 1998; Hofte, H. \& Whiteley, H.R., 1989).

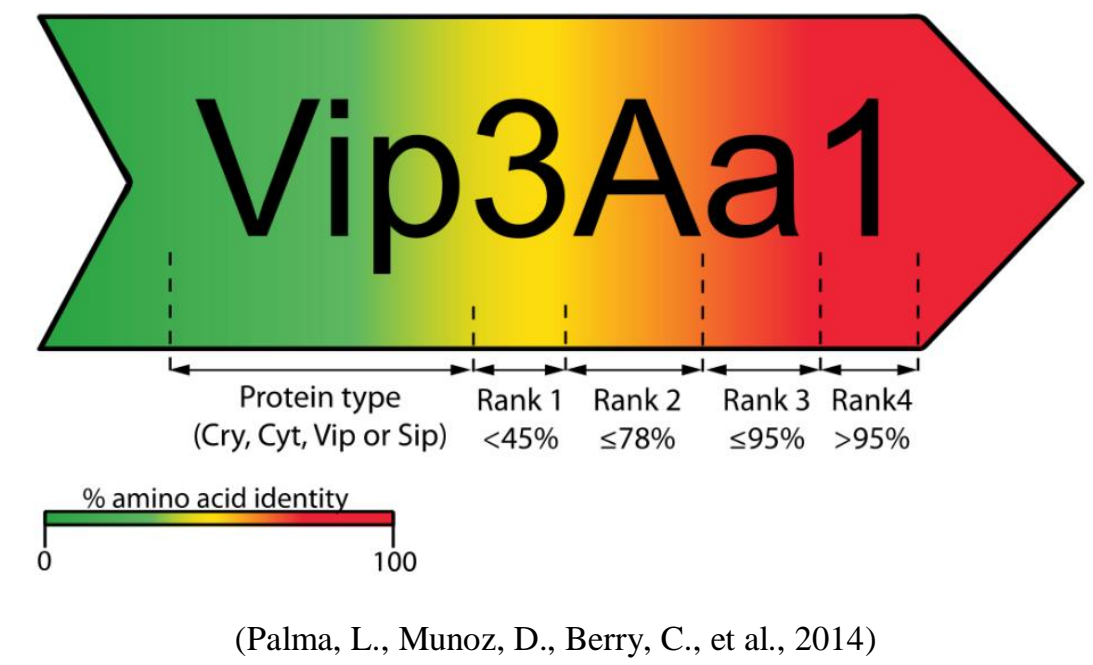

Figura 3: Esquema ilustrativo da nomenclatura das toxinas de Bt. Quatro categorias são atribuídas ao nome de uma nova toxina, de acordo com o grau de identidade de aminoácidos.

$\mathrm{O} \mathrm{Bt}$ produz toxinas em dois momentos distintos: durante o crescimento vegetativo; e durante a esporulação, na fase estacionária. As toxinas produzidas durante o crescimento vegetativo são secretadas para a matriz extracelular (Vip e Sip), enquanto as toxinas produzidas durante a esporulação são incorporadas dentro de inclusões cristalinas (Cyt e Cry) que precisam ser solubilizadas. Para melhor compreender as toxinas de Bt, podemos separá-las em grupos homólogos, ou famílias. Enquanto as toxinas Cyt, Vip e Sip são famílias bem definidas, as toxinas Cry não pertencem a um único grupo homólogo mas, em contrapartida, incluem um número de famílias não relacionadas (Palma, L., Munoz, D., Berry, C., et al., 2014).

\section{$\underline{\text { Toxinas Cristais }}$}

O maior subgrupo de toxinas Cry é composto pelas proteínas Cry de três domínios (3D-Cry)(Figura 4), ao passo que as outras toxinas Cry pertencem à família ETX_MTX2-like, similares às toxinas épsilon (ETX) de Clostridium e toxinas mosquitocidas (MTX) de Lysinbacillus sphaericus (Ls), e à família Toxina_10 (Binlike), similares às toxinas binárias de Ls (Gonzalez, M.R. et al., 2008; Kelker, M.S. et al., 2014; Popoff, M.R., 2011; Srisucharitpanit, K. et al., 2014). 


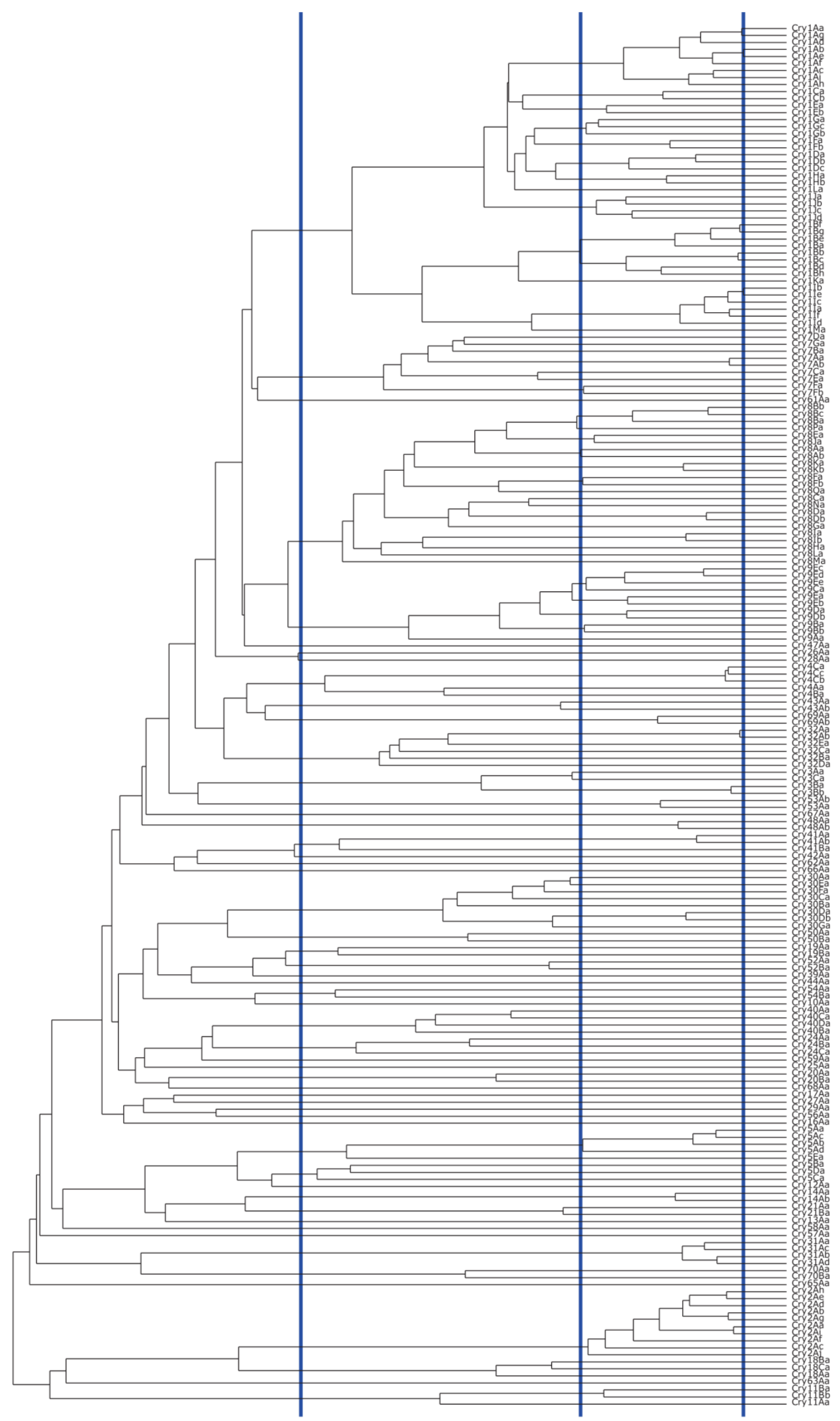

Figura 4: Árvore filogenética das toxinas Cry e a organização por categorias. (Crickmore, N. et al., 2014) 
Tanto a família ETX_MTX2 como a Toxina_10 possuem algumas características estruturais da família de Aerolisinas, mas apenas a toxina Cry34 é considerada pertencer a esta família. O interessante é que a interação da toxina Cry34 com a Cry35, embora não possuam homologia evidente considerando a sequência de aminoácidos, apresenta uma notável similaridade estrutural com outra toxina binária, a Cry23/Cry37 (de Maagd, R.A. et al., 2003). Em 2014, as estruturas cristalográficas de Cry34 e Cry35 foram resolvidas e suas propriedades biofísicas caracterizadas (Kelker, M.S. et al., 2014). As toxinas Cry6, Cry22 e Cry55 ainda não possuem uma família caracterizada (Palma, L., Munoz, D., Berry, C., et al., 2014; Yu, Z. et al., 2014).

O Bt produz também algumas toxinas sem atividade inseticida. Essas toxinas Cry não-inseticidas podem receber a designação Cry ou Parasporina (Ps) e pertencer às famílias ETX_MTX2 ou 3D-Cry (Figura 5). No entanto, as parasporinas ganharam uma importância maior por apresentarem, como diferencial, toxicidade preferencial à células cancerígenas de mamíferos (Ohba, M., Mizuki, E. \& Uemori, A., 2009). Essa característica e o número crescente de novos membros as tornaram únicas e as alçaram à uma nova categoria. Em 2006 foi instituído um comitê para classificação e nomenclatura de parasporinas (http://parasporin.fitc.pref.fukuoka.jp) e ficou estabelecido que o termo "parasporina" seja atribuído para qualquer proteína parasporal de $\mathrm{Bt}$, ou bactéria relacionada, que não apresente atividade hemolítica mas seja capaz de matar preferencialmente células cancerígenas (Ohba, M., Mizuki, E. \& Uemori, A., 2009; Xu, C. et al., 2014). Já existem duas estruturas obtidas por cristalografia de raio-X referentes às parasporinas (Akiba, T. et al., 2009; Akiba, T. et al., 2006) depositadas no Banco de Dados de Proteínas (PDB) (Berman, H.M., Bhat, T.N., et al., 2000). A Figura 5 e 7 ilustram a organização e relações entre toxinas de Bt. 


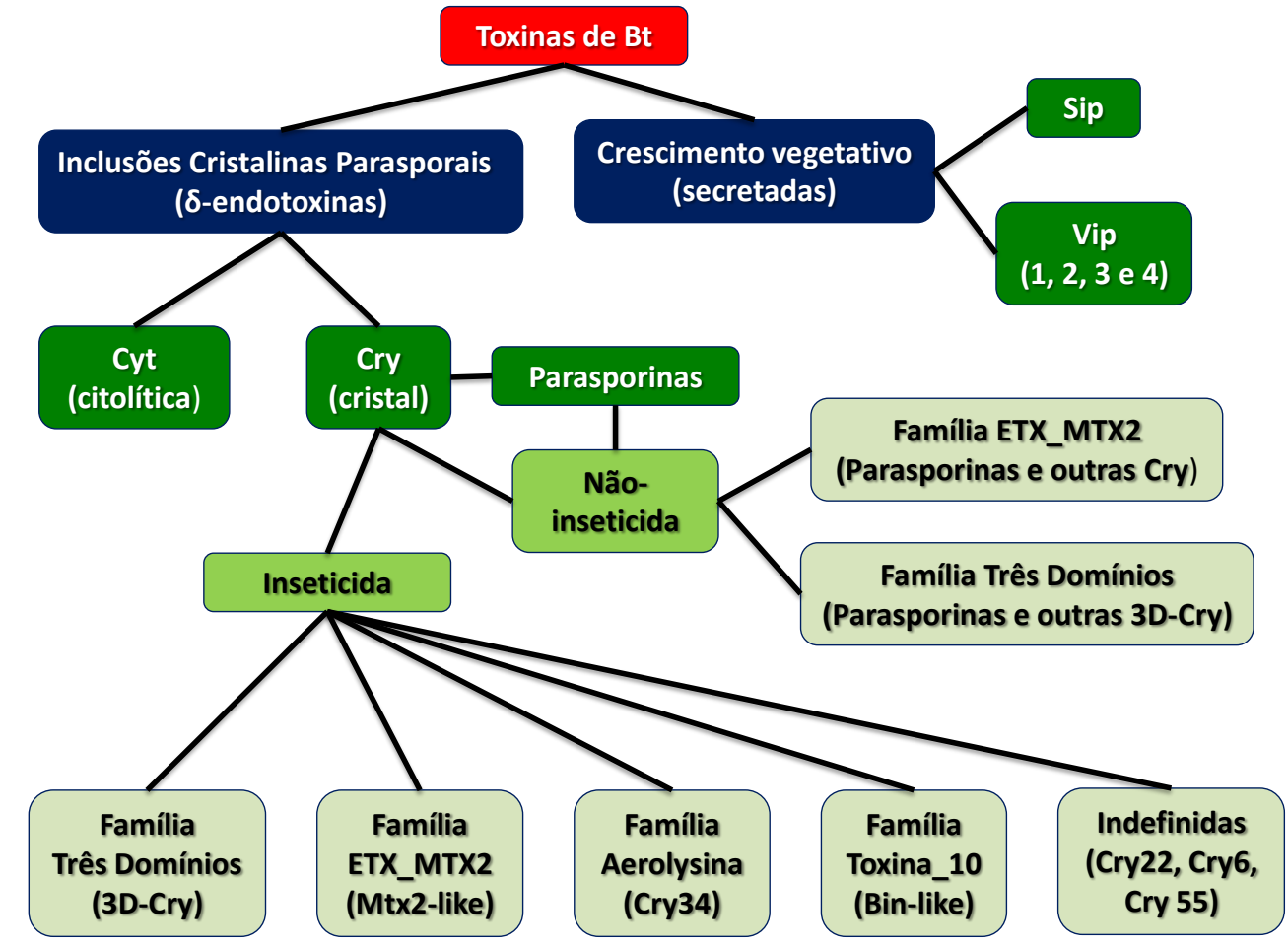

Figura 5: Organograma ilustrando a divisão de grupos e famílias das toxinas produzidas por Bt. As toxinas são primeiramente divididas em $\delta$-endotoxinas e toxinas secretadas. Depois elas podem receber as designações Cry, Cyt, Parasporina, Vip ou Sip. Por fim, as toxinas são enquadradas em famílias apresentando similaridades estruturais.

As toxinas Cyt constituem um grupo menor e distinto de proteínas cristalinas que apresentam atividade citolítica contra algumas larvas de dípteros, particularmente mosquitos e moscas pretas (Simuliidae) (Ben-Dov, E., 2014; Bravo, A., Gill, S.S. \& Soberon, M., 2007; Butko, P., 2003; Cohen, S. et al., 2011; Soberon, M., Lopez-Diaz, J.A. \& Bravo, A., 2013). Além disso, algumas toxinas Cyt agem em sinergia com outras toxinas de Bt e aumentam sua atividade inseticida, podendo inclusive atuar como um receptor e suprimir resistências de insetos (Perez, C. et al., 2005; Soberon, M., LopezDiaz, J.A. \& Bravo, A., 2013; Yu, X. et al., 2012; Zhang, B. et al., 2006). Até o presente, duas estruturas cristalográficas de toxinas Cyt (Cohen, S. et al., 2011; Cohen, S. et al., 2008) foram depositadas no PDB (www.rcsb.org) (Berman, H.M., Westbrook, J., et al., 2000) e o Comitê para Nomenclatura de Toxinas Bt classificam as toxinas Cyt em três categorias primárias: Cyt1, Cyt2 e Cyt3 (Crickmore, N. et al., 2014). Dois mecanismos de ação foram propostos para essas toxinas, onde um sugere a formação de poros e o outro um mecanismo de ação detergente menos específico (Butko, P., 2003; Soberon, M., Lopez-Diaz, J.A. \& Bravo, A., 2013). Para toxinas como Cyt1A, com 
estrutura tridimensional típica de citolisina e um padrão hemolítico específico, que difere de detergentes iônicos e não iônicos, o mecanismo de formação de poros é o melhor aceito (Cohen, S. et al., 2011).

\section{$\underline{\text { Toxinas Secretadas }}$}

As proteínas inseticidas secretadas por Bt durante o crescimento vegetativo constituem duas classes, e foram designadas como "proteínas inseticidas vegetativas" (Vip) (Estruch, J.J. et al., 1996) e "proteínas inseticidas secretadas" (Sip) (Donovan, W.P. et al., 2006). Até o momento, o Comitê para Nomenclatura de Toxinas Bt identificou e classificou as toxinas Vip em quatro famílias diferentes, i.e., Vip1, Vip2, Vip3 e a recém identificada Vip4 (Crickmore, N. et al., 2014). Proteínas secretáveis, como a Vip1, Vip2 e Sip, contém sequências conservadas de peptídeo sinal que são comumente clivadas antes ou depois do processo de secreção (Donovan, W.P. et al., 2006; Shi, Y. et al., 2007; Shi, Y. et al., 2004). Vip1 e Vip2 constituem uma toxina binária com alta atividade inseticida contra algumas pestes de coleópteros (Bi, Y. et al., 2015), assim como Sip (Donovan, W.P. et al., 2006), e contra a peste Aphis gossypii (Hemíptera)(Figura 6)(Sattar, S. \& Maiti, M.K., 2011). Em contraste, as toxinas da família Vip3 são cadeia simples (não binárias), não contém peptídeo sinal e apresentam atividade inseticida contra uma variedade de lepidópteras (Estruch, J.J. et al., 1996). Essas toxinas são melhor abordadas por Palma et. al. em uma revisão publicada recentemente (Palma, L., Munoz, D., Berry, C., et al., 2014).

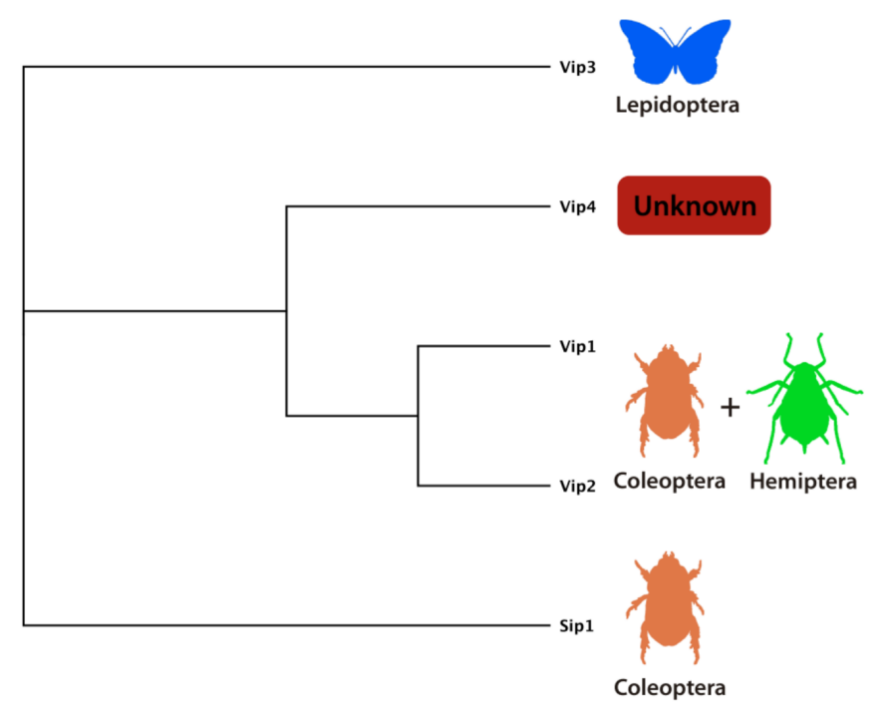

(Palma, L., Munoz, D., Berry, C., et al., 2014)

Figura 6: Ordens de insetos acometidas pelas toxinas Vip e Sip de Bt. 
Algumas toxinas que pertencem ao grupo de 3D-Cry (Cry1I, Cry16A e Cry17A) também foram descritas como proteínas de secreção e não possuem peptídeo sinal. Cry16A e Cry17A são toxinas de Clostridium bifermentans (Barloy, F. et al., 1996; Barloy, F., Lecadet, M.M. \& Delecluse, A., 1998), enquanto Cry1I é uma toxina de Bt (Espinasse, S. et al., 2003; Ruiz de Escudero, I. et al., 2006). A secreção dessas três toxinas pode ser devida à um sistema alternativo de secreção, algo já abordado para outras bactérias patogênicas gram positivas (Pallen, M.J., 2002).

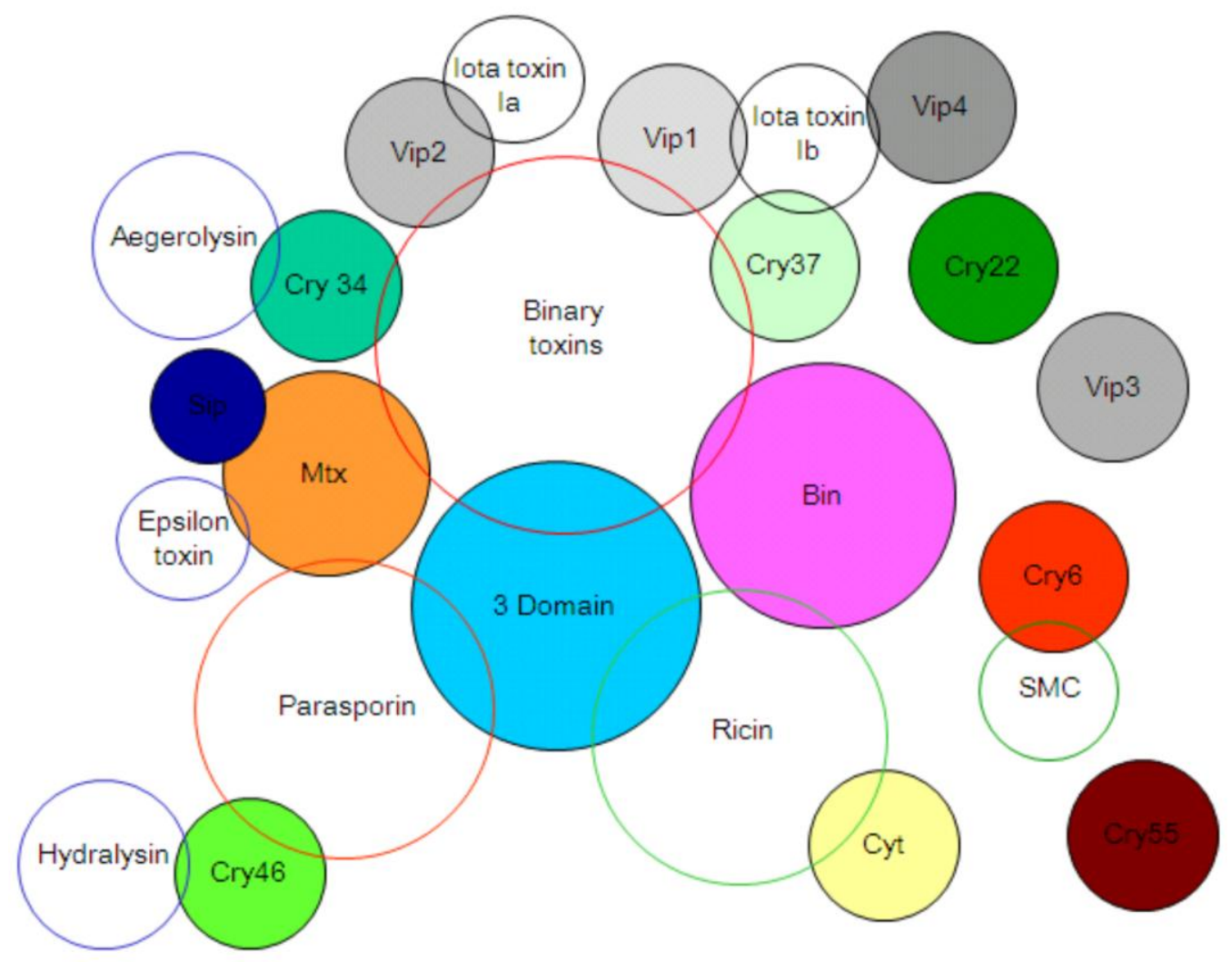

(Krishnan, V., 2013)

Figura 7: Diagrama de Venn retratando a homologia de toxinas Bt aos domínios conservados de famílias proteicas encontradas em diversos organismos. 


\section{$\underline{\text { Outras Toxinas }}$}

Fora as toxinas já mencionadas, o B. thuringiensis produz outros fatores de virulência não específicos, mas importantes, que podem contribuir para sua patogenicidade. São eles: $\boldsymbol{\alpha}$-exotoxina (Krieg, A., 1971; Mohd-Salleh, M.B., Beegle, C.C. \& Lewis, L.C., 1980), $\beta$-exotoxinas (ou thuringiensina, um análogo de adenina) (Carlberg, G., Tikkanen, L. \& Abdel-Hameed, A.H., 1995; Levinson, B.L. et al., 1990; Perani, M., Bishop, A.H. \& Vaid, A., 1998), enterotoxinas (Gaviria Rivera, A.M., Granum, P.E. \& Priest, F.G., 2000; Ngamwongsatit, P. et al., 2008; Swiecicka, I., Van der Auwera, G.A. \& Mahillon, J., 2006), proteases (Agasthya, A.S. et al., 2013; Brar, S.K. et al., 2009), inibidor A (InhA) (Dalhammar, G. \& Steiner, H., 1984; Fedhila, S., Nel, P. \& Lereclus, D., 2002; Lovgren, A. et al., 1990), quitinases (Chigaleichik, A.G., 1976; Gomaa, E.Z., 2012; Ni, H. et al., 2015; Tang, Y. et al., 2012), fosfolipases (Henner, D.J. et al., 1988; Lechner, M. et al., 1989), hemolisinas (Budarina, Z.I. et al., 1994; Honda, T. et al., 1991; Pendleton, I.R., Bernheimer, A.W. \& Grushoff, P., 1973), bacteriocinas (Barboza-Corona, J.E. et al., 2009) e antibióticos, incluindo a Zwittermicina A (ZmA) (Silo-Suh, L.A. et al., 1998; Stabb, E.V., Jacobson, L.M. \& Handelsman, J., 1994). A maioria dos genes de fatores de virulência são controlados pelo regulador de fosfolipase $\mathrm{C}(\mathrm{PlcR})$, um ativador transcricional que acredita-se ativar pelo menos 45 genes (Agaisse, H. et al., 1999; Gohar, M. et al., 2008; Lereclus, D. et al., 2000). A regulação por PlcR é vital para a patogenicidade de $\mathrm{Bt}$ e B. cereus, uma vez que a interrupção do gene PclR reduz acentuadamente ou anula a mortalidade de alvos infectados por esses patógenos (Salamitou, S. et al., 2000). 


\section{2. $\delta$-endotoxinas e a família Cry1A}

$\mathrm{O}$ Bt produz um ou mais tipos de $\delta$-endotoxinas em suas inclusões cristalinas concomitantemente com a esporulação. Proteínas cristais (Cry) ou citolíticas (Cyt), sozinhas ou em suas combinações, constituem as $\delta$-endotoxinas(Jisha, V.N., Smitha, R.B. \& Benjamin, S., 2013). Por definição, proteínas Cry são inclusões cristalinas parasporais produzidas por Bt que exibem toxicidade experimentalmente verificável a um organismo alvo, ou que apresentem similaridade significativa de sequência à uma toxina Cry já descrita. De maneira similar, as proteínas Cyt são inclusões parasporais que exibem ação hemolítica (citolítica) ou que apresentem similaridade óbvia de sequência à uma toxina Cyt já existente. Essas toxinas são altamente específicas a insetos mas inócuas a humanos, vertebrados e plantas, e são completamente biodegradáveis (Bravo, A., Gill, S.S. \& Soberon, M., 2007).
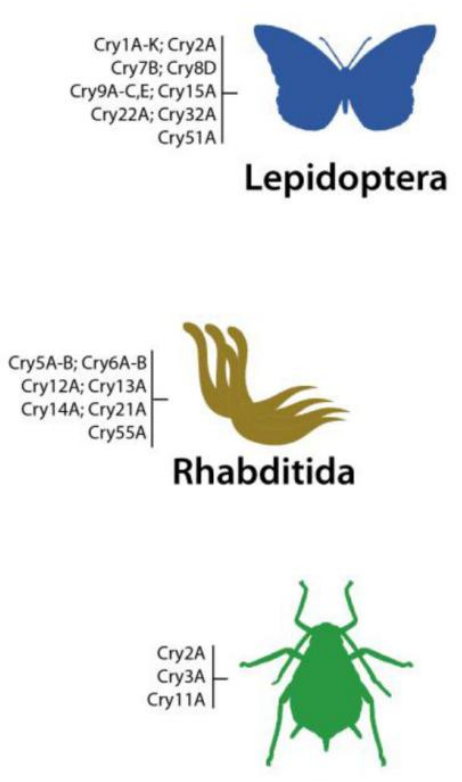

Hemiptera

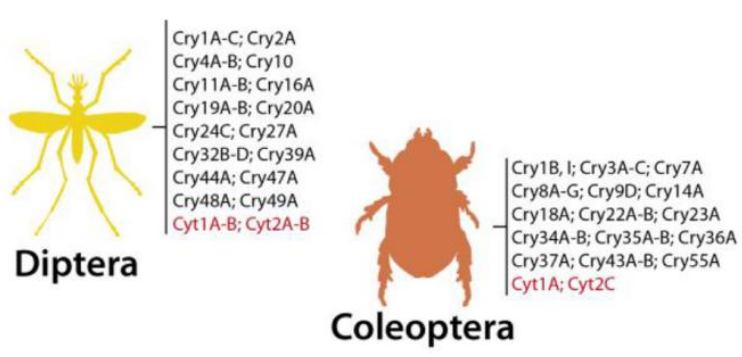

S-Endotoxins

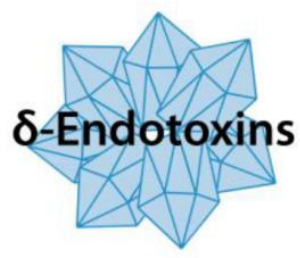

Human-cancer

cells
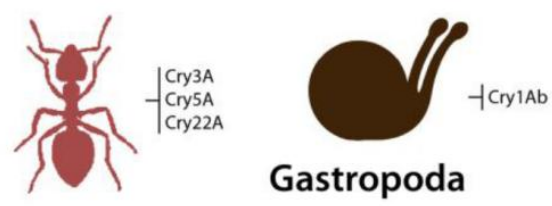

Gastropoda

Hymenoptera

(Palma, L., Munoz, D., Berry, C., et al., 2014)

Figura 8: Hospedeiros suscetíveis às $\delta$-endotoxinas Cry e Cyt (van Frankenhuyzen, K., 2009, 2013). Cry1A-C (separado por hífen) indica um grupo de Cry1A, Cry1B e Cry1C. Cry 1B, C (separado por vírgula), indicam diferentes toxinas Cry1B e Cry1I. Ponto e vírgula separam grupos ou toxinas individuais. Toxinas Cyt estão representadas em vermelho. 
Até o momento, o Comitê para Nomenclatura de Toxinas Bt classificou 73 tipos diferentes de proteínas Cry (Cry1 a Cry73), com toxinas individuais apresentando toxicidade documentada contra Lepidópteras (borboletas e mariposas), Coleópteras (besouros e gorgulhos), Dípteras (mosquitos e moscas), Himenópteras (formigas, abelhas e vespas), Hemípteras (cigarras e afídeos), Nematódeas (Rhabditida), algumas lesmas (Ben-Dov, E., 2014; Bravo, A. \& Soberón, M., 2008; Chougule, N.P. \& Bonning, B.C., 2012; de Maagd, R.A. et al., 2003; Hofte, H. \& Whiteley, H.R., 1989; Schnepf, E. et al., 1998; van Frankenhuyzen, K., 2009, 2013; Wang, A. et al., 2013) e/ou células humanas cancerígenas de várias origens (Ohba, M., Mizuki, E. \& Uemori, A., 2009)(Figura 8). Mais que isso, foi mostrado que larvas de Chlosyne lacinia (Lepidóptera) alimentadas em dieta contendo doses subletais ou baixas concentrações de Cry1 Ac são capazes de captar e transferir essa toxina para os ovos, causando efeitos adversos na primeira geração de prole (Paula, D.P. et al., 2014).

Embora sejam conhecidos 73 grupos de toxinas Cry, as toxinas do grupo Cry1A são as mais estudadas quanto às interações com a membrana e as etapas do mecanismo de ação. Os modelos publicados até o presente momento que se propõem a explicar o modo de ação das $\delta$-endotoxinas Cry baseiam-se na ligação específica e de alta afinidade, da toxina ativada na forma monomérica, à membrana apical do epitélio intestinal (BBMV - "brush border membrane vesicles") dos insetos-alvo (Pigott, C.R. \& Ellar, D.J., 2007; Van Rie, J. et al., 1990). Esta etapa de reconhecimento e ligação à membrana é considerada primordial para a especificidade de uma determinada cepa ou toxina e seu espectro de espécies-alvo. A subclasse Cry1 representa um grupo de proteínas que abrangem 120-140 kDa, em sua forma proativa, e são primariamente tóxicas contra larvas de lepidópteros. Uma vez solubilizadas no ambiente alcalino intestinal, as protoxinas são ativadas por clivagens proteolíticas e processadas em uma toxina de aproximadamente $65 \mathrm{kDa}$.

\subsubsection{Estrutura}

Fora as já mencionadas estruturas cristalográficas que estão depositadas no PDB (Berman, H.M., Westbrook, J., et al., 2000), existem mais dez estruturas únicas de $\delta$ endotoxinas que foram resolvidas por cristalografia de raios-X. Todas são pertencentes à família Cry de três domínios (3D-Cry), sendo oito delas constituídas pela forma ativa das toxinas e duas pela forma inativa (protoxina). A Tabela 4 resume nove dessas 
estruturas cristalográficas. As formas ativas de proteína são: Cry1 Aa (Grochulski, P. et al., 1995), Cry1Ac (Derbyshire, D.J. et al., 2013), Cry3Bb (Galitsky, N. et al., 2001), Cry4Ba (Boonserm, P. et al., 2005), Cry4Aa (Boonserm, P. et al., 2006), Cry8Ea (Guo, S. et al., 2009), Cry5B (Hui, F. et al., 2012) e Cry3Aa (Li, J.D., Carroll, J. \& Ellar, D.J., 1991); enquanto a forma inativa é representada pelas protoxinas próCry1Ac (Evdokimov, A.G. et al., 2014) e Cry2Aa (Morse, R.J., Yamamoto, T. \& Stroud, R.M., 2001). É importante salientar que próCry1Ac e Cry2Aa representam dois tipos de protoxinas distintas, cuja diferença é a presença, ou não, de uma extensão C-terminal. Portanto, próCry1Ac trata-se de uma protoxina extensa e Cry2Aa de uma protoxina curta, muito similar às toxinas ativas (Tabela 4). Apesar da diferença na identidade de resíduos de aminoácidos $(<45 \%)$ quando comparamos famílias 3D-Cry de primeira categoria diferentes, i.e. Cry1, Cry2, Cry3, Cry4, Cry8 e Cry5, pode ser percebida uma notável similaridade e conservação de estrutura entre elas. Todas são constituídas por três domínios bem definidos (facilmente distintos) e contíguos (possuem interface de contato entre si).

\begin{tabular}{|c|c|c|c|c|c|c|c|c|}
\hline Toxin & Target Insects & Expressing Strain & Activation & Resolution & PDB ID & Domain I & Domain II & Domain III \\
\hline Cry1Aa & Lepidoptera & Bt kurstaki HD-1 & $\begin{array}{l}\text { Trypsin } \\
65 \mathrm{kDa}\end{array}$ & $2.25 \AA$ & $1 \mathrm{CIY}$ & resi 33-253 & resi 265-461 & $\begin{array}{c}\text { resi } 463-609 \text {, } \\
\text { resi } 254264\end{array}$ \\
\hline CrylAc* & Lepidoptera & Bt kurstaki HD73 & $\begin{array}{l}\text { Trypsin } \\
65 \mathrm{kDa}\end{array}$ & $2.35 \AA$ & $4 \mathrm{ARX}$ & resi 31-263 & resi $255-462$ & resi 463-609 \\
\hline Cry2Aa & $\begin{array}{c}\text { Diptera } \\
\text { Lepidoptera }\end{array}$ & Bt kurstaki HD-1 & $\begin{array}{c}\text { Protoxin } \\
62 \mathrm{kDa}\end{array}$ & $2.2 \AA$ & $1 \mathrm{II} \mathrm{P}$ & resi $1-272$ & resi $273-473$ & resi $474-633$ \\
\hline Cry3Aa & Coleoptera & Bt tenebrionis 1911 & $\begin{array}{l}\text { Papain } \\
67 \mathrm{kDa}\end{array}$ & $2.5 \AA$ & 1DLC & resi $61-290$ & resi $291-500$ & resi $501-644$ \\
\hline Cry3Bb & Coleoptera & E. coli $\mathrm{EG} 7231$ & $67.2 \mathrm{kDa}$ & $2.4 \AA$ & $1 \mathrm{JI} 6$ & resi 64-294 & resi $295-503$ & resi 504-652 \\
\hline Cry4Aa & Diptera & Bt israelensis & $\begin{array}{l}\text { Trypsin } \\
65 \mathrm{kDa}\end{array}$ & $2.8 \AA$ & $2 \mathrm{C} 9 \mathrm{~K}$ & resi $68-321$ & resi $322-524$ & resi 525-679 \\
\hline Cry4Ba & Diptera & Bt israelensis & $\begin{array}{c}\text { Chymotrypsin } \\
68 \mathrm{kDa}\end{array}$ & $1.75 \AA$ & 1W99 & resi $84-282$ & resi $283-466$ & resi $467-641$ \\
\hline Cry8Ea* & Coleoptera & Bt185 & $\begin{array}{c}\text { Chymotrypsin } \\
66.2 \mathrm{kDa}\end{array}$ & $2.2 \AA$ & 3EB7 & resi $64-290$ & resi $291-500$ & resi $501-652$ \\
\hline Cry5B & Nematode & $\begin{array}{c}\text { Bt kurstaki HD-1(Native) } \\
\text { E.coli } \mathrm{M} 15 \text { (Sel-Met) }\end{array}$ & $\begin{array}{c}\text { Elastase } \\
66.14 \mathrm{kDa}\end{array}$ & $2.3 \AA$ & $4 \mathrm{D} 8 \mathrm{M}$ & resi $112-328$ & resi $341-541$ & resi $541-698$ \\
\hline
\end{tabular}

* Three domain regions are estimated according to PDB results.

(Xu, C. et al., 2014)

Tabela 4: Resumo de proteínas 3D-Cry que tiveram suas estruturas cristalográficas resolvidas.

O domínio I (D-I) é um agregado de sete $\alpha$-hélices ( $\alpha 1$ a $\alpha 7$ ) localizado na extremidade N-terminal. Elas possuem cerca de $30 \AA$ e estão organizadas na topologia "up and down", com até seis hélices anfipáticas circundando a $\alpha$-hélice hidrofóbica, $\alpha 5$, situada ao centro do domínio (Figura 9) (Li, J.D., Carroll, J. \& Ellar, D.J., 1991; Pigott, 
C.R. \& Ellar, D.J., 2007). Em algumas toxinas a $\alpha$-hélice 2 pode ser interrompida por um loop e consequentemente dividida em duas subunidades ( $\alpha 2 \mathrm{a}$ e $\alpha 2 \mathrm{~b}$ ).

O domínio II (D-II) é um prisma- $\beta$ composto por três folhas- $\beta$ antiparalelas organizadas em topologia "greek-key" e uma $\alpha$-hélice em C-terminal, contendo duas subunidades ( $\alpha 8 \mathrm{a}$ e $\alpha 8 \mathrm{~b}$ ), adjacente ao fragmento polipeptídico que une o D-II ao D-I. Esse domínio possui um núcleo hidrofóbico e expõe ao solvente quatro loops hidrofílicos com alta variação de sequência entre as 3D-Cry, responsáveis por caracterizá-lo como o domínio de maior divergência (Xu, C. et al., 2014).

Por fim, o domínio III (D-III) tem a conformação de um sanduíche- $\beta$ composto por duas folhas- $\beta$ antiparalelas organizadas em topologia "jelly-roll" (Figura 9). Cada folha- $\beta$ é formada por cinco fitas- $\beta$ e se encontram opostas uma a outra, de maneira que a folha contendo C-terminal está na interface entre os outros dois domínios e a outra está completamente exposta ao solvente. Este é o domínio de maior conservação estrutural entre toxinas 3D-Cry, com as folhas- $\beta$ se sobrepondo em alinhamentos estruturais, e contém três blocos de sequências conservadas (Figura 10). As poucas variações observadas neste domínio estão localizadas principalmente em seus loops conectores (Ibrahim, M.A. et al., 2010; Schnepf, E. et al., 1998; Xu, C. et al., 2014). A interface de contato entre os três domínios está distribuída ao longo do fragmento contendo as fitas $\beta 0$ e $\beta 1$ e a hélice $\alpha 7$ (bloco conservado 2, Figura 10). A estrutura de próCry1 Ac está descrita na legenda da Figura 11.

As toxinas de $\mathrm{Bt}$, compartilham várias características estruturais e funcionais comuns às toxinas formadoras de poro (PFTs). As PFTs podem ser categorizadas em dois tipos: toxinas formadoras de poro alfa $(\alpha-\mathrm{PFT})$, que formam poros transmembrana utilizando $\alpha$-hélices, e toxinas formadoras de poro beta ( $\beta$-PFT), que formam poros utilizando folhas- $\beta$ em uma conformação de barril. Utilizando esse conceito, foi proposto a categorização estrutural das $\delta$-endotoxinas de $\mathrm{Bt}$ em três tipos: 3D-Cry tipo $\alpha$-PFT, Cyt tipo $\beta$-PFT e Aerolisinas tipo $\beta$-PFT (Xu, C. et al., 2014). 


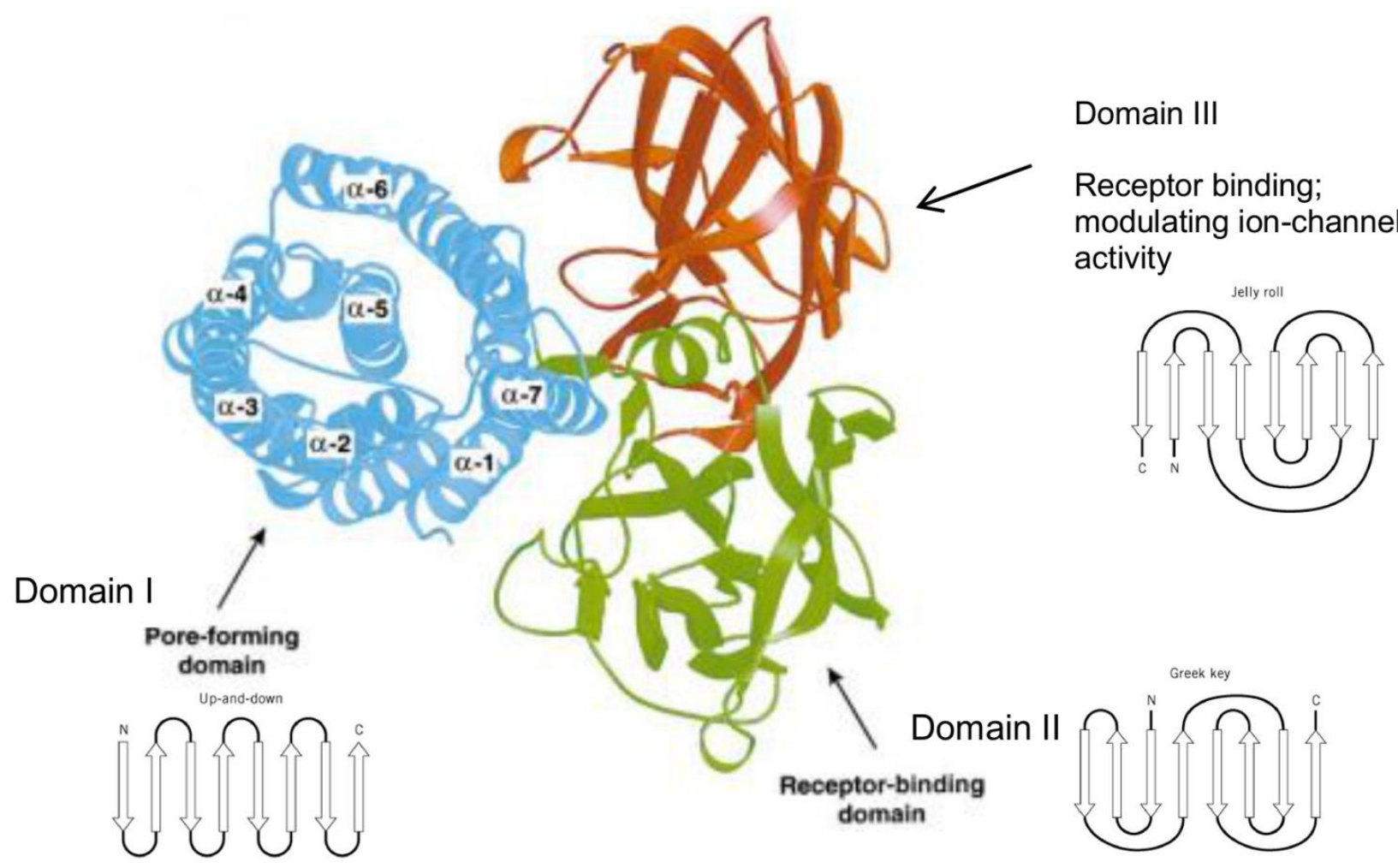

Figura 9: Estrutura tridimensional de uma proteína da família 3D-Cry. O domínio I é um agregado de sete $\alpha$-hélices organizadas na topologia "up and down". O domínio II é um prisma- $\beta$ composto por três folhas- $\beta$ antiparalelas organizadas em topologia "greek-key". O domínio III tem a conformação de um sanduíche- $\beta$ composto por duas folhas- $\beta$ antiparalelas organizadas em topologia "jelly-roll". Um exemplo ilustrativo de cada uma dessas topologias é mostrado ao lado de cada domínio.

O D-I da família 3D-Cry apresenta significativa similaridade estrutural com o domínio formador-de-poro da $\alpha$-PFT colicina A. Por este motivo, D-I é considerado determinante no processo de penetração da membrana e formação de poro (Grochulski, P. et al., 1995). O D-II, baseado nas variações de sequência, comprimento e estrutura de seus loops, é tido como o principal atuante no reconhecimento de receptores celulares do inseto-alvo, e, portanto, determinante na especificidade das toxinas 3D-Cry (Hofte, H. \& Whiteley, H.R., 1989; Ibrahim, M.A. et al., 2010). Já o D-III possui estrutura semelhante aos domínios de ligação a carboidratos de outras proteínas, com os sítios de ligação a carboidratos localizados em duas fendas situadas no centro de cada folha- $\beta$ (de Maagd, R.A. et al., 2003). Cry1Ac se diferencia das demais toxinas da família Cry1A por possuir um sítio de ligação a N-acetilgalactosamina (Gal-NAc) em D-III, o que tem implicações no modo de ação dessa toxina (Derbyshire, D.J., Ellar, D.J. \& Li, J., 2001). Por esses motivos, acredita-se que D-III tenha função relacionada com 0 
reconhecimento de receptores e inserção da toxina na membrana (de Maagd, R.A., Bravo, A. \& Crickmore, N., 2001).

O alinhamento de sequências das proteínas 3D-Cry revelou a presença de cinco blocos conservados distribuídos ao longo da cadeia peptídica de toxinas na forma ativa (Figura 10). Nem todas as toxinas possuem os cinco blocos, mas uma vez presentes, é possível observar uma alta similaridade ou identidade de resíduos de aminoácidos. Estes blocos estão localizados nas regiões que conectam um domínio ao outro e na interface de contato entre eles, bem como na $\alpha$-hélice 5, que é o cerne hidrofóbico do D-I. Logo, acredita-se que estes blocos são responsáveis pela manutenção da estrutura globular das toxinas (Hofte, H. \& Whiteley, H.R., 1989; Schnepf, E. et al., 1998).

Recentemente, um trabalho muito interessante utilizou-se do fato de as $\delta$ endotoxinas de $\mathrm{Bt}$ formarem naturalmente cristais in vivo e resolveram (novamente) a estrutura da toxina Cry3 Aa injetando bactérias vivas em um laser de raios-X gerado por elétrons livres (XFEL) (Sawaya, M.R. et al., 2014). O resultado foi uma estrutura cristalográfica com resolução de 2,9 Å de um cristal proteico assim como ele existe em células vivas. O trabalho concluiu que estudos autênticos de difração in vivo podem gerar informações estruturais de nível atômico (Sawaya, M.R. et al., 2014).

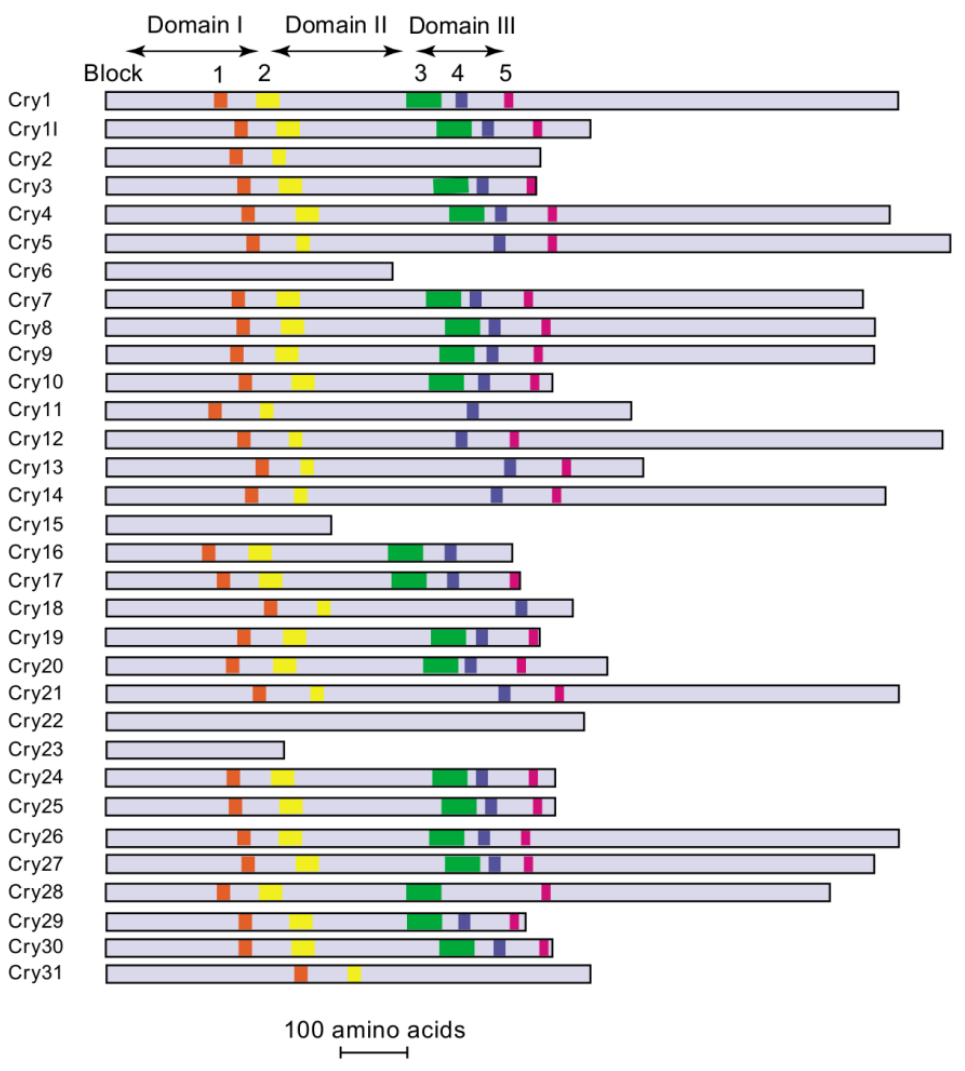

Figura 10: Tamanho relativo de protoxinas Cry e a posição dos cinco blocos conservados. Blocos conservados estão coloridos da seguinte maneira: 1, laranja; 2, amarelo; 3, verde; 4, azul; e 5, roxo. (de Maagd, R.A., Bravo, A. \& Crickmore, N., 2001) 


\subsubsection{Protoxinas e Cristalização}

É interessante notar que a maioria das toxinas inseticidas discutidas aqui estão localizadas dentro de corpos de inclusão cristalinos. Sugere-se que isso seja necessário para o empacotamento de altas concentrações de toxinas de uma forma que estas consigam sobreviver no ambiente por um tempo viável após a esporulação. O tamanho e insolubilidade da inclusão cristalina em $\mathrm{pH}$ neutro previne que as toxinas sejam lixiviadas para o solo, por exemplo (de Maagd, R.A. et al., 2003). Até o momento, a única região implicada na cristalização é a extensão C-terminal presente em algumas protoxinas da família 3D-Cry (Figura 11). Essas regiões podem chegar a ter mais resíduos de aminoácidos que a própria toxina e a expressão de toxinas contendo o Cterminal truncado (interrompido) não forma inclusões cristalinas (Park, H.W., Bideshi, D.K. \& Federici, B.A., 2000). Comparado aos outros três domínios, a extensão Cterminal é a mais conservada nas protoxinas, o que sugere uma função crucial ou uma aquisição evolucionária mais recente.

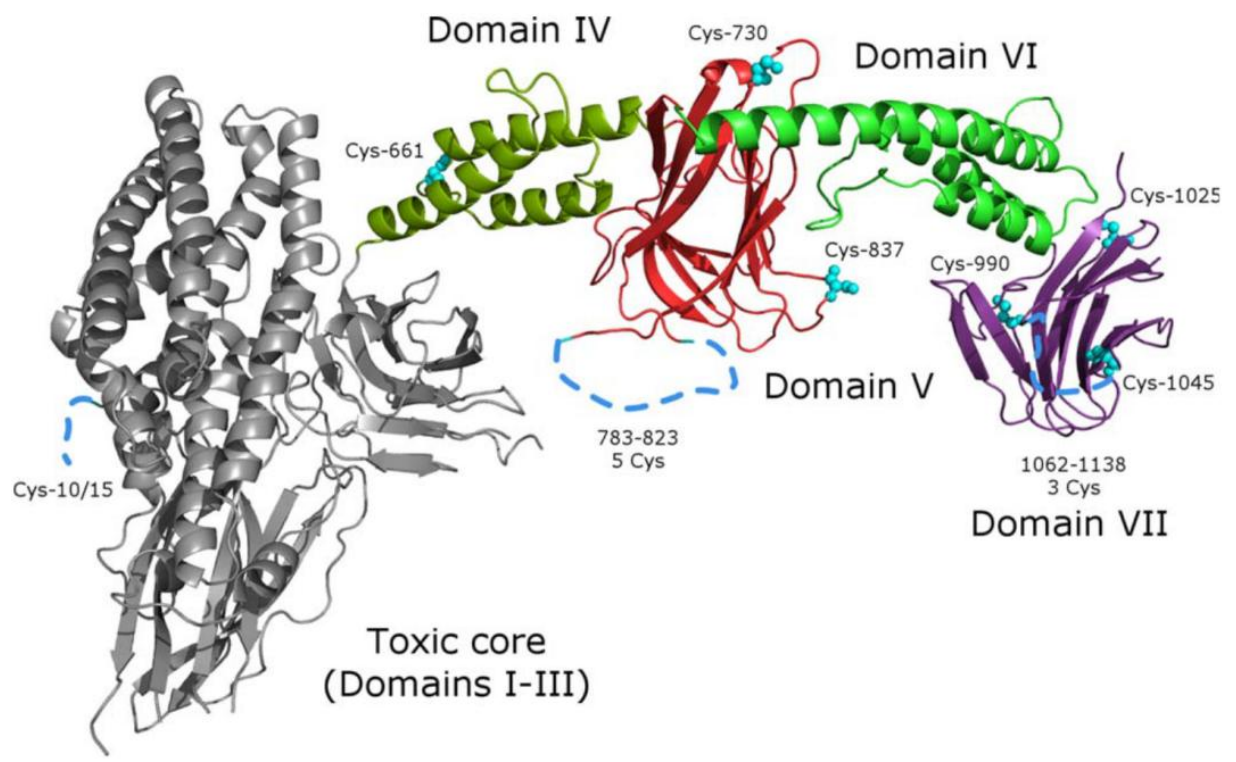

(Evdokimov, A.G. et al., 2014)

Figura 11: Estrutura cristalográfica da protoxina de Cry1Ac (PDB ID 4W8J). A toxina (à esquerda, em cinza) já está corretamente enovelada em três domínios enquanto a extensão C-terminal (à direita, em cores) está organizada em quatro domínios. Domínio IV e VI são formadas por $\alpha$-hélices, enquanto domínios V e VII estão na topologia de barril- $\beta$. O dímero de protoxinas visto no empacotamento do cristal mostra que a toxina de um monômero está protegida "sob abrigo" da extensão C-terminal do outro monômero. Embora a próCry1 Ac usada nesse estudo tenha tido 14 de suas 16 cisteínas removidas para facilitar os experimentos, as localizações naturais destas indicam ligações cruzadas de ligações dissulfeto que estabilizam os cristais naturais. 
Alguns genes cry (cry10Aa, cry39Aa e cry40Aa) não codificam a extensão Cterminal diretamente mas, ao invés, possuem uma segunda sequência de leitura aberta (ORF), cerca de 100 pb à jusante, que codifica um homólogo da extensão C-terminal. Embora a região separando as duas ORFs não apresente homologia à transposons e sequências de inserção, é possível que genes cry individuais estejam adquirindo a extensão por meio de recombinação ou transposição. Apesar de as evidências apontarem para a importância da extensão C-terminal no processo de cristalização, há toxinas, e.g., Cry11A e Cry3A, que não possuem essa região mas são claramente capazes de cristalizar in vivo (de Maagd, R.A. et al., 2003). É sugerido que a cristalização dessas toxinas requeiram a colaboração de pelo menos uma de duas proteínas auxiliares, P19 e P20 (Agaisse, H. \& Lereclus, D., 1995; Berry, C. et al., 2002; Ibrahim, M.A. et al., 2010; Shao, Z., Liu, Z. \& Yu, Z., 2001; Xu, Y. et al., 2001). Em Bt, a proteína Cry1Ac é substancialmente degradada no processo de expressão, principalmente durante sua síntese antes da cristalização (Shao, Z., Liu, Z. \& Yu, Z., 2001). Nesse caso, a introdução de P20 melhorou significativamente a expressão de Cry1Ac e postula-se que isso é devido à proteção do peptídeo nascente (Shao, Z., Liu, Z. \& Yu, Z., 2001). O gene p20 foi detectado em várias cepas de $\mathrm{Bt}$, sugerindo que P20 pode ser um fator bastante difundido influenciando a cristalização de toxinas Cry (Deng, C. et al., 2014)

Já as famílias de toxinas Cry2A e Cry19A são notáveis por necessitar da expressão de um segundo gene para a formação de inclusões cristalinas (BarbozaCorona, J.E. et al., 2012; Ge, B. et al., 1998). As toxinas da família Cry2A são expressas como o terceiro gene de um operon de três genes e o produto de $29 \mathrm{kDa}$ do segundo gene (Orf2) é necessário para a formação dos cristais de Cry2A (Ge, B. et al., 1998; Staples, N., Ellar, D. \& Crickmore, N., 2001). O fator de cristalização Orf2 é uma proteína constituída, em grande parte, por 11 repetições em tandem de 15 ou 16 resíduos de aminoácidos e pode ser co-precipitada com Cry2A. A presença de resíduos ácidos nessas repetições proporciona um paralelo interessante com relatos de que alguns cristais contém DNA em sua constituição e de que estes participariam na formação de cristais (Clairmont, F.R. et al., 1998). Uma análise das sequências codantes (CDS) de várias protoxinas de Bt revelaram a presença de repetições em tandem similares às de Orf2, localizadas em C-terminal das toxinas ativas (Figura 12). No entanto, as repetições codificadas nessas toxinas são ricas em resíduos de glutamina (Q) e asparagina (N), e a função destes resíduos ainda não está clara (de Maagd, R.A. et al., 
2003). A extensão C-terminal é claramente importante para a cristalização de algumas proteínas mas aparenta ser redundante em outras. Uma investigação pertinente seria fusionar a extensão C-terminal à proteínas de interesse, utilizando-a como uma ferramenta para auxiliar na obtenção de cristais proteicos, para posterior difração usando cristalografia de raios-X. Recentemente foi publicada a primeira estrutura cristalográfica de uma protoxina de Bt contendo a extensão C-terminal (Evdokimov, A.G. et al., 2014), mas ainda há muito a ser compreendido sobre sua organização estrutural e suas interações in-vivo.

Fora as inclusões cristalinas, toxinas da família Cry1Ac também foram presenciadas dentro das camadas de proteção do esporo de $\mathrm{Bt}$, onde podem afetar sua capacidade de germinação (Du, C. \& Nickerson, K.W., 1996). Acredita-se que essa interação seja mediada por ligações dissulfeto entre a extensão C-terminal e o invólucro do esporo, ambos ricos em cisteínas (Du, C. \& Nickerson, K.W., 1996). Isso e a observação de que a extensão C-terminal apresenta similaridade de sequência com a proteína de invólucro esporal, CotA, de B. subtilis, sugerem que ao menos essa região da toxina possa ter evoluído de uma proteína esporal (de Maagd, R.A. et al., 2003).

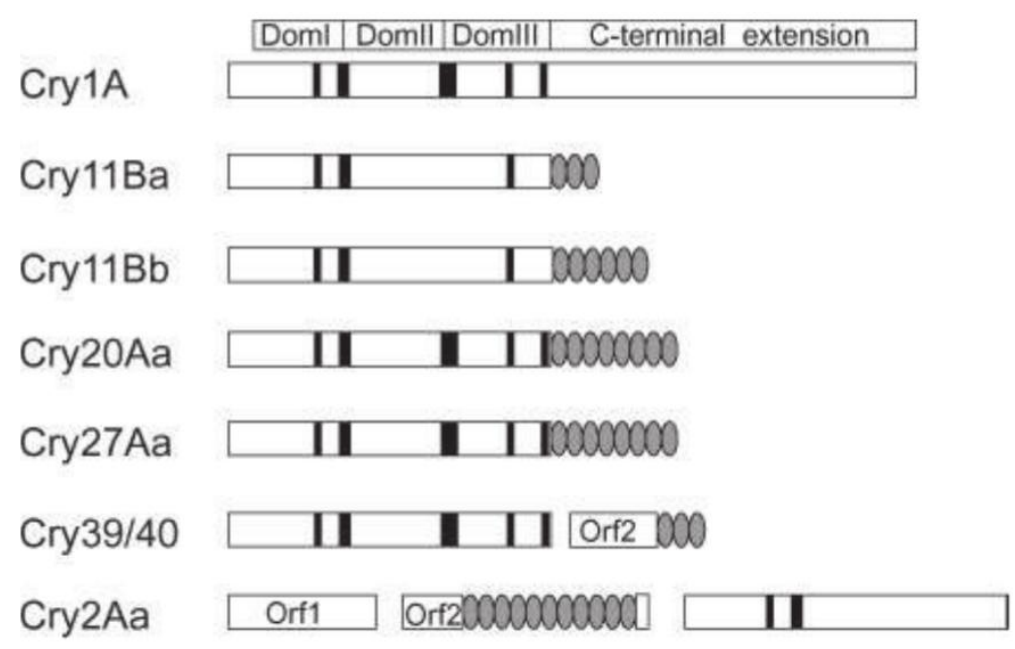

(de Maagd, R.A. et al., 2003)

Figura 12: Diagrama representando a repetição de sequências $C$-terminais em algumas toxinas entomocidas. As caixas brancas representam a região proteica das toxinas; as caixas pretas internas representam blocos conservados (Schnepf, E. et al., 1998); e cada ovo cinza representa uma única repetição de sequência. 


\subsubsection{Mecanismo de Ação}

As proteínas da família 3D-Cry são sintetizadas como toxinas inativas e, portanto, denominadas de protoxinas. As protoxinas são expressas durante a esporulação da bactéria e formam grandes inclusões cristalinas que contêm uma ou mais proteínas de ação inseticida (toxinas Cry e Cyt), também chamadas de $\delta$-endotoxinas (Figura 1)(Hofte, H. \& Whiteley, H.R., 1989; Schnepf, E. et al., 1998). Essas inclusões permitem o empacotamento de altas concentrações de protoxinas e as protegem de ambientes hostis por um tempo considerável após a esporulação. Isso proporciona meios para que as protoxinas sejam corretamente ativadas e as toxinas ativas cheguem ao seus alvos. Existem dois modelos que descrevem o mecanismo citotóxico das proteínas 3D-Cry e embora eles compartilhem as mesmas etapas iniciais, eles apontam diferentes causas para a morte celular:a indução de apoptose (morte celular programada) e a formação de poros por oligômeros proteicos (que geram um desequilíbrio iônico e osmótico).

Nas etapas comuns aos dois mecanismos, primeiramente as inclusões cristalinas são solubilizadas no intestino do inseto e as protoxinas vão sendo liberadas no lúmen. As protoxinas, por sua vez, são alvo de enzimas no intestino e têm suas extremidades Ne C-terminal clivadas (Figura 13). O resultado dessa ação enzimática é uma toxina ativa, contendo os três domínios característicos da família 3D-Cry, e capaz de reconhecer receptores específicos na membrana de células intestinais. Sugere-se que os domínios II e III sejam responsáveis pela ligação da toxina ao receptor tipo-caderina, considerado o receptor primário. A ligação ao receptor caderina induz mudanças conformacionais na toxina que permitem, ainda, a clivagem N-terminal da hélice $\alpha 1$ no D-I. Não sabe-se ao certo qual a enzima responsável por essa clivagem, mas o sítio de clivagem entre F50 e V51, nas toxinas da família Cry1A, sugere tratar-se de uma enzima tipo-quimotripsina presente na membrana intestinal do inseto (Gomez, I. et al., 2002). De qualquer forma, esse acontecimento é responsável pela perda de afinidade da toxina à caderina e consequente dissociação entre ambas (Bravo, A. et al., 2004; Pacheco, S. et al., 2009; Sangadala, S. et al., 1994; Vadlamudi, R.K., Ji, T.H. \& Bulla, L.A., Jr., 1993). 


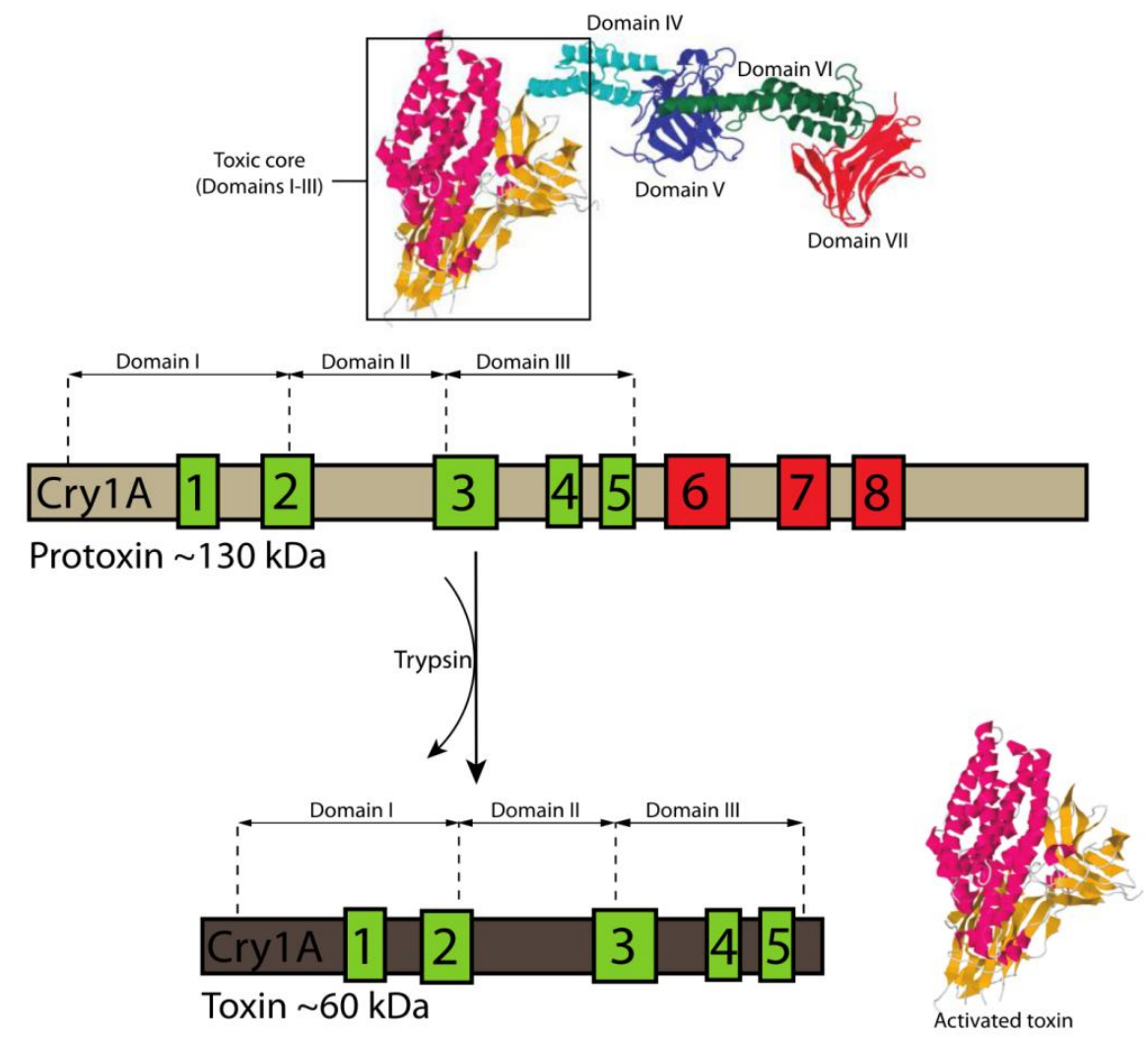

(Palma, L., Munoz, D., Berry, C., et al., 2014)

Figura 13: Ativação da protoxina em uma proteína ativa. Destacado em verde estão os cinco blocos conservados distribuídos entre os três domínios. Em vermelho estão as três regiões conservadas da extensão C-terminal.

Cada etapa do mecanismo pode modular a atividade contra um inseto particular e, portanto, a especificidade geral de uma toxina. A solubilização das protoxinas extensas (que contêm a extensão C-terminal) depende do $\mathrm{pH}$ intestinal altamente alcalino de Lepidópteras e Dípteras (de Maagd, R.A., Bravo, A. \& Crickmore, N., 2001). Algumas das toxinas com potencial atividade contra Coleópteras só são tóxicas após solubilização in vitro, possivelmente porque a protoxina é insolúvel no $\mathrm{pH}$ intestinal levemente ácido dessa ordem de insetos (Bradley, D. et al., 1995). É interessante notar que a maioria das toxinas com atividade contra Lepidópteras (Cry1, Cry2 e Cry9) possuem arginina como o aminoácido básico predominante, em detrimento à lisina (exceto, curiosamente, Cry1I). Essa tendência não é vista em Coleópteras, o que sugere que o alto $\mathrm{pK}_{\mathrm{a}}$ da arginina pode ser necessário para a manutenção da carga positiva no elevado pH intestinal de Lepidópteras (de Maagd, R.A., Bravo, A. \& Crickmore, N., 2001; Grochulski, P. et al., 1995). 
Diferenças na atividade proteolítica do intestino entre diferentes insetos-alvo também pode conduzir para diferenças de especificidade (Bradley, D. et al., 1995; Haider, M.Z., Knowles, B.H. \& Ellar, D.J., 1986). Por exemplo, as principais proteases digestivas de Lepidópteras e Dípteras são serino-protesases, enquanto as de Coleópteras são principalmente cisteíno-proteases e aspartato-proteases (Terra, W.R. \& Ferreira, C., 1994). A ativação da toxina é um processo complexo; além da proteólise da protoxina em $\mathrm{N}$ - e C-terminal, foi relatado o processamento intramolecular dos domínios I e II de algumas toxinas (Carroll, J. et al., 1997; Lightwood, D.J., Ellar, D.J. \& Jarrett, P., 2000; Miranda, R., Zamudio, F.Z. \& Bravo, A., 2001). Mais ainda, a clivagem da hélice $\alpha 1$ no domínio I foi correlacionado com ativação da toxina para formação de oligômeros e inserção na membrana (Gomez, I. et al., 2002). Por outro lado, a falta de uma protease importante pode resultar em resistência do inseto (Oppert, B. et al., 1997), bem como a degradação rápida demais de algumas toxinas Cry no intestino de larvas em estágio avançado (Keller, M. et al., 1996).

A segunda parte do mecanismo citotóxico é onde o modelo de "formação de poro" e o modelo de "transdução de sinal" divergem. A Figura 14 ilustra a divisão da rota percorrida por ambos os modelos após a ligação ao receptor primário do tipo caderina (passo 3). O primeiro mostra que a remoção da $\alpha$-hélice causa uma redução na afinidade da toxina à caderina, permitindo que esta se desassocie e forme um tetrâmero "pré-poro" (passo 4). O tetrâmero, por sua vez, ganha afinidade a um receptor secundário, a aminopeptidase, que permite a inserção da estrutura pré-poro na membrana (passo 5) (Pacheco, S. et al., 2009). A inserção do tetrâmero forma um poro seletivo à íons positivos responsável por um desequilíbrio iônico que resulta no rompimento osmótico da membrana (passo 6).

De acordo com o modelo de transdução de sinal, a citotoxicidade das toxinas Cry é inteiramente mediada por meio de uma ligação específica ao receptor primário do tipo caderina. A ligação é responsável por transduzir uma mensagem secundária mediada por proteína $\mathrm{G}$ e dependente de $\mathrm{Mg}^{2+}$, que induz a produção de AMP cíclico pela proteína adenil ciclase (AC) e ativa proteína quinase A (PKA), desencadeado a morte da célula por necrose. Os autores responsáveis por esse modelo vão mais adiante e afirmam que "o complexo oligomérico incorporado à membrana não forma poros líticos e não apresenta qualquer efeito tóxico à célula." (Zhang, X. et al., 2005). 


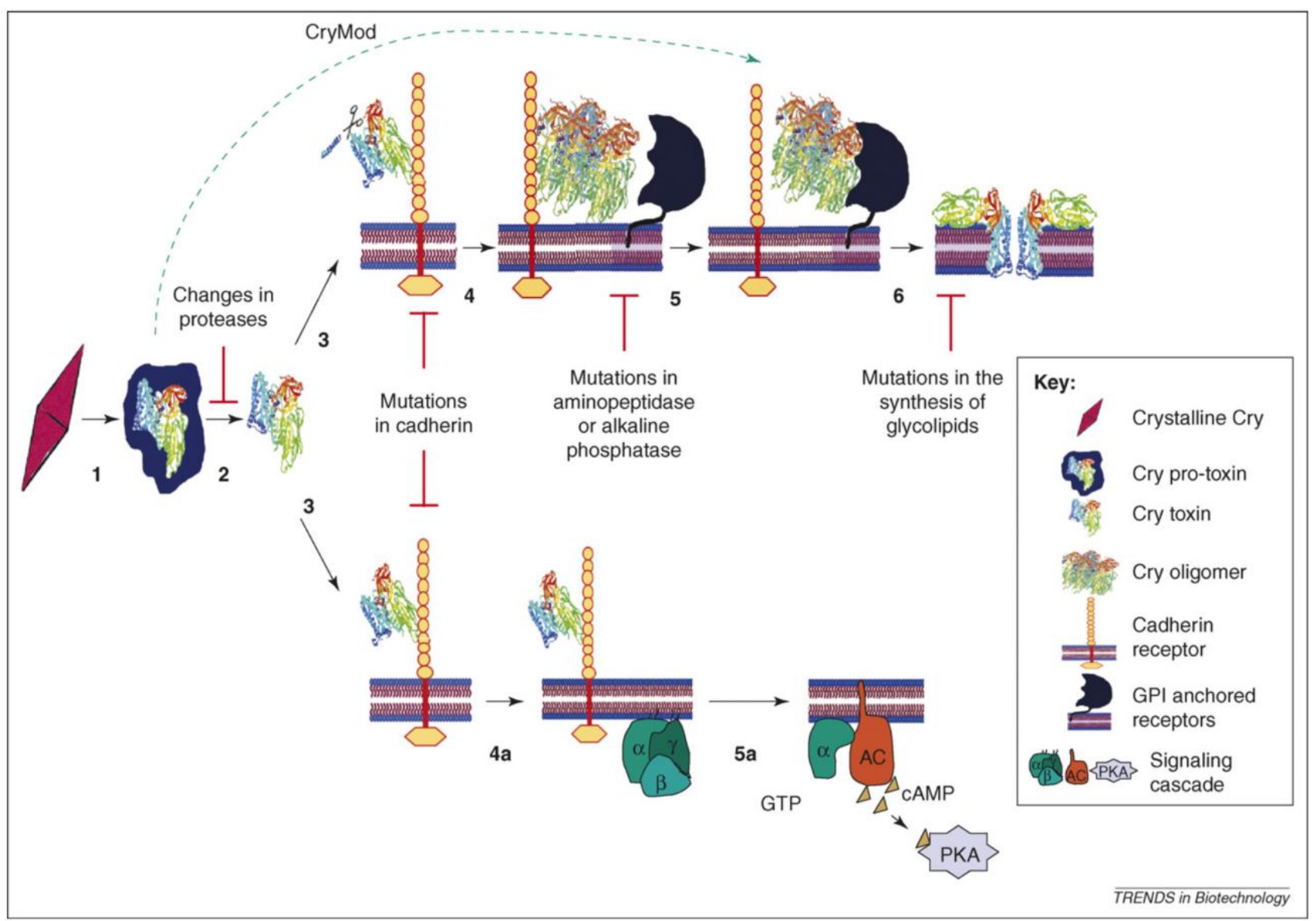

(Bravo, A. \& Soberón, M., 2008)

Figura 14: Os dois modelos citotóxicos das toxinas 3D-Cry. A parte superior ilustra o modelo de formação de poro e a parte inferior, o modelo de transdução de sinal.

\subsubsection{Receptores}

Estudos posteriores comprovaram a participação de diferentes classes de proteínas de membrana com uma participação efetiva no mecanismo de ação. Atualmente, são conhecidos como receptores funcionais ou ligantes das toxinas 3D-Cry as proteínas pertencentes às famílias das caderinas (CAD), aminopeptidases N (APN), fosfatases alcalinas (ALP) (Zúñiga-Navarrete, F. et al., 2013), um glicoconjugado de $270 \mathrm{kDa}$ (BTR-270) e uma proteína de $252 \mathrm{kDa}$ (P252), metaloproteases (ADAM), $\alpha$ glicosidases (Zhang, Q. et al., 2013), $\alpha$-amilases (Fernandez-Luna, M.T. et al., 2010), simportador de sódio (Contreras, E. et al., 2013) e o cassete transportador de ligação ao ATP, C2 (Tanaka, S. et al., 2013). Além disso, glicolipídeos também estão associados à ligação com toxinas Cry em Nematódea (Pigott e Ellar 2007). 
As aminopeptidades N (APNs) são metaloproteases dependentes de zinco que clivam as extremidades $\mathrm{N}$-terminais de cadeias polipeptídicas e tem uma participação primordial na digestão dos insetos (Terra, W.R. \& Ferreira, C., 1994). A partir de 1994, APNs conectadas à membrana apical por âncoras do tipo glicofosfatidilinositol (GPI) passaram a ser identificadas como receptores para as toxinas Cry (Luo, K. et al., 1997; Valaitis, A.P. et al., 1995). Estas proteínas estão distribuídas em cinco classes e compartilham $61 \%$ de identidade na sequência de aminoácidos dentro de uma mesma classe, e 26-38\% de identidade entre classes distintas (Herrero, S. et al., 2005).

Estas aminopeptidades $\mathrm{N}$ possuem sítios de $\mathrm{N}$ e O-glicosilações que são importantes para a interação com as toxinas. Os sítios de O-glicosilações podem variar de seis em B. mori, dez em M. sexta e 39 em H. armigera (Pigott, C.R. \& Ellar, D.J., 2007). As N-glicosilações da APN1 de M. sexta foram mapeadas por meio de espectrometria de massa, revelando cadeias incomuns para glicoproteínas de insetos (Stephens, E. et al., 2004)

A aminopeptidase $\mathrm{N}$ de $M$. sexta $(120 \mathrm{kDa}$ APN) foi a primeira identificada como receptor para as três toxinas Cry1A e, até o presente momento, é a mais estudada (Lucena, W.A., 2012). Este receptor liga-se às toxinas por dois sítios distintos de ligação. O primeiro é compartilhado pelas três toxinas, enquanto que o segundo é exclusivo para a Cry1 Ac (Knight, P.J., Crickmore, N. \& Ellar, D.J., 1994). Além disso, a ligação à Cry1 Ac é inibida pela presença de GalNAc.

Fosfatases são hidrolases responsáveis pela remoção inespecífica do grupamento fosfato (desfosforilação) em diferentes moléculas. As fosfatases alcalinas (ALP) são ativas em $\mathrm{pH}$ básico e nos insetos, encontram-se mais frequentemente fixadas às membranas apicais das microvilosidades intestinais, podendo eventualmente serem encontradas em membranas basolaterais ou mesmo em solução (Lucena, W.A., 2012). A fosfatase alcalina melhor estudada em insetos foi isolada de B. mori e possui, assim como as aminopeptidases $\mathrm{N}$, uma âncora do tipo GPI, um sítio de ligação ao zinco e Nglicosilações (Terra, W.R. \& Ferreira, C., 1994).

Embora menos estudadas que as CADs e APNs, as ALPs já foram descritas como receptores ou ligantes para as toxinas 3D-Cry em $M$. sexta, $H$. virescens, $A$. aegypti, Anopheles gambiae, Anthonomus grandis e em T. molitor. As ALPs de $H$. virescens $(68 \mathrm{kDa})$ e de $M$. sexta $(65 \mathrm{kDa})$, ambas com âncoras do tipo GPI, foram 
validadas como receptores para a Cry1Ac e esta ligação foi relacionada à presença de N-oligossacarídeos com grupamentos Gal-NAc associados (Jurat-Fuentes, J.L. et al., 2004; McNall, R.J. \& Adang, M.J., 2003).

Os glicolipídeos têm sido identificados como receptores para as toxinas 3DCry entre os Nematódea, especificamente em trabalhos com linhagens de Caenorhabditis elegans resistentes às Cry5Ba (Griffitts, J.S. et al., 2005; Marroquin, L.D. et al., 2000). Mutações nos genes de uma glicosiltransferase foram associadas aos fenótipos de resistência e a sua contribuição na internalização das toxinas foi demonstrada por meio de ensaios de fluorescência com Cry5Ba marcada (Griffitts, J.S. et al., 2003; Kawar, Z.S., Van Die, I. \& Cummings, R.D., 2002). BTR-270 é um glicoconjugado que foi isolado de $L$. díspar e apresentou uma afinidade de ligação para as Cry1Aa, Cry1 Ab e Cry1Ac de 49 nM, 17 nM e 390 nM, respectivamente, e não se liga à Cry3Aa (Valaitis, A.P. et al., 2001).

Em B. mori, uma proteína de $252 \mathrm{kDa}$ (P252) forma oligômeros de $985 \mathrm{kDa}$ e tem afinidade de ligação de 28,9, 178,5 e 20,0 nM para as Cry1Aa, Cry1Ab e Cry1Ac, respectivamente (Hossain, D.M. et al., 2004). Adicionalmente, uma GPI- $\alpha$-glicosidase de A. albimanus e uma metaloprotease (ADAM-3) de T. molitor, foram identificadas como ligantes para as toxinas Cry4Ba e Cry3Aa, respectivamente (Fernandez-Luna, M.T. et al., 2010; Ochoa-Campuzano, C. et al., 2007).

\subsubsection{Caderinas}

As caderinas pertencem a uma superfamília de proteínas transmembrana dependentes de cálcio, com uma alta variedade e diversidade de funções, desde a adesão celular até a morfogênese (Pettitt, J., 2005). São proteínas filamentosas compostas estruturalmente por domínios repetidos (CRs - cadherin repeats) com cerca de 110 resíduos de aminoácidos cada domínio. Caderinas normalmente apresentam cerca de cinco CRs, entretanto, já foram descritas caderinas com até 34 CRs (Angst, B.D., Marcozzi, C. \& Magee, A.I., 2001; Dunne, J. et al., 1995). Estes domínios são formados por um sanduíche $\beta$ com folhas- $\beta$ antiparalelas que assumem uma topologia do tipo chave-grega (Jin, X. et al., 2012) e estão conectados entre si por alças e nas junções entre CRs adjacentes estão presentes os sítios de ligação ao cálcio, que formam uma haste rígida e conferem estabilidade à proteína (Gonzalez-Reyes, A., 2003). A primeira caderina identificada como ligante de uma toxina Cry foi isolada de Manduca sexta e 
denominada de BT-R 1 (Vadlamudi, R.K., Ji, T.H. \& Bulla, L.A., Jr., 1993). Posteriormente, esta proteína foi clonada, sequenciada e validada como receptor para a toxina Cry1 Ab (Vadlamudi, R.K. et al., 1995).

Por meio de ensaios de ligação com BT-R $\mathrm{R}_{1}$ expressa em sistemas heterólogos de mamífero e inseto foi possível demonstrar que este receptor liga-se igualmente às Cry1Aa e Cry1Ac. Paralelamente, foi demonstrado que Cry1Aa e Cry1Ac inibem a ligação da Cry1 Ab (Lucena, W.A., 2012). Outra caderina foi isolada de Bombxy mori (BtR175) e validada como um receptor para a Cry1Aa (Nagamatsu, Y. et al., 1999). A BtR175 apresenta uma identidade de $70 \%$ na sequência de aminoácidos com a caderina isolada de Manduca sexta (BT-R $)_{1}$ e uma afinidade de ligação de 4,0 nM com a Cry1Aa. Além disso, similarmente à $\mathrm{BT}^{-\mathrm{R}_{1}}$, as outras toxinas Cry1 Ab e Cry1Ac competem pelo sítio de ligação da Cry1Aa (Tsuda, Y. et al., 2003).

Estudos com populações de Heliothis virescens resistentes à Cry1Ac possibilitaram a identificação de uma terceira caderina (Gahan, L.J., Gould, F. \& Heckel, D.G., 2001), posteriormente denominada de HevCaLP e confirmada como receptor para as Cry1Aa, Cry1Ab e Cry1Ac, com diferentes afinidades de ligação (Jurat-Fuentes, J.L. \& Adang, M.J., 2006; Jurat-Fuentes, J.L. et al., 2004; Xie, R. et al., 2005).

Até o presente momento, cerca de 60 sequências nucleotídicas e 47 sequências proteicas de caderinas receptoras ou ligantes, de pelo menos uma toxina Cry, estão depositadas no National Center of Biotechnological Information (NCBI), isoladas de 13 espécies de insetos-alvo: Manduca sexta (BT-R 1 , Bomboyx mori (BtR175), Heliothis virescens (HevCaLP), Tricoplusia ni, Helicoverpa armigera, Tenebrio molitor, Plutella xylostella, Ostrinia nubialis, Pectinophora gossypiella, Chilo suppressalis, Limantria dispar, Agrotis ipsilon, Spodoptera frugiperda e Aedes aegypti (Lucena, W.A., 2012) 
Os íons de $\mathrm{Ca}^{2+}$ tem importante função alostérica no mecanismo adesivo das caderinas (Sotomayor, M. \& Schulten, K., 2008). Por serem proteínas filamentosas e em sua maioria grandes, as caderinas são permissíveis de se dobrar e aglutinar, dificultando a interação com outras caderinas e impossibilitando a adesão entre células. Acontece que isso também possibilita um maior controle para as células, uma vez que pode haver vantagens e desvantagens a se considerar para participar em adesão celular (Perez, T.D. \& Nelson, W.J., 2004). O mecanismo pelo qual as células "ativam" suas caderinas para que estas exerçam sua função adesiva é por meio da presença de íons $\mathrm{Ca}^{2+}$ na matriz extracelular.

E um estudo usando dinâmica molecular, foram analisadas as diferença de flexibilidade de uma caderina ligada a íons de cálcio e na ausência desses (Sotomayor, M. \& Schulten, K., 2008). Ficou claro que a caderina ligada a íons de $\mathrm{Ca}^{2+}$ é estável e tem uma estrutura mais enrijecida comparada à caderina simulada apenas em água. Esse foi o primeiro trabalho exemplificando dinamicamente a regulação alostérica do íons de cálcio no controle do enrijecimento e adesão celular mediada por caderinas. Antes disso caderinas epiteliais de camundongo haviam sido cristalizadas na presença de cálcio e suas estruturas caracterizadas (Nagar, B. et al., 1996). As regiões de ligação aos íons de cálcio são conservadas em grande parte das caderinas e localizam-se entre os repetidos domínios extracelulares (CRs) (Brasch, J. et al., 2012).

Enquanto múltiplos alelos de resistência podem ser identificados nos genes codificando o receptor primário caderina, experimentos mostram que mutações afetando os receptores secundários, de alta afinidade à toxinas Cry, não induzem resistências à essas toxinas. 


\subsubsection{Evolução}

Diante dessa gama de toxinas, que apresentam tamanha diversidade de alvos, torna-se necessário tentar explicar como as diferentes cepas de Bt vieram a produzir toxinas com estrutura e função tão semelhantes, mas sequência de aminoácidos e mecanismos de ação tão diferentes. A melhor forma de tentar compreender a evolução de toxinas Cry é separá-las baseando-se em quatro possíveis mecanismos: transferência de plasmídeos, recombinação, adaptação evolutiva (mutações) e transposons (de Maagd, R.A. et al., 2003; Palma, L., Munoz, D., Berry, C., et al., 2014).

A maioria das cepas de Bt carregam extensos plasmídeos contendo genes codificadores de toxina em seu repertório (Agaisse, H. \& Lereclus, D., 1995; Berry, C. et al., 2002; Loeza-Lara, P.D. et al., 2005; Mesrati, L.A., Tounsi, S. \& Jaoua, S., 2005). O consenso científico é de que esses plasmídeos não promovem mobilização de maneira independente, uma vez que ainda não há evidencias suficientes sobre seus mecanismos de transferência. A exceção é o sistema de transferência mediada por conjugação, descrito para o plasmídeo pX016 de Bt, que é capaz de mobilizar plasmídeos codificando toxinas entre cepas de Bt (Andrup, L. et al., 1996; Jensen, G.B. et al., 1996) e entre Bt e Ls (Gammon, K. et al., 2006). A transferência de plasmídeos também foi relatada dentro de larvas infectadas (Jarrett, P. \& Stephenson, M., 1990), no solo (Thomas, D.J.I. et al., 2000), rios (Thomas, D.J.I. et al., 2001) e superfície foliar (Gonzalez, J.M., Jr., Brown, B.J. \& Carlton, B.C., 1982). A combinação de plasmídeos entre cepas tranconjugantes também foi usada para comercialização de produtos (Tabela 2) e indica que plasmídeos de cepas diferentes podem ser compatíveis (Palma, L., Munoz, D., Berry, C., et al., 2014). O movimento de plasmídeos na natureza pode ser responsável pela descoberta de genes cry em espécies que não Bt, como em Ls (Jones, G.W. et al., 2007), Paenibacillus popilliae (Zhang, J. et al., 1997), Paenibacillus lentimorbus (Yokoyama, T., Tanaka, M. \& Hasegawa, M., 2004) e Clostridium bifermentans (Barloy, F. et al., 1996), bem como a presença de genes cyt-relacionados em Erwinia e Dickea daddanii (Costechareyre, D. et al., 2010; Rigden, D.J., 2009). A transferência de plasmídeos pode explicar porque diferentes cepas de Bt, distribuídas em regiões geograficamente distintas, possuem cópias idênticas de um mesmo gene cry (Murawska, E., Fiedoruk, K. \& Swiecicka, I., 2014; Palma, L., Munoz, D., Murillo, J., et al., 2014). 
Tanto genes cry quanto vip são sujeitos à forças evolucionárias de adaptação que direcionam sua evolução e especificidade (Wu, J. et al., 2007; Wu, J.Y. et al., 2007). Estudos filogenéticos sugerem que os genes que codificam as toxinas da família 3D-Cry evoluíram de um ancestral comum e que sua diversidade é impulsionada por mutações e recombinação homóloga (de Maagd, R.A. et al., 2003). Embora a nomenclatura de toxinas Cry (http://www.btnomenclature.info) (Crickmore, N. et al., 2014) seja feita utilizando a estrutura primária de protoxinas, o resultado da análise filogenética é diferente quando feita com a sequência de toxinas ativas (Figura 13), revelando diferentes relações entre famílias de certas toxinas Cry (Bravo, A., 1997; Bravo, A. et al., 2013; Crickmore, N., 2000; de Maagd, R.A., Bravo, A. \& Crickmore, N., 2001). Por exemplo, Cry9Aa ativa (fragmento) não apresenta qualquer relação evolucionária com os fragmentos de Cry9Ba e Cry9Ca, indicando que a alta identidade de sequência da extensão C-terminal das respectivas protoxinas (toxina inteira) é a responsável pelo agrupamento conjunto entre essas toxinas (Bravo, A. et al., 2013). Uma análise filogenética mais detalhada, com base nos três domínios individuais (de Maagd, R.A., Bravo, A. \& Crickmore, N., 2001), mostra que o domínio III de Cry9Aa tem a mesma origem que os domínios III das outras toxinas Cry9 (Ba, Ca, Da e Ea), enquanto o domínio I tem uma origem única e o domínio II uma similaridade com Cry24Aa (Figura 15).

Essas informações enfatizam a contribuição da extensão C-terminal para a classificação das toxinas na atual nomenclatura, pois nem a mesma origem de um dos domínios (III) foi capaz de agrupar o fragmento da toxina Cry9Aa junto à sua família. O interessante é que a relação filogenética usando fragmentos de toxina gerou um agrupamento baseado na especificidade das toxinas à ordens de insetos alvos, com algumas exceções. Cry1B e Cry1I, que apresentam toxicidade específica à lepidópteras, foram agrupadas com Cry3, Cry7 e Cry8, que são tóxicas à coleópteras (Bravo, A., 1997; Crickmore, N., 2000). Essa observação sugeria ser possível que proteínas da família Cry1I e Cry1B apresentassem toxicidade para coleópteras, o que foi posteriormente confirmado para ambas proteínas (Grossi-de-Sa, M.F. et al., 2007; Lopez-Pazos, S.A., Cortazar Gomez, J.E. \& Ceron Salamanca, J.A., 2009; Martins, E.S. et al., 2008). Dessa maneira, conclui-se que as relações filogenéticas usando sequências de protoxinas não revelam como evoluiu a especificidade das toxinas Cry (Bravo, A. et al., 2013). 

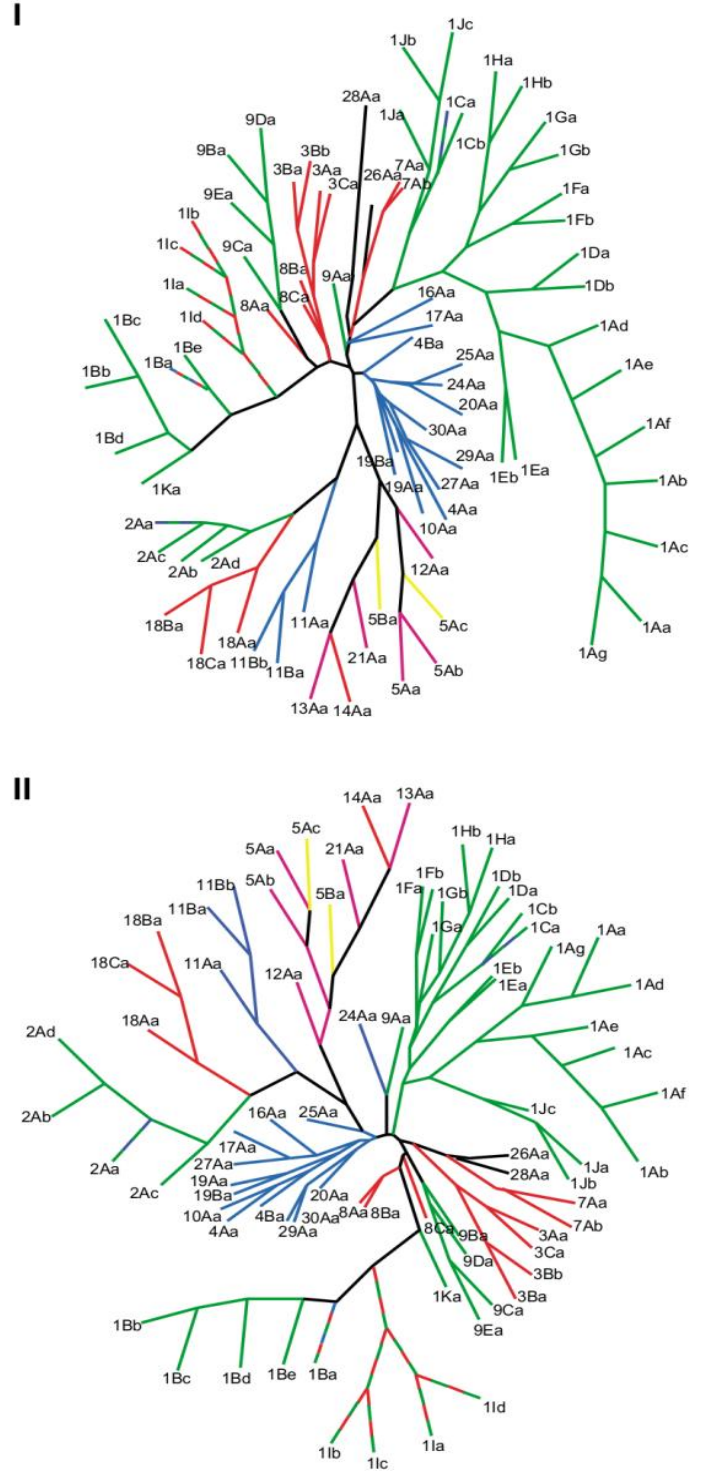

III

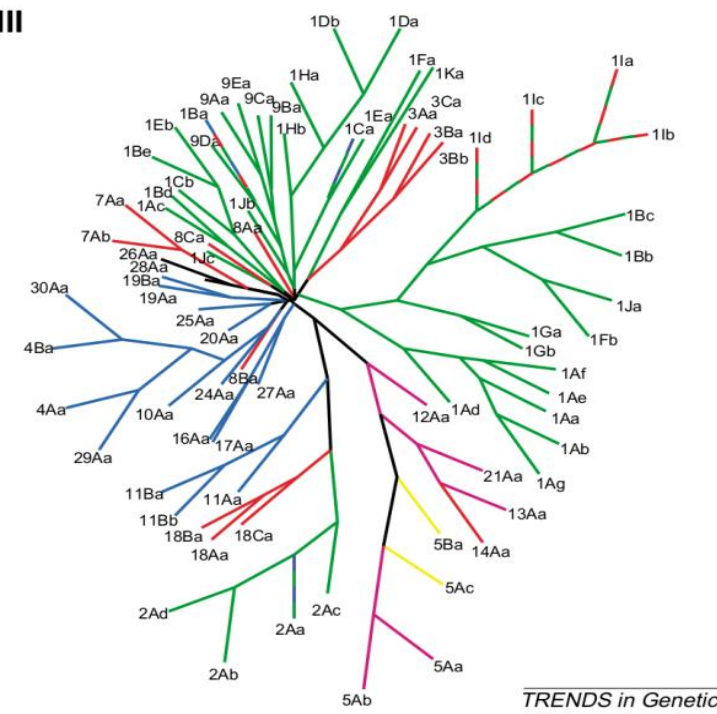

Figura 15: Relação filogenética de domínios individuais. Os troncos foram coloridos de acordo com a ordem de insetos-alvo especificamente alvejada pelas toxinas: em vermelho, toxinas específicas a coleópteras; verde, específicas a lepidópteras; azul, específicas a dípteras; magenta, específicas a nematoides; e amarelo, específicas a himenópteras.

(de Maagd, R.A., Bravo, A. \& Crickmore, N., 
As toxinas da família 3D-Cry possuem algumas regiões com identidade significativa (Crickmore, N. et al., 1998), particularmente em cinco blocos conservados na sequência das toxinas ativas (Hofte, H. \& Whiteley, H.R., 1989), e três blocos conservados espalhados pela extensão C-terminal de grandes protoxinas (Schnepf, E. et al., 1998)(Figura 13). Postula-se que essas regiões de conservação facilitam a recombinação entre os genes das toxinas. A ocorrência de tais rearranjos é corroborado pela aparente diferença nas taxas de evolução quando se analisa cada um dos três domínios (de Maagd, R.A., Bravo, A. \& Crickmore, N., 2001)(Figura 15).

Domínio I e domínio II aparentam ter coevoluído pois apresentam árvores filogenéticas estruturalmente similares, com as principais ramificações correspondendo a um mesmo grupo de especificidade (ou toxicidade) à insetos. As árvores utilizando esses dois domínios também são muito similares às arvores geradas usando os fragmentos de toxinas (ativas), onde as famílias Cry1I e Cry1B e as toxinas Cry1Ka e Cry9Aa se encontram distantes dos grupos que lhe dão nome (Figura 15). Aparentemente, a coevolução desses dois domínios é quem direciona a especificidade de uma toxina a um dado inseto. Uma observação que corrobora com isso é que as ramificações da família Cry1I e a toxina Cry1Ba, ambas com toxicidade descritas para coleópteros e lepidópteros, encontram-se entre ramificações puramente específicas à coleópteros e lepidópteros (Figura 15).

Já a topologia da árvore filogenética baseada no D-III aparenta ter uma maior conservação da especificidade de toxinas à uma dada ordem de inseto. Observa-se que, com exceção das famílias tóxicas à coleópteros e da família Cry2, o restante dos grupos de especificidade (Lepidóptera, Díptera e Nematódea) estão mais uniformemente agrupados (Figura 15). Isso corrobora com o fato deste domínio possuir três blocos de sequências conservadas e ser o domínio com menos diversidade estrutural entre as toxinas 3D-Cry. No entanto, quando analisamos o D-III dentro de uma mesma família de toxinas nota-se uma maior promiscuidade. Por exemplo, Cry1Ac e Cry1Bd compartilham um D-III similar e de origem diferente ao de outras toxinas Cry1A e Cry1B. O mesmo é visto entre as toxinas Cry1Be, Cry1Cb e Cry1Eb, que possuem DIII de mesma origem (Bravo, A. et al., 2013). Com base nessas informações foi proposto o mecanismo de "rearranjo do domínio III" para a evolução de toxinas Cry. Exemplos desse mecanismo podem ser vistos na Figura 16. Esse mecanismo implica, portanto, que o terceiro bloco conservado nas sequências de toxinas ativas é mais 
propenso a sofrer recombinação, uma vez que ele está localizado na interface entre domínio II e III (Figura 13). Isso pode, por sua vez, ter alguma implicação na organização dos genes cry.

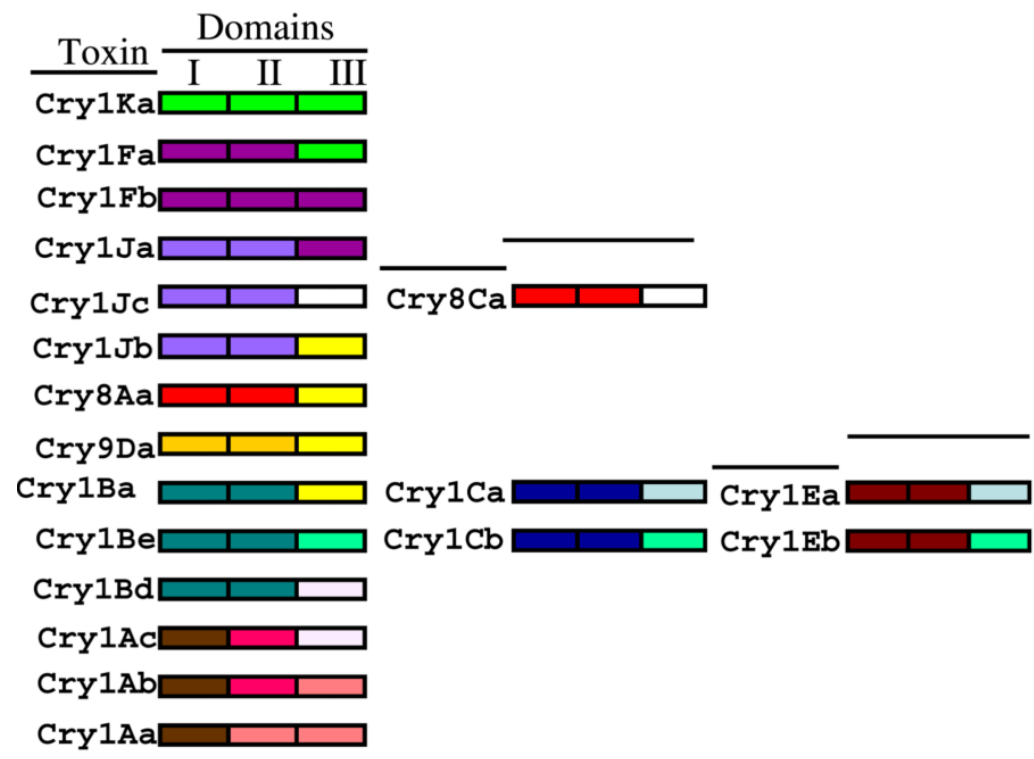

(Bravo, A. et al., 2011)

Figura 16: Exemplos naturais do rearranjo do domínio III. Cores representam similaridade de sequência de aminoácidos entre os três domínios de toxinas Cry.

Um trabalho visando a estudar a adaptação evolutiva em genes cry mostrou que alguns resíduos de aminoácidos de toxinas 3D-Cry estão sob seleção positiva (Wu, J.Y. et al., 2007), assim como a região C-terminal da toxina Vip3 (Wu, J. et al., 2007). A seleção positiva favorece a retenção de mutações que são benéficas a um individuo ou população. Vinte e quatro resíduos de 3D-Cry foram identificados sob seleção positiva e a maioria estão localizados nas regiões de loop (alças) do domínio II ou no domínio III, sugerindo que estas regiões possam estar envolvidas no reconhecimento de receptores. Baseado nessa observação, foi proposto que a alta divergência de sequências nessas regiões pode promover a rápida evolução aos receptores de insetos-alvo (Wu, J.Y. et al., 2007).

A sequência do plasmídeo pBtoxis do Bti revela algumas características interessantes (Berry, C. et al., 2002). Seis dos sete genes de toxinas contidos nesse plasmídeo estão agrupados em uma região de aproximadamente 30-kb, dos 129-kb referente a sequência do plasmídeo inteiro. Por um lado isso pode permitir uma maior 
taxa de recombinação devido à proximidade de genes individuais. Por outro, não há evidências de que essa região seja uma "ilha de patogenicidade" dentro do plasmídeo, já que as toxinas aparentam ser flanqueadas por sequências de transposons, o que, portanto, sugere que cada gene tenha sido adquirido independentemente. Gonzales e Carlton demonstraram que esse plasmídeo tem potencial para se rearranjar e recombinar com outros plasmídeos de formas diferentes, desde que submetido em uma cultura à 42 ${ }^{\circ} \mathrm{C}$ (González Jr, J. \& Carlton, B.C., 1984). Além dos genes completos de toxinas, esse plasmídeo carrega o que aparenta ser fragmentos vestigiais de sequências codantes de toxinas (Berry, C. et al., 2002). Isso pode ser evidência da evolução de toxinas e pode representar fragmentos de genes que foram deixados para trás após eventos de recombinação ou transposição, pois cada fragmento vestigial possui uma sequência de transposon em sua proximidade (de Maagd, R.A. et al., 2003).

Por fim, a maioria dos genes de toxina Bt estão localizados próximos a sequências relacionadas com transposição (Mahillon, J. et al., 1994). Isso proporciona meios óbvios para a mobilização de sequências de toxinas entre plasmídeos e genoma do hospedeiro, bem como permite a montagem de novas combinações de genes cry dentro de uma mesma cepa de Bt (de Maagd, R.A. et al., 2003).

Embora existam vários fatores que podem contribuir para a habilidade do $\mathrm{Bt} \mathrm{em}$ amplificar a diversidade de suas toxinas, parece haver um limite para as variações de uma mesma toxina. Almond e Dean mostraram que muitas variantes quiméricas da família Cry1A, geradas por recombinação, são sensíveis à degradação por proteases de bactérias (Almond, B.D. \& Dean, D.H., 1994). O fato de que a maioria dos genes identificados na natureza codificam toxinas com atividade sugere uma forte pressão seletiva para que estas mantenham sua atividade, embora esse mecanismo de seleção ainda não esteja claro.

\subsubsection{Regulação Gênica}

As primeiras regulações gênicas ocorrerem no nível transcricional e no caso das toxinas Cry podemos dividi-la em dois tipos, de acordo com o mecanismo: dependentes de esporulação, onde genes cry são controlados pelos fatores sigma SigK e/ou SigE; e independente de esporulação, onde genes cry estão sob controle do fator de crescimento vegetativo SigA (Agaisse, H. \& Lereclus, D., 1995). 
A esporulação nas espécies de Bacillus inicia com a divisão assimétrica da célula em duas partes: a célula-mãe e o endósporo primordial (Figura 1 e Figura 17). No organismo modelo, $B$ subtillis (Bs), esse processo é regulado espacialmente e temporalmente por um conjunto de fatores para RNA polimerases: os fatores sigma vegetativos, SigA e SigH, durante a fase anterior à divisão assimétrica; SigE e SigK, na célula mãe; e SigF e SigG, no endósporo primordial (Piggot, P.J. \& Hilbert, D.W., 2004). Fatores sigma homólogos (SigA, SigH, SigE, SigK, SigF e SigG) foram descritos em Bt e assume-se que o processo de esporulação em Bt é basicamente o mesmo de Bs (Aronson, A., 2002; Lereclus, D. \& Agaisse, H., 2000; Wang, J. et al., 2013). Muitos dos genes cry foram definidos como dependentes de esporulação por terem sua transcrição controlada principalmente pelos fatores sigma específicos da célula-mãe, SigE e SigK. São os casos dos genes cryl (Bravo, A. et al., 1996; Yang, H. et al., 2012), cry4 (Dervyn, E. et al., 1995; Piggot, P.J. \& Hilbert, D.W., 2004; Yoshisue, H. et al., 1995), cry8 (Du, L. et al., 2012), cryl (Poncet, S. et al., 1997) $e$ cryl8 (Zhang, J. et al., 1998).

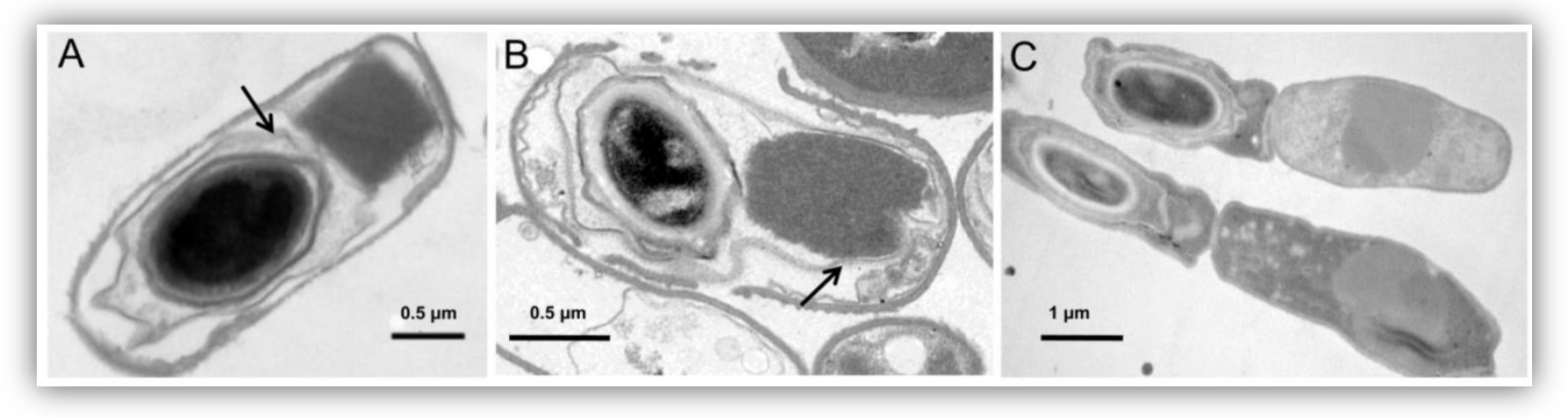

(Deng, C. et al., 2014)

Figura 17: Diferentes padrões na produção de inclusões cristalinas em Bt. (A) Cepa D73 com o fenótipo típico, produzindo o esporo na célula-mãe. (B) Cepa YBT-020, o cristal é produzido entre o exoesporium e o invólucro esporal. (C) Cepa LM1212, o cristal é produzido em diferentes subpopulações celulares. As setas indicam o exosporo.

A transcrição é iniciada por SigE no estágio inicial da esporulação e continuada por SigK no estágio tardio (Lereclus, D. \& Agaisse, H., 2000). A ativação sucessiva destes dois fatores sigma na célula-mãe assegura uma transcrição intensa e contínua dos genes cry, o que permite a produção massiva de proteínas Cry durante a esporulação (Deng, C. et al., 2014). A transcrição de uma minoria de genes dependentes de esporulação, notavelmente cry15A e cry2, é controlada apenas por SigE (Brown, K.L., 
1993; Widner, W.R. \& Whiteley, H.R., 1989). Logo, estes genes são expressos por um período relativamente menor que genes regulados ambos por SigE e SigK (Aronson, A., 2002). A transcrição do gene sigE, por sua vez, é estimulada quando há uma alta expressão induzida (superexpressão) de polifosfato quinase (PPK). Como esperado, constataram que a superexpressão de PPK também aumenta indiretamente a produção de proteínas Cry reguladas por SigE (Doruk, T. et al., 2013).

Alguns dos genes cry citados acima $(1,4,8$ e 11$)$ também podem ser fracamente expressos ao final da fase vegetativa devido à iniciação da transcrição pelo fator sigma vegetativo SigH (Du, L. et al., 2012; Pérez-García, G., Basurto-Ríos, R. \& Ibarra, J.E., 2010; Poncet, S. et al., 1997; Yoshisue, H. et al., 1995). A região promotora ao qual SigH se liga nesses genes está localizada à montante dos promotores dependente de SigE e SigK em crylAc (Pérez-García, G., Basurto-Ríos, R. \& Ibarra, J.E., 2010); sobreposto ao promotor dependente de SigE em cry4 e cryll (Poncet, S. et al., 1997; Yoshisue, H. et al., 1995); e na região intergênica entre a CDS de cry $8 E$ e um gene à montante, chamado orfl (Du, L. et al., 2012). Portanto, não existe um modelo único que descreva a regulação da transcrição para todos os genes cry e os diversos padrões de expressão observados durante a esporulação dependem da combinação de promotores (Deng, C. et al., 2014).

A proteína Spo0A é a principal reguladora da célula para o inicio da esporulação em Bs (Molle, V. et al., 2003). A forma fosforilada de Spo0A (Spo0A-P) se liga à uma sequência de DNA conhecida como "0A-box" e atua tanto como repressor de alguns genes expressos no crescimento vegetativo, quanto como ativador de genes específicos à esporulação (Molle, V. et al., 2003). A regulação temporal e espacial de genes durante a esporulação de Bt é similar à de Bs, e a proteína Spo0A de Bt e Bs são homólogas (Lereclus, D. et al., 1995). Além disso, sequências de DNA similares ao "0A-box" foram encontradas à montante de alguns genes cry $(4 A, 4 B$ e $11 A)$ em Bti (Poncet, S. et al., 1997). Aparentemente, Spo0A pode regular negativamente (reprimir) e positivamente (ativar) a expressão de genes cry dependentes de esporulação, como foi mostrado para cryllA e crylAc, respectivamente (Poncet, S. et al., 1997; Yang, H. et al., 2012). No entanto, em todos os casos a expressão de genes esporulantes foi bem mais reduzida em mutantes de spoOA do que na cepa selvagem. Isso indica que a proteína Spo0A apresenta funções diferentes durante a fase de transição comparado à esporulação, onde na primeira exerce uma modulação moderada (ativação e repressão) e 
na última uma ativação mais intensa de fatores sigma específicos à genes dependentes de esporulação (Deng, C. et al., 2014).

Diferentemente dos genes dependentes de esporulação, a transcrição do gene cry3 inicia-se durante o final do crescimento vegetativo e continua por algumas horas durante a fase estática. Ele é regulado pelo promotor vegetativo de SigA e sua expressão é maior em mutantes spoOA e spoOF, ambos defectivos para esporulação, do que em cepas selvagens (Agaisse, H. \& Lereclus, D., 1994a, 1995; Lereclus, D. et al., 1995; Malvar, T. \& Baum, J.A., 1994). Até a descoberta de uma cepa incomum de Bt, os genes cry3 eram os únicos exemplos de genes cry independentes de esporulação (Deng, C. et al., 2015).

A cepa LM1212 apresenta um fenótipo único e bastante intrigante: em sua população existe a diferenciação entre células produtoras de esporo e células produtoras de cristais. Portanto, os cristais de toxinas são produzidos em uma subpopulação de células que não esporulam, ao invés de no compartimento da célula-mãe de células esporulantes (Figura 17). A análise transcricional dos genes cry LM1212 revelou uma expressão temporal similar à de cry3. O mais interessante foi a descoberta de que existem subpopulações não esporulantes em todas as espécies de Bacillus que transcrevem os genes cry LM1212, mas essa subpopulação é muito menor em outras cepas que não a LM1212. (Deng, C. et al., 2015) Além disso, os genes cry LM1212 não são controlados pelos fatores sigma dependentes de esporulação, SigE e SigK, e tratamse de genes independentes de esporulação controlados por um novo mecanismo transcricional (Deng, C. et al., 2014).

Outros mecanismos que regulam a expressão de genes cry são as sequências de repetição invertida, como as encontradas em genes crylA, e a estabilização do RNA mensageiro por moléculas protetoras (Agaisse, H. \& Lereclus, D., 1994b, 1995, 1996; Mathy, N. et al.; Wong, H.C. \& Chang, S., 1986). 


\subsection{Justificativa}

A crescente evolução de resistência à cultivares Bt nas lavouras foi documentada para pelo menos 13 espécies diferentes de insetos (Tabashnik, B.E., Brevault, T. \& Carriere, Y., 2013). Uma alternativa para a busca e isolamento de novas cepas de Bt na natureza é a evolução genética in vitro e engenharia ab inito de toxinas Cry, almejandose aumentar a toxicidade contra pestes específicas, matar novos alvos ou recuperar a toxicidade no caso de surgir resistência na agricultura (Pardo-Lopez, L. et al., 2009).

Vários grupos de pesquisa têm concentrado esforços durante as últimas três décadas para elucidar aspectos relativos ao mecanismo de ação das $\delta$-endotoxinas no nível molecular, desde a contribuição efetiva de cada domínio ou fragmento das toxinas até os eventos conformacionais e interações destas com a membrana intestinal, que ocorrem desde a ativação da protoxina até a morte celular. O resultado deste esforço é uma vasta produção bibliográfica que versa sobre o tema com muitas evidências experimentais, obtidas por diversas metodologias. Todavia, é importante observar que parte dos dados disponíveis na literatura está fora de sincronia, muitas vezes difícil de serem comparados e são pouco conclusivos. Neste âmbito, é importante haver compilações que fornecem uma visão geral dos mecanismos propostos para explicar o modo de ação e também a interação das toxinas com moléculas dos insetos-alvo.

Tradicionalmente, o desenvolvimento de biopesticidas baseados em toxinas Cry tem dependido da amostragem de toxinas, com atividade para uma dada pestes-alvo, por meio de isolados naturais de B. thuringiensis. Devido à sua importância agronômica como pesticida, há tempos almeja-se desenvolver um método para a engenharia de toxinas Cry com atividade inseticida aprimorada e que apresentem um menor espectro de pragas-alvo. Enquanto a controvérsia permanece em relação ao modo de ação do mecanismo citotóxico das toxinas Cry, este trabalho procura caracterizar o modo de ação pelo qual toxinas Cry se ligam ao receptor primário tipo caderina, BT- $\mathrm{R}_{1}$. Argumenta-se que a ligação a esse tipo de receptor é descrita como crucial para o desenrolar de eventos que culminam na perda da $\alpha$-hélice 1 e subsequente morte celular, bem como é nessa etapa em que a especificidade ao inseto está mais claramente definida. 


\subsection{Objetivo Geral}

O objetivo geral deste trabalho é propor um modelo estrutural capaz de comparar os dados prévios da literatura e inferir novas hipóteses para a interação entre as toxinas da família Cry1 A e o receptor tipo caderina BT- $\mathrm{R}_{1}$.

\subsection{Objetivos Específicos}

- Identificar as interações in silico entre receptor e ligante nos modelos obtidos.

- Relacionar as regiões de ligação dos modelos com as regiões putativas de outras toxinas da família Cry1A e outros receptores tipo caderina.

- Sugerir quais regiões da toxina são responsáveis por determinar sua especificidade ao receptor e utilizar essas regiões em uma análise evolutiva para entender como as toxinas 3D-Cry adquiriram toxicidade à tantas ordens de insetos e de maneira tão específica.

- Avaliar se o modelo é corroborado em experimentos in-vitro e selecionar o modelo mais provável para ser utilizado em um futuro banco de dados para engenharia de toxinas Cry.

- Organizar de maneira concisa os mais de 100 anos dedicados a pesquisa com Bacillus thuringiensis e suas toxinas em uma revisão. 


\section{Capítulo 2}

\section{Modelagem por Homologia}

\section{e Docking}

DAS UTOPIAS

Se as coisas são inatingíveis... ora!

Não é motivo para não querê-las...

Que tristes os caminhos, se não fora

A presença distante das estrelas!

- Mário Quintana 


\subsection{Conceito}

\subsubsection{Modelagem por Homologia}

A técnica de Modelagem por Homologia $(\mathrm{MpH})$, ou modelagem comparativa, consiste em criar um modelo tridimensional de resolução atomística para uma proteínaalvo a partir de sua sequência de aminoácidos. Para isso é necessário uma estrutura de referência (template, ou molde), a qual a sequência de aminoácidos da molécula-alvo será alinhada. Quanto maior a identidade de aminoácidos entre a molécula-alvo e a referência, melhor é a acurácia e qualidade do modelo. Dessa maneira, os aminoácidos da molécula-alvo são mapeados para as coordenadas cartesianas dos aminoácidos aos quais cada um está alinhado na estrutura de referência, ou seja, recebem a localização tridimensional dos aminoácidos templates. O conceito por trás disso é que as estruturas proteicas são mais facilmente conservadas do que a sequência de aminoácidos, entre duas proteínas homólogas. No entanto, estruturas de referência que contenham menos de $20 \%$ de identidade com a molécula-alvo podem não representar essa conservação de estrutura e, portanto, apresentar estrutura tridimensional distinta.

\subsubsection{Docking Molecular}

A técnica de docking molecular (DM) pode ser usada para modelar a interação atômica entre macromoléculas, o que nos permite caracterizar o comportamento de moléculas no sítio de ligação de proteínas, bem como elucidar processos bioquímicos fundamentais (Brooijmans, N. \& Kuntz, I.D., 2003; Morris, G. \& Lim-Wilby, M., 2008). O processo de docking envolve dois passos básicos: a predição das conformações, posições e orientações do ligante dentro do sítio ativo (usualmente conhecido como "pose") e a avaliação da afinidade de ligação (usualmente medida por meio de energia livre). Esses dois passos estão relacionados com métodos de amostragem e sistemas de pontuação, respectivamente (Meng, X.Y. et al., 2011).

A primeira explicação para o mecanismo de ligação entre receptor e ligante foi a teoria de chave-fechadura proposta por Fischer (Fischer, E., 1894), em que o ligante se encaixa no receptor da mesma forma que uma chave cabe uma fechadura. Os primeiros métodos computacionais de docking relatados (Kuntz, I.D. et al., 1982) foram baseados nessa teoria e ambos receptor e ligante foram adequadamente tratados como corpos rígidos. Depois a teoria de "encaixe induzido" (Hammes, G.G., 2002; Koshland, D.E., 
Jr., 1963), criada por Koshland, levou a teoria de chave-fechadura um passo adiante, afirmando que o sítio ativo de proteínas estão continuamente sendo remodelados por interações com o ligante enquanto este interage com a proteína. Essa teoria sugere que o ligante e o receptor devem ser tratados como flexíveis durante um docking. Consequentemente, isso poderia descrever os eventos de ligação com mais precisão que um tratamento rígido (Kitchen, D.B. et al., 2004; Meng, X.Y. et al., 2011).

Essencialmente, o objetivo do DM é predizer a estrutura do complexo receptor ligante usando métodos computacionais (Kitchen, D.B. et al., 2004). O docking pode ser alcançado por meio de duas etapas inter-realcionadas : primeiro selecionando as poses (conformações) do ligante no sitio ativo da proteína; e depois ranqueando essas poses por meio de uma função de pontuação (Morris, G. \& Lim-Wilby, M., 2008). Idealmente, os algoritmos de amostragem devem ser capazes de reproduzir a pose com modo de ligação experimental e a função de pontuação deve ser capaz de ranqueá-la como o melhor entre todas as poses geradas.

\subsection{Material \& Métodos}

\subsubsection{Obtenção de modelos por homologia de sequência}

Para este estudo, foram selecionadas as sequências de Cry1 Ab (AEV45790.1) e BT-R 1 (AAG37912.1) depositadas no banco de proteínas do NCBI (Anexo 1 da Seção I). O primeiro passo antes de iniciar a modelagem é gerar uma predição da estrutura secundária da sequência de resíduos de aminoácidos da proteína de interesse. É ideal fazer três predições para se obter um consenso. Os três servidores usados para gerar a predição de estrutura secundária de todas as proteínas deste trabalho foram PSIPRED (http://bioinf.cs.ucl.ac.uk/psipred/) (Buchan, D.W. et al., 2013), Phyre 2.0 (www.sbg.bio.ic.ac.uk/ phyre2/) (Kelley, L.A. \& Sternberg, M.J.E., 2009) e Jpred4 (http://www.compbio.dundee.ac.uk/jpred4/) (Cole, C., Barber, J.D. \& Barton, G.J., 2008). Além disso foi obtido uma predição da fronteira entre domínios usando o servidor ThreaDom Online (http://zhanglab.ccmb.med.umich.edu/ThreaDom/ )(Xue, Z. et al., 2013).

Com base nas predições de estrutura secundária e domínios, a sequência de aminoácidos das proteínas foram fragmentadas da seguinte maneira: inteira (sequência completa), domínios e grupos de estrutura secundária (e.g. apenas regiões de $\alpha$-hélices, 
apenas regiões de folhas- $\beta$, regiões com mistura de estruturas $\alpha$ e $\beta$ ). Todos esses fragmentos de sequência foram então submetidos individualmente aos servidores de modelagem automática: LOMETS (http://zhanglab.ccmb.med.umich.edu/LOMETS/) (Wu, S. \& Zhang, Y., 2007), SWISS-MODEL (http://swissmodel.expasy.org/) (Biasini, M. et al., 2014; Kiefer, F. et al., 2009), M4T 3.0 (http://manaslu.aecom.yu.edu/M4T/) (Fernandez-Fuentes, N. et al., 2007) e para o servidor QUARK (http://Zhanglab.ccmb.med.umich.edu/QUARK/) (Xu, D. \& Zhang, Y., 2012). Desses, apenas o QUARK faz a modelagem de estrutura ab initio (sem estrutura template), o restante utiliza a técnica de modelagem por homologia.

Todos os modelos, relativos a todos os fragmentos, foram analisados quanto aos seus ângulos phi $(\Phi)$ e psi $(\Psi)$ em gráficos de Ramachandran gerados pelo servidor RAMPAGE (http://mordred.bioc.cam.ac.uk/ rapper/rampage.php) (Lovell, S.C. et al., 2003) e quanto ao erro local dos resíduos de aminoácidos no servidor ProSA-Web (https://prosa.services.came.sbg.ac.at/prosa.php) (Wiederstein, M. \& Sippl, M.J., 2007).

Todos os modelos apresentando $<2 \%$ de ângulos $\Phi$ e $\Psi$ em posição proibida, estrutura secundária condizente com as predições e/ou modelos apresentando Z-score dentro da região permitida, de acordo com o ProSA, foram selecionados para modelagem usando o programa MODELLER v9.11 (Webb, B. \& Sali, A., 2014a, 2014b) por meio de um script e um arquivo de alinhamento (Anexo 1 da Seção I). Para cada um desses modelos selecionados, foi selecionado também o respectivo template que lhe deu origem, fornecido pelos servidores de modelagem automática. As sequências de cada fragmento e templates selecionados foram alinhadas usando o MUSCLE (http://www.ebi.ac.uk/Tools/msa/muscle/) (Edgar, R.C., 2004). Esse alinhamento (Anexo 1 da Seção I) e os arquivos PDB referentes a cada sequência nele contido foram usados em diversas combinações para produção de modelos inteiros e/ou pedaços truncados da proteína-alvo. Um modelo do script utilizado no MODELLER para produção desses modelos pode ser visto no Anexo 1 da seção I. Os modelos $\begin{array}{lllll}\text { produzidos foram todos analisados no servidor QMEAN } & \text { Q }\end{array}$ (http://swissmodel.expasy.org/qmean/cgi/index.cgi ) (Benkert, P., Kunzli, M. \& Schwede, T., 2009; Benkert, P., Tosatto, S.C. \& Schomburg, D., 2008) e Molpropity (http://molprobity.biochem.duke.edu/) (Chen, V.B. et al., 2010; Davis, I.W. et al., 2007). Os melhores modelos foram novamente selecionados e submetidos aos 
servidores de refinamento KoBaMIN (http://csb.stanford.edu/kobamin/) (Rodrigues, J.P., Levitt, M. \& Chopra, G., 2012), 3Drefine (http://sysbio.rnet.missouri.edu/3Drefine/) (Bhattacharya, D. \& Cheng, J., 2013), ModRefiner (http://zhanglab.ccmb.med.umich.edu/ModRefiner/) (Xu, D. \& Zhang, Y., 2011) e Yasara (http://www.yasara.org/minimizationserver.htm) (Krieger, E. et al., 2009), e posteriormente reanalisados no QMEAN e Molprobity para constatar se houve melhora com o refinamento. Os melhores modelos refinados foram usados como templates para outra rodada de modelagem no MODELLER, usando diferentes graus de desvios (opção "deviation" do Anexo 1) e diferentes combinações de estruturas. Para resolver os ângulos $\Phi$ e $\Psi$ de aminoácidos ou regiões pontuais antes de rodar a modelagem, foi utilizado o Coot for Windows (Debreczeni, J.E. \& Emsley, P., 2012; Emsley, P. \& Cowtan, K., 2004) ou o Pymol no modo editor (Labby, K.J., 2013). Esse processo foi feito repetidas vezes até a obtenção de uma estrutura tridimensional completa da proteína-alvo que respeitasse as predições de estruturas secundárias e domínios preditas, um gráfico de Ramachandran cotendo $<1 \%$ de ângulos $\Phi$ e $\Psi$ em posição proibida, QMEAN-score > 0,5 e parâmetros geométricos muito próximos dos estabelecidos pelo Molprobity como ideais (amarelos e verdes, ou minimamente vermelhos). Um resumo das etapas de modelagem pode ser visto no fluxograma da Figura 19.

As proteínas modeladas utilizando o método acima foram: BT-R1 (receptor tipo-caderina de Manduca sexta, ordem: Lepidóptera), CadHa (receptor tipo-caderina de Helicoverpa armigera, ordem: Lepidóptera), CadHs23 (caderina de Harpegnathos saltator, ordem: Himenóptera), CadTc23 (receptor tipo-caderina de Tribolium castaneum ordem: Coleóptera) a toxina Cry1 Ab de Bt. As estruturas cristalográficas de Cry1Aa (PDB ID 1CIY) e Cry1Ac (PDB ID 4ARX) foram usadas como referência para a modelagem de Cry1 Ab e as caderinas de Mus musculus (PDB ID 1EDH, 1NCJ, 3LND, 3Q2V, 3Q2W e 3MVS) e de Xenopus laevis (PDB ID 1L3W), acrescidas de heteroátomos de cálcio, foram usadas em diferentes combinações durante a primeira modelagem das caderinas citadas acima (Anexo 1 da seção I). As caderinas são proteínas de membrana e portanto podem ser divididas em quatro regiões: uma porção N-terminal extracelular (ECs ou CRs), um domínio próximo a membrana (MPED), uma região transmembrana (TM) e uma região citosólica C-terminal (CYTO) (Figura 18). 


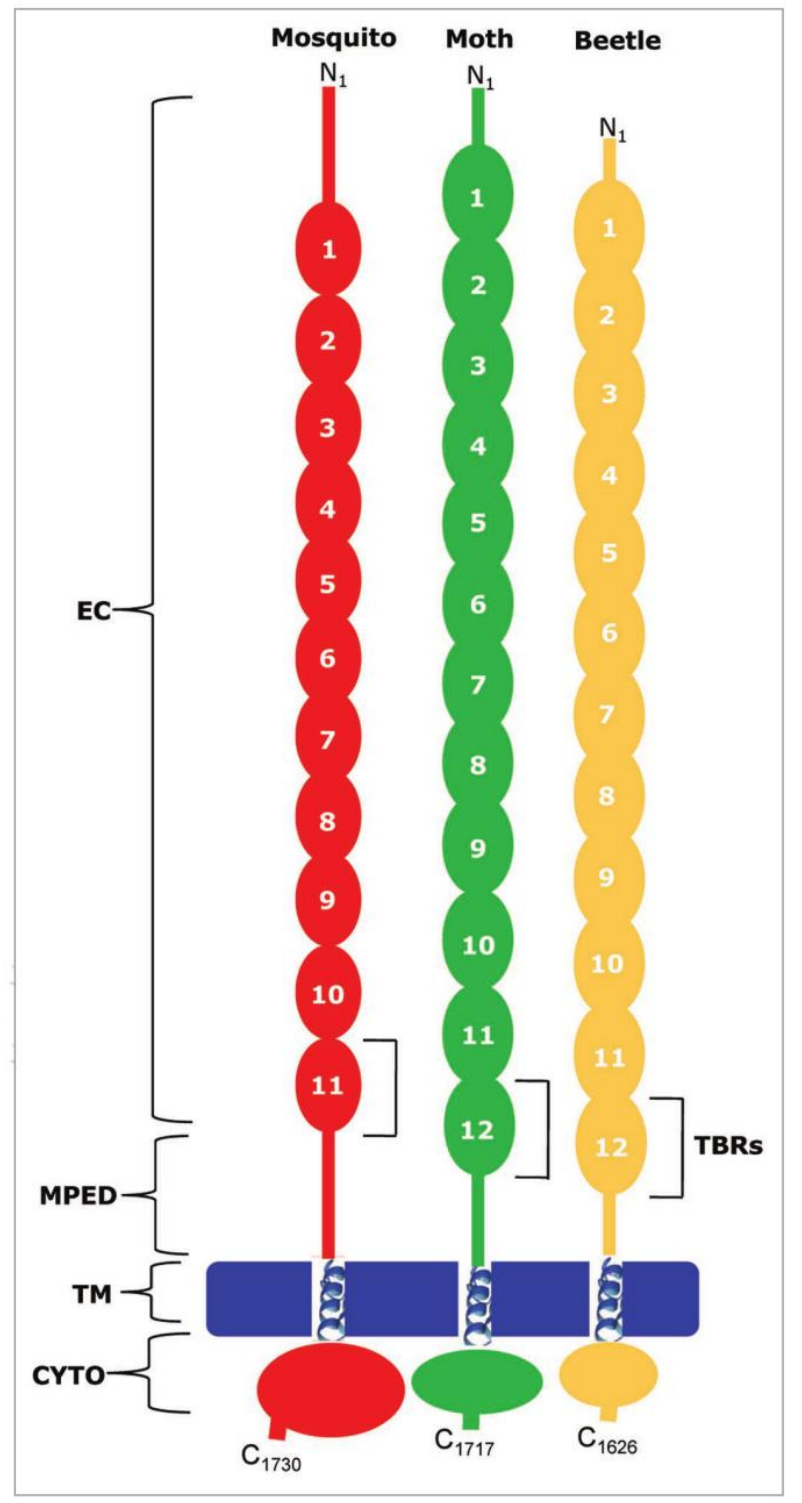

(Ibrahim, M.A. et al., 2010)

Figura 18: Ilustração da estrutura de caderinas. A região putativa de ligação às toxinas Cry (TBRs) são mostradas para uma caderina de díptera (vermelho), lepidóptera (verde) e coleóptera (amarelo).

No caso das caderinas que atuam como receptores para toxinas 3D-Cry, apenas a região extracelular entra em contato com a toxina. Portanto, apenas os últimos cinco CRs (CR8-CR12) foram modelados para reproduzir a interação das toxinas 3D-Cry, já que neles estão contidas as regiões preditas como de ligação às toxinas (TBRs) (Dorsch, J.A. et al., 2002; Hua, G., Jurat-Fuentes, J.L. \& Adang, M.J., 2004). A toxina Cry1 Ab foi modelada apenas para seu fragmento ativo. As informações sobre as sequências modeladas estão na Tabela 5. 


\begin{tabular}{|ccc|}
\hline Modelo & Acesso & Região \\
\hline Cry1Ab & AEV45790.1 & $33-610$ \\
BT-R1 & AAG37912.1 & $882-1450$ \\
CadHa & ACZ06065.1 & $889-1457$ \\
CadTc23 & EEZ99177.1 & $1014-1572$ \\
CadHs23 & EFN81180.1 & $1060-1610$ \\
\hline
\end{tabular}

Tabela 5: Número de acesso e região das sequências modeladas.

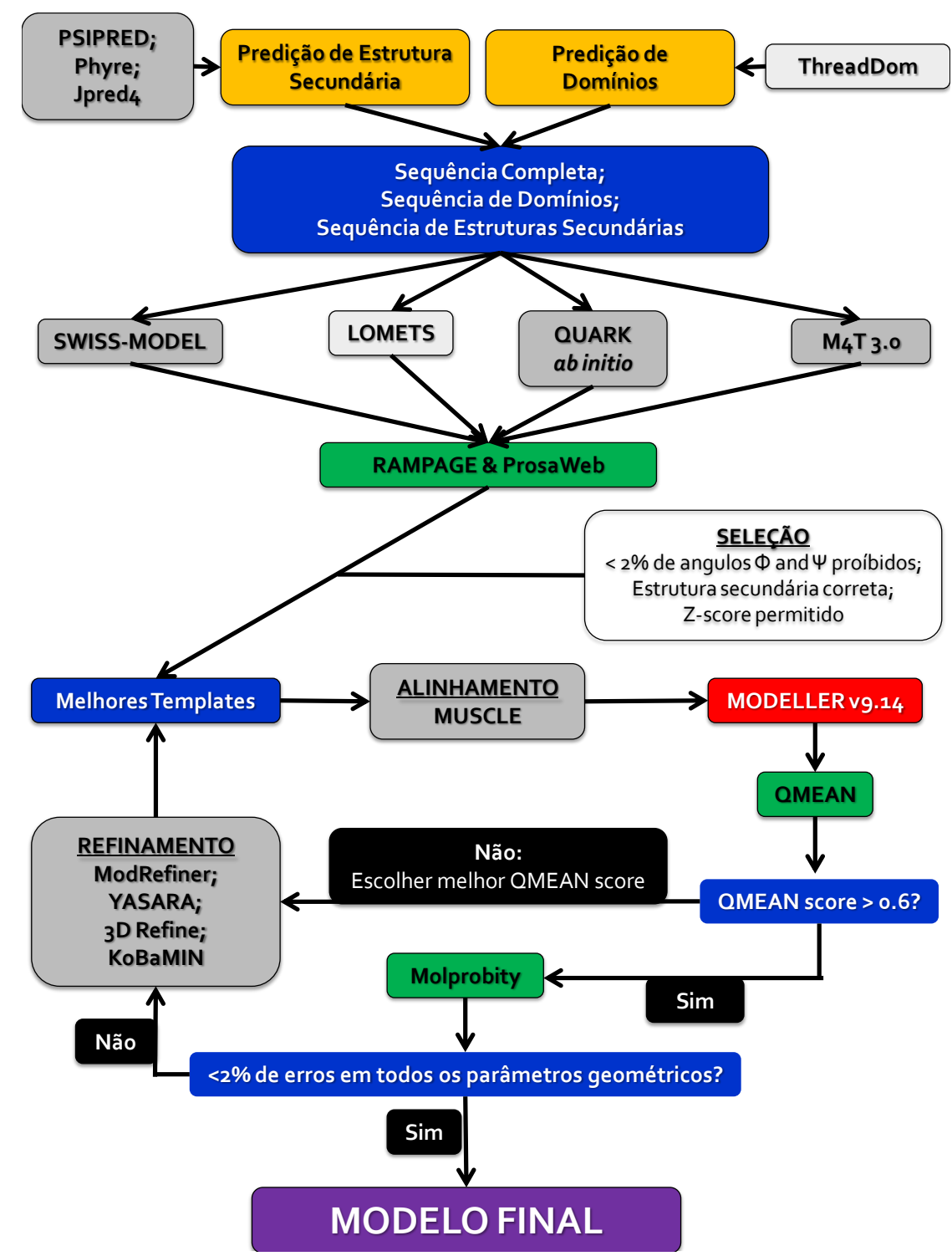

Figura 19: Fluxograma do método de modelagem por homologia. 


\subsubsection{Gerando modelos de interação}

Os dockings foram realizados no servidor ClusPro 2.0 (http://cluspro.bu.edu/) usando as opções padrões, sem qualquer restrição ou direcionamento entre moléculas (Comeau, S.R. et al., 2004a, 2004b; Kozakov, D. et al., 2006). As caderinas foram submetidas ao docking com e sem íons de $\mathrm{Ca}^{2+}$ posicionados entre seus domínios extracelulares (CRs).

O ClusPro faz uma avaliação de energia livre empírica que permite que o resultado do algoritmo de correlação de Fourier seja rapidamente filtrado usando uma combinação de energia de dessolvatação e energia eletrostática (calculadas usando um potencial de Coulomb). Essa abordagem resulta em algumas estruturas próximas às nativas passando pelo filtro, enquanto elimina muito dos falsos positivos. $\mathrm{O}$ passo seguinte tira vantagem do fato de que a paisagem de energia livre (Figura 20) exibe seu mais amplo e profundo poço (poço à direita) perto da estrutura nativa, inferido como o mínimo global, com vários mínimos locais espalhados pela paisagem de energia, que são poços mais estreitos e rasos que o mínimo global (poços à esquerda), (Comeau, S.R. et al., 2004a).

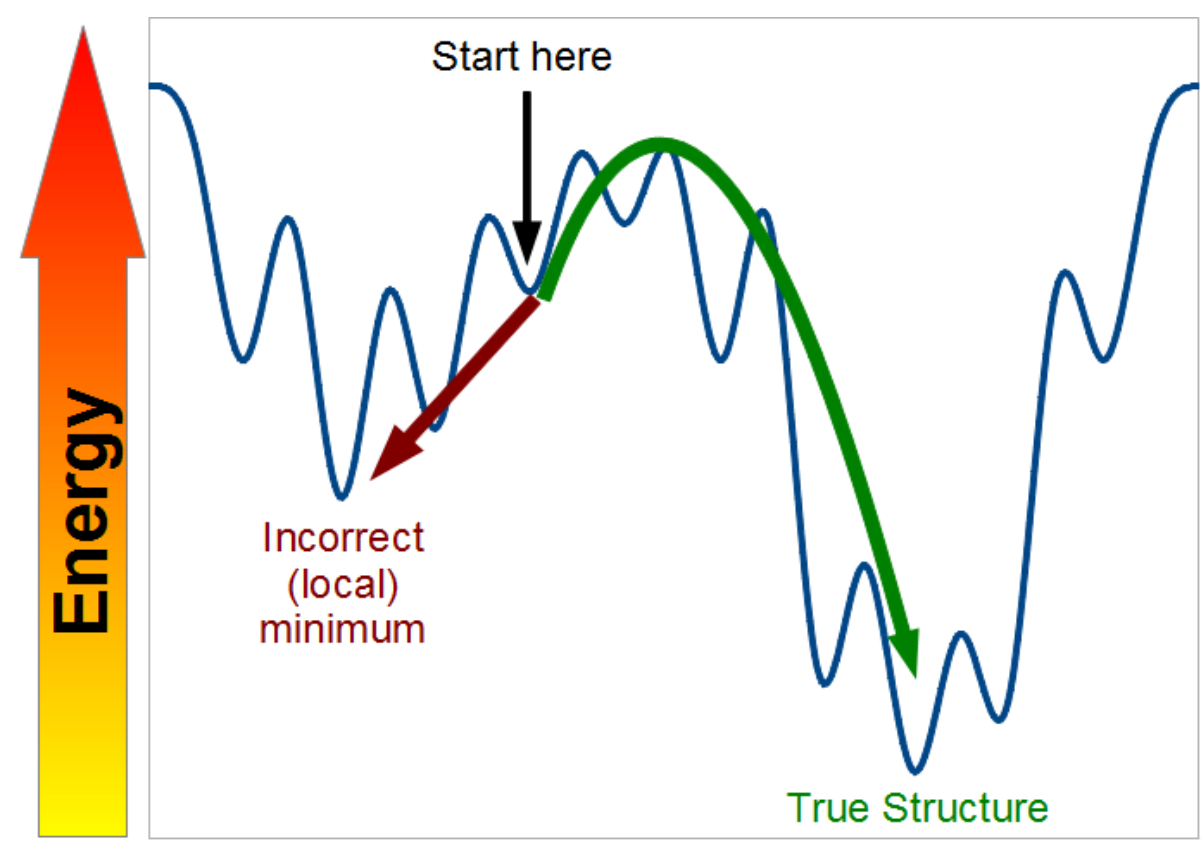

Figura 20: Representação de uma paisagem de energia livre. A seta verde indicia o poço com menor energia livre na paisagem, ou mínimo global. A seta vermelha indica um poço de mínimo local. Próximo ao mínimo global em uma paisagem de energia livre existem muitos mínimos locais, de maneira que eles podem ser facilmente agrupados. 
Assim, para melhor discriminar (i.e. eliminar falso positivos), as estruturas putativas são agrupadas com o grupo mais populoso ao centro, e assume-se que este grupo possui estruturas com uma interface de ligação mais próxima à nativa (Camacho, C.J. et al., 1999). Esse método é remanescente do trabalho de Shortle et al. para a predição de estrutura de proteínas, onde a conformação nativa foi vista como àquela com maior número de vizinhos estruturais, ou seja, o grupo contendo o maior número de estruturas com mínimos locais é geralmente o grupo que contém a estrutura nativa ao centro (Shortle, D., Simons, K.T. \& Baker, D., 1998).

O servidor de docking ClusPro participa do CAPRI (Avaliação Crítica da Predição de Interações) (Janin, J. et al., 2003) desde 2004. Para cada alvo testado durante o CAPRI, os servidores devem submeter modelos em $48 \mathrm{~h}$. O ClusPro realiza três passos computacionais: (1) docking rígido usando transformada rápida de Fourier (FFT); (2) Um agrupamento das estruturas geradas baseado no RMSD (Root Mean Square Deviation; quantificação da deformação média da estrutura em comparação à referencia do ponto inicial); (3) refinamento das estruturas relacionadas (Kozakov, D. et al., 2013). Os resultados do CAPRI 2013 mostram que o servidor gera de forma confiável modelos aceitáveis ou de precisão média para alvos de dificuldade moderada. A qualidade dos dockings automáticos realizados pelo ClusPro é muito próxima à dos melhores grupos humanos de pesquisa em predição, incluindo os próprios inventores do servidor. Apenas duas das seis tentativas manuais de refinamento usando minimização de Monte Carlo apresentou melhora significativa na precisão dos complexos gerados pelo ClusPro. Por fim, o melhor modelo ranqueado pelo Cluspro foi aceitável ou de qualidade superior para todos os seis alvos testados nessa rodada do CAPRI. Além disso, o melhor modelo ranqueado também foi o de mais alta qualidade para cinco dentre os seis alvos, confirmando que o ranqueamento dos modelos baseado no tamanho de agrupamentos pode confiavelmente identificar as melhores conformações próximas à nativa (Kozakov, D. et al., 2013).

Com base nas informações acima, foram submetidas para docking no ClusPro estruturas obtidas por Modelagem por Homologia $(\mathrm{MpH})$ e de Cristalografia de Raios-X (CRX). As combinações de receptor x ligante foram : 


\section{BT-R $(\mathrm{MpH})$ x Cry1 Aa $(\mathrm{CRX})$ \\ 2. BT-R $1(\mathrm{MpH}) \times \operatorname{Cry} 1 \mathrm{Ab}(\mathrm{MpH})$ \\ 3. BT-R $(\mathrm{MpH})$ x Cry1 Ac $(\mathrm{CRX})$}

O ClusPro ranqueou 120 modelos para cada uma das combinações, baseando-se em potencial eletrostático e forças de Van der Waals (VdW). A totalidade de 720 modelos (360 com e 360 sem íons de $\mathrm{Ca}^{2+}$ ) foram analisados no programa Pymol (DeLano, W.L., 2004, 2009; DeLano, W.L. \& Lam, J.W., 2005) e filtrados de acordo com dados experimentais relatados na literatura (Abdul-Rauf, M. \& Ellar, D.J., 1999; Chen, J. et al., 2007; Chen, X.J. et al., 1995; Rajamohan, F. et al., 1995; Rajamohan, F., Alzate, O., et al., 1996; Rajamohan, F., Hussain, S.R., et al., 1996; Xie, R. et al., 2005). Dois modelos distintos satisfizeram as condições do filtro para a interação entre o receptor e ligante.

\subsection{Resultados e Discussão}

Todas as caderinas utilizadas nesse trabalho foram modeladas com íons de cálcio ligados às regiões entre as $\mathrm{CRs}$, conforme descrito por Sotomayor e Schulten (Sotomayor, M. \& Schulten, K., 2008). O motivo disso é que na ausência de íons de cálcio as CRs tem uma estrutura flexível e variável. Outro fator é que a estrutura rígida da caderina tem uma superfície maior para interagir com toxinas Cry, uma vez que menos áreas de contato estão disponíveis em uma caderina dobrada. A qualidade dos modelos de BT-R1 e Cry1Ab está apresentada na Figura 21.

$\mathrm{O}$ docking, no entanto, foi realizado com ou sem a presença de $\mathrm{Ca}^{2+}$ ligados à caderina, afim de avaliar a influência destes na interação com a toxina. Como as caderinas modeladas possuem cinco CRs que formam uma proteína filamentosa, existe uma extremidade $\mathrm{N}$ - e C-terminal bem definida (Figura 18). A região que se liga às toxinas 3D-Cry, conforme descrito na literatura, é equivalente à extremidade C-terminal nas caderinas modeladas (Dorsch, J.A. et al., 2002; Hua, G., Jurat-Fuentes, J.L. \& Adang, M.J., 2004). A primeira filtragem dos complexos gerados pelo ClusPro foi feita selecionando os modelos que estavam interagindo na extremidade terminal. Notavelmente, o docking realizado com íons $\mathrm{Ca}^{2+}$ gerou mais complexos interagindo na extremidade C-terminal do que o docking realizado na ausência deste íon. A segunda filtragem foi com base nos relatos da literatura (seção 2.2.2.). Dessa forma, foram 
selecionados modelos contendo os loops $\alpha 8,2$ e 3, do D-II, e a região $\beta 15-\beta 16$, do D-III (Ibrahim, M.A. et al., 2010), na interface de interação com a caderina.
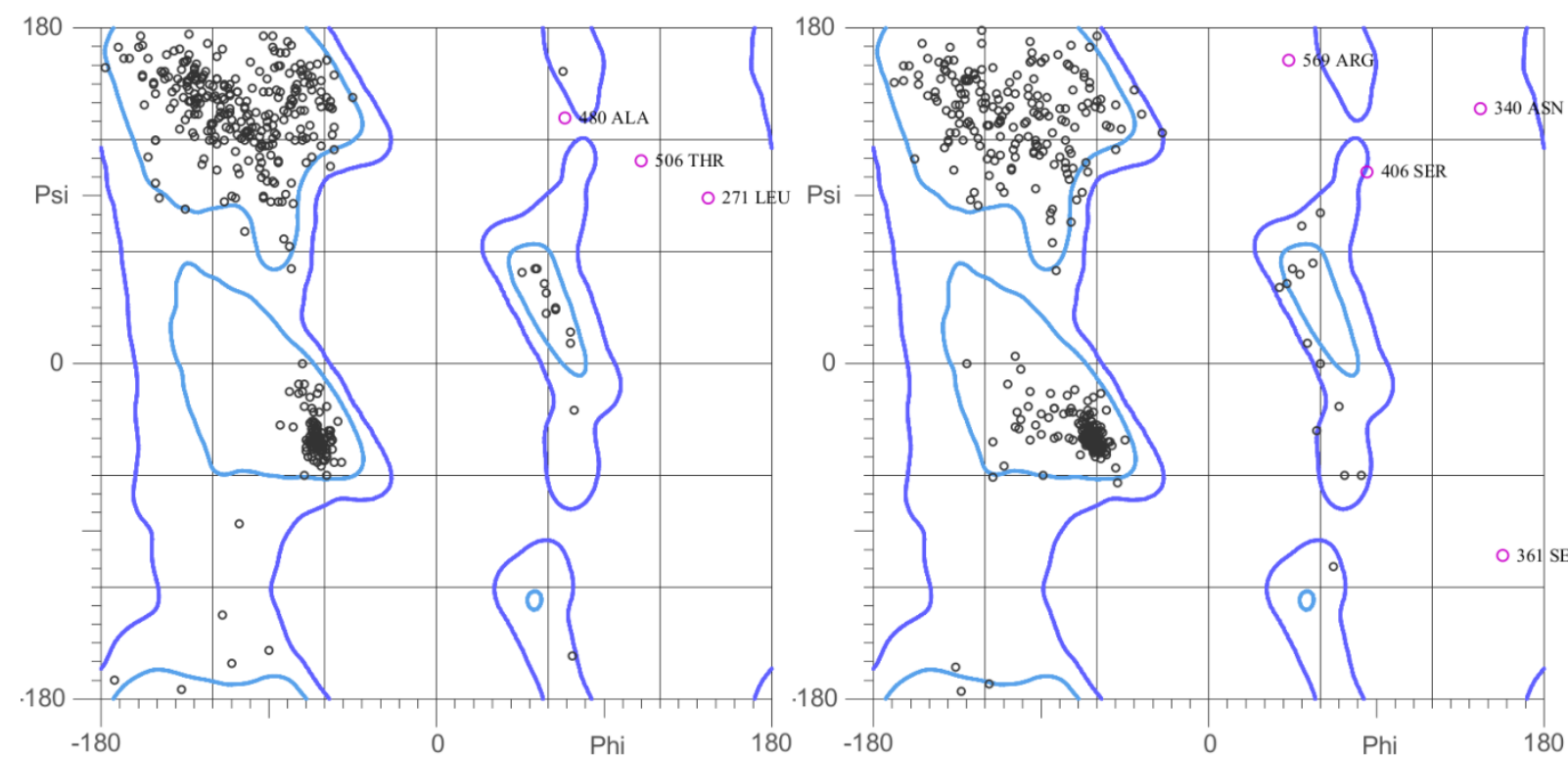

Figura 21: Gráfico de Ramachandran pra BT-R (esquerda) e Cry1Ab (direita). Pontos legendados são resíduos com ângulos $\Phi$ e $\Psi$ proibidos. O modelo de BT- $\mathrm{R}_{1}$ atingiu $97 \%$ de regiões favoráveis e o de Cry1 Ab, $98 \%$.

Após a segunda filtragem, dois modelos, doravante denominados Dock1 e Dock2, satisfizeram o filtro de seleção. O modelo Dock2 foi obtido apenas em complexos formados por Cry1 Ab e BT- $\mathrm{R}_{1}$ ligado a $\mathrm{Ca}^{2+}$, enquanto Dock1 foi obtido em todas as tentativas de dockings e apresenta várias poses equivalentes em toda a população de complexos coletados. Considerando os complexos formados por Cry1 Ab, as regiões que participam da interface de interação em ambos modelos são as mesmas, com duas exceções: a participação do loop 2 (D-II) de Cry1Ab na interface é exclusiva do Dock1 e a participação da região ${ }_{1421} \mathrm{QTGVLTLNFQ}_{1431}$ (CR12) de BT-R 1 é exclusiva do Dock2. Esta última região foi descrita em alguns trabalhos como sendo importante para a ligação da caderina às toxinas de Bt (Gomez, I. et al., 2006; Peng, D., Xu, X., Ruan, L., et al., 2010; Peng, D., Xu, X., Ye, W., et al., 2010; Xie, R. et al., 2005).

Xie et al. (2005) descreveram a região ${ }_{1421}$ QTGVLTLNFQ $_{1431}$, da caderina de Heliothis virescens, como a região de ligação ao loop 3 (D-II) de Cry1 Ac, e foram além afirmando que os resíduos L1425 e F1429 são essenciais para a interação entre esses epitopos. Gomez et al. (2006), por sua vez, sequenciaram a região CDR1-L de um 
anticorpo específico para o loop 3 de Cry1 Ab e descobriam tratar-se do epitopo QASQSIVS. Por homologia e similaridade hidropática, eles associaram esse epitopo com a região ${ }_{1412} \mathrm{NAQTGVLT}_{1419}$ do receptor $\mathrm{BT}_{-\mathrm{R}_{1}}$ e com a região ${ }_{1421}$ QTGVLTLNFQ $_{1431}$ da caderina de Heliothis virescens, corroborando com os dados obtidos por Xie et al. (2005).

"Hidropaticidade" é a energia livre da transferência de um aminoácido do ambiente hidrofóbico para o ambiente aquoso (assumindo constante dielétrica 2), medida em $\mathrm{kcal} / \mathrm{mol}$. Neste trabalho foi verificado novamente a similaridade hidropática das regiões citadas acima usando a ferramenta AlignMe (http://www.bioinfo.mpg.de/AlignMe/) (Stamm, M. et al., 2014) e foi atestada a afirmação dos autores. No entanto, os cálculos usualmente empregados para verificar similaridade hidropática (Anexo 3 da Seção I) não levam em conta que as sequências de aminoácidos podem ser lidas ao contrário, o que pode acarretar em falso-negativos se a busca por similaridade for feita apenas no sentido C-terminal. Esse fator tem que ser levado em conta principalmente em tratando-se de regiões de interação, pois estas possuem caráter tridimensional e não obedecem o sentido o qual humanos escrevem. Infelizmente, muitos trabalhos não tomam esse cuidado e acabam deixando lacunas que ainda necessitam ser preenchidas. Com base nessas informações, a sequência de BT- $\mathrm{R}_{1}$ que foi modelada neste trabalho (Tabela 5) foi invertida (http://textmechanic.com/Reverse-Text-Generator.html) e submetida à ferramenta AlignMe junto com o epitopo QASQSIVS. Não surpreendentemente, o epitopo alinhou na região específica GASKEIFA, correspondente ao fragmento ${ }_{1251} \mathrm{AFIEKSAG}_{1258}$ de BT- $R_{1}$. O interessante é que essa é justamente a região da interface em que o loop 3 (DII) está ligado no modelo Dock1. Uma comparação entre a similaridade hidropática das regiões QASQSIVS/1258 GASKEIFA ${ }_{1251}$ e QASQSIVS/1412NAQTGVLT 1419 pode ser vista na Figura 22.

A consequência dessas duas discrepâncias é que em Dock1 a toxina Cry1Ab parece estar ligada aos domínios CR11 e CR12 de BT-R ${ }_{1}$, enquanto em Dock2 a toxina parece estar principalmente ligada a CR12. Já foi descrito na literatura que a expressão de CR12 é suficiente para a ligação às toxinas Cry1A em ensaios de dot-blot (Hua, G., Jurat-Fuentes, J.L. \& Adang, M.J., 2004), não havendo necessidade de CR11 para a ligação. No entanto, o mesmo trabalho mostra que a ligação do fragmento contendo CR11-CR12 é muito mais eficiente comparado à ligação usando apenas CR12, o que 
corrobora com Dorsch et al. (2002), onde CR11 e CR12 foram delimitados como a região de ligação.
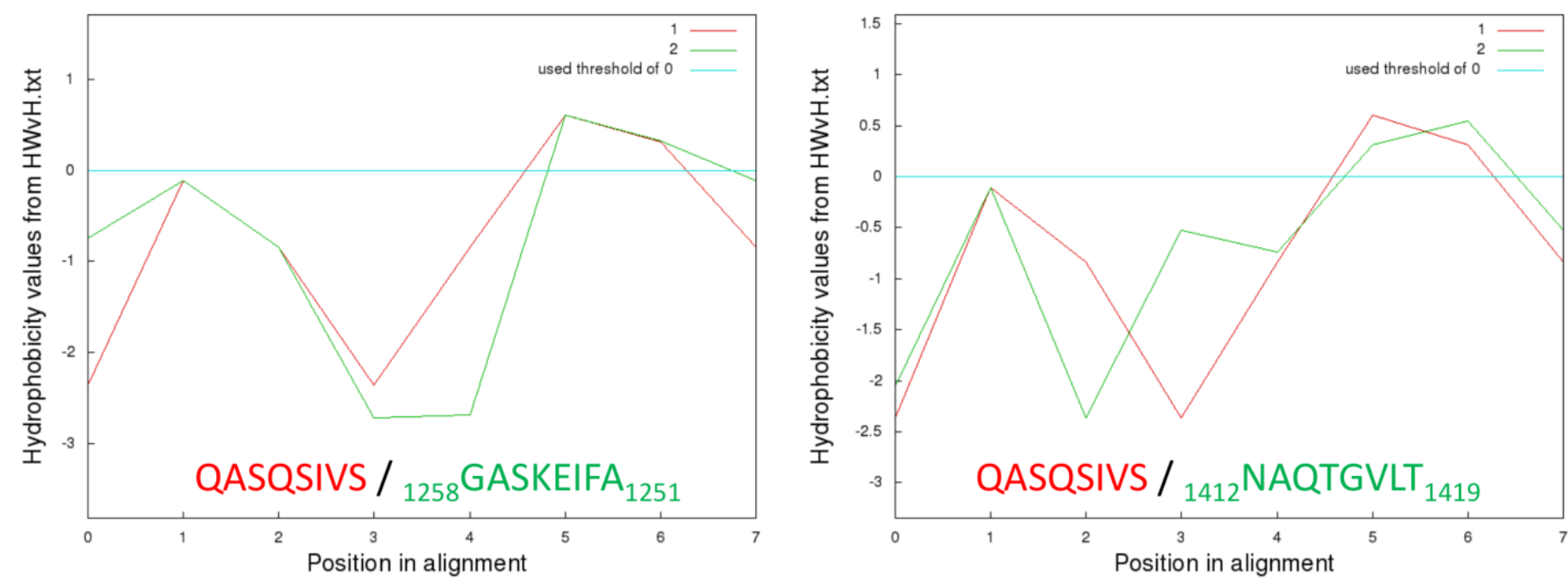

Figura 22: Comparação do perfil de hidropaticidade entre fragmentos de $B T-R_{1}$ e opitopo de um anticorpo específico para o Loop 3 de Cry1Ab. Pontos acima de zero no eixo Y são considerados hidrofóbicos. Gráficos e alinhamentos foram gerados usando a ferramenta AlignMe (Stamm, M. et al., 2014) usando a opção "fast align" com janela de 3 aminoácidos. A sequência do epitopo foi descrito por Gomez et. al (2006). A região ${ }_{1258}$ GASKEIFA $_{1251}$ participa da interface de interação nos modelos de Dock1 e a região ${ }_{1412} \mathrm{NAQTGVLT}_{1419}$ participa da interface de interação no modelo Dock2.

Uma peculiaridade do trabalho realizado por Hua et al. (2004) é que todos os fragmentos truncados de $\mathrm{BT}-\mathrm{R}_{1}$ que se ligaram às toxinas da família Cry1A expressavam também o domínio extracelular próximo à membrana (MPED). Como os autores não testaram a capacidade desse domínio de se ligar singularmente em toxinas Cry1A, não é claro sua participação para a ligação dos fragmentos CR11 e/ou CR12 às toxinas. No entanto, resultados não publicados por Hua et al. (obtido por uma troca de email, Anexo 2 da Seção I) concluem que o MPED não participa da ligação com toxinas Cry1A. O ponto levantado pelo Prof. Dr. Adang (Anexo 2) foi esclarecido em uma outra troca de email e corroborou com a afirmação feita pelo Dr. Hua. A Figura 23 ilustra o modelo Dock2 obtido a partir dos complexos de docking com Cry1 Ab e os modelos de Dock1 obtidos a partir dos complexos com todas as toxinas da família Cry1A. 


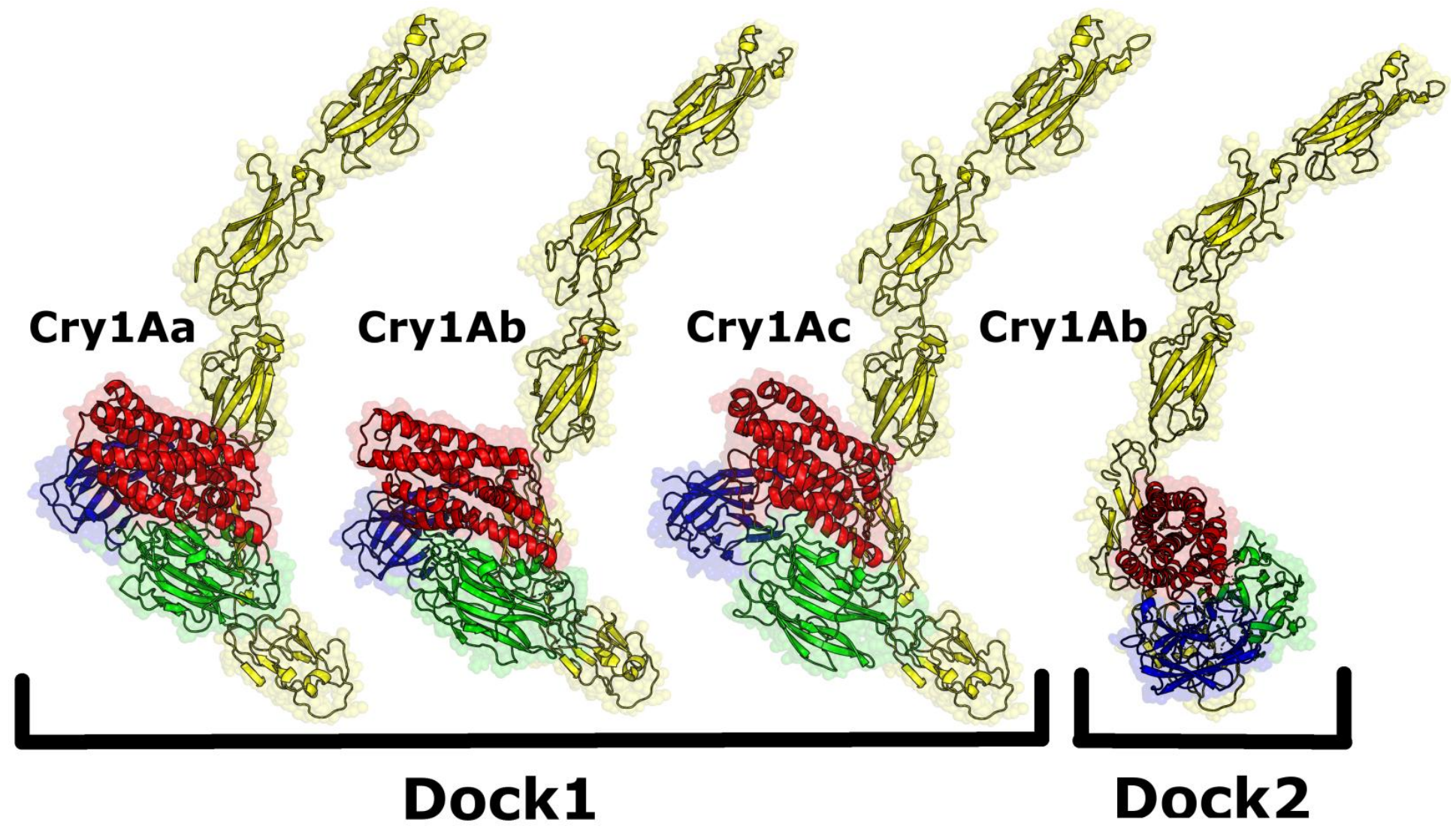

Figura 23: Docking molecular das toxinas Cry1Aa, Cry1Ab e Cry1Ac com o receptor tipo-caderina BT-R $\mathbf{R}_{1}$ Os ectodomínios repetidos do receptor BT- $\mathrm{R}_{1}$ encontram-se em amarelo e os domínios I, II e III das toxinas Cry1 A encontram-se em vermelho, verde e azul, respectivamente.

\subsection{Conclusão}

Os complexos de docking formados por Cry1 Ab e BT-R 1 permitiram a obtenção de dois modelos distintos que satisfizeram as regiões de ligação descritas na literatura. Ambos modelos, Dock1 e Dock2, apresentam uma região exclusiva em suas interfaces de interação. O loop 2 (D-II) participa da ligação ao receptor BT-R ${ }_{1}$ no complexo formado por Dock1 e a região ${ }_{1421} \mathrm{QTGVLTLNFQ}_{1431}$ (CR12) está presente na interface de ligação formada em Dock2. A toxina Cry1 Ab se liga em CR11 e CR12 no modelo Dock1, enquanto em Dock2 esta se liga principalmente ao domínio CR12. Embora os dois modelos tenham respaldo da literatura (Ibrahim, M.A. et al., 2010), o modelo Dock1 teve maior representação e reprodutibilidade na população de complexos gerados pelo servidor ClusPro. De acordo com a metodologia usada pelo ClusPro, esse é o principal indício para que uma estrutura esteja correta. No entanto, levando em consideração a presença da região ${ }_{1421} Q_{\text {TGVLTLNFQ }}{ }_{1431}$ (Gomez, I. et al., 2006) na 
interface de interação de Dock2, ambos modelos, complexados a Cry1 Ab, foram selecionados para análise posterior usando dinâmica molecular.

A existência inicial de dois modelos distintos que corroboram com a literatura pode ser vista, à primeira vista, como contraditória. Mas mesmo que um dos modelos esteja completamente errado, a existência de duas formas distintas permite gerar comparações e, principalmente, achar características ou informações comuns aos dois. Essas informações podem ser igualmente importantes à obtenção de um modelo, como a aparente conservação de hidropaticidade na interface de interação do loop 3, seja ela qual for. 


\section{Capítulo 3}

\section{Dinâmica Molecular}

"Scientific results are beautiful. Thus, science is the beauty salon for the thorough observations."

- Conclusão lógica a qual cheguei durante uma das madrugadas que passei escrevendo este documento no laboratório. 


\subsection{Conceito}

\subsubsection{Dinâmica molecular}

As simulações de dinâmica molecular clássica utilizam as equações de movimento de Newton para calcular a trajetória de partículas a partir de uma configuração inicial. Para cada partícula no sistema, a força total atuando sobre ela é calculada a partir das interações com outras partículas e, portanto, podem ser descritas por um campo de forças. A segunda lei de Newton nos fala que a força atuando sobre uma partícula é equivalente à massa daquela partícula vezes a aceleração à qual ela se encontra submetida, ou seja, $F=m a$. Essa equação pode ser reescrita como:

$$
\frac{d^{2} x_{i}}{d t^{2}}=\frac{F_{x_{i}}}{m_{i}}
$$

onde $x$ é a distância, $t$ o tempo e $d^{2} x / d t^{2}$ é a aceleração da partícula $i$ (a primeira derivada da função $x / t$ é igual a velocidade instantânea, e a derivação dessa velocidade é igual a aceleração). Portanto, a força dividida pela massa de uma partícula nos dá a sua aceleração, o que, junto com sua posição anterior e sua velocidade, determina qual será sua nova posição após um pequeno intervalo de tempo. A alta resolução espacial e temporal faz das simulações de dinâmica molecular uma ferramenta útil para testar modelos baseados em dados experimentais, para compreender princípios que norteiam uma determinada função e para formular novas hipóteses. Infelizmente, o tamanho dos sistemas que podem ser simulados é limitado, bem como a escala de tempo.

Já entendemos como calcular a trajetória de uma partícula, mas para isso precisaremos saber calcular as forças atuando sobre ela. Dado que as partículas são átomos, as forças atuando sobre eles são oriundas das interações com o sistema. Portanto, precisamos descrever o movimento dos átomos através de suas interações em um sistema, e para isso são aplicados conceitos de mecânica quântica. No entanto, as propriedades macroscópicas que podem ser medidas em um experimento de dinâmica molecular usando-se da mecânica quântica não são observações diretas, mas sim as médias sobre bilhões de átomos que representam um conjunto ao qual damos nome de estado. Logo, fica claro que o estado que representa as propriedades macroscópicas dos átomos precisa ter significância estatística, pois nosso objeto de estudo pode ocupar uma vasta população de estados. Aqui, o uso da mecânica estatística se torna necessário 
se quisermos tirar alguma informação desse conjunto de estados. O que ela faz é calcular a probabilidade de todos os estados em que seu sistema pode se encontrar. Assume-se, então, que o estado de maior probabilidade é o estado correto para o fenômeno que você está observando.

Em mecânica quântica, o estado fundamental de um sistema é definido pela Equação de Schroedinger, uma função matemática (simbolizada pela letra grega psi maiúscula: $\Psi$ ) chamada de função de estado ou função de onda dependente do tempo (Figura 24). Essa função consegue nos dizer como acontece a interação entre átomos, uma vez que a interação destes é feita através dos elétrons e a resolução da equação descreve completamente as posições eletrônicas em uma molécula.

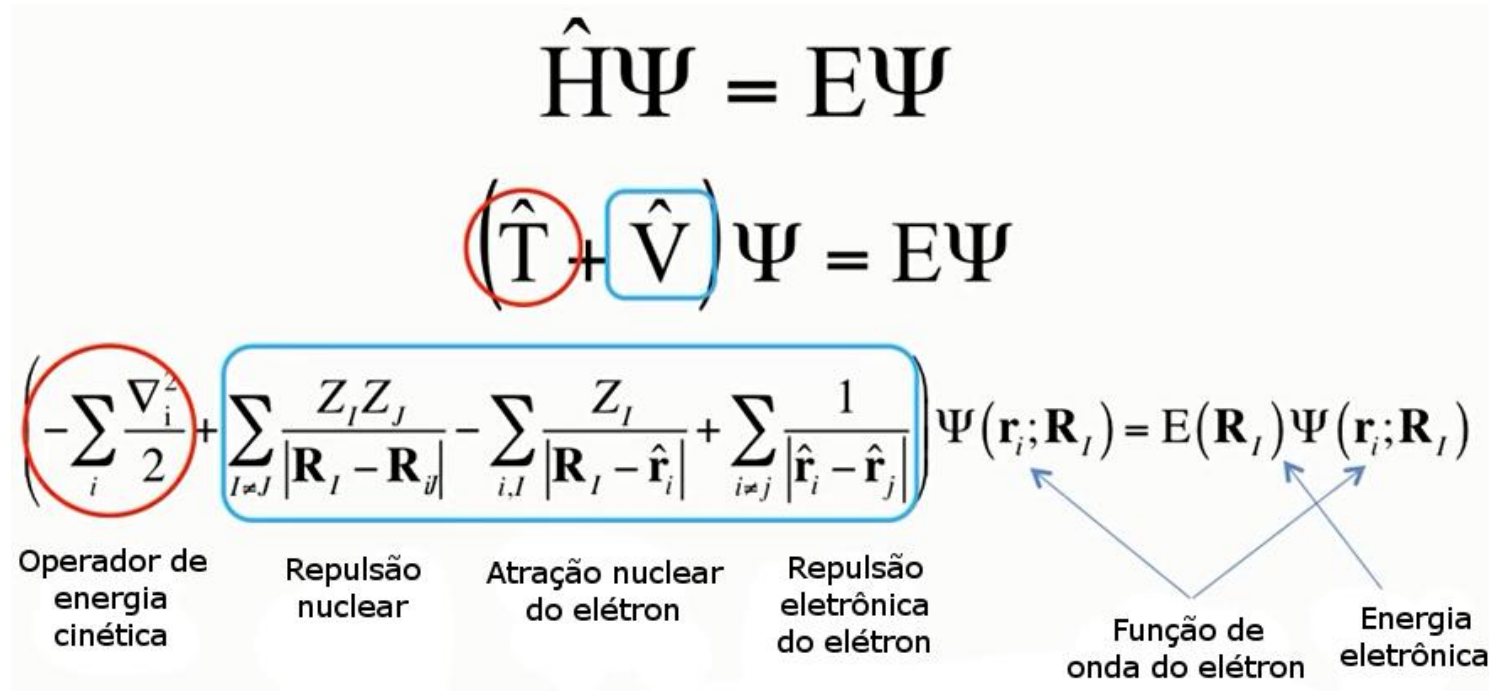

Figura 24: Função de estado $\Psi$. H é o operador Hamiltoniano e corresponde à energia total do sistema. Sua decomposição gera os termos de energia cinética e energia atômica. Um operador matemático seleciona uma função e a retorna multiplicada por um número, que neste caso é a energia. A função de onda $\Psi$ depende do tempo e contém as coordenadas dos elétrons. A resolução dessa função permite saber onde os elétrons estão em uma molécula.

Usando essa função, os movimentos dos elétrons podem ser tratados como ondas e os estados estacionários em um átomo, como ondas estacionárias. Ou seja, a equação de ondas que descreve o movimento de um elétron preso dentro de um átomo ou molécula deve ser análoga à que se usa para descrever um sistema de ondas estacionárias. Ondas estacionárias são ondas que possuem um padrão de vibração estacionário. Formam-se a partir de uma superposição de duas ondas idênticas, mas em sentidos opostos, normalmente quando as ondas estão confinadas no espaço, como as 
ondas de uma corda com as extremidades fixas. Esse tipo de onda é caracterizado por pontos fixos de valor zero, chamados de nodos, e pontos de máximo e mínimo também fixo, chamados de antinodos. Esse tratamento implica que a energia potencial do sistema é uma função das posições atômicas, pois assume-se que os elétrons estão sempre em seu estado fundamental e isso fornece uma superfície potencial para que os átomos se movam.

Idealmente, a equação de Schroedinger deve ser capaz de prever todas as propriedades de qualquer molécula com uma precisão inicial arbitrária (Lindahl, E., 2008). No entanto, assim que algumas poucas partículas estão envolvidas, cria-se uma limitação computacional que torna inviável resolver sistemas muito grandes e torna-se necessário introduzir aproximações. Por exemplo, a densidade eletrônica de um elétron contém todas as informações contidas na função de onda da equação de Schroedinger e torna possível a aproximação do resultado dessa equação com menos cálculos. Outro caso é a utilização de parametrizações empíricas de modelos (obtidas experimentalmente), como o uso de cargas pontuais singulares para descrever as interações elétricas, ao invés de uma descrição quântica dos elétrons (Lindahl, E., 2008). Em dinâmica clássica, as funções empíricas usadas para a aproximação da equação de Schroedinger são chamadas campos de força, e permitem calcular as interações e avaliar a energia potencial do sistema em função de coordenadas atômicas pontuais (MacKerell, A.D. et al., 1998).

Um campo de força consiste tanto no conjunto de equações usadas para calcular a energia potencial e as forças a partir de coordenadas atômicas, quanto na coleção de parâmetros usados nessas equações. Para a maioria dos casos, essas aproximações funcionam bem, mas não permitem reproduzir efeitos quânticos como a formação e quebra de ligações. Todos os campos de força comuns subdividem as funções de potencial em duas classes. As interações de ligação covalente compreendem às energias de estiramento, de curvatura de ângulo, de potencial de torção ao rotacionar ligações e ângulo diedral impróprio, que são ângulos normalmente fixos durante a simulação (Figura 25). O restante das interações não covalentes consiste na repulsão de LennardJones (LJ) e dispersões de London, e nas interações eletrostáticas de Coulomb (Coul). Essas são tipicamente computadas a partir de listas de átomos vizinhos a cada 5 a 10 passos de 0,002 picosegundos da dinâmica. Dado o potencial (Figura 25) e a força (ou 
gradiente negativo de potencial) para todos os átomos, as coordenadas são atualizadas a cada passo.

$$
\begin{gathered}
V_{\text {total }}=V_{\text {covalente }}+V_{\text {não-covalente }} \\
V_{\text {total }}=V_{\text {ligação }}+V_{\text {ângulo }}+V_{\text {diedro }}+V_{\text {eletro }}+V_{L J}
\end{gathered}
$$

Estiramento de ligaçäo covalente

$$
V_{\text {ligạão }}=\sum_{\text {ligậ̣ose }} \frac{1}{2} k_{b}\left(b-b_{0}\right)^{2}
$$

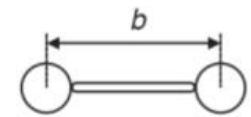

Energia de ângulo covalente

$$
V_{\text {ângulo }}=\sum_{\text {ângulos }} \frac{1}{2} k_{\theta}\left(\theta-\theta_{0}\right)^{2}
$$

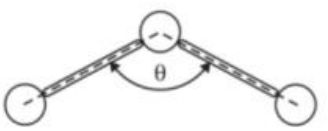

\section{Energia de ângulo diedral covalente}

$$
V_{\text {diedro }}=\sum_{\text {diedrais }} \frac{1}{2} k_{\phi}[1+\cos (n \phi-\delta)]^{2}
$$
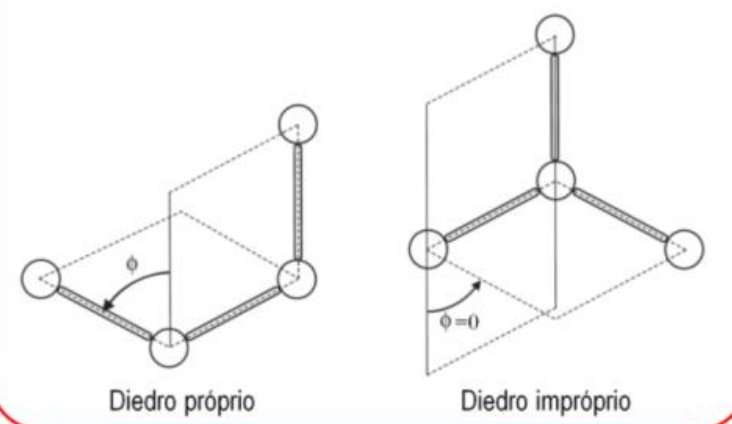

Figura 25: Exemplos de funções de interação em campos de força modernos. A energia potencial $V_{\text {total }}$ é calculada a partir das energias individuais correspondendo às interações covalentes de não covalentes. Energia potencial é a força necessária para trazer uma partícula do infinito até um ponto de referência. Fonte: (Sachett, L., 2014)
Energia eletrostática

$$
V_{\text {eletro }}=\frac{1}{4 \pi \varepsilon_{0} \varepsilon} \sum_{\text {pares ij }} \frac{q_{i} q_{j}}{r_{i j}^{2}}
$$

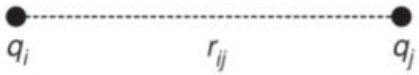

\section{Potencial de Lennard-Jones}

$$
V_{\mathrm{LJ}}=\sum_{\text {pares ij }} 4 \varepsilon_{i j}\left\{\left(\frac{\sigma_{i j}}{r_{i j}}\right)^{12}-\left(\frac{\sigma_{i j}}{r_{i j}}\right)^{6}\right\}
$$

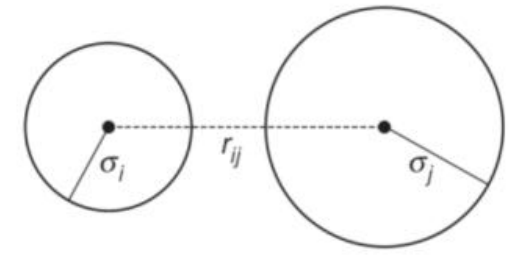


Para minimização de energia, o algoritmo de gradiente descendente simplesmente move cada átomo uma curta distância na direção da energia decrescente. Já a dinâmica molecular é realizada por meio da integração das equações de movimento de Newton em função do tempo:

$$
\mathbf{F}_{\mathrm{i}}=\frac{-\partial \mathrm{V}\left(\mathbf{r}_{1} \ldots, \mathbf{r}_{\mathrm{N}}\right)}{\partial \mathbf{r}_{\mathrm{i}}} \quad m_{i} \cdot \underline{\partial^{2} \mathbf{r}_{\mathrm{i}}}=\mathbf{F}_{\mathrm{i}}
$$

As coordenadas atualizadas são então usadas para avaliar a energia potencial novamente e recalcular o novo passo, conforme o fluxograma da Figura 26.

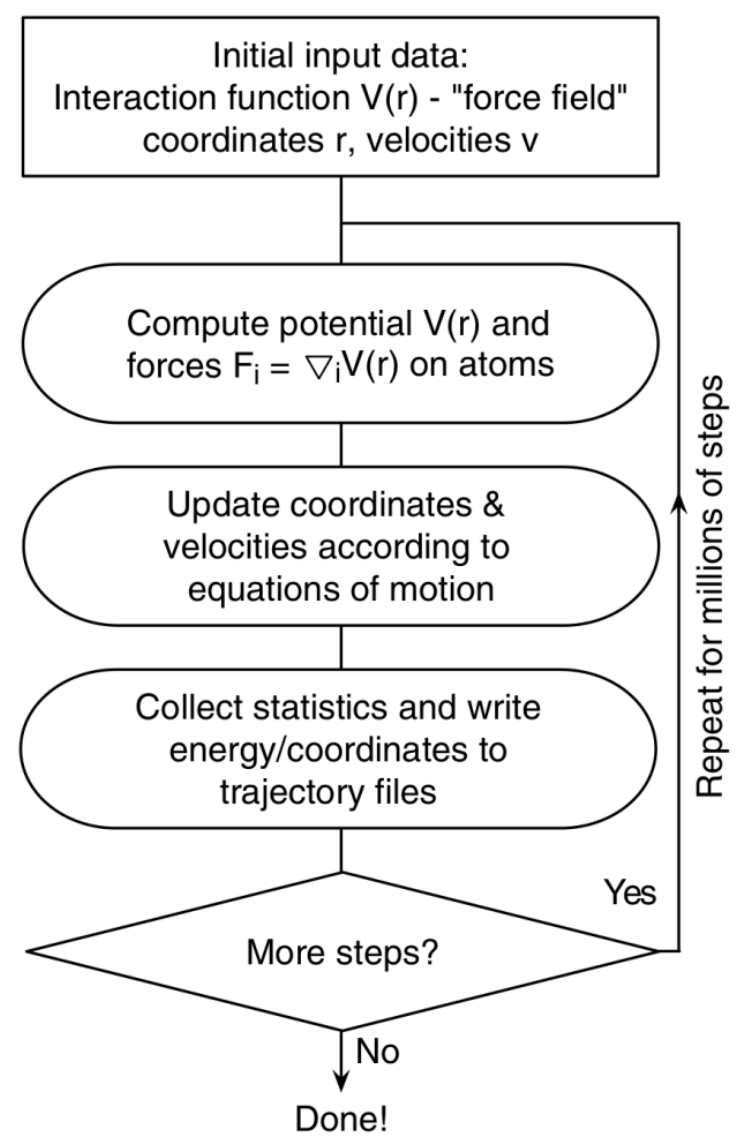

(Lindahl, E., 2008)

Figura 26: Fluxograma ilustrando os passos de uma simulação de dinâmica molecular. A idéia básica é calcular as funções de potencial relativas a cada átomo e integrar as equações de movimento de Newton para obter as novas coordenadas destes. 
O sistema de uma dinâmica geralmente é constituído por uma caixa virtual contendo a(s) molécula(s) de interesse (o objeto do estudo) e moléculas de água preenchendo o espaço vazio no interior da caixa. Para evitar artefatos oriundos do contato de moléculas com uma superfície (e.g. da caixa), geralmente as simulações ocorrem usando condições de fronteira periódica. Assim, cada molécula de água que sai pela direita reaparece na esquerda. Por esse motivo, também é importante que a caixa virtual seja suficientemente grande para impedir que moléculas interajam com suas cópias periódicas. Isso está intimamente relacionado com as interações não covalentes, que devem ser idealmente somadas junto a todos os átomos vizinhos no sistema periódico e infinito resultante (Lindahl, E., 2008). Para calcular as energias das interações de LJ, a introdução de um limite na distância é suficiente para evitar esse problema e calcular corretamente a energia potencial, uma vez que essas energias decaem rapidamente com alguma distância. Já para as interações de Coulomb, uma queda abrupta da energia acarreta em grandes erros de cálculo, pois elas ocorrem devido à potenciais eletrostáticos que interagem à longa distância. Uma alternativa muito importante para evitar esse erro de cálculo é usar o somatório de Ewald para malha de partículas (PME)(explicado na seção 3.1.2.) (Lindahl, E., 2008).

A parte mais custosa de uma simulação é a computação das interações não covalentes, pois milhões de pares devem ser avaliados a cada passo e os passos podem não serem suficientes para avaliar todas as interações. Estender o intervalo de tempo (aumentar o número de passos) é, portanto, uma maneira importante de melhorar o desempenho de uma simulação, mas infelizmente erros no cálculo da vibração entre ligações covalentes já ocorrem com um femtossegundo. Como as vibrações não são importantes na maioria das simulações, elas podem ser removidas introduzindo algoritmos de restrição como o SHAKE ou LINCS (Lindahl, E., 2008). Além disso, o ato de fixar o comprimento das ligações covalentes é uma aproximação melhor para a quantificação mecânica do estado fundamental.

A primeira dinâmica foi realizada em 1957 mas somente na década de 70 foi possível simular água e biomoléculas (Lindahl, E., 2008).

\subsubsection{Somatório de Ewald para malha de partícula (PME)}

O PME permite calcular as interações eletrostáticas infinitas através da separação dessas interações em termos de curta e longa distância (Cerutti, D.S. et al., 
2009). Ao termo de curta distância é imposto um corte de distância no cálculo da função de energia potencial. No entanto, ao contrário dos métodos tradicionais, o potencial fora do corte limite não decai abruptamente para zero, mas, ao invés, é resolvido usando uma função de comutação, ou "troca", que leva o potencial suavemente para zero ao longo de uma certa distância (geralmente 1 a 2 Å). Na prática, esse termo de longa distância é tratado mapeando-se as cargas dos núcleos em uma malha no espaço recíproco e calculando o potencial por meio da transformada de Fourier.

\subsubsection{Ressonância plasmônica de superfície (SPR)}

A tecnologia SPR envolve a ligação de uma molécula analito a um "sensor chip" e posterior aplicação de uma molécula ligante, cuja interação deverá ser avaliada junto à molécula imobilizada ao chip. A ligação de moléculas à superfície do sensor chip gera uma resposta proporcional à massa dessas moléculas. As mudanças na quantidade ligada podem ser detectadas até picogramas por milímetro quadrado na superfície do chip. Essa resposta é dada por uma unidade arbitrária denominada RUs, que deve aumentar no caso de haver interação entre o analito e o ligante. Ao fim da aplicação do ligante, ocorre a fase de dissociação, que depende da cinética e afinidade entre as moléculas.

\subsection{Material \& Métodos}

\subsubsection{Rodando a simulação de dinâmica molecular}

A dinâmica molecular atomística foi realizada usando o pacote de programas GROMACS (Kutzner, C., Czub, J. \& Grubmuller, H., 2011; Pronk, S. et al., 2013) versão 4.5.3 para o modelo Dock1 da toxina Cry1Ab e versão 4.6.3 para o modelo Dock2 da mesma toxina, ambos usando a opção de dupla precisão. As mudanças entre essas versões não acarreta em diferenças nas simulações, como é especificado nas notas de atualização (Anexo 4 da Seção I), pois a principal diferença é o processamento de dados usando Unidades de Processamento Gráfico (GPUs), que não se aplica a este trabalho. Ambos os modelos submetidos à dinâmica possuíam os heteroátomos de $\mathrm{Ca}^{2+}$ ligados ao receptor BT- $\mathrm{R}_{1}$. Essas duas proteínas foram escolhidas para a dinâmica por serem modelos há muito tempo descritos na literatura e por participarem nos dois modelos de docking, o que facilita a comparação entre os modelos. 
A única modificação feita aos arquivos pdb após os dockings foi a deleção dos dois primeiros ectodomínios de CR, uma vez que essas regiões estão distantes da interface de interação (Figura 23) e aumentariam consideravelmente os cálculos da dinâmica. $\mathrm{O}$ arquivo pdb de ambos os dockings, oriundos diretamente do servidor ClusPro 2.0, foram preparados e submetidos à dinâmica molecular seguindo as linhas de comando do Anexo 5 da Seção I. Em sua totalidade, essas linhas de comando promovem as seguintes funções:

1. Cria uma topologia para os átomos contidos no arquivo pdb usando parâmetros de um campo de força. Isso gera uma nova organização dos átomos em um novo arquivo que será usado pelo GROMACS. Este arquivo contém uma nova catalogação dos átomos e possui as informações e parâmetros de todas as ligações em que estes estão envolvidos, bem como a maneira que será tratada a densidade eletrônica de cada átomo durante a dinâmica. O campo de força utilizado foi o GROMOS 43a1. Trata-se de um campo de força desenhado e parametrizado para proteínas em água. Por se tratar de um campo de força de "átomos unificados" (united atoms), ele não inclui parametrização para átomos de hidrogênio apolares (somente os polares estão definidos no campo) e trata os átomos envolvidos em interações de Coulomb (elétricas) como cargas pontuais. Além disso, ele não inclui os parâmetros para íons de cálcio. A introdução desse parâmetro foi feita manualmente dentro do arquivo do campo de força, inserindo:

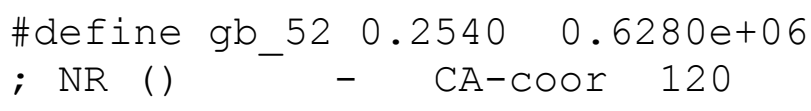

em :

\section{usr/loca/gromacs/share/gromacs/top arquivo gromos43al.ff}

2. Cria uma caixa virtual e a enche de moléculas de solvente. Neste trabalho o solvente é composto por moléculas de água SPC (de carga pontual única). A caixa virtual foi criada no formato triclínico com as dimensões 11,31937 x 11,09782 x $11,58943 \mathrm{~nm}$ para Dock1 e 9,103 x 12,102 x 11,462 nm para o Dock2. Ambas as caixas usam condições periódicas de contorno, ou seja, se uma molécula contida na caixa estiver se movendo em direção a uma de suas paredes, esta irá "atravessar" a parede e "surgir" na parede oposta, impedindo eventuais artefatos aos cálculos. 
3. Calcula a carga total do sistema e insere íons de cargas opostas para contrabalancear uma eventual carga, equilibrando o sistema. A carga de ambos os sistemas estavam em 8, de maneira que foram adicionados oito íons de sódio $\left(\mathrm{Na}^{+}\right)$para deixar a carga de cada sistema igual à zero.

4. Promove a minimização de energia do sistema usando parâmetros do arquivo mdp de minimização (Anexo 6 da Seção 1.). Trata-se de uma minidinâmica que visa reduzir ao máximo a energia potencial do sistema usando o algoritmo de gradiente descendente.

5. Faz a termalização do sistema usando parâmetros do Anexo 7 da Seção I. Trata-se do aumento gradual de temperatura usando algumas restrições. Este processo visa a deixar seu sistema na temperatura em que será rodada a dinâmica e evita que o cálculo repentino e simultâneo de todos os átomos, à temperatura final, cause a desestabilização (literalmente, uma explosão) do sistema. Esse processo dura 35 picossegundos e a temperatura final alcançada foi de $300 \mathrm{~K}$.

6. Inicia a dinâmica a $310 \mathrm{~K}$ usando parâmetros do Anexo 8 da Seção I. Importante ressaltar que as interações eletrostáticas de longa distância foram tratadas usando PME (Particle-Mesh Ewald). Um total de 136832 átomos foram simulados na dinâmica molecular de Dock1 e 122369 átomos na dinâmica molecular de Dock2, durante 76 nanossegundos.

A dinâmica foi dividida em várias partes para facilitar a manipulação no tamanho dos arquivos gerados e poder retomar os cálculos em caso de quedas de energia. A lista de eventos e arquivos produzidos durante a dinâmica está no Anexo 9 da Seção I.

\subsubsection{RMSD e Energias}

Como o objetivo desse trabalho foi obter um modelo caracterizando a interação de duas moléculas, o melhor cálculo que poderia ser feito seria a medida da energia livre de ligação. No entanto o cálculo dessa energia não é trivial e necessita rodar no mínimo três simulações de dinâmica em paralelo. Para fins de uma publicação, no entanto, existem outras alternativas para quantificar a energia de interação entre duas moléculas. Uma alternativa viável seria decompor a energia de Coulomb (eletrostática) de curta e/ou longa distância para todos resíduos de aminoácidos e analisar aqueles que participam da interface de interação. Essas medidas ainda estão sendo feitas e não 
entrarão neste documento. Aqui foram avaliadas apenas as energias de curta distância para os termos de Coulomb e Lennard-Jones entre as proteínas inteiras. Ou seja, a energia de curta distância para BT-R1 e Cry1Ab, não havendo a decomposição por aminoácidos nem a avaliação do termo de longa distância. Para isso foram definidos grupos de energia nos arquivos mdp referente às duas proteínas de interesse.

As medidas de RMSD foram feitas usando o programa g_rms_d do pacote GROMACS. Em todas as medidas, a totalidade dos átomos de uma proteína foi "ajustada" aos átomos de sua cadeia principal.

\subsubsection{Matriz de contatos}

Uma matriz de contatos mede a distância entre átomos para cada quadro da simulação e retorna um gráfico de píxeis com a média de todas essas distâncias, onde distâncias curtas geram píxeis em tom de branco e distâncias longas geram píxeis negros. O chamado "g_mdmat", usado para gerar a matriz de contatos, foi utilizado usando a tag "-dt 50" (50 ps) para reduzir a quantidade de quadros analisados.

\subsubsection{Análise de ligações de hidrogênio}

O GROMACS permite ao usuário mapear ligações de hidrogênio (LdH) de várias maneiras diferente. Uma das mais úteis é avaliando a existência de $\mathrm{LdH}$ em função do tempo. A existência de uma ligação de hidrogênio é definida por um critério espacial e geométrico onde $r \leq 3,5 \mathrm{~nm}$ e $\alpha \leq 30^{\circ}$, conforme a Figura 27:

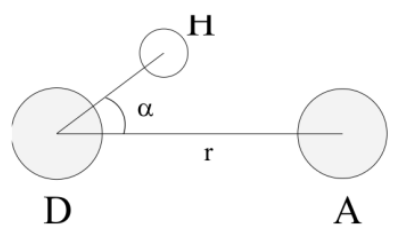

Figura 27: Critério geométrico para a existência de uma ligação de hidrogênio.

Para isso gera-se uma matriz contendo no eixo Y todas as $\mathrm{LdH}$, especificando o átomo doador, o hidrogênio doado e o átomo aceitador, e no eixo $\mathrm{X}$ o tempo decorrido da simulação dividido pela quantidade de quadros usados pra coletar informações. Para cada quadro onde uma LdH está presente, marca-se um ponto vermelho na matriz. Dado que a dinâmica de 76 ns foi dividida em 152000 quadros, analisar essa matriz 
visualmente é completamente inviável. Portando foi utilizado o script "plot_hbmap.py", feito por Justin Lemkul e hospedado no endereço eletrônico: (http://www.bevanlab.biochem.vt.edu/Pages/Personal/justin/scripts.html). Esse script lê a matriz e retorna a porcentagem de existência de uma LdH durante a dinâmica, bem como traduz o índice de átomos e retorna o nome e número dos resíduos que participam de cada ligação. Podemos saber, por exemplo, que a ARG256 doou um hidrogênio para o GLU360 durante 80 \% da simulação (exemplo hipotético). Todas as medidas relativas à análise de LdH foram feitas usando as configurações default do GROMACS.

\subsubsection{Pontes salinas}

Foi usado o programa g_select para selecionar todos os nitrogênios e oxigênios da cadeia lateral de resíduos de arginina, lisina, ác. aspártico, ác. glutâmico e histidina (ex. "proteins" and ( $\mathrm{R}$ or $\mathrm{K}$ or $\mathrm{H}$ or $\mathrm{D}$ or $\mathrm{E})$ and $(\mathrm{N}$ or $\mathrm{O}$ (da cadeia lateral))). Foram criados novos arquivos xtc e tpr com esses átomos e o programa g_saltbr foi rodado com a tag -t 0.4 (Kumar, S. \& Nussinov, R., 2002).

\subsubsection{Ensaio in vitro utilizando ressonância plasmônica de superfície (SPR)}

Em uma tentativa de validar as interações observadas durante a dinâmica, foram sintetizados alguns peptídeos correspondendo às RUL para utilização em ensaios usando SPR. Os ensaios foram feitos utilizando o equipamento Biacore X100, que monitora a interação entre duas ou mais moléculas em tempo real. Dessa maneira, o peptídeo Ab2.5 foi imobilizado covalentemente, por meio da extremidade N-terminal, em um chip modelo "CM5". A reação ocorreu em pH 5,5 usando os reagentes fornecidos pela empresa GE healthcare e imobilizou aproximadamente 4000 unidades do peptídeo.

\subsection{Resultados e Discussão}

Cinco considerações antes de interpretar os resultados aqui contidos:

1. Os sistemas analisados contém uma quantidade considerável de átomos que dificultam a velocidade dos cálculos de dinâmica molecular. Isso unido ao fato de esses cálculos terem sido rodados em desktops locais (computadores de mesa comuns) impossibilitou a triplicata dos dados. Algo que deverá (e vai) ser feito para a publicação de um artigo. 
2. No sistema contendo Dock2, houve interação de cópias periódicas em uma pequena porção do sistema, ou seja, ocorreu um artefato oriundo da técnica utilizada para tratar a caixa d'água como infinita. Esse artefato é facilmente contornado, mas implica em um cuidado maior ao analisar a energia do sistema inteiro, pois se deve subtrair a energia oriunda dessa interação e isso não foi feito para a elaboração desse documento.

3. O receptor BT-R1 modelado advém da porção extracelular da caderina e embora isso seja conveniente, traz o viés de que a extremidade C-terminal dessa molécula tem mais graus de liberdade do que ela normalmente teria se tivesse o restante de seus aminoácidos inseridos na membrana. Logo, também devemos interpretar as interações dos últimos 10 resíduos de aminoácidos C-terminais com ceticismo.

4. Os dados de RMSD indicam que o tempo observado para os sistemas não foi suficiente para entrar em equilíbrio. Novamente, isso advém da limitação de tempo e poder computacional da máquina utilizada. Embora o sistema como um todo não tenha chegado ao equilíbrio, a análise de RMSD considerando apenas as regiões de interação mostram que grande parte das interações foi estável. Além disso, o RMSD do sistema como um todo pode ter sido prejudicado pela falta de parametrização dos íons de cálcio, que não permaneceram ligados e diminuem consideravelmente a rigidez da caderina, aumentando o RMSD da dinâmica. Esse aumento de flexibilidade já havia sido observado por Sotomayor \& Schulten (2008) e corrobora com este trabalho.

5. É importante mencionar que foi obtida uma configuração um pouco diferente em relação ao ectodomínio 12 (CR12) de BT-R 1 quando foi comparado ao obtido na modelagem feita por Ibrahim et al. (2010). Mais especificamente, a região correspondendo a ${ }_{1385}$SAITYAIDY $_{1392}$ não alcançou uma conformação de fita- $\beta$ devido aos resíduos ${ }_{1390} \mathrm{IDY}_{1392}$ terem assumido uma conformação de loop em nosso modelo inicial. No entanto, essa pequena discrepância desapareceu assim que a dinâmica começou e a região ${ }_{1385}$ SAITYAIDY ${ }_{1392}$ notavelmente assumiu a conformação de fita- $\beta$, o que indica que a diferença observada era trivial. $\mathrm{O}$ mais importante é que isso não influenciou no restante dos resultados, pois todas as outras estruturas secundárias e configurações iniciais já estavam de acordo com as predições feitas e também corroboravam com a estrutura modelada por Ibrahim et al. (2010). 

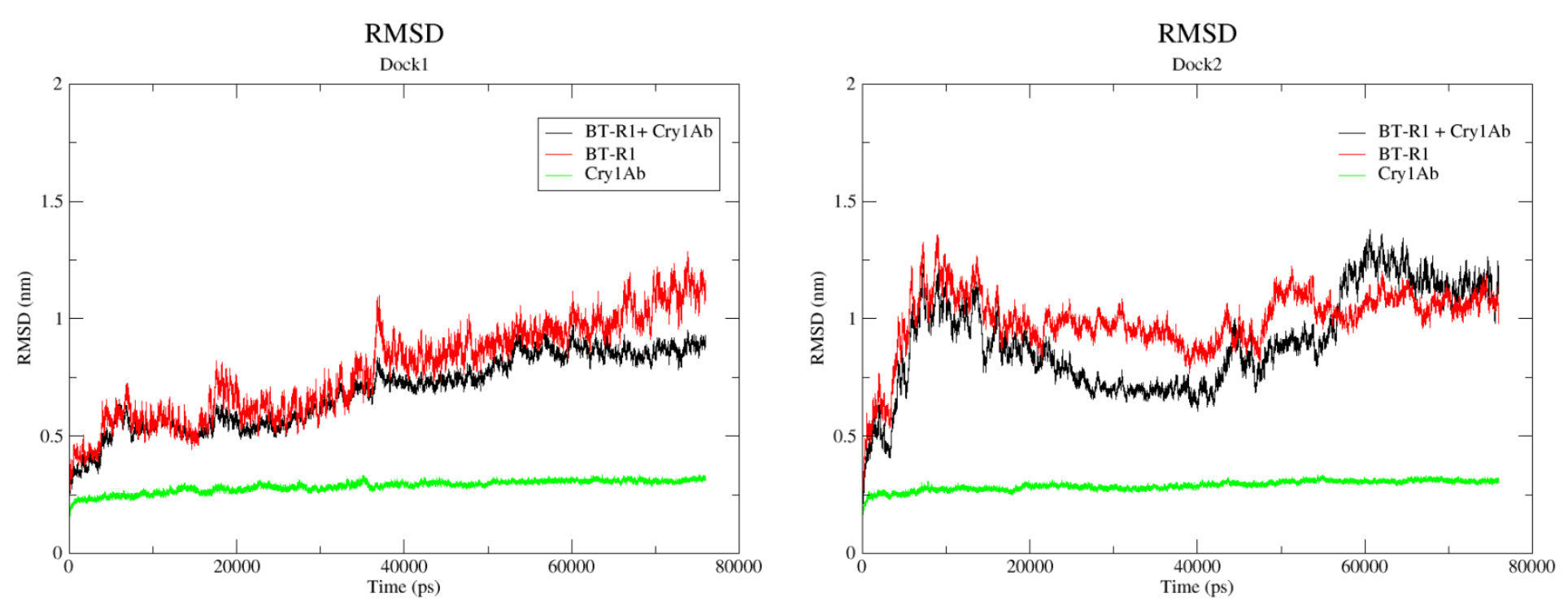

Figura 28: Medidas de RMSD para Dock1 e Dock2. Em preto o RMSD foi medido para o complexo BT-R ${ }_{1} /$ Cry1Ab. Em vermelho está ilustrada a contribuição do receptor para o RMSD e em verde, a contribuição da toxina Cry1 Ab.

A primeira análise feita após o fim das dinâmicas foi uma medida de RMSD (Figura 28). É perceptível pelo RMSD do complexo BT-R 1 Cry1Ab, em Dock1 e Dock2, que o sistema não alcançou o equilíbrio após 76 ns. A média de RMSD para o complexo em Dock1 foi de 0,688 nm e 0,902 nm para o complexo em Dock2, considerando o início da dinâmica (que geralmente é excluído do cálculo de RMSD por se tratar de uma fase instável). Observando com mais detalhe para as contribuições individuais de RMSD do receptor BT- $\mathrm{R}_{1}$ e da toxina Cry1 $\mathrm{Ab}$, é possível notar que o receptor é o responsável pela instabilidade do sistema (Tabela 6). Dado que em ambos os experimentos (Dock1 e Dock2) as toxinas permaneceram ligadas durante toda a simulação e que a contribuição de Cry1 Ab (em verde) para o RMSD foi mínima, o que está sendo observado são mudanças nas regiões do receptor que não participaram da ligação à toxina. 


\begin{tabular}{|c|c|c|}
\cline { 2 - 3 } \multicolumn{1}{c|}{} & \multicolumn{2}{c|}{ RMSD médio $(\mathrm{nm})$} \\
\cline { 2 - 3 } \multicolumn{1}{c|}{} & Dock1 & Dock2 \\
\hline BT-R1/Cry1Ab & 0.688 & 0.902 \\
BT-R1 & 0.784 & 0.995 \\
Cry1Ab & 0.286 & 0.289 \\
\hline
\end{tabular}

Tabela 6: Médias de RMSD durante 76 nanossegundos de simulação. As medidas foram feitas sem excluir o início da dinâmica.

Ao analisar a trajetória total da simulação é possível ver que a maioria dos íons de $\mathrm{Ca}^{2+}$ (4 de 6) não permaneceu ligado ao receptor. Como já havia sido relatado por Sotomayor \& Schulten (2008), o $\mathrm{Ca}^{2+}$ é responsável pelo enrijecimento da caderina e isso pode ser observado por simulações de dinâmica molecular. Em um experimento paralelo (dados não mostrados), o modelo Dock1 foi submetido à outra simulação de 50 ns, mas desta vez com os íons de cálcio forçados a permanecerem ligados aos aminoácidos de $\mathrm{BT}-\mathrm{R}_{1}$ (em sua maioria, resíduos de ácido aspártico). Os resultados de RMSD para o complexo, receptor e toxina foram de 0,644, 0,804 e 0,277 nm, respectivamente. Esses resultados se enquadram dentro do desvio padrão (não mostrado) e, portanto, não permitem sugerir uma função estabilizadora aos íons de cálcio em Dock1. Isso pode ser devido ao fato de que a própria toxina Cry1 Ab ajuda a estabilizar o fragmento de caderina.

O que é descrito na literatura referente aos íons de cálcio e toxinas Cry é que, quando vesículas bilaminares da membrana de células de insetos são incubadas com íons $\mathrm{Ca}^{2+}$ e Cry1 Ab, formam-se cerca de $50 \%$ menos agregados de células quando comparado à incubação só com $\mathrm{Ca}^{2+}$ (Griko, N. et al., 2004). Isso sugere que Cry1 Ab interfere na função adesiva da caderina, mas não o suficiente para reproduzir, por exemplo, o efeito quelante do ácido etilenodiamino tetra-acético (EDTA) ou ácido etileno glicol-bis (b-amino-etil-eter) N,N,N9,N9- tetra-acético (EGTA). Ambos os modelos corroboram com essa ideia, pois as interfaces de interação tem a participação dos sítios de ligação ao cálcio (região entre os domínios CR). De qualquer forma, é necessário rodar uma nova dinâmica de Dock2 com os íons $\mathrm{Ca}^{2+}$ restringidos em seus sítios de ligação para poder inferir qualquer informação sobre o possível efeito estabilizante dos íons e/ou da toxina Cry1 Ab. 


\subsubsection{Mapeamento de interações intermoleculares}

Foram mapeadas todas as ligações de hidrogênio $(\mathrm{LdH})$ realizadas entre BT- $\mathrm{R}_{1} \mathrm{e}$ Cry1Ab durante as simulações de Dock1 e Dock2, conforme especificado na seção 3.2.4. Primeiramente organizou-se todos os resíduos de acordo com a sua proteína de origem e posição na estrutura primária. Dessa maneira foi possível agrupá-los em "blocos de interação" na sequência de cada proteína, cada bloco variando entre 3 e 22 aminoácidos (Figura 29).
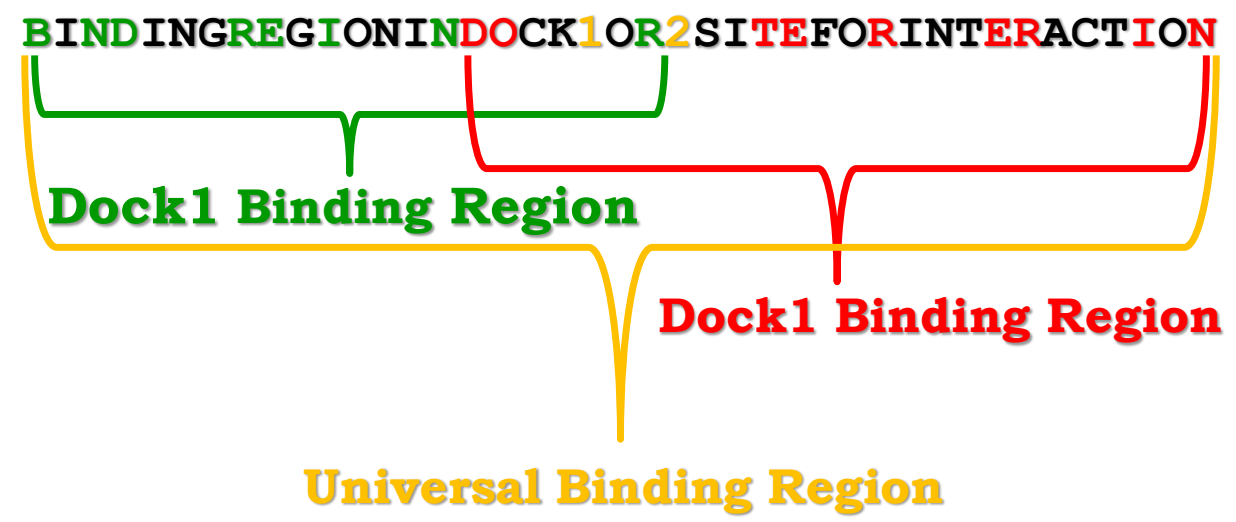

Figura 29: Representação ilustrativa da formação de uma Região de Ligação Universal (RUL ou UBR). Todos os resíduos de aminoácidos participando na formação de LdH e de pontes salinas em Dock1 (verde) e Dock2 (vermelho) foram agrupados em regiões da sequência proteica. Essas regiões de ligação puderam ser agrupadas em uma região ainda maior da sequência proteica, abrangendo até no máximo 22 resíduos de aminoácidos (amarelo). Todas as RULs receberam um nome único (e.g. CR11.1).

Alguns blocos possuem quase 50 aminoácidos, mas foram divididos em grupos

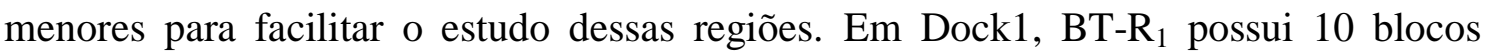
distintos de aminoácidos participando de $\mathrm{LdH}$, enquanto Cry1 Ab possui 12. Já o modelo Dock2 possui 13 blocos para o receptor e 11 para a toxina. O resumo geral da quantidade de $\mathrm{LdH}$ distintas que existiram durante a simulação, e a quantidade total de resíduos que formam os blocos, está apresentado na tabela abaixo: 


\begin{tabular}{|c|c|c|c|}
\cline { 2 - 4 } \multicolumn{1}{c|}{} & $\begin{array}{c}\text { Total de ligações } \\
\text { de hidrogênio } \\
\text { distintas }\end{array}$ & $\begin{array}{c}\text { Contribuição total de } \\
\text { resíduos de BT-R1 para } \\
\text { ligações de hidrogênio }\end{array}$ & $\begin{array}{c}\text { Contribuição total de } \\
\text { resíduos de Cry1Ab para } \\
\text { ligações de hidrogênio }\end{array}$ \\
\hline Dock1 & 1023 & 91 & 91 \\
\hline Dock2 & 1268 & 114 & 108 \\
\hline
\end{tabular}

Tabela 7: Quantidade total de ligações de hidrogênio (LdH) diferentes presente nos modelos Dock 1 e Dock2 durante a simulação e a contribuição, em resíduos de aminoácidos, de cada proteína.

A segunda parte da análise consistiu em selecionar as LdH que existiram durante a maior parte da dinâmica e avaliar se algum dos blocos de interação poderia ser um falso-positivo (um bloco que possuí apenas LdH que existiram infimamente). Para a seleção foi escolhido o corte arbitrário de $10 \mathrm{ns,} \mathrm{ou} \mathrm{seja,} \mathrm{todas} \mathrm{as} \mathrm{LdH} \mathrm{que} \mathrm{existiram} \mathrm{por}$ pelo menos $10 \mathrm{~ns}$ (de um total de $76 \mathrm{~ns}$ ) foram selecionadas. A busca por blocos falsopositivos encontrou dois candidatos na simulação de Dock2, ambos na sequência de

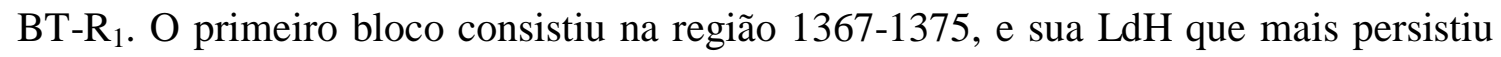
durante a dinâmica durou apenas 0,16 ns. O segundo consistiu na região 1115-1119 e, apesar de possuir uma LdH que persistiu por 1,4 ns, foi eliminado por ter interagido com a cópia periódica de toxina Cry1 $\mathrm{Ab}$, deixando o BT- $\mathrm{R}_{1}$ com 11 blocos de interação em Dock2. O interessante é que essa interação não foi observada em outras análises (e.g. matriz de contato), e parece estar envolvida com a maneira que o GROMACS computa LdH no espaço infinito. De qualquer maneira, apenas um dos resíduos desse bloco participou de uma LdH que durou mais que 0,2 ns, o que não é capaz de afetar o restante das interpretações desse trabalho.

Um total de 57 e $60 \mathrm{LdH}$ persistentes foram selecionadas para Dock1 e Dock2, respectivamente. As dez LdH mais persistentes em cada um dos modelos estão listadas na Tabela 8. Os resíduos de aminoácidos que participam das LdH persistentes foram mapeados em seus respectivos blocos de interação para facilitar a visualização de regiões mais estáveis durante a ligação entre o receptor e a toxina. 


\begin{tabular}{|c|c|c|c|c|c|c|}
\hline & \multicolumn{3}{|c|}{ Dock1 } & \multicolumn{3}{|c|}{ Dock2 } \\
\hline & $\begin{array}{l}\text { Resíduo de } \\
\text { Cry1Ab }\end{array}$ & $\begin{array}{c}\text { Resíduo de } \\
\text { BT-R1 }\end{array}$ & $\%$ & $\begin{array}{l}\text { Resíduo de } \\
\text { Cry1Ab }\end{array}$ & $\begin{array}{c}\text { Resíduo de } \\
\text { BT-R1 }\end{array}$ & $\%$ \\
\hline 1 & ARG501 & ASP1298 & 81,505 & GLU288 & SER1384 & 56,265 \\
\hline 2 & VAL488 & GLU1259 & 73,791 & LYS490 & ASP1393 & 55,170 \\
\hline 3 & SER290 & GLU1260 & 58,935 & SER293 & ASP1391 & 51,489 \\
\hline 4 & GLY289 & GLN1261 & 57,938 & TYR268 & TYR1392 & 50,518 \\
\hline 5 & SER438 & GLU1253 & 52,942 & SER290 & ALA1413 & 48,083 \\
\hline 6 & ASN376 & VAL1397 & 46,847 & ASN442 & TYR1388 & 47,042 \\
\hline 7 & VAL445 & ALA1444 & 46,807 & THR486 & ALA522 & 46,679 \\
\hline 8 & ILE375 & VAL1396 & 46,565 & ALA284 & SER1384 & 43,801 \\
\hline 9 & ASN376 & GLN1445 & 42,404 & GLN285 & GLU1382 & 41,585 \\
\hline 10 & GLN154 & ARG1205 & 38,435 & ASP222 & SER1315 & 39,883 \\
\hline
\end{tabular}

Tabela 8: As dez ligações de hidrogênio mais persistentes de Dock1 e Dock2. A porcentagem é referente à existência de cada ligação no intervalo de 76 nano segundos.

Uma comparação entre os blocos de interação de cada modelo revelou similaridade entre as regiões, de maneira que foi possível unir blocos próximos de ambos os modelos em uma um bloco maior, denominado região universal de ligação $(R U L)$ (Figura 29). Mais ainda, foi possível organizar essas regiões de acordo com sua distribuição nos diferentes domínios de $\mathrm{BT}-\mathrm{R}_{1}$ e Cry1Ab. As RULs pertencentes à Cry1 $\mathrm{Ab}$ recebem o prefixo "Ab" seguido de um algarismo correspondente a um dos três domínios e por fim um "ponto algarismo" referente à ordem da região na sequência de resíduos de aminoácidos. Por exemplo, a RUL Ab2.5 corresponde à região 5 de Cry1 Ab pertencente ao domínio II. Da mesma forma foi feito para as RULs pertencentes ao receptor $\mathrm{BT}-\mathrm{R}_{1}$, com a única diferença que estas receberam o prefixo "CR" (referente aos ectodomínios repetitivos de caderina), e.g., CR12.1. Com essas informações foi montada a Tabela 9. 


\begin{tabular}{|c|c|c|c|c|}
\hline \multicolumn{5}{|c|}{ BT-R1 } \\
\hline \multirow{2}{*}{$\begin{array}{c}\text { Epitopo de } \\
\text { Ligação }\end{array}$} & \multirow{2}{*}{ Posição } & Região Universal de Ligação & Região em Dock1 & Região em Dock2 \\
\hline & & Sequência & Sequência & Sequência \\
\hline CR-10.1 & $1126-1139$ & TNDAVIRLARERAV & TNDAVIR & RAV \\
\hline CR-10.2 & $1159-1177$ & DPDGLHAGVVTFQVVGDEE & $\mathrm{DEE}$ & DPDGLHAG \\
\hline CR-10.3 & $1203-1219$ & EIREFRITIRATDQGTD & EIREFR & QGTD \\
\hline CR-11.1 & $1241-1262$ & RFASSEHAVAFIEKSAGMEESH & RFASSEHAVAFIEKSAGMEESH & RFASSEHAVAF \\
\hline CR-11.2 & $1263-1285$ & QLPLAQDIKNHLCEDDCHS IYYR & QLPLAQDIKNHLCEDDCHS IYYR & QLPLAQDIKNHLCED \\
\hline CR-11.3 & $1291-1307$ & SEGHFGLDPVRNRLFLK & EGHFGLDPVRNRLFLK & SEGH \\
\hline CR-11.4 & $1312-1327$ & REQSASHTLQVAASNS & REQSASHTLQVAASNS & REQSASHT \\
\hline CR-12.1 & $1340-1351$ & TVTVTVREADPRP & TVTVTVREADPR & TVTVREA \\
\hline CR-12.2 & $1381-1403$ & SEGSAITYAIDYDTMVVDPSLEA & GSAITYAIDYDTMVVD & SEGSAITYAIDYDTMVVDPSLEA \\
\hline CR-12.2/12.3 & $1393-1415$ & DTMVVDPSLEAVRQSAFVLNAQT & - & DTMVVDPSLEAVRQSAFVLNAQT \\
\hline CR-12.3 & 1404-1425 & VRQSAFVLNAQTGVLTLNIQPT & - & VRQSAFVLNAQTGVLTLNIQPT \\
\hline CR-12.4 & $1437-1450$ & TATDTAGAQDRTDV & TATDTAGAQDRTDV & TDTAGAQDRTD \\
\hline
\end{tabular}

\begin{tabular}{|c|c|c|c|c|}
\hline \multicolumn{5}{|c|}{ Cry1Ab } \\
\hline \multirow{2}{*}{$\begin{array}{l}\text { Epitopo de } \\
\text { Ligação }\end{array}$} & \multirow{2}{*}{ Posição } & Região Universal de Ligação & Região em Dock1 & Região em Dock2 \\
\hline & & Sequência & Sequência & Sequência \\
\hline Ab1.1 & $81-95$ & EQLINQRIEEFARNQ & NQRIEEFARNQ & EQLINQRIEEFARNQ \\
\hline Ab1.2 & $146-154$ & PLFAVQNYQ & PLFAVQNYQ & PLFAVQNY \\
\hline Ab1.3 & $204-219$ & TDHAVRWYNTGLERVW & TDHAVRWYNTGLER & RWYNTGLERVW \\
\hline Ab1.4 & $220-233$ & GPDFRDWIRYNQFR & RDWIRYNQFR & GPDFRDWIRYNQFR \\
\hline $\mathrm{Ab} 2.1$ & $279-295$ & SFRGSAQGIEGSIRSPH & RGSAQGIEGSIRSPH & SFRGSAQGIEGS IRSPH \\
\hline Ab2.2 & $308-320$ & DAHRGEYYWSGHQ & DAHRGEYYWS & DAHRGEYYWSGHQ \\
\hline Ab2.3 & $337-350$ & LYGTMGNAAPQQRI & YGTMGN & LYGTMGNAAPQQRI \\
\hline Ab2.4 & $369-379$ & RPFNIGINNQQ & RPFNIGINNQQ & - \\
\hline Ab2.5 & $434-449$ & SMFRSGFSNSSVSIIR & SMFRSGFSNSSVSIIR & RSGFSNSSV \\
\hline Ab3.1 & $483-504$ & GSGTSVVKGPGFTGGDILRRTS & SGTSVVKGPGFTGGDILRRT & GSGTSVVKGPGFTGGDILRRTS \\
\hline Ab3.2 & $552-567$ & SATMSSGSNLQSGSFR & SSGSNLQ & SATMSSGSNLQSGSER \\
\hline Ab3.3 & 593-598 & SGNEVY & EVY & SGNEVY \\
\hline
\end{tabular}

Tabela 9: Regiões Universais de Ligação (RULs) e seus blocos equivalentes em Dock1 e Dock2. As RULs recebem o prefixo "Ab" ou "CR" seguido de um algarismo correspondente número de seu domínio e por fim um "ponto algarismo" referente à ordem da região na sequência de aminoácido. Por exemplo, a RUL Ab2.5 corresponde à região 5 de Cry1 Ab pertencente ao domínio II. 
Usando as RULs, foi feito uma nova medida de RMSD para o receptor BT$\mathrm{R}_{1}$ (Figura 30 e Figura 31). O objetivo dessa avaliação foi comparar o RMSD de RULs individuais com o RMSD do receptor inteiro para ver se existem regiões da interface de ligação que estão estabilizadas por Cry1 $\mathrm{Ab}$, indicando potenciais pontos de afinidade e especificidade. Além de usar o receptor "inteiro" como referência, foi usado o RMSD correspondente a todas as RULs como controle. Não foram feitas novas medidas de RMSD para Cry1Ab pois já havia sido observada pouca variação para essa proteína (Figura 28).
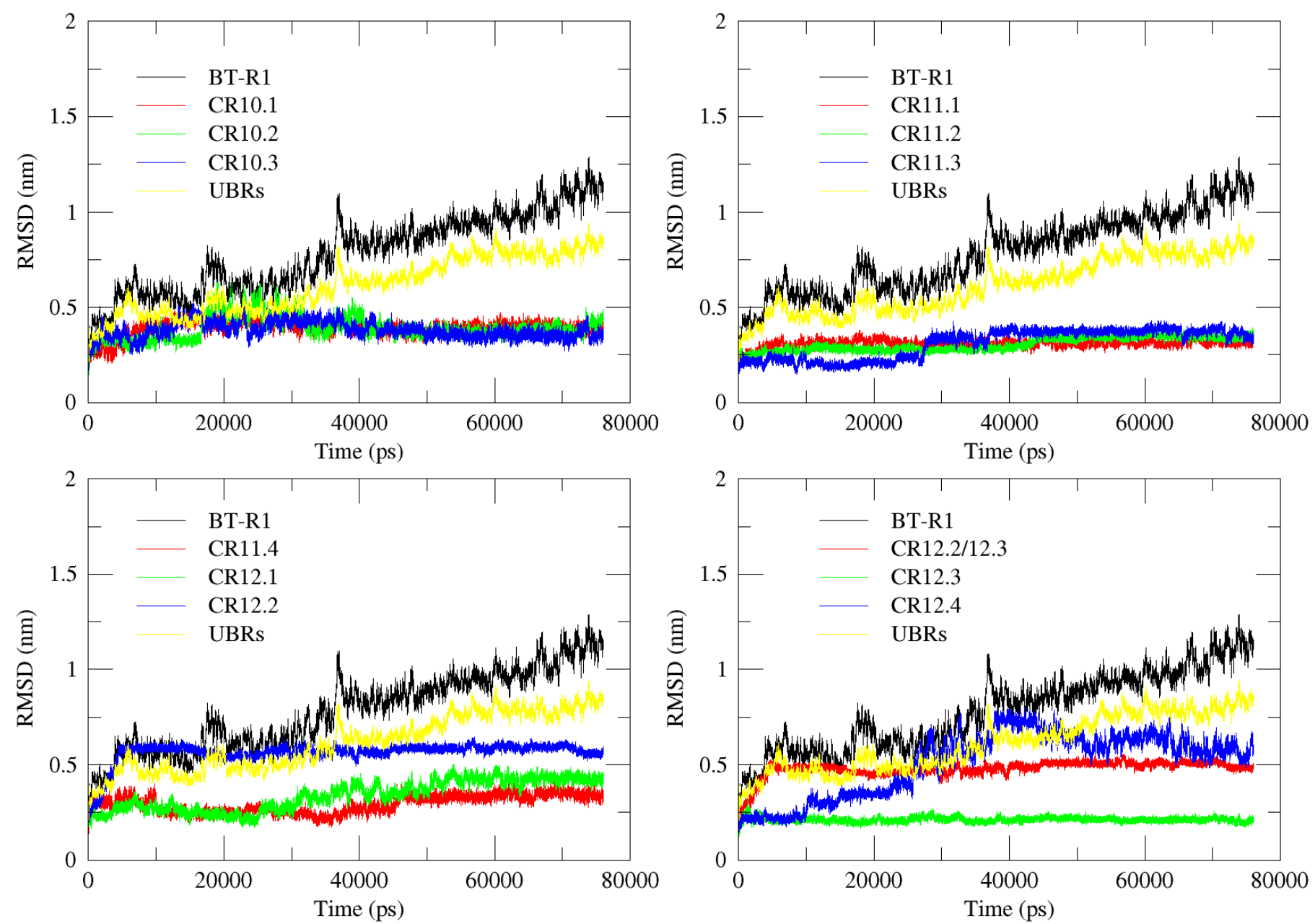

Figura 30: Medidas individuais de RMSD para RULs de BT-R em Dock1. Foi usado com controle o

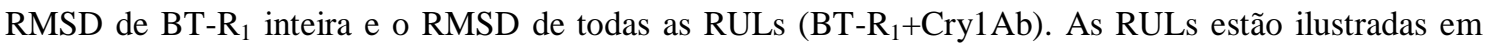
amarelo sob a legenda "UBRs" devido à sua tradução para o inglês.

O primeiro fato importante de se notar nos novos gráficos de RMSD é que a medida feita com a totalidade das RULs, de BT- $\mathrm{R}_{1}$ e Cry1 $\mathrm{Ab}$, segue o mesmo perfil do

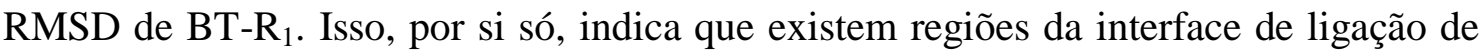


BT-R1 que sofreram perturbações mesmo após a ligação a Cry1Ab. Só é possível inferir isso devido ao resultado prévio da medida de RMSD de Cry1 Ab, que mostrou que essa toxina permanece estável durante toda dinâmica. Analisando atentamente, as novas medidas indicam justamente a participação de três RULs na perturbação de BT-R $\mathrm{R}_{1}$ Nos dois gráficos inferiores da Figura 30 é possível perceber que CR12.2 está relacionada com as perturbações que ocorrem nos primeiros $10 \mathrm{~ns}$. Da mesma forma com CR10.2 (gráfico superior esquerdo), aos cerca de $20 \mathrm{ns,} \mathrm{e} \mathrm{com} \mathrm{CR12.4} \mathrm{(inferior} \mathrm{direito),} \mathrm{entre} 30$ e 40 ns. Dessas três RULs, a única que não conseguiu estabilizar foi CR12.4, o que é interessante considerando que ela iniciou a simulação de forma estável e permaneceu assim até os primeiros $10 \mathrm{~ns}$. Uma análise da trajetória da simulação pode elucidar melhor o mecanismo que acarretou essa mudança. De qualquer forma, a estabilização das outras duas RULs é um bom indicativo de que a ligação gerada em Dock1 é energeticamente favorável (Figura 30).
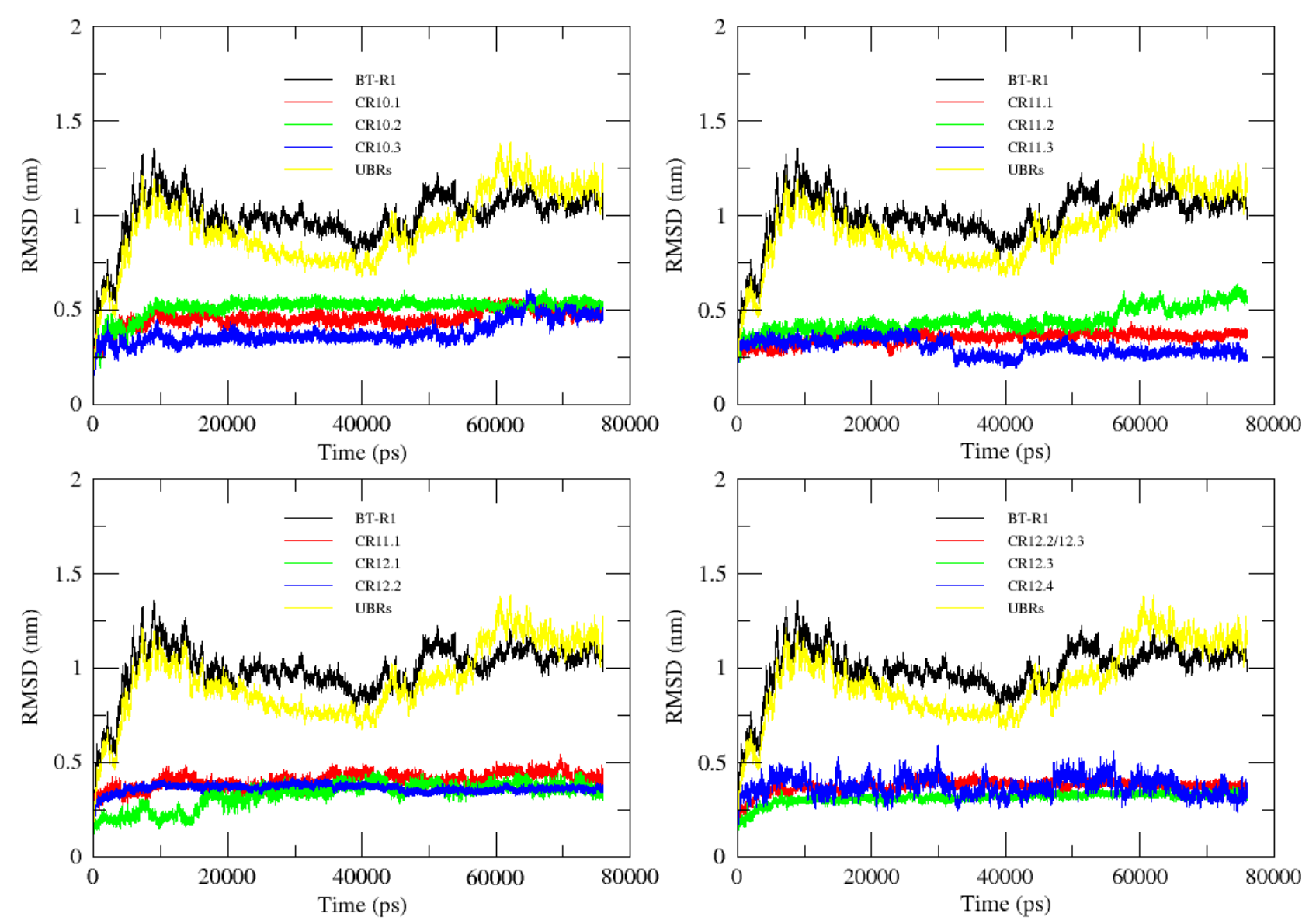

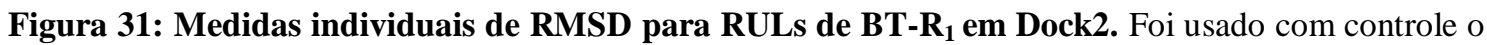
RMSD de BT- $\mathrm{R}_{1}$ inteira e o RMSD de todas as RULs . 
As análises individuais das RULs em Dock2 exemplificam como as interfaces de interação podem ser estáveis. Mesmo com médias de RMSD 30\% maiores que o Dock1 (Tabela 6), as interfaces de interação de BT- $\mathrm{R}_{1}$, como um todo, são mais estáveis em Dock2. No entanto, estes resultados não explicam porque o RMSD de todas as RULs

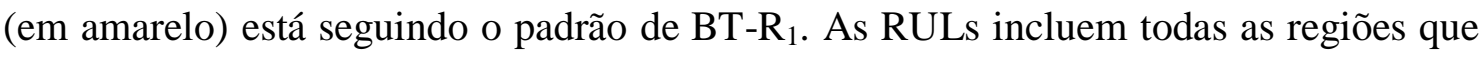
foram analisadas individualmente para $B T-R_{1}$ e mais as RULs de Cry1 Ab. Isso leva a crer que estão havendo perturbações na toxina, mas ao mesmo tempo as medidas de RMSD da toxina inteira são estáveis de acordo com os primeiros experimentos. Essa questão ainda necessita de melhores esclarecimentos.

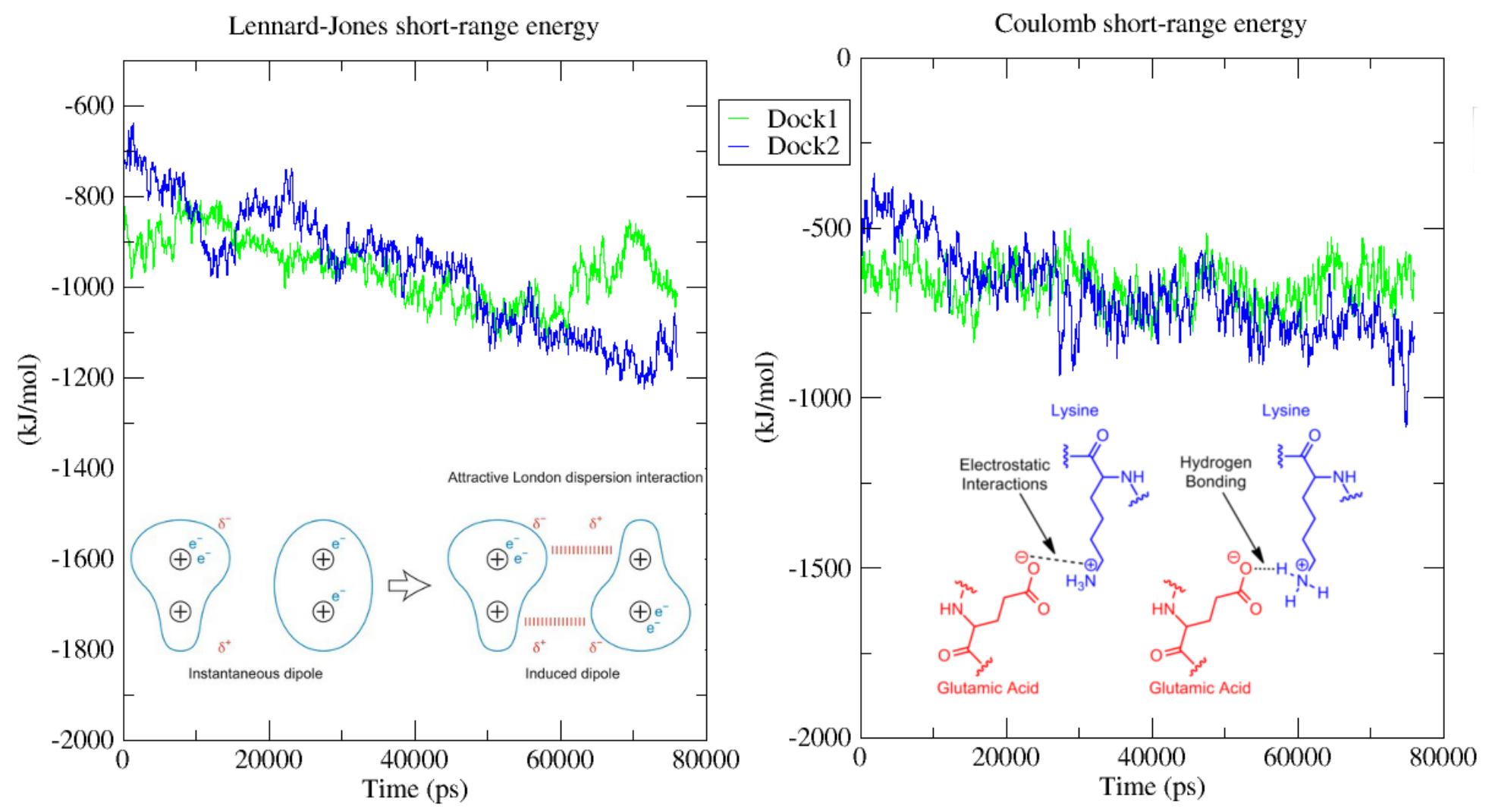

Figura 32: Energias intermoleculares de dispersão (Lennard-Jones) e eletrostáticas (Coulomb) entre BT-R $\mathbf{R}_{1}$ Cry1Ab.

As forças envolvidas na interação entre duas proteínas são dadas pelas energias de curto alcance. Essas energias são medidas por meio dos termos de Lennard-Jones e Coulomb, cujas principais interações são as dispersões de London e eletrostáticas, respectivamente. Ambos os modelos estão reduzindo suas energias com relação ao tempo e ainda não parecem ter chegado ao estado minimamente energético (Figura 32). Isso é interpretado no GROMACS como sinal de atração entre as duas moléculas e 
sugerem que ambos os modelos são favorecidos energeticamente, bem como termodinamicamente plausíveis.

\subsubsection{Integrando a matriz de contatos.}

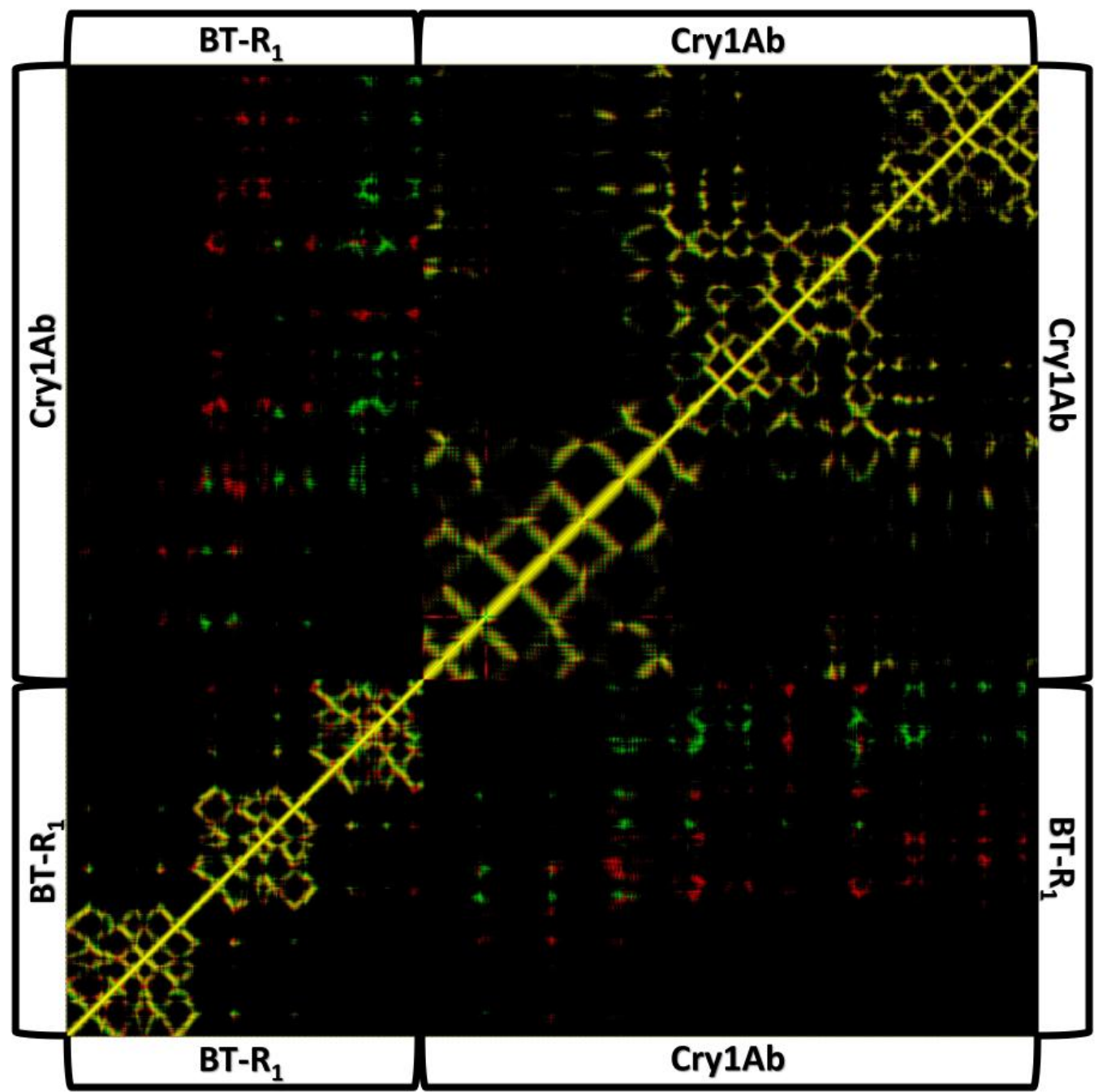

Figura 33: Matriz de contatos intra- e intermoleculares entre resíduos de BT- $R_{1}$ e Cry1Ab. As matrizes de Dock1 (vermelho) e Dock2 (verde) foram sobrepostas. Os contatos intramoleculares aparecem em sua maioria sobrepostos (amarelo), enquanto os contatos intermoleculares ressaltam a diferença entre as interfaces de interação dos dois modelos.

Uma matriz de contatos mede a distância entre átomos para cada quadro da simulação e retorna um gráfico de píxeis com a média de todas essas distâncias, onde distâncias curtas geram píxeis em tom de branco e distâncias longas geram píxeis negros. As matrizes de contatos de Dock1 e Dock2 estão apresentadas acima, onde o eixo $\mathrm{X}$ e $\mathrm{Y}$ correspondem às sequência de aminoácidos de $\mathrm{BT}-\mathrm{R}_{1}$ e Cry1 $\mathrm{Ab}$, conforme ilustrado na Figura 33. 
Os pontos coloridos (geralmente são brancos) dessa matriz nos informam a média de todas as distâncias entre resíduos de aminoácidos da interface de interação (Figura 33). Uma informação particularmente interessante é de que existem pontos que são exclusivamente contatos hidrofóbicos. Dentre as características que governam a interação entre duas proteínas, sabe-se que sítios hidrofóbicos na superfície proteica apresentam tendência a se unirem, formando "conexões hidrofóbicas" (Kysilka, J. \& Vondrasek, J., 2012).

Em meio aquoso, esses sítios hidrofóbicos expostos ao solvente normalmente são circundados por resíduos de aminoácidos polares e carregados, de maneira que eles se fecham da exposição à água e os resíduos hidrofílicos agem como "proteção" ao interagirem com o solvente polar. À medida que duas proteínas vão interagindo por potenciais eletrostáticos de longa e curta distância, regiões hidrofóbicas, antes expostas ao solvente, podem se aproximar, até que elas interagem e podem formar uma conexão hidrofóbica. O ganho energético dessas interações é considerável e estão correlacionadas com regiões de especificidade (Kysilka, J. \& Vondrasek, J., 2012), mas só ocorrem guiadas por grandes potenciais eletrostáticos. Portanto, uma maneira de avaliar as regiões de especificidade entre proteínas é mapeando-se potencias eletrostáticos próximos a sítios hidrofóbicos na superfície de interação. É importante salientar que não se trata da interação direta entre uma região de alto potencial eletrostático e um sítio hidrofóbico, mas sim uma relação indireta de potenciais eletrostáticos sobre regiões hidrofóbicas próximas da interface de interação.

Definir esses pontos não é trivial e consiste primeiramente em separar os contatos polares e contatos hidrofóbicos realizados por uma mesma região. Aqui, contato é definido como uma distância de no máximo $10 \AA$ entre regiões com alto potencial eletrostático e sítios hidrofóbicos na interface de interação. Secundariamente, é necessário definir os potenciais eletrostáticos dessas regiões. Nesse contexto, este trabalho propõe uma metodologia para conseguir distinguir entre esses dois tipos de contato e definir os potenciais eletrostáticos através de dinâmica molecular. As simulações de dinâmica molecular se tornam grandes ferramentas nessa tarefa por incluírem o fator tempo na avaliação da interação entre as proteínas. "Se uma imagem vale por mais que mil palavras", imagine o valor de milhares de imagens sobrepostas em função do tempo. Nesse caso, o docking seria uma imagem e a dinâmica molecular a sobreposição de milhares de imagens, ou quadros como são conhecidos. 
O primeiro passo para essa metodologia é a identificação de todos os contatos polares realizados entre as duas proteínas durante um intervalo de tempo. Essa etapa é mais simples de realizar devido às ligações de hidrogênio que são feitas durante esses contatos. O resumo dessas regiões está contido Tabela 9. Para separar os contatos hidrofóbicos dos contatos polares, foi utilizada uma matriz de contatos contendo todas as distâncias entre átomos das interfaces de interação (Figura 33). Após a realização de uma conexão hidrofóbica, os resíduos hidrofóbicos interagem estavelmente a uma distância constante de forma que, assim como regiões realizando muitas $\mathrm{LdH}$, podem ser identificados por meio da integração dos píxeis presentes em uma matriz de contato.

O GROMACS fornece uma ferramenta para integrar todos os contatos automaticamente ao fazer a matriz de contatos, gerando um gráfico com o número de contatos relativos estabelecidos por cada resíduo de aminoácido. Lembrando que a integração refere-se à matriz entre todos os contatos, intra- e intermoleculares, como ilustrado na Figura 33, que ilustra apenas a parte intermolecular da matriz original. O resultado dessa ferramenta, comparando Dock1 e Dock 2, pode ser visto na Figura 34:

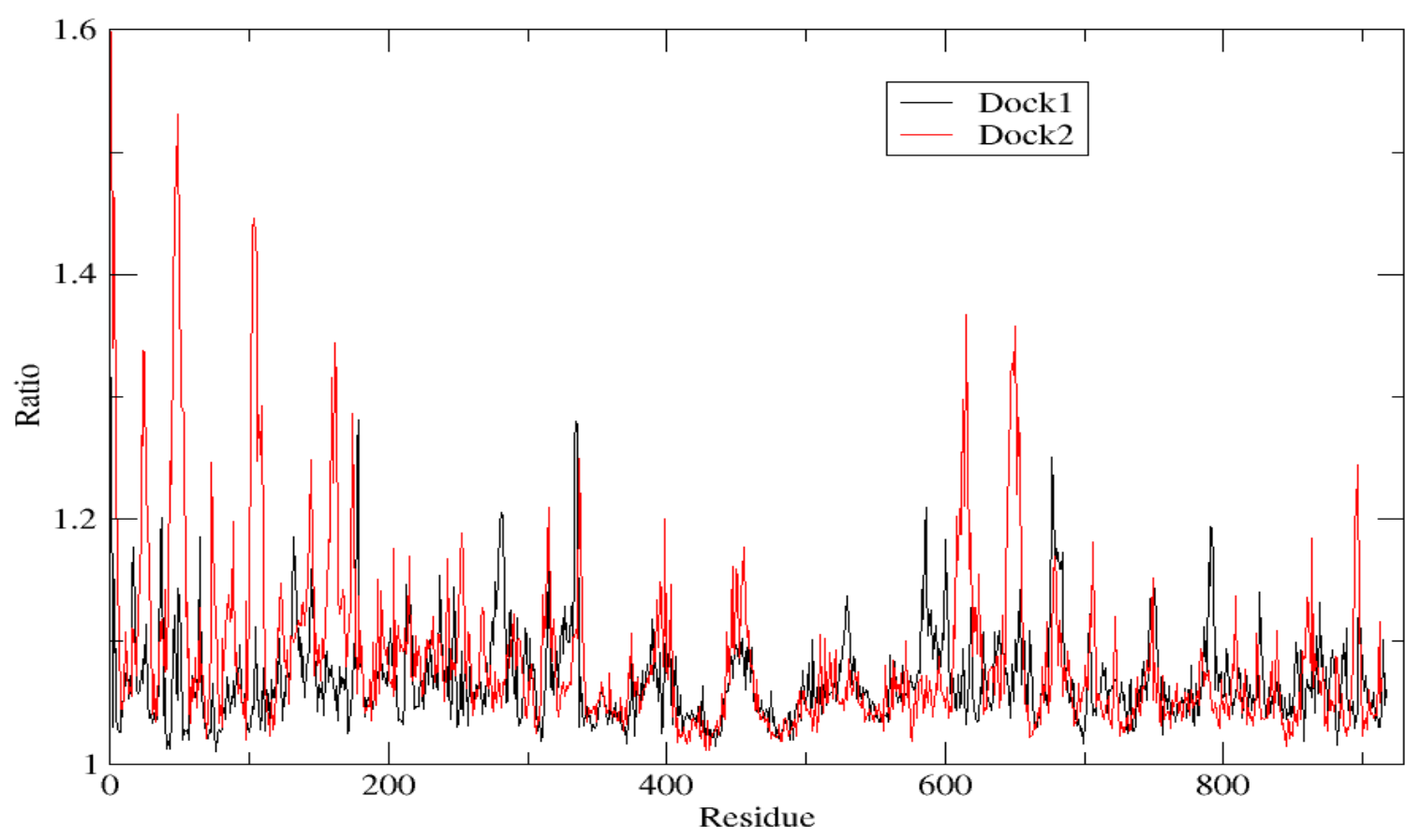

Figura 34: Aumento relativo de contatos feitos por cada aminoácido após 76 ns. Os primeiros 335 resíduos são referentes ao $B T-\mathrm{R}_{1}$ enquanto o restante é referente à toxina Cry1Ab. Esse gráfico indica quantas vezes mais contatos diferenciais foram feitos por um resíduo de aminoácido, durante a simulação, em relação ao seu estado inicial. 
A interpretação desse gráfico indica que, a partir da estrutura inicial do docking, os resíduos envolvidos em Dock2 fizeram mais novos contatos durante a simulação do que os resíduos de Dock1 (incluindo intra- e intermoleculares, com um peso maior para o último). Como é possível ver, essa integração não gera informações relativas às distâncias entre pares de resíduos, muito menos sobre quais regiões são contatos polares ou hidrofóbicos. A maneira escolhida para engajar essa questão foi extrair apenas a região contendo contatos intermoleculares da matriz original (Figura 33), e integrar separadamente cada região correspondendo às RULs usando a ferramenta "Plot Profile" do software para tratamento e análise de imagens, "ImageJ" (http://imagej.nih.gov/ij/). Para isso, os blocos de interação originais de BR- $\mathrm{R}_{1}$ e Cry1Ab (não as RULs) foram precisamente identificados nos eixos $\mathrm{X}$ e $\mathrm{Y}$, respectivamente, das matrizes de contatos intermoleculares contidas na Figura 33. Dessa maneira foi possível identificar a área de cada bloco que deve ser integrada. Como exemplo desse processo, foi ilustrada a identificação de áreas feita em Dock1 (Figura 35).

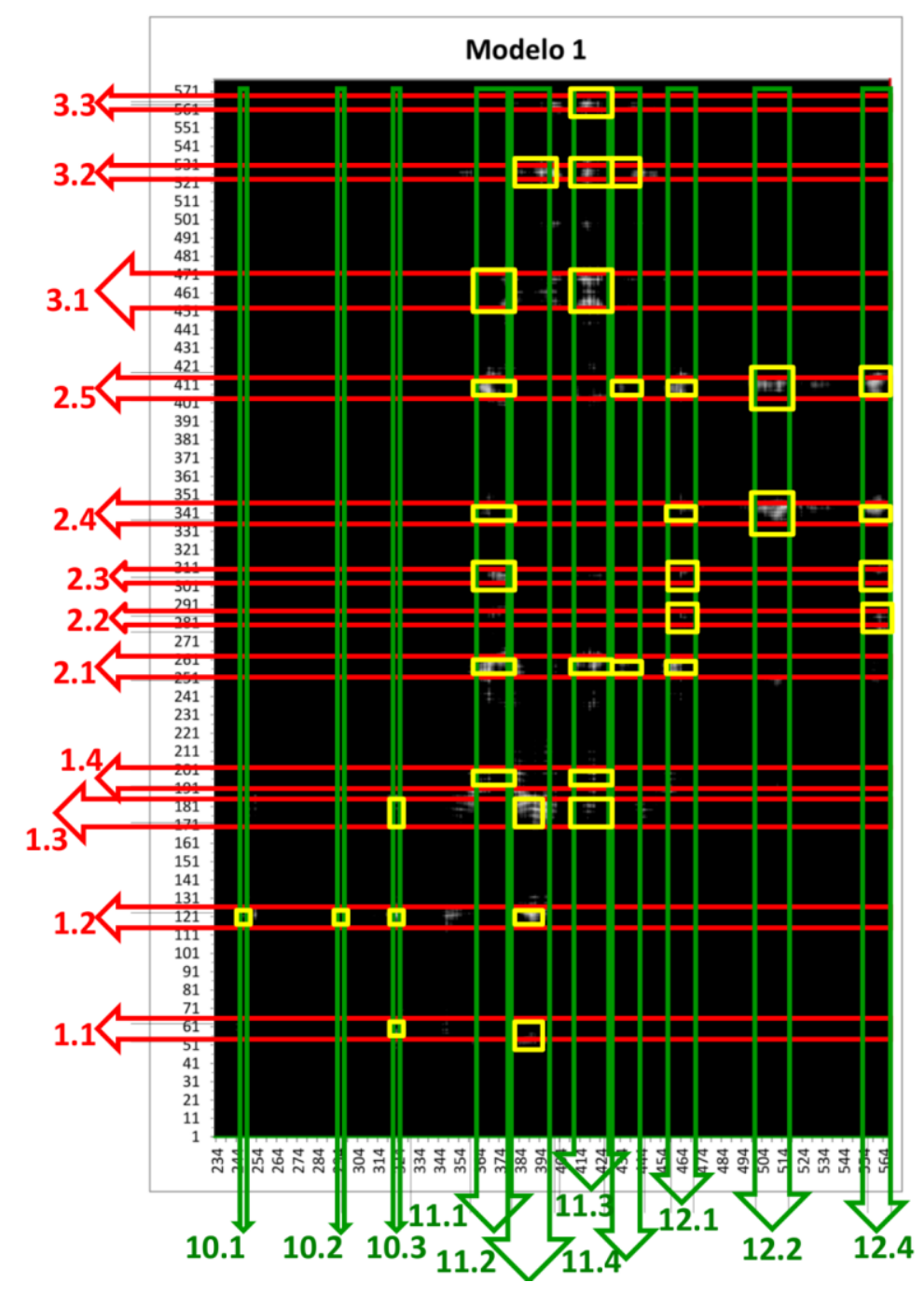

Figura 35: Identificação de áreas de integração referentes aos blocos de interação de cada proteína em Dock1. Em vermelho estão ilustradas as áreas referentes aos blocos de interação de Cry1 Ab e em verde os referentes ao receptor BT$R_{1}$. A figura é meramente ilustrativa e não reflete a área real usada na integração. Em amarelo estão ilustrados os contatos entre os blocos de interação de cada proteína, que simbolizam os contatos polares. 
Estabelecidas as áreas de integração, pode-se identificar os contatos hidrofóbicos como os pontos brancos que sobram depois da sobreposição das áreas verdes com áreas vermelhas, ou seja, excluindo-se as áreas amarelas da Figura 35. De fato, os contatos hidrofóbicos estarão representados, mas dois problemas surgem ao se analisar dessa maneira: (1) diferentemente dos blocos de interação, identificados pelos resíduos que participam de ligações de hidrogênio, não é possível identificar precisamente onde começam e terminam as regiões de contatos hidrofóbicos; (2) não é possível quantificar visualmente a intensidade de cada píxel (equivalente à média de distâncias) de diferentes regiões pois, além de pontos brancos, o que se procura são pontos brancos intensos medidos com precisão.

Estabelecidas as áreas, estas foram integradas com relação à Cry1 Ab, ou seja, o equivalente às áreas vermelhas da Figura 35. O motivo de não se fazer também a integração com relação ao BT-R $\mathrm{R}_{1}$ é que o objetivo do estudo é inferir quais regiões da toxina são responsáveis por determinar sua especificidade ao receptor. A partir dessa identificação, as regiões podem ser utilizadas em uma análise evolutiva visando entender como as toxinas 3D-Cry adquiriram toxicidade a tantas ordens de insetos e de maneira tão específica. Como essas regiões apresentam alto potencial eletrostático e estão próximas a sítios hidrofóbicos na interface de interação, é suficiente identificar, nos blocos de Cry1 Ab, as região não polares de BT- $\mathrm{R}_{1}$ que estão em contato $(\leq 10 \AA)$. Se essas regiões forem identificadas em um bloco, haverá indícios de que este bloco é capaz de interagir indiretamente sobre sítios hidrofóbicos.

A área integrada de cada bloco foi copiada individualmente e alinhada ao seu respectivo gráfico de integração, a fimm de comprovar a precisão do método. Além disso, os gráficos oriundos de blocos equivalentes em Dock1 e Dock2 (i.e. blocos pertencentes a uma mesma RUL, Tabela 9) foram alinhados lado a lado para comparar o perfil de ligação dessas regiões. Como a área integrada foi diferente para cada caso, os valores absolutos de tons de cinza gerados pela integração não são comparáveis entre si. Por isso, foi tomado o cuidado de se organizar todos os dados em gráficos idênticos, com $\mathrm{X}$ e Y do mesmo tamanho, podendo-se então fazer uma comparação diretamente visual entre os picos. Por fim, foram identificados precisamente, no eixo $\mathrm{X}$ de cada gráfico, os blocos de BT-R 1 que participam de LdH (polares). Dessa maneira foi possível fazer a busca por blocos de interação de Cry1 Ab que estão próximos de regiões hidrofóbicas de BT-R 1 (Figura 36, partes A, B e C). 
Dock1

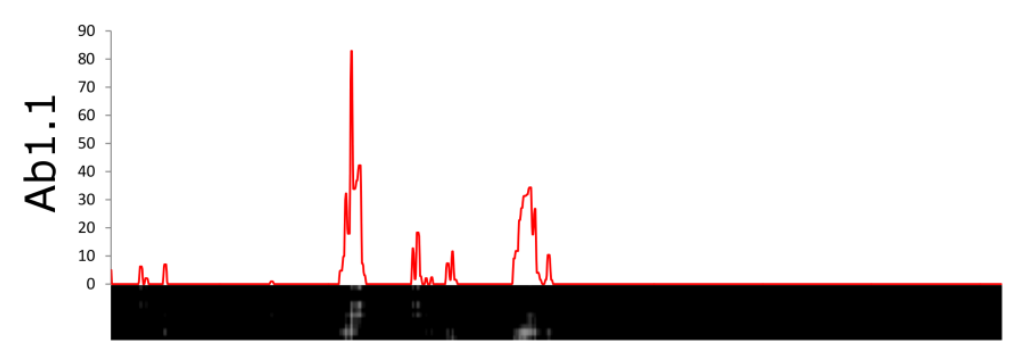

Dock2
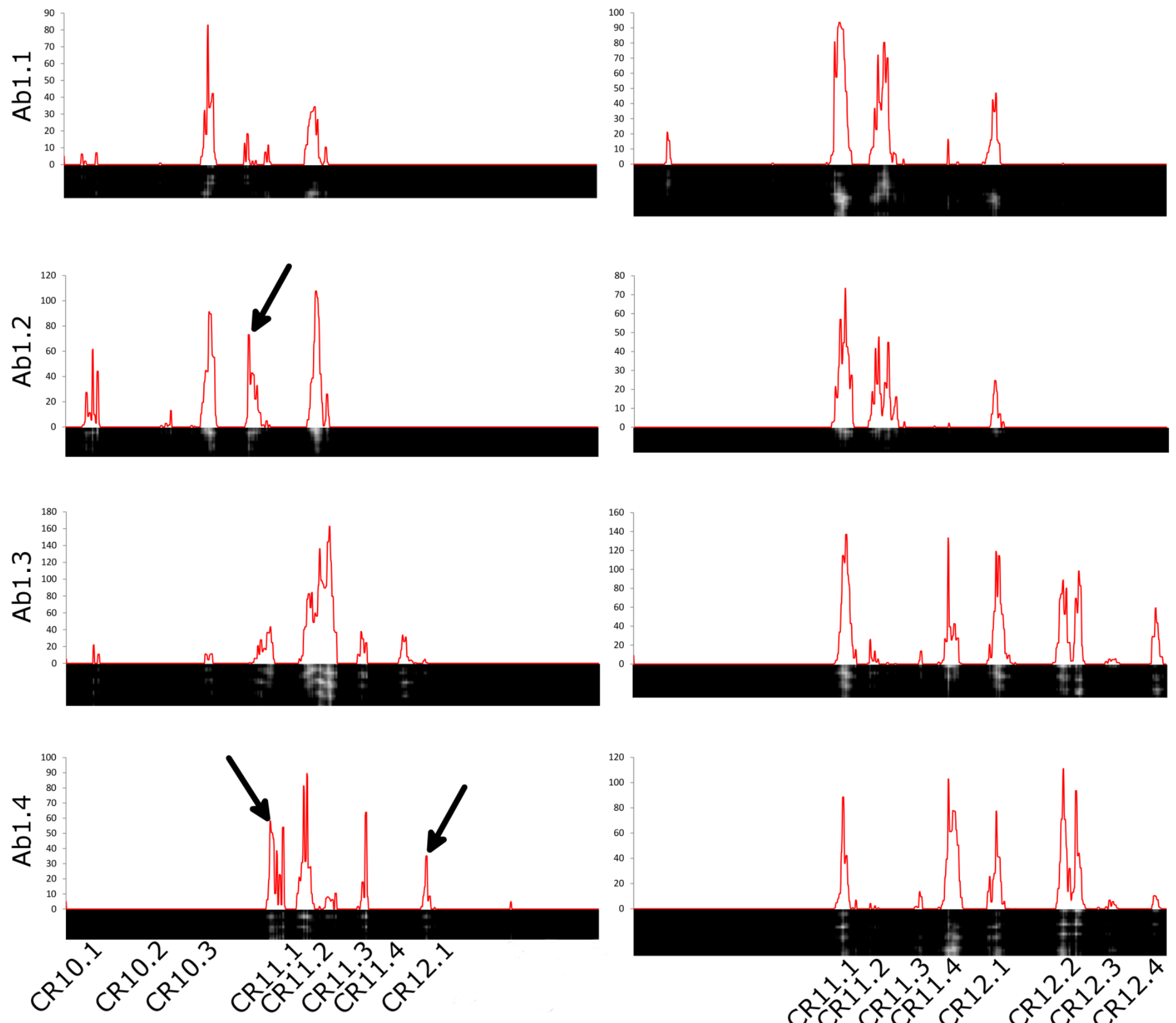

Figura 36(A): Integração da matriz de contatos em relação aos blocos de interação de Cry1Ab. As áreas integradas de cada bloco foram copiadas individualmente e alinhadas aos seus respectivos gráficos. Eixos X e Y apresentam tamanhos idênticos, o que permite a comparação proporcional dos valores absolutos de tons de cinza integrados. A legenda do eixo $\mathrm{X}$ tem precisão limitada e não reflete a precisão usada para diferenciar os blocos de interação de BT- $\mathrm{R}_{1}$. Setas indicam sítios hidrofóbicos. 
Dock1
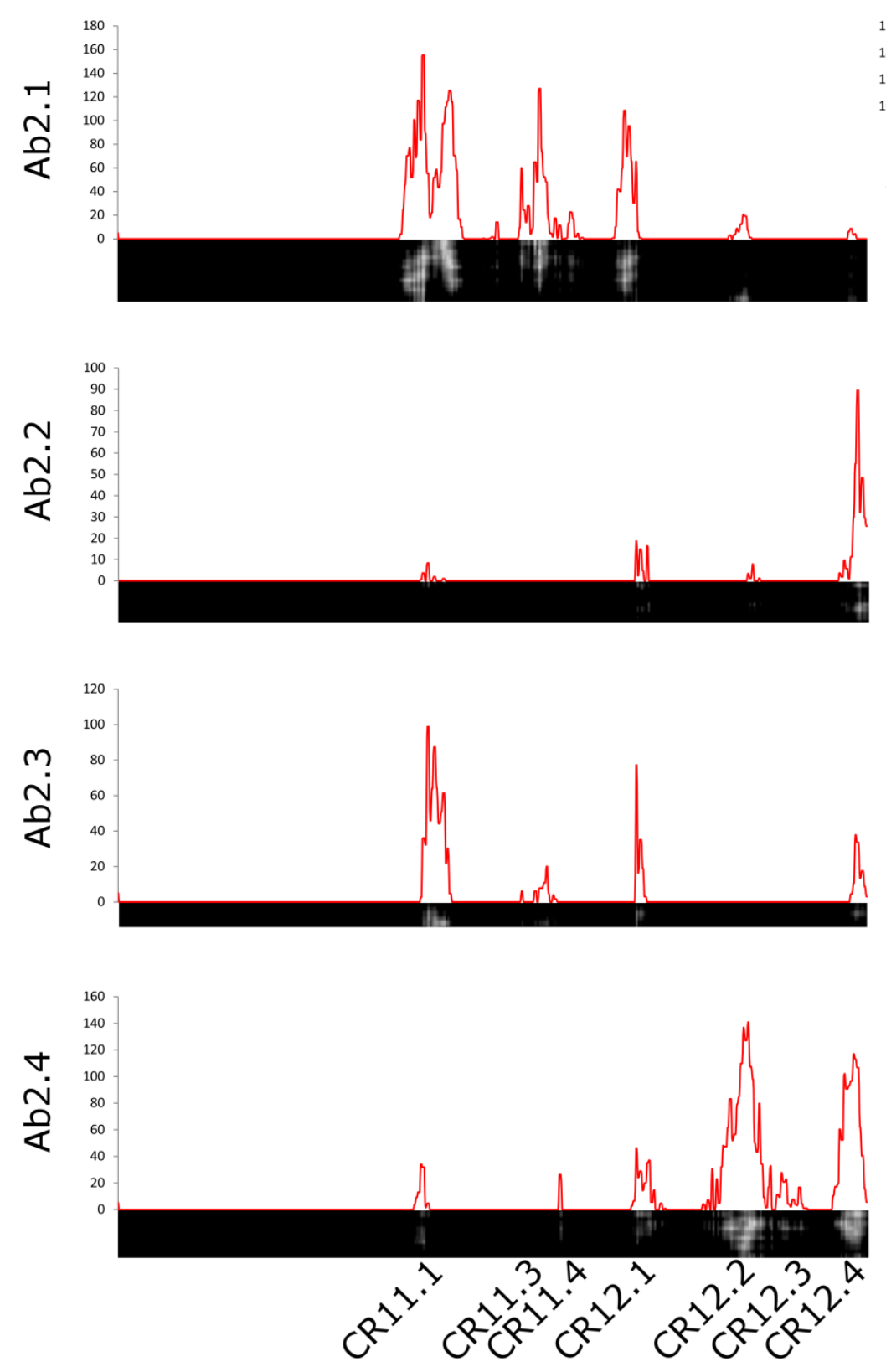

Dock2
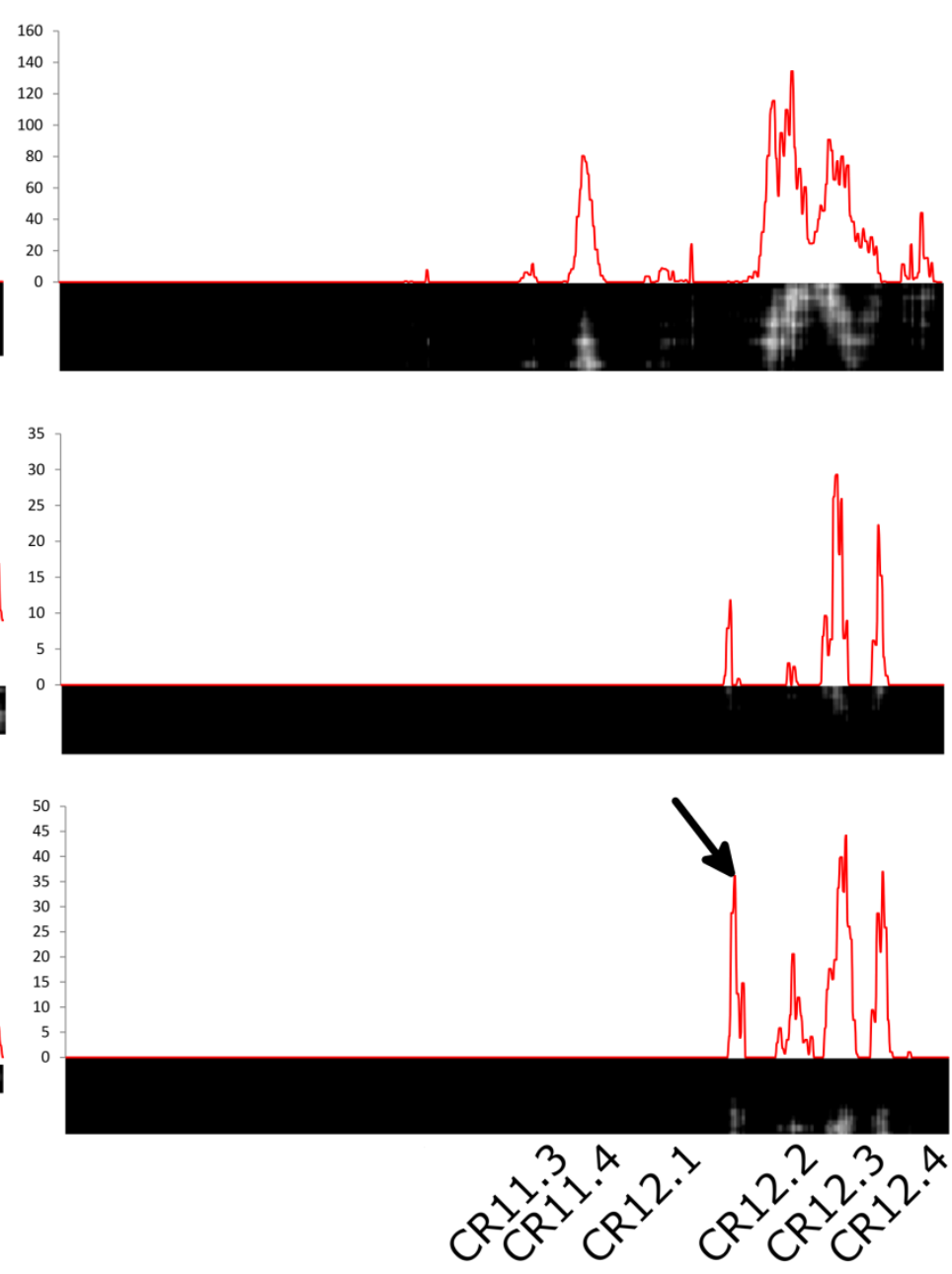

Figura 36(B): Integração da matriz de contatos em relação aos blocos de interação de Cry1Ab. As áreas integradas de cada bloco foram copiadas individualmente e alinhadas aos seus respectivos gráficos. Eixos $\mathrm{X}$ e Y apresentam tamanhos idênticos, o que permite a comparação proporcional dos valores absolutos de tons de cinza integrados. A legenda do eixo $\mathrm{X}$ tem precisão limitada e não reflete a precisão usada para diferenciar os blocos de interação de BT- $\mathrm{R}_{1}$. Setas indicam sítios hidrofóbicos. 


\section{Dock1}
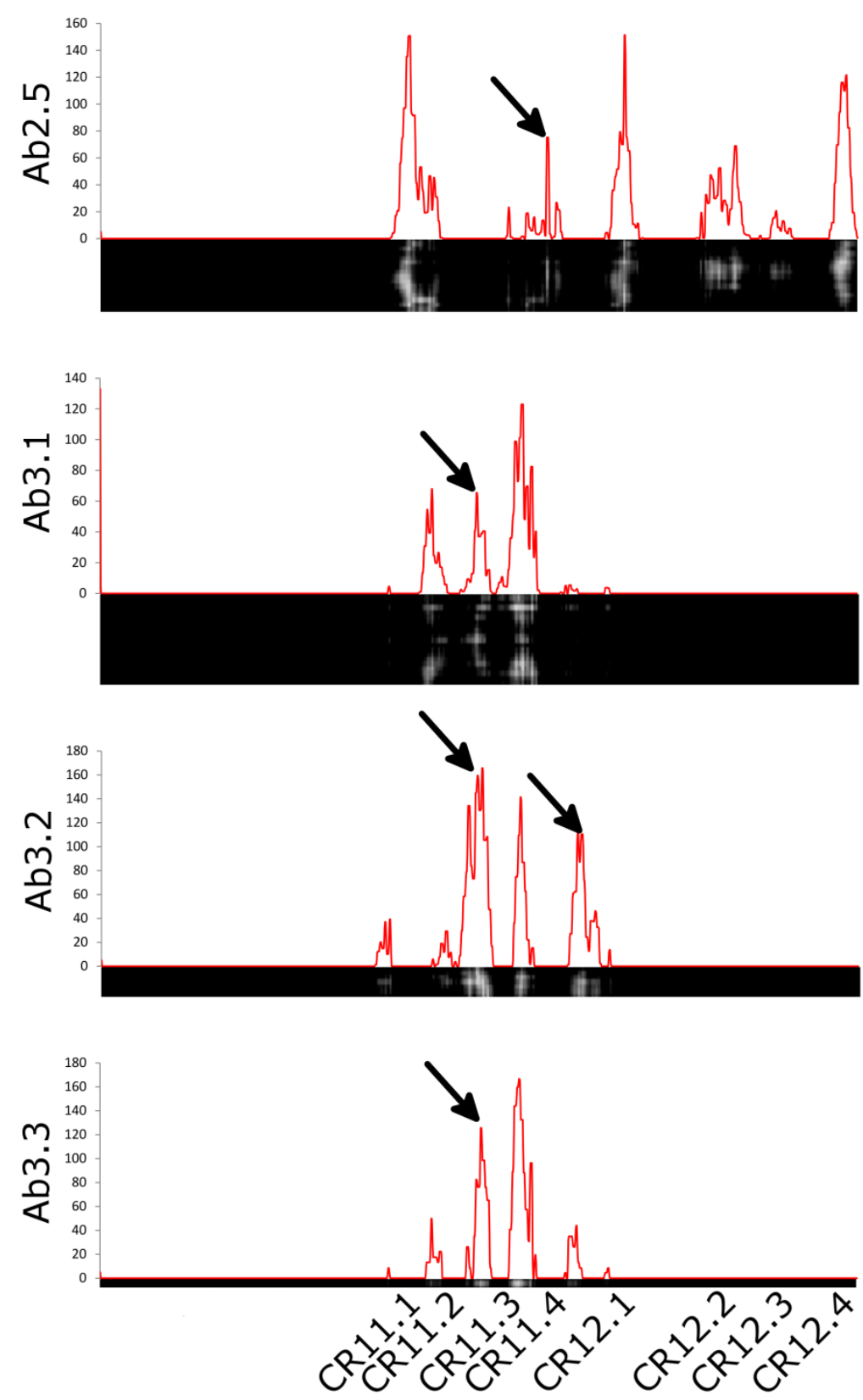

\section{Dock2}
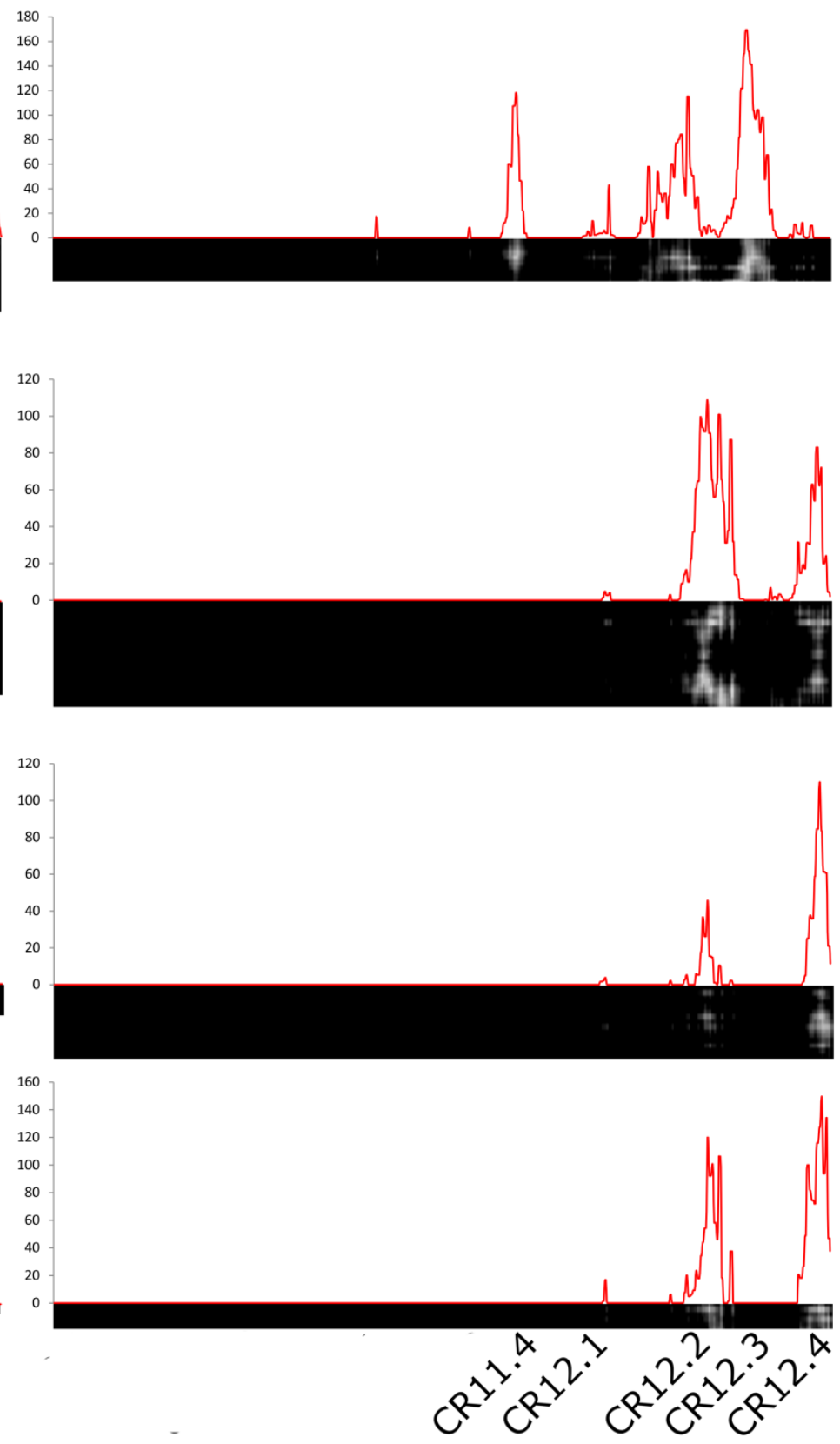

Figura 36(C): Integração da matriz de contatos em relação aos blocos de interação de Cry1Ab. As áreas integradas de cada bloco foram copiadas individualmente e alinhadas aos seus respectivos gráficos. Eixos X e Y apresentam tamanhos idênticos, o que permite a comparação proporcional dos valores absolutos de tons de cinza integrados. A legenda do eixo $\mathrm{X}$ tem precisão limitada e não reflete a precisão usada para diferenciar os blocos de interação de BT- $\mathrm{R}_{1}$. Setas indicam sítios hidrofóbicos. 
Sete blocos de interações de Cry1 Ab podem atuar indiretamente sobre regiões hidrofóbicas do receptor BT- $\mathrm{R}_{1}$. De fato, ao verificar na sequência do receptor que foi modelada, as regiões denotadas por setas na Figura 36 são todas caracterizadas pela presença de aminoácidos fortemente hidrofóbicos, como a região ${ }_{1286} \mathrm{IIDGN}_{1290}$, entre CR11.2 e CR11.3, que contém dois resíduos de isoleucinas (Figura 36C) e é completamente exposta ao solvente. Curiosamente, todas as regiões denotadas por setas possuem pelo menos um resíduo de isoleucina. Ao final, as regiões com potencial de induzir conexões hidrofóbicas na interface de interação foram identificadas como sendo Ab1.2, Ab1.4, Ab2.3, Ab2.5, Ab3.1, Ab3.2 e Ab3.3. Dessas, apenas Ab2.3 representa o modelo Dock2.

\subsubsection{Cálculos de potenciais elétricos e pontes salinas}

O passo seguinte foi identificar o potencial eletrostático dessas regiões. Para calcular o potencial eletrostático de uma região, primeiro somam-se todas as cargas, gerando uma densidade elétrica, e depois se integra essa soma para obter o campo elétrico dessa região. Por fim, uma nova integração do campo gera o potencial eletrostático. O potencial eletrostático pode ser interpretado como o cálculo de todas as energias potenciais eletrostáticas a uma determinada distância da molécula. As energias potenciais eletrostáticas, por sua vez, são uma medida da força de cargas, núcleos e elétrons dispersos ao redor da molécula. Assim, o potencial eletrostático mede a distribuição de cargas espalhadas por uma região.

Para o cálculo de potenciais eletrostáticos foram usadas as RULs, pois permitem comparar uma mesma região em Dock1 e Dock2, e obter informações suficientes sobre os blocos de interação. Os potencias estão apresentados na Tabela 10.

Utilizando o método descrito anteriormente, foi possível analisar individualmente todas as pontes salinas (intra e intermoleculares) em função do tempo da simulação. Entre as interações intermoleculares de curta distância, a ponte salina é a de maior energia, seguida das ligações de hidrogênio e dispersões de London. Portanto, pontes salinas duradoura indicam a estabilidade de uma região de interação. As pontes salinas intermoleculares realizadas em Dock1 e Dock2 foram analisadas em relação aos resíduos de Cry1 Ab e selecionadas seguindo o critério de que pontes salinas duradouras, após estabelecerem contato $\leq 4 \AA$, permanecem a essa distância até o final da simulação. 


\begin{tabular}{|c|c|c|c|c|c|c|}
\hline \multicolumn{7}{|c|}{ Cry1 Ab } \\
\hline \multirow[b]{2}{*}{ RUL } & \multicolumn{3}{|c|}{ Dock1 } & \multicolumn{3}{|c|}{ Dock2 } \\
\hline & $\begin{array}{c}\text { Potencial } \\
\text { Eletrostático } \\
\text { (Volts) }\end{array}$ & $\begin{array}{l}\text { Resíduos } \\
\text { formando } \\
\text { pontes } \\
\text { salinas } \\
\end{array}$ & $\begin{array}{c}\text { Resíduos } \\
\text { participando } \\
\text { em LdH } \\
\text { persistentes }\end{array}$ & $\begin{array}{c}\text { Potencial } \\
\text { Eletrostático } \\
\text { (Volts) }\end{array}$ & $\begin{array}{c}\text { Resíduos } \\
\text { formando } \\
\text { pontes } \\
\text { salinas } \\
\end{array}$ & $\begin{array}{l}\text { Resíduos } \\
\text { participando } \\
\text { em LdH } \\
\text { persistentes }\end{array}$ \\
\hline Ab1.1 & 0.896694 & 3 & - & 1.1386 & 3 & 4 \\
\hline $\mathrm{Ab} 1.2$ & -0.011749 & 0 & 3 & -0.0350288 & 0 & 3 \\
\hline Ab1.3 & -0.0663191 & 3 & 6 & -0.180324 & 1 & 4 \\
\hline Ab1.4 & -0.685776 & 1 & - & -0.671359 & 5 & 3 \\
\hline $\mathrm{Ab} 2.1$ & -0.521392 & 3 & 6 & -0.4277 & 2 & 6 \\
\hline $\mathrm{Ab} 2.2$ & 0.59271 & 2 & - & -0.248533 & 1 & 0 \\
\hline $\mathrm{Ab} 2.3$ & -0.473807 & 0 & - & -0.570484 & 1 & 0 \\
\hline Ab2.4 & -0.509048 & 1 & 2 & -0.332048 & - & - \\
\hline$A b 2.5$ & -0.849556 & 2 & 4 & -0.643223 & 3 & 6 \\
\hline Ab3.1 & -0.748967 & 1 & 2 & -0.843978 & 1 & 5 \\
\hline Ab3.2 & -0.553231 & 0 & 2 & -0.79445 & 1 & 1 \\
\hline Ab3.3 & 0.368967 & 1 & 1 & 0.598367 & 1 & 3 \\
\hline \multicolumn{7}{|c|}{ BT-R1 } \\
\hline \multirow[b]{2}{*}{$\begin{array}{l}\text { Binding } \\
\text { Epitope }\end{array}$} & \multicolumn{3}{|c|}{ Dock1 } & \multicolumn{3}{|c|}{ Dock2 } \\
\hline & $\begin{array}{c}\text { Potencial } \\
\text { Eletrostático } \\
\text { (Volts) }\end{array}$ & $\begin{array}{c}\text { Resíduos } \\
\text { formando } \\
\text { pontes } \\
\text { salinas }\end{array}$ & $\begin{array}{c}\text { Resíduos } \\
\text { participando } \\
\text { em LdH } \\
\text { persistentes }\end{array}$ & $\begin{array}{c}\text { Potencial } \\
\text { Eletrostático } \\
\text { (Volts) }\end{array}$ & $\begin{array}{c}\text { Resíduos } \\
\text { formando } \\
\text { pontes } \\
\text { salinas }\end{array}$ & \begin{tabular}{|c} 
Resíduos \\
participando \\
em LdH \\
persistentes
\end{tabular} \\
\hline CR-10.1 & 0.219628 & 0 & 0 & 0.196983 & 0 & 0 \\
\hline CR-10.2 & 3.60153 & 2 & 0 & 6.85954 & 2 & 0 \\
\hline CR-10.3 & 0.489269 & 3 & 2 & 1.43367 & 1 & 0 \\
\hline CR-11.1 & 0.832953 & 4 & 7 & 1.3603 & 2 & 6 \\
\hline CR-11.2 & 1.12163 & 3 & 13 & 2.03627 & 0 & 4 \\
\hline CR-11.3 & -0.535707 & 2 & 0 & -0.95754 & 1 & 0 \\
\hline CR-11.4 & -0.0330054 & 0 & 1 & -0.128658 & 1 & 4 \\
\hline CR-12.1 & -0.152157 & 0 & 1 & -0.122961 & 1 & 0 \\
\hline CR-12.2 & 1.89072 & 3 & 5 & 2.43783 & 3 & 12 \\
\hline CR-12.2/12.3 & 0.757882 & - & - & 0.895326 & 3 & 10 \\
\hline CR-12.3 & -0.365963 & - & - & -0.362206 & 0 & 4 \\
\hline CR-12.4 & 0.825676 & 2 & 5 & 1.77368 & 1 & 13 \\
\hline
\end{tabular}

Tabela 10: Potencial eletrostático das RULs e resumo dos resíduos de aminoácidos participando em pontes salinas e em ligações de hidrogênio persistentes. Regiões com potencial eletrostático positivo estão marcadas em tons de azul para diferenciar grandes potenciais (escuro) e potenciais moderados (claros). O mesmo foi feito para potenciais negativos em tons de vermelho. A tabela também mostra a contribuição, em número de resíduos participantes, de cada RUL para pontes salinas e LdH persistentes. 
Um total de 8 e 9 pontes salinas permaneceram ligadas estavelmente a uma distância $\leq 4 \AA$ em Dock1 e Dock2, respectivamente. Em Dock1, essas pontes se encontram em Ab1.3, Ab2.1, Ab2.5 e Ab3.1, e em Dock2 estão distribuídas entre Ab1.1, Ab1.4, Ab2.2, Ab2.3, Ab3.1 e Ab3.2. Esse resultado permite inferir que a região Ab3.1 tem um papel importante na estabilização da toxina ao receptor.

\subsubsection{Ensaio in vitro utilizando ressonância plasmônica de superfície (SPR)}

Em uma tentativa de validar as interações observadas durante a dinâmica molecular, foram sintetizados alguns peptídeos correspondendo às RUL para utilização em ensaios de ligação por meio de SPR. Os ensaios foram feitos utilizando o equipamento Biacore X100, que monitora a interação entre duas ou mais moléculas em tempo real. Não existiam na literatura, até o momento dos ensaios, relatos sobre a interação entre peptídeos usando SPR, de maneira que os ensaios não tem uma referência de qualidade. O peptídeo correspondendo à RUL Ab2.5 (loop 3 do D-II) foi escolhido como analito devido à sua vasta descrição na literatura como uma região de reconhecimento ao receptor. Os primeiros ensaios utilizaram como ligante o peptídeo correspondendo à RUL de CR11.1 e como controles às RULs correspondendo à CR12.1, CR10.3 e Ab2.1. No modelo Dock1, CR11.1 é um dos blocos preditos a ligarse com Ab2.5 (Figura 36C). Já os outros peptídeos foram usados para avaliar interações inespecíficas, sendo que CR12.1 é predito para se ligar à Ab2.5 com uma afinidade mais baixa que CR11.1 e mais alta que os outros dois controles. O primeiro ensaio foi feito usando HBS (HEPES buffered saline) $\mathrm{pH7,4}$, conforme os experimentos padrão do Biacore, utilizando uma concentração alta de CR11.1 (400 $\mu \mathrm{M})$ (Figura 37). 


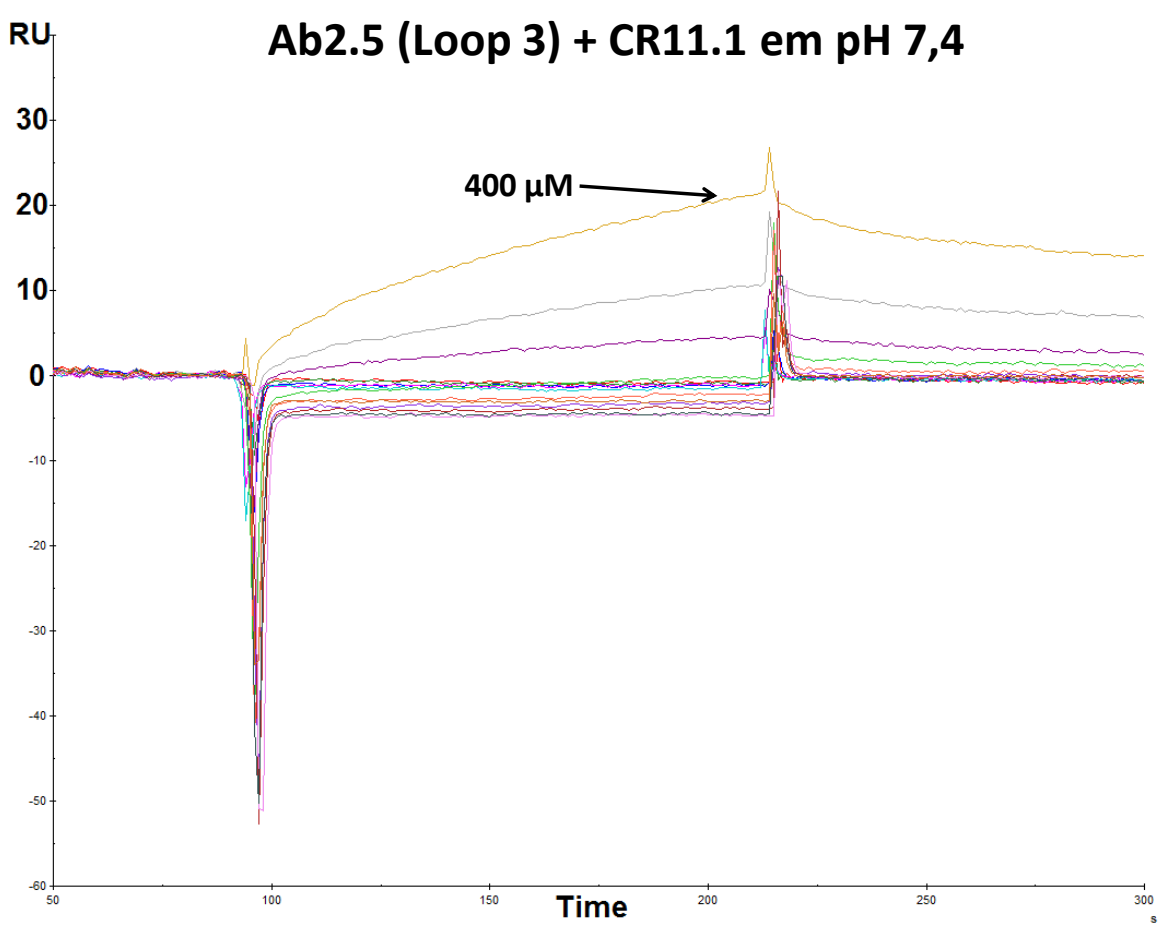

Figura 37: Ensaio de SPR para a interação entre Ab2.5 e CR11.1 em pH 7,4.

O ensaio em pH 7,4 resultou em uma curva típica de interação específica entre os dois peptídeos, com uma dissociação lenta. No entanto, a concentração de ligante (CR11.1) utilizada foi muito elevada e o sinal muito baixo. Ensaios comuns de SPR geralmente utilizam no máximo $2 \mu \mathrm{M}$ de ligante. Para tentar otimizar a interação, o ensaio foi repetido em $\mathrm{pH}$ 9,0 para simular o ambiente alcalino encontrado no intestino de Manduca sexta, onde a ligação de Cry $1 \mathrm{Ab}$ com BT- $\mathrm{R}_{1}$ ocorre in vivo. Esse ensaio foi repetido três vezes e foi constatado saturação da ligação em concentrações de ligante próximas a $25 \mu \mathrm{M}$, de maneira que nos ensaios seguintes a concentração máxima de 50 $\mu \mathrm{M}$ foi mantida para exemplificar esse fenômeno (Figura 38).

Este experimento reproduziu o resultado do ensaio em $\mathrm{pH} 7,4$ utilizando 266 vezes menos peptídeo, mas acarretou em uma dissociação rápida do ligante, indicando baixa afinidade na interação. Uma vez estabelecido o pH 9,0 como ótimo para a ligação, foram feitos testes com concentrações elevadas $(330 \mu \mathrm{M})$ dos peptídeos controle (Figura 39). Os resultados mostraram baixa afinidade, o que indicou a existência de interações inespecíficas com Ab2.5. O experimento foi então repetido em um novo chip contendo Ab2.5 imobilizado, o ligante CR11.1 e os três controles negativos (Figura 40). 


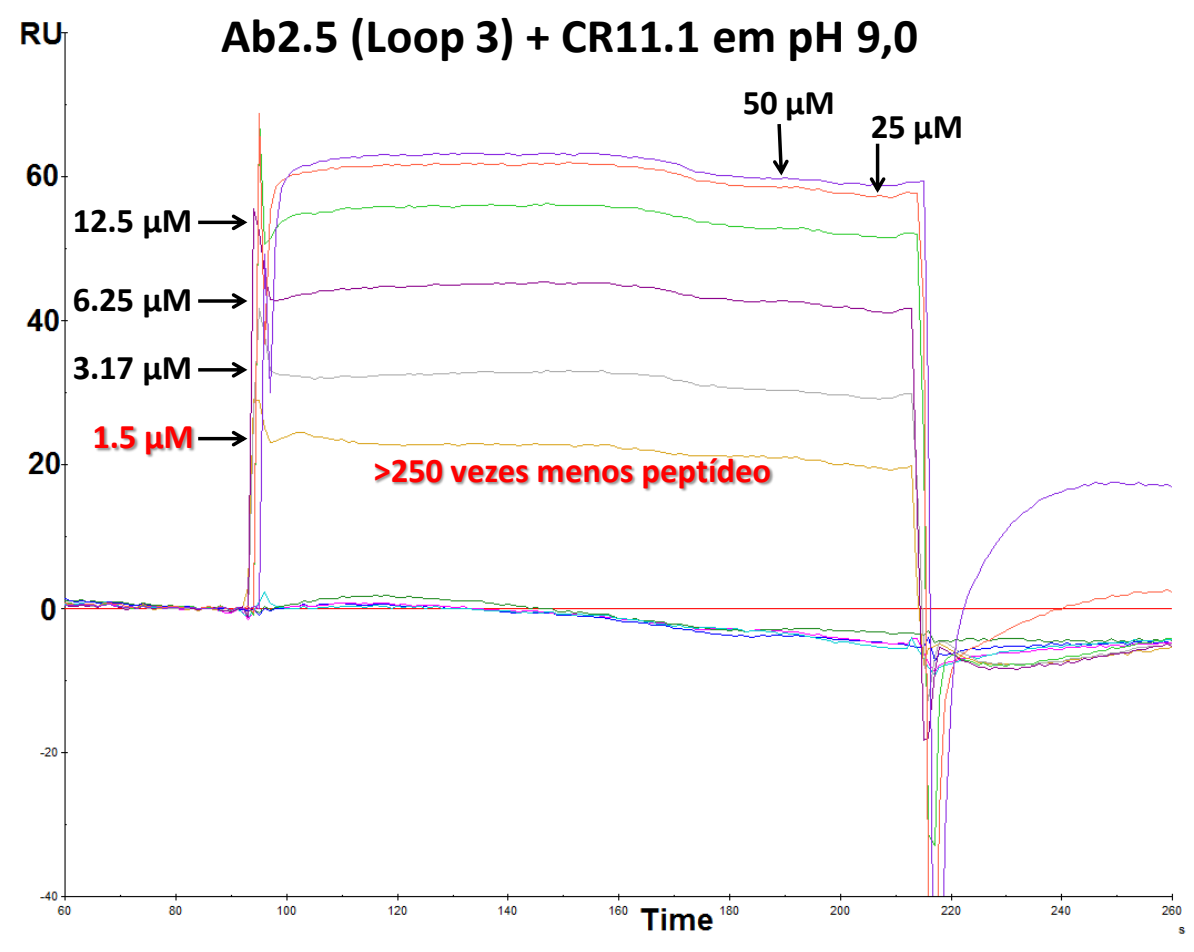

Figura 38: Ensaio de SPR para a interação entre Ab2.5 e CR11.1 em Tris HCl pH 9.0. A concentração de $1,5 \mu \mathrm{M}$ foi destacada para comparar o ensaio feito em $\mathrm{pH} 7,4$, uma vez que essa concentração produziu uma resposta de mesma intensidade.

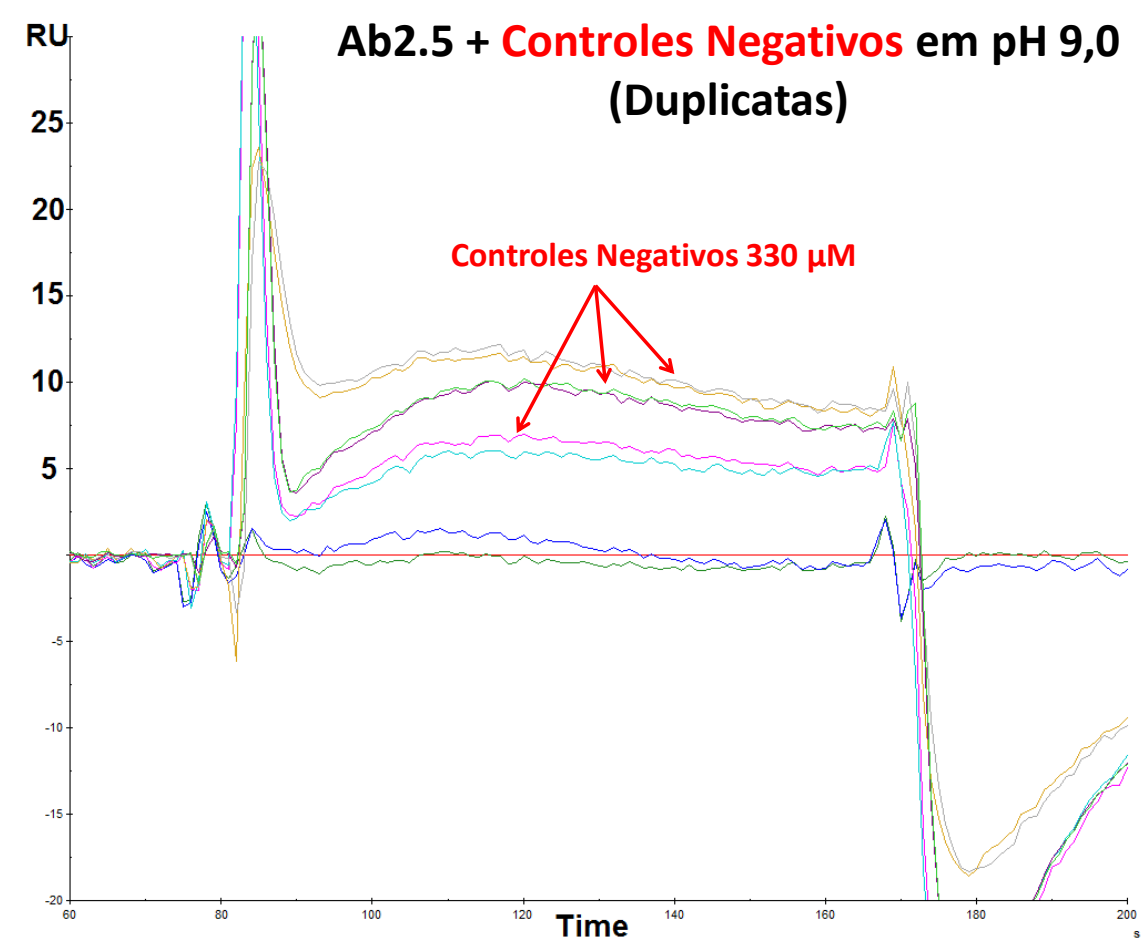

Figura 39: Ensaio de SPR para a interação entre Ab2.5 e os controles CR12.1, CR10.3 e Ab2.1 em Tris HCl pH 9,0. Foram utilizadas concentrações altas dos controles e foi observada a presença de interação inespecífica. 


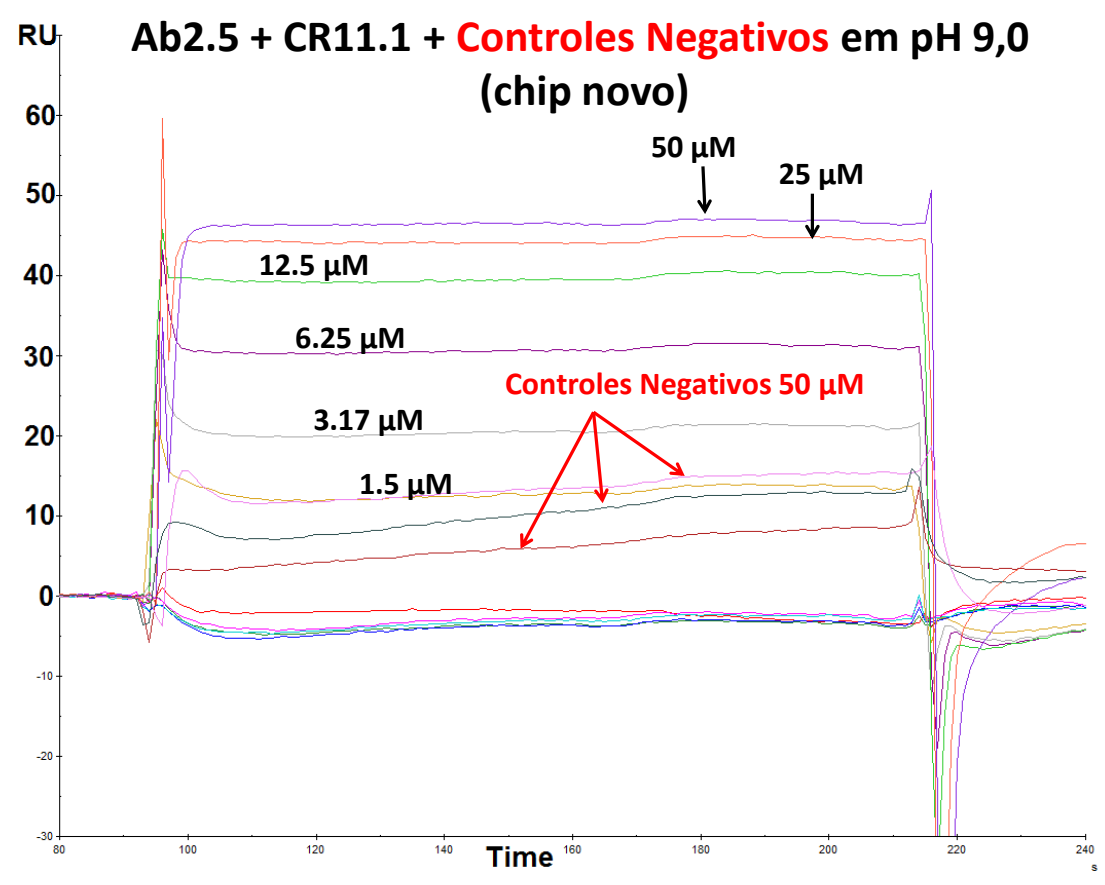

Figura 40: Ensaio de SPR para a interação entre Ab2.5 e o ligante CR11.1, acrescido dos controles CR12.1, CR10.3 e Ab2.1 (Tris HCl pH 9,0).

Nestes ensaios, os resultados obtidos foram os mesmos observados anteriormente, uma vez que foram imobilizadas quantidades similares de Ab2.5 no novo chip. Em seguida adicionou-se $50 \mathrm{mM}$ de $\mathrm{NaCl}$ para avaliar a influência da adição de íons na interação entre os peptídeos (Figura 41). Neste ensaio a interação foi completamente abolida entre todos os peptídeos, sugerindo que estes se ligam principalmente por interações eletrostáticas.

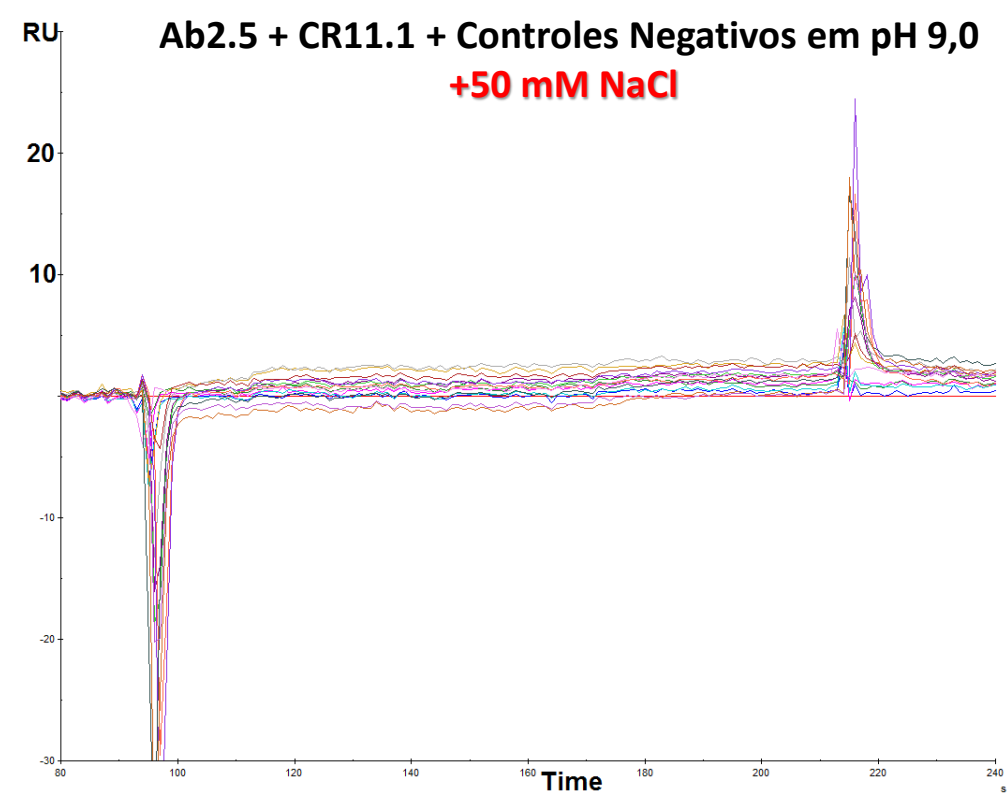

Figura 41: Repetição do ensaio de SPR na presença de NaCl 50 mM. 
Por fim, o experimento foi repetido em duplicatas utilizando-se concentrações baixas do ligante e controles. O sinal da resposta foi de baixa intensidade, mas apresentou um perfil compatível com a ocorrência de interação (Figura 42).

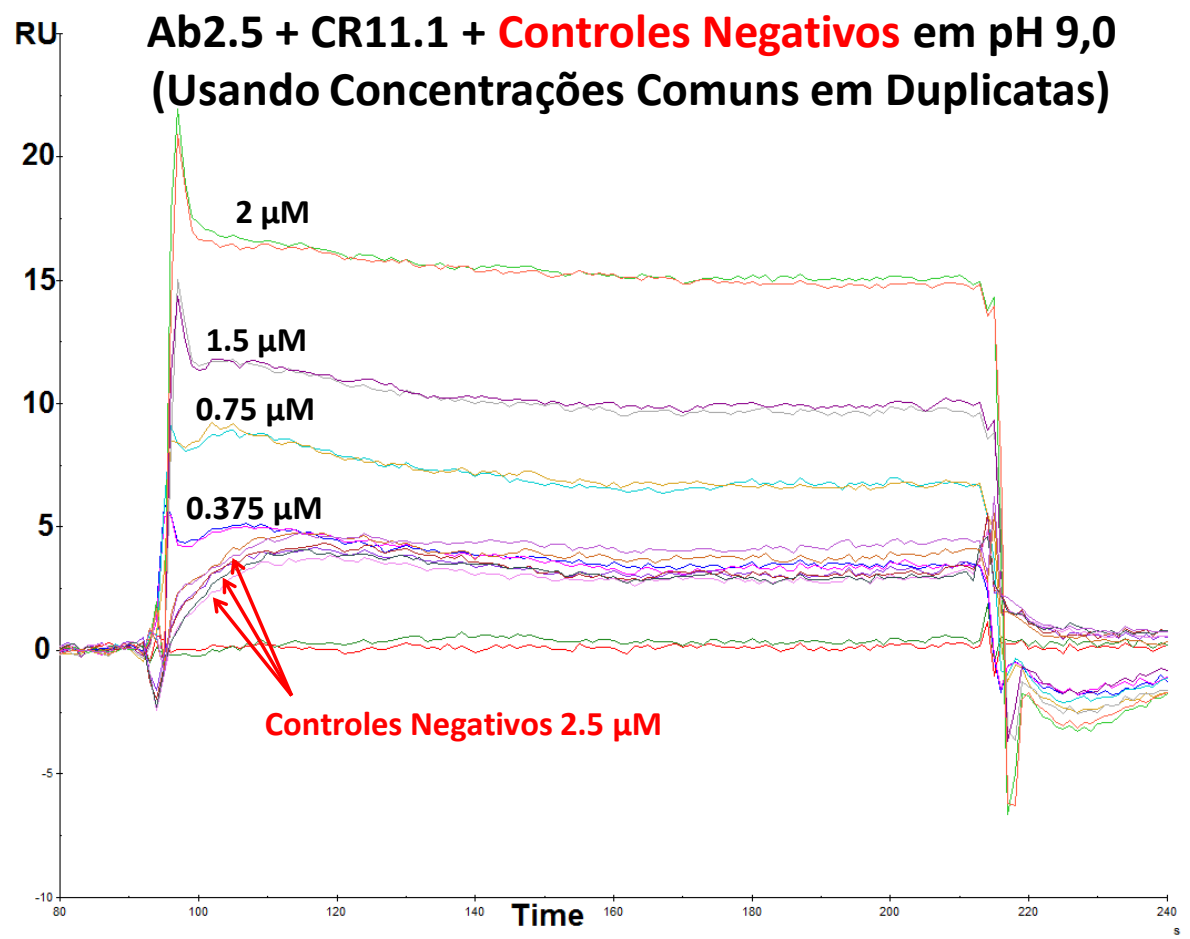

Figura 42: Ensaio de SPR para a interação entre Ab2.5 e baixas concentrações do ligante CR11.1 e controles CR12.1, CR10.3 e Ab2.1 (Tris HCl pH 9,0).

Em geral, os ensaios de SPR utilizando peptídeos são promissores, e algumas estratégias podem ser utilizadas para aprimorar os resultados. Por exemplo, o peptídeo ligante (CR11.1) corresponde à sequência completa dessa RUL. No entanto, a região que interage unicamente com Ab2.5 é cerca de metade desse tamanho (o restante interage com outros blocos de Cry1 Ab). Outro fator que dificultou bastante os ensaios foi a insolubilidade do peptídeo CR11.1, que pode ter influenciado também na variação de intensidade dos sinais, uma vez que a insolubilidade advém das interações intramoleculares deste peptídeo. Além disso, há a possibilidade da metade não ligante do peptídeo atrapalhar a interação da metade ligante. De qualquer forma, duas considerações devem ser feitas em relação a esses ensaios. Primeiramente, o fato de ter havido saturação em repetidos experimentos é um bom indicativo de se tratar de uma ligação específica ao invés de inespecífica. Por outro lado, foi imobilizado uma grande quantidade do peptídeo Ab2.5 ao chip, e como a ligação do ligante ao analito gera uma 
resposta proporcional à massa dessas moléculas, esperava-se uma resposta muito maior, já que houve saturação. O motivo disso ainda é especulativo.

\subsection{Conclusão}

O conjunto de dados gerados por RMSD (Figura 30), LdH, pontes salinas, potencial eletrostático e matriz de contatos (Figura 36) indicam que Ab1.3, Ab2.1, Ab2.5 e Ab3.1, em Cry1Ab, e CR10.3, CR11.1, CR11.2, CR12.2 e CR12.4, em BT-R 1 , são as regiões que melhor descrevem a ligação da toxina ao receptor caderina em Dock1 (Tabela 10 e Tabela 11).

\begin{tabular}{|c|c|c|c|c|c|c|c|c|c|c|c|c|}
\hline & $\begin{array}{c}\text { CR-10.1 } \\
(1126-1139) \\
\end{array}$ & \begin{tabular}{|c|} 
CR-10.2 \\
$(1159-1177)$ \\
\end{tabular} & \begin{tabular}{|c|} 
CR-10.3 \\
$(1203-1219)$ \\
\end{tabular} & $\begin{array}{c}\text { CR-11.1 } \\
\text { (1241-1262) } \\
\end{array}$ & \begin{tabular}{|c|} 
CR-11.2 \\
$(1263-1285)$ \\
\end{tabular} & $\begin{array}{c}\text { CR-11.3 } \\
\text { (1291-1307) } \\
\end{array}$ & $\begin{array}{c}\text { CR-11.4 } \\
(1312-1327) \\
\end{array}$ & $\begin{array}{c}\text { CR-12.1 } \\
(1340-1351) \\
\end{array}$ & \begin{tabular}{|c|} 
CR-12.2 \\
(1381-1403) \\
\end{tabular} & \begin{tabular}{|c|} 
CR-12.2/12.3 \\
$(1393-1415)$ \\
\end{tabular} & $\begin{array}{c}\text { CR-12.3 } \\
(1404-1425) \\
\end{array}$ & \begin{tabular}{|c|c} 
CR-12.4 \\
$(1437-1450)$ \\
\end{tabular} \\
\hline $\begin{array}{c}\text { Ab1.1 } \\
(81-95)\end{array}$ & $1 / 2$ & 1 & 1 & 2 & $1 / 2$ & & & & & & & \\
\hline $\begin{array}{c}\text { Ab1.2 } \\
(146-154)\end{array}$ & $1 / 2$ & & 1 & 2 & $1 / 2$ & & & & & & & \\
\hline $\begin{array}{c}\text { Ab1.3 } \\
(204-219)\end{array}$ & & & 1 & $1 / 2$ & 1 & 1 & 2 & 2 & 2 & & & 2 \\
\hline $\begin{array}{c}\text { Ab1.4 } \\
(220-233) \\
\end{array}$ & & & & 2 & & 1 & 2 & 2 & $1 / 2$ & & & \\
\hline $\begin{array}{c}\text { Ab2.1 } \\
(279-295) \\
\end{array}$ & & & & 1 & 1 & $1 / 2$ & 2 & 1 & $1 / 2$ & 2 & 2 & \\
\hline $\begin{array}{c}\text { Ab2.2 } \\
(308-320)\end{array}$ & & 2 & 2 & 1 & & & & 1 & 1 & & 2 & 1 \\
\hline $\begin{array}{c}\text { Ab2.3 } \\
(337-350)\end{array}$ & & 2 & 2 & 1 & & & & & & & 2 & 1 \\
\hline $\begin{array}{c}\text { Ab2.4 } \\
(369-379)\end{array}$ & & & & & & & & 1 & 1 & & & 1 \\
\hline $\begin{array}{c}\text { Ab2.5 } \\
(434-449) \\
\end{array}$ & & & & 1 & & & $1 / 2$ & 1 & $1 / 2$ & 2 & 2 & 1 \\
\hline $\begin{array}{c}\text { Ab3.1 } \\
(483-504)\end{array}$ & & & & 1 & 1 & 1 & & & 2 & 2 & 2 & 2 \\
\hline $\begin{array}{c}\text { Ab3.2 } \\
(552-567)\end{array}$ & & 2 & & & 1 & & 1 & & 2 & & & 2 \\
\hline $\begin{array}{c}\text { Ab3.3 } \\
(593-598) \\
\end{array}$ & & & & & 1 & 1 & 1 & & 2 & & & 2 \\
\hline
\end{tabular}

Tabela 11: Matriz das interações entre todas as regiões universais de ligação. As combinações entre RULs que interagem estão preenchidas em amarelo. $\mathrm{O}$ número contido em cada célula representa o modelo no qual ocorre a interação ( 1 = Dock1, 2 = Dock2). Células destacadas representam combinações entre RULs previstas como responsáveis pela interação específica da toxina ao receptor. As células destacadas com contorno roxo são exclusivas ao modelo Dock1; com contorno azul, exclusivas ao modelo Dock2; e com contorno preto, comuns a ambos os modelos.

O bloco de interação Ab1.3 apresenta forte ligação ao bloco CR11.2, como pode ser visto pro meio do número elevado de resíduos envolvidos em pontes salinas (3) e LdH persistentes (6), pelas medidas de RMSD (onde CR11.2 é estável) e pela integração da matriz de contatos (Figura 30 e Figura 36A). Curiosamente, o potencial eletrostático de Ab1.3 é próximo de zero. Essa região compreende à hélice $\alpha 6$ do domínio I, que tem a função de inserção na membrana das células intestinais do inseto. Possivelmente, a manutenção de um potencial eletrostático próximo de zero tem 
implicações para a interação com a camada bilipídica. Além disso, a forte interação dessa região com BT- $\mathrm{R}_{1}$ pode ser capaz de induzir uma mudança conformacional que permita a clivagem da hélice $\alpha 1$.

Os blocos Ab2.5 e Ab3.1 apresentam os dois maiores potenciais eletrostáticos dos blocos de interação de Cry1Ab (Tabela 10). O bloco Ab3.um é o principal atuante na interação com o bloco CR11.três e é o provável responsável pela estabilidade dessa região, como pode ser visto por RMSD (Figura 30). Notavelmente, a ligação de hidrogênio mais persistente (ARG501-ASP1298) está presente nessa interface de interação (Tabela 8). Nos gráfico de pontes salinas (dados não mostrados), os resíduos que participam dessa $\mathrm{LdH}$ formam a ponte de salina mais forte observada, que permanece interagindo a uma distância média de 3,5 ̊ durante toda a simulação. A integração da matriz de contatos mostrou que as interações de Ab3.um com CR11.um e CR11.três podem atuar sobre o sítio hidrofóbico ${ }_{1286} \mathrm{IIDGN}_{1290}$ (Figura 36C).

O bloco Ab2.um interage com o bloco CR11.um principalmente por meio de LdH, como pode ser visto na integração da matriz de contatos. Notavelmente, Ab2.cinco corresponde ao loop três do domínio II, uma região já reconhecida por participar da ligação aos receptores tipo-caderina. Essa região possui todas as características de uma região de ligação específica: alto potencial eletrostático, faz pontes salinas, apresenta LdH persistentes, a interface de ligação tem pouca variação de RMSD e ela está próxima a sítios hidrofóbicos.

Para exemplificar a importância de procurar regiões próximas a sítios hidrofóbicos, bem como a precisão da técnica de integração da matriz de contatos, foi escolhido o pico mais tênue identificado como um sítio hidrofóbico, ${ }_{1310} \mathrm{LI}_{1311}$, localizado entre os blocos CR11.3 e CR11.4, para um estudo tridimensional. O que se viu é que esse sítio é completamente exposto ao solvente antes do docking molecular, conforme demonstrado em rosa na imagem esquerda da Figura 43. Após a interação de Ab2.5 (em preto) com BT- $\mathrm{R}_{1}$, a glutamina (amarelo), que antes estava orientada para a esquerda (imagem esquerda), foi deslocada "para cima" e passa a interagir com os aminoácidos carregados (em azul e vermelho, imagem direita), diminuindo a superfície de contato de ${ }_{1310} \mathrm{LI}_{1311}$ (rosa) com o solvente. A glutamina (Q1314) permaneceu os 76 ns da simulação nessa posição, estabilizada por ligações de hidrogênio intramoleculares 
de BT-R $\mathrm{R}_{1}$. Como controle, BT-R1 foi submetido a uma simulação paralela, somente em água, durante $20 \mathrm{~ns}$. Os resultados de Dock2 também foram comparados.

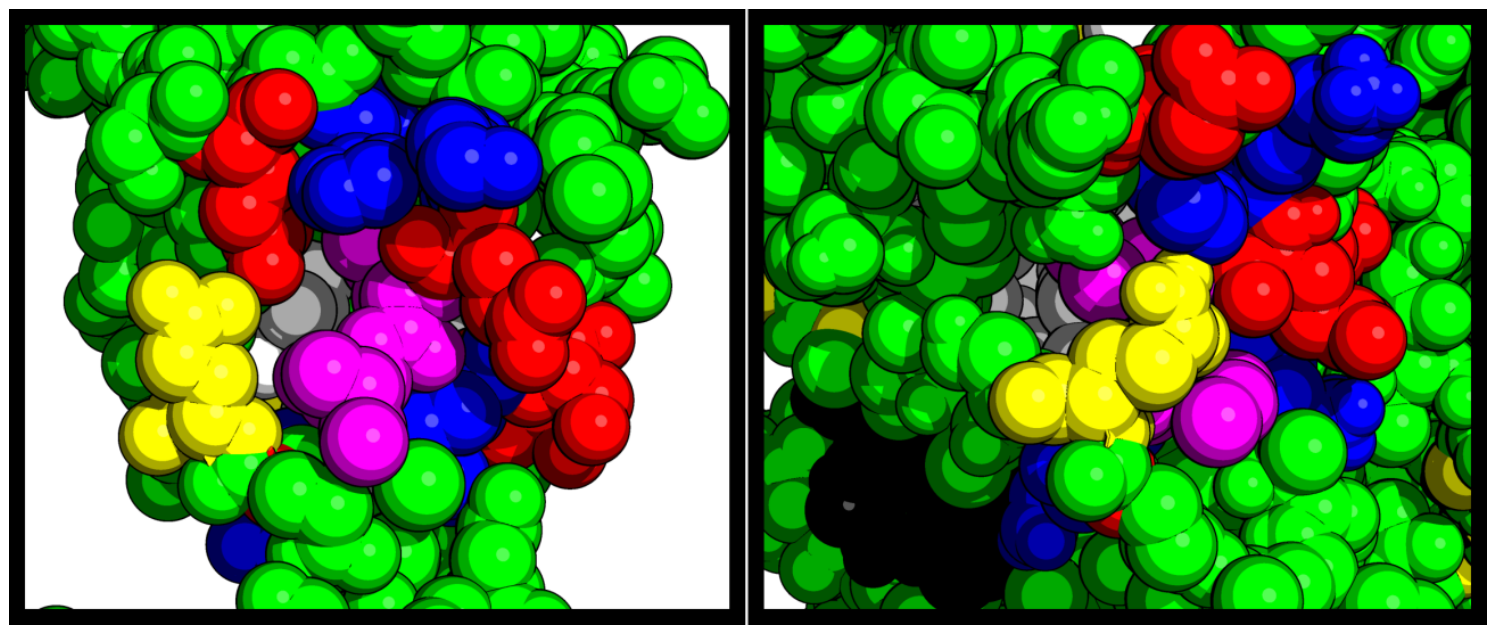

Figura 43: Sítio ${ }_{1310} \mathbf{L I}_{1311}$ antes e após interação de $\mathbf{A b 2 . 5}$ com BT-R $\mathbf{1}$. O sítio hidrofóbico ${ }_{1310} \mathrm{LI}_{1311}$ (rosa) foi identificado por meio da integração da matriz de contato entre Cry1Ab e BT- $\mathrm{R}_{1}$. O sítio é completamente exposto ao solvente antes do docking molecular, conforme demonstrado em rosa na imagem esquerda. Após a interação de Ab2.5 (em preto) com BT- $\mathrm{R}_{1}$, a glutamina (amarelo), que antes estava orientada para a esquerda (imagem esquerda), é empurrada "para cima" e passa a interagir com os aminoácidos carregados (em azul e vermelho, imagem direita), diminuindo a superfície de contato de ${ }_{1310} \mathrm{LI}_{1311}$ com o solvente. Em branco, ao centro das imagens, há um núcleo hidrofóbico.

$\mathrm{Na}$ interface de interação de Dock2, Cry1Ab interage principalmente por meio dos blocos Ab1.1, Ab1.4, Ab2.1, Ab2.5 e Ab3.1, enquanto BT-R 1 interage por meio dos blocos CR11.1, CR11.2, CR11.4, CR12.2 e CR12.4 (Tabela 10 e Tabela 11). Essas regiões apresentam características similares às encontradas em Dock1. A principal diferença encontrada é que a interface de interação de Dock2 possui menos sítios hidrofóbicos próximos, comparado a Dock1. Em geral, Dock2 parece um modelo mais estável, com RMSD da interface de interação bem equilibrado (Figura 31), apresentando um aumento significativo de interações durante a dinâmica (Figura 34) e um número maior de LdH persistentes no domínio CR12 (Tabela 10). O fato de ambos os modelos compartilharem três blocos de interação é um indicio positivo de que essas regiões direcionam a ligação da toxina ao receptor.

Alguns experimentos de SPR utilizando peptídeos sintetizados a partir das RULs indicaram a ocorrência de ligação entre Ab2.5 e CR11.1, uma ligação prevista pelo modelo Dock1 (Figura 42). Outros estudos poderão ser desenvolvidos para caracterizar melhor cada bloco participando da interface de interação. A decomposição das energias de curta distância de Van der Waals e Coulombianas podem indicar quais resíduos de 
aminoácidos dentro de cada bloco de interação são determinantes na caracterização da especificidade entre o receptor e a toxina. Além disso, estudos envolvendo o caráter hidropático de todos os blocos de interação descritos aqui tem potencial para unir os dois modelos em um âmbito mais generalizado do estudo de interações proteicas. Também será necessário analisar a presença de aminoácidos hidrofóbicos diretamente implicados na interação e daqueles indiretamente afetados, como foi descrito neste trabalho. É interessante que o trabalho continue e que sejam conduzidos ensaios in vitro capazes de validar pelo menos um dos modelos. Experimentos de cross-linking associado à espectrometria de massa e ensaios de calorimetria de titulação isotérmica (ITC) são boas alternativas. 


\section{Conclusão Geral}

Neste trabalho, uma parte importante da literatura referente a 100 anos de pesquisa com Bacillus thuringiensis foi organizada e apresentada de maneira concisa, visando estabelecer um ponto de partida para o estudo de Bt e sua aplicação na área de controle biológico. Adicionalmente, os modelos aqui propostos permitem a formulação de novas hipóteses e contribuem para esclarecimento da comunidade científica quanto à interação entre toxinas da família Cry1A e o receptor BT- $\mathrm{R}_{1}$.

Os resultados aqui apresentados foram comparados com vários trabalhos onde as interações de toxinas Cry1A foram avaliadas in vitro. O resultado dessa comparação mostrou que os modelos são pertinentes e compatíveis com vários experimentos envolvendo toxinas Cry1A e receptores tipo-caderina. Em alguns casos, foi possível extrapolar o modelo para famílias próximas, como a toxina Cry1Ia12, e até mesmo distantes, como Cry8Ka5 (Lucena, W.A. et al., 2014). No entanto, é necessária a realização de mais experimentos in vitro para indicar o modelo mais adequado. De qualquer forma, o consenso de que os blocos de interação Ab2.1, Ab2.5 e Ab3.1 participam do direcionamento de toxinas Cry1A ao receptor caderina é um resultado que contribui para a engenharia e evolução de toxinas Cry. Se comprovado in vitro, o bloco de interação Ab3.1 será a primeira região do domínio III caracterizada como uma RBR (receptor binding region). Além disso, já existem indícios em trabalhos não publicados de que o domínio I também exerça um papel no reconhecimento ao receptor, o que corrobora com os dois blocos de interação, Ab1.3 e Ab1.4, preditos nos modelos aqui propostos.

Baseado em estudos empíricos, onde observa-se a preferência de resíduos de aminoácidos hidrofóbicos nas interfaces de interação entre proteínas, foi proposto um método preciso para achar sítios hidrofóbicos próximos a regiões de alto potencial eletrostático e constataram-se os efeitos desses potenciais sobre tais sítios. A existência de uma tétrade no reconhecimento ao receptor, composta por regiões dos três domínios, explica a promiscuidade das toxinas Cry a tantos receptores e pode ajudar no estudo dos mecanismos evolutivos envolvendo essas toxinas. Por fim, os dois modelos mostram que existe uma conservação de hidropaticidade nas regiões em que as toxinas Cry1A se ligam ao receptor e motivam para a necessidade de se analisar as sequências proteicas 
em ambos os sentidos. Novos estudos com esse tipo de abordagem tem grande potencial para agregar conhecimento aos mecanismos de interação entre proteínas.

Este trabalho configura um importante passo na obtenção de uma Cry universal, que contenha uma arquitetura primordial funcional, mas cujas regiões de interação ao receptor possam ser desenhadas especificamente e aplicadas a desenhos experimentais controlados. 


\section{Referências}

ABDUL-RAUF, M., \& ELLAR, D.J. (1999). Mutations of loop 2 and loop 3 residues in domain II of Bacillus thuringiensis Cry1C delta-endotoxin affect insecticidal specificity and initial binding to Spodoptera littoralis and Aedes aegypti midgut membranes. [Research Support, Non-U.S. Gov't]. Curr Microbiol, 39(2), 94-98.

AGAISSE, H., GOMINET, M., ØKSTAD, O.A., KOLST $\varnothing$, A.-B., \& LERECLUS, D. (1999). PIcR is a pleiotropic regulator of extracellular virulence factor gene expression in Bacillus thuringiensis. Mol Microbiol, 32(5), 1043-1053. doi: 10.1046/j.1365-2958.1999.01419.x

AGAISSE, H., \& LERECLUS, D. (1994a). Expression in Bacillus subtilis of the Bacillus thuringiensis cryllIA toxin gene is not dependent on a sporulation-specific sigma factor and is increased in a spo0A mutant. [Comparative Study Research Support, Non-U.S. Gov't]. J Bacteriol, 176(15), 4734-4741.

AGAISSE, H., \& LERECLUS, D. (1994b). Structural and functional analysis of the promoter region involved in full expression of the crylllA toxin gene of Bacillus thuringiensis. [Research Support, Non-U.S. Gov't]. Mol Microbiol, 13(1), 97-107.

AGAISSE, H., \& LERECLUS, D. (1995). How does Bacillus thuringiensis produce so much insecticidal crystal protein? J Bacteriol, 177(21), 6027-6032.

AGAISSE, H., \& LERECLUS, D. (1996). STAB-SD: a Shine-Dalgarno sequence in the 5' untranslated region is a determinant of mRNA stability. [Research Support, Non-U.S. Gov't]. Mol Microbiol, 20(3), 633-643.

AGASTHYA, A.S., SHARMA, N., MOHAN, A., \& MAHAL, P. (2013). Isolation and molecular characterisation of alkaline protease producing Bacillus thuringiensis. Cell Biochem Biophys, 66(1), 45-51. doi: 10.1007/s12013-012-9396-4

AKIBA, T., ABE, Y., KITADA, S., KUSAKA, Y., ITO, A., ICHIMATSU, T., ... HARATA, K. (2009). Crystal structure of the parasporin-2 Bacillus thuringiensis toxin that recognizes cancer cells. [Comparative Study Research Support, Non-U.S. Gov't]. J Mol Biol, 386(1), 121133. doi: $10.1016 /$ j.jmb.2008.12.002

AKIBA, T., HIGUCHI, K., MIZUKI, E., EKINO, K., SHIN, T., OHBA, M., ... HARATA, K. (2006). Nontoxic crystal protein from Bacillus thuringiensis demonstrates a remarkable structural similarity to beta-pore-forming toxins. [Research Support, Non-U.S. Gov't]. Proteins, 63(1), 243-248. doi: 10.1002/prot.20843

ALMOND, B.D., \& DEAN, D.H. (1994). Intracellular proteolysis and limited diversity of the Bacillus thuringiensis CrylA family of the insecticidal crystal proteins. [Comparative Study]. Biochem Biophys Res Commun, 201(2), 788-794. doi: 10.1006/bbrc.1994.1770

ANDRUP, L., JORGENSEN, O., WILCKS, A., SMIDT, L., \& JENSEN, G.B. (1996). Mobilization of "nonmobilizable" plasmids by the aggregation-mediated conjugation system of Bacillus thuringiensis. [Research Support, Non-U.S. Gov't]. Plasmid, 36(2), 75-85. doi: 10.1006/plas.1996.0035

ANGST, B.D., MARCOZZI, C., \& MAGEE, A.I. (2001). The cadherin superfamily: diversity in form and function. [Research Support, Non-U.S. Gov't Review]. J Cell Sci, 114(Pt 4), 629-641.

ANGUS, T.A. (1954). A bacterial toxin paralysing silkworm larvae. Nature, 173(4403), 545-546.

ANGUS, T.A. (1956). Association of toxicity with protein-crystalline inclusions of Bacillus sotto Ishiwata. Can J Microbiol, 2(2), 122-131.

ARANTES, O., \& LERECLUS, D. (1991). Construction of cloning vectors for Bacillus thuringiensis. [Research Support, Non-U.S. Gov't]. Gene, 108(1), 115-119.

ARONSON, A. (2002). Sporulation and delta-endotoxin synthesis by Bacillus thuringiensis. [Review]. Cell Mol Life Sci, 59(3), 417-425. 
BARBOZA-CORONA, J.E., DE LA FUENTE-SALCIDO, N., ALVA-MURILLO, N., OCHOA-ZARZOSA, A., \& LOPEZ-MEZA, J.E. (2009). Activity of bacteriocins synthesized by Bacillus thuringiensis against Staphylococcus aureus isolates associated to bovine mastitis. [Research Support, Non-U.S. Gov't]. Vet Microbiol, 138(1-2), 179-183. doi: 10.1016/j.vetmic.2009.03.018

BARBOZA-CORONA, J.E., PARK, H.W., BIDESHI, D.K., \& FEDERICI, B.A. (2012). The 60-kilodalton protein encoded by orf2 in the cry19A operon of Bacillus thuringiensis subsp. jegathesan functions like a C-terminal crystallization domain. [Research Support, N.I.H., Extramural Research Support, Non-U.S. Gov't Research Support, U.S. Gov't, Non-P.H.S.]. Appl Environ Microbiol, 78(6), 2005-2012. doi: 10.1128/AEM.06750-11

BARLOY, F., DELECLUSE, A., NICOLAS, L., \& LECADET, M.M. (1996). Cloning and expression of the first anaerobic toxin gene from Clostridium bifermentans subsp. malaysia, encoding a new mosquitocidal protein with homologies to Bacillus thuringiensis deltaendotoxins. [Research Support, Non-U.S. Gov't]. J Bacteriol, 178(11), 3099-3105.

BARLOY, F., LECADET, M.M., \& DELECLUSE, A. (1998). Cloning and sequencing of three new putative toxin genes from Clostridium bifermentans $\mathrm{CH} 18$. [Research Support, NonU.S. Gov't]. Gene, 211(2), 293-299.

BAUM, J.A., \& GONZALEZ, J.M., JR. (1992). Mode of replication, size and distribution of naturally occurring plasmids in Bacillus thuringiensis. FEMS Microbiol Lett, 75(2-3), 143-148.

BEN-DOV, E. (2014). Bacillus thuringiensis subsp. israelensis and its dipteran-specific toxins. [Review]. Toxins (Basel), 6(4), 1222-1243. doi: 10.3390/toxins6041222

BENKERT, P., KUNZLI, M., \& SCHWEDE, T. (2009). QMEAN server for protein model quality estimation. Nucleic Acids Res, 37(Web Server issue), W510-514. doi: 10.1093/nar/gkp322

BENKERT, P., TOSATTO, S.C., \& SCHOMBURG, D. (2008). QMEAN: A comprehensive scoring function for model quality assessment. [Research Support, Non-U.S. Gov't]. Proteins, 71(1), 261-277. doi: 10.1002/prot.21715

BERMAN, H.M., BHAT, T.N., BOURNE, P.E., FENG, Z., GILLILAND, G., WEISSIG, H., \& WESTBROOK, J. (2000). The Protein Data Bank and the challenge of structural genomics. [Research Support, U.S. Gov't, Non-P.H.S. Research Support, U.S. Gov't, P.H.S.]. Nat Struct Biol, 7 Suppl, 957-959. doi: 10.1038/80734

BERMAN, H.M., WESTBROOK, J., FENG, Z., GILLILAND, G., BHAT, T.N., WEISSIG, H., . . BOURNE, P.E. (2000). The Protein Data Bank. [Research Support, U.S. Gov't, Non-P.H.S. Research Support, U.S. Gov't, P.H.S.]. Nucleic Acids Res, 28(1), 235-242.

BERRY, C., O'NEIL, S., BEN-DOV, E., JONES, A.F., MURPHY, L., QUAIL, M.A., . . PARKHILL, J. (2002). Complete sequence and organization of pBtoxis, the toxin-coding plasmid of Bacillus thuringiensis subsp. israelensis. [Research Support, Non-U.S. Gov't Research Support, U.S. Gov't, Non-P.H.S.]. Appl Environ Microbiol, 68(10), 5082-5095.

BHATTACHARYA, D., \& CHENG, J. (2013). 3Drefine: consistent protein structure refinement by optimizing hydrogen bonding network and atomic-level energy minimization. [Research Support, N.I.H., Extramural]. Proteins, 81(1), 119-131. doi: 10.1002/prot.24167

BI, Y., ZHANG, Y., SHU, C., CRICKMORE, N., WANG, Q., DU, L., .. Z ZHANG, J. (2015). Genomic sequencing identifies novel Bacillus thuringiensis Vip1/Vip2 binary and Cry8 toxins that have high toxicity to Scarabaeoidea larvae. Appl Microbiol Biotechnol, 99(2), 753-760. doi: 10.1007/s00253-014-5966-2

BIASINI, M., BIENERT, S., WATERHOUSE, A., ARNOLD, K., STUDER, G., SCHMIDT, T., . . . SCHWEDE, T. (2014). SWISS-MODEL: modelling protein tertiary and quaternary 
structure using evolutionary information. [Research Support, Non-U.S. Gov't]. Nucleic Acids Res, 42(Web Server issue), W252-258. doi: 10.1093/nar/gku340

BOONSERM, P., DAVIS, P., ELLAR, D.J., \& LI, J. (2005). Crystal structure of the mosquitolarvicidal toxin Cry4Ba and its biological implications. [Research Support, Non-U.S. Gov't]. J Mol Biol, 348(2), 363-382. doi: 10.1016/j.jmb.2005.02.013

BOONSERM, P., MO, M., ANGSUTHANASOMBAT, C., \& LESCAR, J. (2006). Structure of the functional form of the mosquito larvicidal Cry4Aa toxin from Bacillus thuringiensis at a 2.8-angstrom resolution. [Research Support, Non-U.S. Gov't]. J Bacteriol, 188(9), 33913401. doi: 10.1128/JB.188.9.3391-3401.2006

BRADLEY, D., HARKEY, M.A., KIM, M.K., BIEVER, K.D., \& BAUER, L.S. (1995). The insecticidal CrylB crystal protein of Bacillus thuringiensis ssp. thuringiensis has dual specificity to coleopteran and lepidopteran larvae. [Research Support, Non-U.S. Gov't Research Support, U.S. Gov't, Non-P.H.S.]. J Invertebr Pathol, 65(2), 162-173. doi: 10.1006/jipa.1995.1024

BRAR, S.K., VERMA, M., TYAGI, R.D., VALERO, J.R., \& SURAMPALLI, R.Y. (2009). Entomotoxicity, protease and chitinase activity of Bacillus thuringiensis fermented wastewater sludge with a high solids content. [Research Support, Non-U.S. Gov't]. Bioresour Technol, 100(19), 4317-4325. doi: 10.1016/j.biortech.2007.09.093

BRASCH, J., HARRISON, O.J., HONIG, B., \& SHAPIRO, L. (2012). Thinking outside the cell: how cadherins drive adhesion. [Research Support, N.I.H., Extramural Research Support, U.S. Gov't, Non-P.H.S. Review]. Trends Cell Biol, 22(6), 299-310. doi: 10.1016/j.tcb.2012.03.004

BRAVO, A. (1997). Phylogenetic relationships of Bacillus thuringiensis delta-endotoxin family proteins and their functional domains. [Comparative Study Research Support, Non-U.S. Gov't Review]. J Bacteriol, 179(9), 2793-2801.

BRAVO, A., AGAISSE, H., SALAMITOU, S., \& LERECLUS, D. (1996). Analysis of crylAa expression in sigE and sigK mutants of Bacillus thuringiensis. [Research Support, Non-U.S. Gov't]. Mol Gen Genet, 250(6), 734-741.

BRAVO, A., GILL, S.S., \& SOBERON, M. (2007). Mode of action of Bacillus thuringiensis Cry and Cyt toxins and their potential for insect control. [Research Support, N.I.H., Extramural Research Support, Non-U.S. Gov't Research Support, U.S. Gov't, Non-P.H.S. Review]. Toxicon, 49(4), 423-435. doi: 10.1016/j.toxicon.2006.11.022

BRAVO, A., GOMEZ, I., CONDE, J., MUNOZ-GARAY, C., SANCHEZ, J., MIRANDA, R., . . . SOBERON, M. (2004). Oligomerization triggers binding of a Bacillus thuringiensis Cry1Ab pore-forming toxin to aminopeptidase $\mathrm{N}$ receptor leading to insertion into membrane microdomains. [Research Support, Non-U.S. Gov't Research Support, U.S. Gov't, Non-P.H.S.]. Biochim Biophys Acta, 1667(1), 38-46. doi: 10.1016/j.bbamem.2004.08.013

BRAVO, A., GOMEZ, I., PORTA, H., GARCIA-GOMEZ, B.I., RODRIGUEZ-ALMAZAN, C., PARDO, L., \& SOBERON, M. (2013). Evolution of Bacillus thuringiensis Cry toxins insecticidal activity. [Review]. Microb Biotechnol, 6(1), 17-26. doi: 10.1111/j.17517915.2012.00342.x

BRAVO, A., LIKITVIVATANAVONG, S., GILL, S.S., \& SOBERON, M. (2011). Bacillus thuringiensis: A story of a successful bioinsecticide. [Review]. Insect Biochem Mol Biol, 41(7), 423-431. doi: 10.1016/j.ibmb.2011.02.006

BRAVO, A., \& SOBERÓN, M. (2008). How to cope with insect resistance to Bt toxins? Trends in Biotechnology, 26(10), 573-579. doi: http://dx.doi.org/10.1016/j.tibtech.2008.06.005 
BROOIJMANS, N., \& KUNTZ, I.D. (2003). Molecular recognition and docking algorithms.

[Research Support, U.S. Gov't, P.H.S. Review]. Annu Rev Biophys Biomol Struct, 32, 335-373. doi: 10.1146/annurev.biophys.32.110601.142532

BROOKES, G., \& BARFOOT, P. (2014). GM Crops: Global Socioeconomic and Envrionmental Impacts 1996-2012. Dorchester, UK: PG Economics Ltd.

BROWN, K.L. (1993). Transcriptional regulation of the Bacillus thuringiensis subsp. thompsoni crystal protein gene operon. [Comparative Study Research Support, Non-U.S. Gov't Research Support, U.S. Gov't, P.H.S.]. J Bacteriol, 175(24), 7951-7957.

BUCHAN, D.W., MINNECI, F., NUGENT, T.C., BRYSON, K., \& JONES, D.T. (2013). Scalable web services for the PSIPRED Protein Analysis Workbench. Nucleic Acids Res, 41(Web Server issue), W349-357. doi: 10.1093/nar/gkt381

BUDARINA, Z.I., SINEV, M.A., MAYOROV, S.G., TOMASHEVSKI, A.Y., SHMELEV, I.V., \& KUZMIN, N.P. (1994). Hemolysin II is more characteristic of Bacillus thuringiensis than Bacillus cereus. [Comparative Study]. Arch Microbiol, 161(3), 252-257.

BURGES, H.D. (1967). Standardization of Bacillus thuringiensis Products: Homology of the Standard. [10.1038/215664a0]. Nature, 215(5101), 664-665.

BUTKO, P. (2003). Cytolytic toxin Cyt1A and its mechanism of membrane damage: data and hypotheses. [Research Support, U.S. Gov't, Non-P.H.S. Review]. Appl Environ Microbiol, 69(5), 2415-2422.

CAMACHO, C.J., WENG, Z., VAJDA, S., \& DELISI, C. (1999). Free energy landscapes of encounter complexes in protein-protein association. [Research Support, Non-U.S. Gov't Research Support, U.S. Gov't, Non-P.H.S.]. Biophys J, 76(3), 1166-1178. doi: 10.1016/S00063495(99)77281-4

CARLBERG, G., TIKKANEN, L., \& ABDEL-HAMEED, A.H. (1995). Safety testing of Bacillus thuringiensis preparations, including thuringiensin, using the Salmonella assay. [Research Support, Non-U.S. Gov't]. J Invertebr Pathol, 66(1), 68-71. doi: 10.1006/jipa.1995.1062

CARROLL, J., CONVENTS, D., VAN DAMME, J., BOETS, A., VAN RIE, J., \& ELLAR, D.J. (1997). Intramolecular proteolytic cleavage of Bacillus thuringiensis Cry3A delta-endotoxin may facilitate its coleopteran toxicity. [Research Support, Non-U.S. Gov't]. J Invertebr Pathol, 70(1), 41-49. doi: 10.1006/jipa.1997.4656

CERUTTI, D.S., DUKE, R.E., DARDEN, T.A., \& LYBRAND, T.P. (2009). Staggered Mesh Ewald: An extension of the Smooth Particle-Mesh Ewald method adding great versatility. J Chem Theory Comput, 5(9), 2322. doi: 10.1021/ct9001015

CHEN, J., HUA, G., JURAT-FUENTES, J.L., ABDULLAH, M.A., \& ADANG, M.J. (2007). Synergism of Bacillus thuringiensis toxins by a fragment of a toxin-binding cadherin. [Research Support, N.I.H., Extramural Research Support, Non-U.S. Gov't Research Support, U.S. Gov't, Non-P.H.S.]. Proc Natl Acad Sci U S A, 104(35), 13901-13906. doi: 10.1073/pnas.0706011104

CHEN, V.B., ARENDALL, W.B., 3RD, HEADD, J.J., KEEDY, D.A., IMMORMINO, R.M., KAPRAL, G.J., ... RICHARDSON, D.C. (2010). MolProbity: all-atom structure validation for macromolecular crystallography. [Research Support, N.I.H., Extramural]. Acta Crystallogr D Biol Crystallogr, 66(Pt 1), 12-21. doi: 10.1107/S0907444909042073

CHEN, X.J., CURTISS, A., ALCANTARA, E., \& DEAN, D.H. (1995). Mutations in domain I of Bacillus thuringiensis delta-endotoxin CrylAb reduce the irreversible binding of toxin to manduca sexta brush border membrane vesicles. [Comparative Study Research Support, U.S. Gov't, P.H.S.]. J Biol Chem, 270(11), 6412-6419. 
CHIGALEICHIK, A.G. (1976). [Chitinase of Bacillus thuringiensis]. Mikrobiologiia, 45(6), 966-972.

CHOUGULE, N.P., \& BONNING, B.C. (2012). Toxins for transgenic resistance to hemipteran pests. [Review]. Toxins (Basel), 4(6), 405-429. doi: 10.3390/toxins4060405

CLAIRMONT, F.R., MILNE, R.E., PHAM, V.T., CARRIERE, M.B., \& KAPLAN, H. (1998). Role of DNA in the activation of the Cry1A insecticidal crystal protein from Bacillus thuringiensis. [Research Support, Non-U.S. Gov't]. J Biol Chem, 273(15), 9292-9296.

COHEN, S., ALBECK, S., BEN-DOV, E., CAHAN, R., FIRER, M., ZARITSKY, A., \& DYM, O. (2011). Cyt1Aa toxin: crystal structure reveals implications for its membrane-perforating function. [Research Support, Non-U.S. Gov't]. J Mol Biol, 413(4), 804-814. doi: 10.1016/j.jmb.2011.09.021

COHEN, S., DYM, O., ALBECK, S., BEN-DOV, E., CAHAN, R., FIRER, M., \& ZARITSKY, A. (2008). High-resolution crystal structure of activated Cyt2Ba monomer from Bacillus thuringiensis subsp. israelensis. [Research Support, Non-U.S. Gov't]. J Mol Biol, 380(5), 820-827. doi: 10.1016/j.jmb.2008.05.010

COLE, C., BARBER, J.D., \& BARTON, G.J. (2008). The Jpred 3 secondary structure prediction server. [Research Support, Non-U.S. Gov't]. Nucleic Acids Res, 36(Web Server issue), W197-201. doi: 10.1093/nar/gkn238

COMEAU, S.R., GATCHELL, D.W., VAJDA, S., \& CAMACHO, C.J. (2004a). ClusPro: a fully automated algorithm for protein-protein docking. Nucleic Acids Res, 32(Web Server issue), W96-99. doi: 10.1093/nar/gkh354

COMEAU, S.R., GATCHELL, D.W., VAJDA, S., \& CAMACHO, C.J. (2004b). ClusPro: an automated docking and discrimination method for the prediction of protein complexes. [Comparative Study Evaluation Studies Research Support, U.S. Gov't, P.H.S. Validation Studies]. Bioinformatics, 20(1), 45-50.

CONTRERAS, E., SCHOPPMEIER, M., REAL, M.D., \& RAUSELL, C. (2013). Sodium solute symporter and cadherin proteins act as Bacillus thuringiensis Cry3Ba toxin functional receptors in Tribolium castaneum. [Research Support, Non-U.S. Gov't]. J Biol Chem, 288(25), 18013-18021. doi: 10.1074/jbc.M113.474445

COSTECHAREYRE, D., DRIDI, B., RAHBE, Y., \& CONDEMINE, G. (2010). Cyt toxin expression reveals an inverse regulation of insect and plant virulence factors of Dickeya dadantii. [Research Support, Non-U.S. Gov't]. Environ Microbiol, 12(12), 3290-3301. doi: 10.1111/j.1462-2920.2010.02305.x

CRICKMORE, N. (2000). The diversity of Bacillus thuringiensis $\delta$-endotoxins. In J.-F. Charles, A. Delécluse \& C.-L. Roux (Eds.), Entomopathogenic Bacteria: from Laboratory to Field Application (pp. 65-79): Springer Netherlands.

CRICKMORE, N., BAUM, J., BRAVO, A., LERECLUS, D., NARVA, K., SAMPSON, K., . . ZEIGLER, D.R. (2014). Bacillus thuringiensis toxin nomenclature. http://www.btnomenclature.info/

CRICKMORE, N., ZEIGLER, D.R., FEITELSON, J., SCHNEPF, E., VAN RIE, J., LERECLUS, D., . . DEAN, D.H. (1998). Revision of the nomenclature for the Bacillus thuringiensis pesticidal crystal proteins. [Research Support, U.S. Gov't, Non-P.H.S. Review]. Microbiol Mol Biol Rev, 62(3), 807-813.

DALHAMMAR, G., \& STEINER, H. (1984). Characterization of inhibitor A, a protease from Bacillus thuringiensis which degrades attacins and cecropins, two classes of antibacterial proteins in insects. [Research Support, Non-U.S. Gov't]. Eur J Biochem, 139(2), 247-252.

DAVIS, I.W., LEAVER-FAY, A., CHEN, V.B., BLOCK, J.N., KAPRAL, G.J., WANG, X., . . . RICHARDSON, D.C. (2007). MolProbity: all-atom contacts and structure validation for proteins and nucleic acids. [Research Support, N.I.H., Extramural Research Support, 
Non-U.S. Gov't]. Nucleic Acids Res, 35(Web Server issue), W375-383. doi: $10.1093 / \mathrm{nar} / \mathrm{gkm} 216$

DE MAAGD, R.A., BRAVO, A., BERRY, C., CRICKMORE, N., \& SCHNEPF, H.E. (2003). Structure, diversity, and evolution of protein toxins from spore-forming entomopathogenic bacteria. [Research Support, Non-U.S. Gov't Review]. Annu Rev Genet, 37, 409-433. doi: 10.1146/annurev.genet.37.110801.143042

DE MAAGD, R.A., BRAVO, A., \& CRICKMORE, N. (2001). How Bacillus thuringiensis has evolved specific toxins to colonize the insect world. Trends in Genetics, 17(4), 193-199. doi: http://dx.doi.org/10.1016/S0168-9525(01)02237-5

DEBRECZENI, J.E., \& EMSLEY, P. (2012). Handling ligands with Coot. [Research Support, NonU.S. Gov't]. Acta Crystallogr D Biol Crystallogr, 68(Pt 4), 425-430. doi: 10.1107/S0907444912000200

DELANO, W.L. (2004). Use of PYMOL as a communications tool for molecular science. Abstracts of Papers of the American Chemical Society, 228, U313-U314.

DELANO, W.L. (2009). PyMOL molecular viewer: Updates and refinements. Abstracts of Papers of the American Chemical Society, 238.

DELANO, W.L., \& LAM, J.W. (2005). PyMOL: A communications tool for computational models. Abstracts of Papers of the American Chemical Society, 230, U1371-U1372.

DENG, C., PENG, Q., SONG, F., \& LERECLUS, D. (2014). Regulation of cry gene expression in Bacillus thuringiensis. [Research Support, Non-U.S. Gov't Review]. Toxins (Basel), 6(7), 2194-2209. doi: 10.3390/toxins6072194

DENG, C., SLAMTI, L., RAYMOND, B., LIU, G., LEMY, C., GOMINET, M., .. SONG, F. (2015). Division of labour and terminal differentiation in a novel Bacillus thuringiensis strain. [Research Support, Non-U.S. Gov't]. ISME J, 9(2), 286-296. doi: 10.1038/ismej.2014.122

DERBYSHIRE, D.J., CARROLL, J., ELLAR, D.J., \& LI, J. (2013). Lepidoptera-specific toxin Cry1AC from Bacillus thuringiensis ssp. kurstaki HD-73: Protein Data Bank, Rutgers University.

DERBYSHIRE, D.J., ELLAR, D.J., \& LI, J. (2001). Crystallization of the Bacillus thuringiensis toxin Cry1Ac and its complex with the receptor ligand N-acetyl-D-galactosamine. [Research Support, Non-U.S. Gov't]. Acta Crystallogr D Biol Crystallogr, 57(Pt 12), 1938-1944.

DERVYN, E., PONCET, S., KLIER, A., \& RAPOPORT, G. (1995). Transcriptional regulation of the crylVD gene operon from Bacillus thuringiensis subsp. israelensis. [Research Support, Non-U.S. Gov't]. J Bacteriol, 177(9), 2283-2291.

DONOVAN, W.P., ENGLEMAN, J.T., DONOVAN, J.C., BAUM, J.A., BUNKERS, G.J., CHI, D.J., . . WALTERS, M.R. (2006). Discovery and characterization of Sip1A: A novel secreted protein from Bacillus thuringiensis with activity against coleopteran larvae. Appl Microbiol Biotechnol, 72(4), 713-719. doi: 10.1007/s00253-006-0332-7

DORSCH, J.A., CANDAS, M., GRIKO, N.B., MAATY, W.S., MIDBOE, E.G., VADLAMUDI, R.K., \& BULLA, L.A., JR. (2002). Cry1A toxins of Bacillus thuringiensis bind specifically to a region adjacent to the membrane-proximal extracellular domain of $B T-R(1)$ in Manduca sexta: involvement of a cadherin in the entomopathogenicity of Bacillus thuringiensis. [Research Support, Non-U.S. Gov't Research Support, U.S. Gov't, NonP.H.S.]. Insect Biochem Mol Biol, 32(9), 1025-1036.

DORUK, T., AVICAN, U., CAMCI, I.Y., \& GEDIK, S.T. (2013). Overexpression of polyphosphate kinase gene (ppk) increases bioinsecticide production by Bacillus thuringiensis.

[Research Support, Non-U.S. Gov't]. Microbiol Res, 168(4), 199-203. doi: 10.1016/j.micres.2012.11.009 
DU, C., \& NICKERSON, K.W. (1996). Bacillus thuringiensis HD-73 Spores Have Surface-Localized Cry1Ac Toxin: Physiological and Pathogenic Consequences. Appl Environ Microbiol, 62(10), 3722-3726.

DU, L., QIU, L., PENG, Q., LERECLUS, D., ZHANG, J., SONG, F., \& HUANG, D. (2012). Identification of the Promoter in the Intergenic Region between orf1 and cry8Ea1 Controlled by Sigma H Factor. Appl Environ Microbiol, 78(12), 4164-4168.

DULMAGE, H.T. (1970). Insecticidal activity of HD-1, a new isolate of Bacillus thuringiensis var. alesti. J Invertebr Pathol, 15(2), 232-239. doi: http://dx.doi.org/10.1016/00222011(70)90240-5

DULMAGE, H.T., \& K., A. (1982). Distribution of Bacillus thuringiensis in nature. In E. Kurstak (Ed.), Microbial and Viral Pesticides (pp. 209-237). New York: Marcel Dekker.

DUNNE, J., HANBY, A.M., POULSOM, R., JONES, T.A., SHEER, D., CHIN, W.G., . . OWEN, M.J. (1995). Molecular cloning and tissue expression of FAT, the human homologue of the Drosophila fat gene that is located on chromosome $4 q 34-q 35$ and encodes a putative adhesion molecule. Genomics, 30(2), 207-223.

EDGAR, R.C. (2004). MUSCLE: multiple sequence alignment with high accuracy and high throughput. [Comparative Study Evaluation Studies]. Nucleic Acids Res, 32(5), 17921797. doi: $10.1093 /$ nar/gkh340

EMSLEY, P., \& COWTAN, K. (2004). Coot: model-building tools for molecular graphics. [Research Support, Non-U.S. Gov't]. Acta Crystallogr D Biol Crystallogr, 60(Pt 12 Pt 1), 2126-2132. doi: 10.1107/S0907444904019158

ESPINASSE, S., CHAUFAUX, J., BUISSON, C., PERCHAT, S., GOHAR, M., BOURGUET, D., \& SANCHIS, V. (2003). Occurrence and Linkage Between Secreted Insecticidal Toxins in Natural Isolates of Bacillus thuringiensis. Curr Microbiol, 47(6), 501-507. doi: 10.1007/s00284-003-4097-2

ESTRUCH, J.J., WARREN, G.W., MULLINS, M.A., NYE, G.J., CRAIG, J.A., \& KOZIEL, M.G. (1996). Vip3A, a novel Bacillus thuringiensis vegetative insecticidal protein with a wide spectrum of activities against lepidopteran insects. Proc Natl Acad Sci U S A, 93(11), 5389-5394.

EVDOKIMOV, A.G., MOSHIRI, F., STURMAN, E.J., RYDEL, T.J., ZHENG, M., SEALE, J.W., \& FRANKLIN, S. (2014). Structure of the full-length insecticidal protein Cry1Ac reveals intriguing details of toxin packaging into in vivo formed crystals. Protein Science, 23(11), 1491-1497. doi: 10.1002/pro.2536

FARIA, C.A., WACKERS, F.L., PRITCHARD, J., BARRETT, D.A., \& TURLINGS, T.C.J. (2007). High Susceptibility of Bt Maize to Aphids Enhances the Performance of Parasitoids of Lepidopteran Pests. PLoS One, 2(7). doi: ARTN e600 DOI 10.1371/journal.pone.0000600

FEDHILA, S., NEL, P., \& LERECLUS, D. (2002). The InhA2 metalloprotease of Bacillus thuringiensis strain 407 is required for pathogenicity in insects infected via the oral route. [Research Support, Non-U.S. Gov't]. J Bacteriol, 184(12), 3296-3304.

FERNANDEZ-FUENTES, N., MADRID-ALISTE, C.J., RAI, B.K., FAJARDO, J.E., \& FISER, A. (2007). M4T: a comparative protein structure modeling server. [Research Support, N.I.H., Extramural]. Nucleic Acids Res, 35(Web Server issue), W363-368. doi: 10.1093/nar/gkm341

FERNANDEZ-LUNA, M.T., LANZ-MENDOZA, H., GILL, S.S., BRAVO, A., SOBERON, M., \& MIRANDA-RIOS, J. (2010). An $\alpha$-amylase is a novel receptor for Bacillus thuringiensis ssp. israelensis Cry4Ba and Cry11Aa toxins in the malaria vector mosquito Anopheles albimanus (Diptera: Culicidae). Environ Microbiol, 12(3), 746-757. doi: 10.1111/j.14622920.2009.02117.x 
FISCHER, E. (1894). Einfluss der Configuration auf die Wirkung der Enzyme. Berichte der deutschen chemischen Gesellschaft, 27(3), 2985-2993. doi: 10.1002/cber.18940270364

FISCHHOFF, D.A., BOWDISH, K.S., PERLAK, F.J., MARRONE, P.G., MCCORMICK, S.M., NIEDERMEYER, J.G., . . FRALEY, R.T. (1987). Insect Tolerant Transgenic Tomato Plants. Bio-Technology, 5(8), 807-813. doi: Doi 10.1038/Nbt0887-807

FREDERIKSEN, K., ROSENQUIST, H., JORGENSEN, K., \& WILCKS, A. (2006). Occurrence of natural Bacillus thuringiensis contaminants and residues of Bacillus thuringiensis-based insecticides on fresh fruits and vegetables. Appl Environ Microbiol, 72(5), 3435-3440. doi: Doi 10.1128/Aem.72.5.3435-3440.2006

GAHAN, L.J., GOULD, F., \& HECKEL, D.G. (2001). Identification of a gene associated with Bt resistance in Heliothis virescens. [Research Support, U.S. Gov't, Non-P.H.S.]. Science, 293(5531), 857-860. doi: 10.1126/science.1060949

GALITSKY, N., CODY, V., WOJTCZAK, A., GHOSH, D., LUFT, J.R., PANGBORN, W., \& ENGLISH, L. (2001). Structure of the insecticidal bacterial delta-endotoxin Cry3Bb1 of Bacillus thuringiensis. Acta Crystallogr D Biol Crystallogr, 57(Pt 8), 1101-1109.

GAMMON, K., JONES, G.W., HOPE, S.J., DE OLIVEIRA, C.M., REGIS, L., SILVA FILHA, M.H., . . . BERRY, C. (2006). Conjugal transfer of a toxin-coding megaplasmid from Bacillus thuringiensis subsp. israelensis to mosquitocidal strains of Bacillus sphaericus. [Research Support, Non-U.S. Gov't]. Appl Environ Microbiol, 72(3), 1766-1770. doi: 10.1128/AEM.72.3.1766-1770.2006

GAVIRIA RIVERA, A.M., GRANUM, P.E., \& PRIEST, F.G. (2000). Common occurrence of enterotoxin genes and enterotoxicity in Bacillus thuringiensis. [Research Support, NonU.S. Gov't]. FEMS Microbiol Lett, 190(1), 151-155.

GE, B., BIDESHI, D., MOAR, W.J., \& FEDERICI, B.A. (1998). Differential effects of helper proteins encoded by the cry2A and cry11A operons on the formation of Cry2A inclusions in Bacillus thuringiensis. [Research Support, Non-U.S. Gov't]. FEMS Microbiol Lett, 165(1), 35-41.

GOHAR, M., FAEGRI, K., PERCHAT, S., RAVNUM, S., OKSTAD, O.A., GOMINET, M., . . LERECLUS, D. (2008). The PlcR virulence regulon of Bacillus cereus. [Research Support, Non-U.S. Gov't]. PLoS One, 3(7), e2793. doi: 10.1371/journal.pone.0002793

GOLDBERG, L.J., \& MARGALIT, J. (1977). A bacterial spore demonstrating rapid larvicidal activity against Anopheles sergentii, Uranotaenia unguiculata, Culex univittatus, Aedes aegypti and Culex pipiens. Mosquito News, 37(3), 355-358.

GOMAA, E.Z. (2012). Chitinase production by Bacillus thuringiensis and Bacillus licheniformis: their potential in antifungal biocontrol. J Microbiol, 50(1), 103-111. doi: 10.1007/s12275-012-1343-y

GOMEZ, I., ARENAS, I., BENITEZ, I., MIRANDA-RIOS, J., BECERRIL, B., GRANDE, R., . . SOBERON, M. (2006). Specific epitopes of domains II and III of Bacillus thuringiensis Cry1Ab toxin involved in the sequential interaction with cadherin and aminopeptidase-N receptors in Manduca sexta. [Research Support, Non-U.S. Gov't Research Support, U.S. Gov't, Non-P.H.S.]. J Biol Chem, 281(45), 34032-34039. doi: 10.1074/jbc.M604721200

GOMEZ, I., SANCHEZ, J., MIRANDA, R., BRAVO, A., \& SOBERON, M. (2002). Cadherin-like receptor binding facilitates proteolytic cleavage of helix alpha-1 in domain I and oligomer pre-pore formation of Bacillus thuringiensis Cry1Ab toxin. [Research Support, Non-U.S. Gov't]. FEBS Lett, 513(2-3), 242-246.

GONZALEZ-REYES, A. (2003). Stem cells, niches and cadherins: a view from Drosophila. [Research Support, Non-U.S. Gov't Review]. J Cell Sci, 116(Pt 6), 949-954.

GONZALEZ, J.M., JR., BROWN, B.J., \& CARLTON, B.C. (1982). Transfer of Bacillus thuringiensis plasmids coding for delta-endotoxin among strains of $B$. thuringiensis and $B$. cereus. [Research Support, Non-U.S. Gov't]. Proc Natl Acad Sci U S A, 79(22), 6951-6955. 
GONZALEZ, J.M., JR., DULMAGE, H.T., \& CARLTON, B.C. (1981). Correlation between specific plasmids and delta-endotoxin production in Bacillus thuringiensis. [Research Support, U.S. Gov't, Non-P.H.S.]. Plasmid, 5(3), 352-365.

GONZÁLEZ JR, J., \& CARLTON, B.C. (1984). A large transmissible plasmid is required for crystal toxin production in Bacillus thuringiensis variety israelensis. Plasmid, 11(1), 28-38. doi: http://dx.doi.org/10.1016/0147-619X(84)90004-0

GONZALEZ, M.R., BISCHOFBERGER, M., PERNOT, L., VAN DER GOOT, F.G., \& FRECHE, B. (2008). Bacterial pore-forming toxins: the (w)hole story? [Research Support, Non-U.S. Gov't Review]. Cell Mol Life Sci, 65(3), 493-507. doi: 10.1007/s00018-007-7434-y

GRIFFITTS, J.S., HASLAM, S.M., YANG, T., GARCZYNSKI, S.F., MULLOY, B., MORRIS, H., . . AROIAN, R.V. (2005). Glycolipids as Receptors for Bacillus thuringiensis Crystal Toxin. Science, 307(5711), 922-925.

GRIFFITTS, J.S., HUFFMAN, D.L., WHITACRE, J.L., BARROWS, B.D., MARROQUIN, L.D., MÜLLER, R., ... AROIAN, R.V. (2003). Resistance to a Bacterial Toxin Is Mediated by Removal of a Conserved Glycosylation Pathway Required for Toxin-Host Interactions. Journal of Biological Chemistry, 278(46), 45594-45602.

GRIKO, N., CANDAS, M., ZHANG, X., JUNKER, M., \& BULLA, L.A., JR. (2004). Selective antagonism to the cadherin BT-R1 interferes with calcium-induced adhesion of epithelial membrane vesicles. Biochemistry, 43(5), 1393-1400. doi: 10.1021/bi0355692

GROCHULSKI, P., MASSON, L., BORISOVA, S., PUSZTAI-CAREY, M., SCHWARTZ, J.L., BROUSSEAU, R., \& CYGLER, M. (1995). Bacillus thuringiensis CryIA(a) insecticidal toxin: crystal structure and channel formation. [Research Support, Non-U.S. Gov't]. J Mol Biol, 254(3), 447-464.

GROSSI-DE-SA, M.F., QUEZADO DE MAGALHAES, M., SILVA, M.S., SILVA, S.M., DIAS, S.C., NAKASU, E.Y., . . FIGUEIRA, E.L. (2007). Susceptibility of Anthonomus grandis (cotton boll weevil) and Spodoptera frugiperda (fall armyworm) to a cry1ia-type toxin from a Brazilian Bacillus thuringiensis strain. [Research Support, Non-U.S. Gov't]. J Biochem Mol Biol, 4O(5), 773-782.

GUO, S., YE, S., LIU, Y., WEI, L., XUE, J., WU, H., . . RAO, Z. (2009). Crystal structure of Bacillus thuringiensis Cry8Ea1: An insecticidal toxin toxic to underground pests, the larvae of Holotrichia parallela. [Research Support, Non-U.S. Gov't]. J Struct Biol, 168(2), 259-266. doi: 10.1016/j.jsb.2009.07.004

HAIDER, M.Z., KNOWLES, B.H., \& ELLAR, D.J. (1986). Specificity of Bacillus thuringiensis var. colmeri insecticidal delta-endotoxin is determined by differential proteolytic processing of the protoxin by larval gut proteases. [Comparative Study Research Support, Non-U.S. Gov't]. Eur J Biochem, 156(3), 531-540.

HAMMES, G.G. (2002). Multiple conformational changes in enzyme catalysis. [Research Support, Non-U.S. Gov't Research Support, U.S. Gov't, P.H.S. Review]. Biochemistry, 41(26), 8221-8228.

HANNAY, C.L. (1953). Crystalline inclusions in aerobic spore-forming bacteria. Nature, 172(4387), 1004.

HANNAY, C.L., \& FITZ-JAMES, P. (1955). The protein crystals of Bacillus thuringiensis Berliner. Can J Microbiol, 1(8), 694-710.

HEIMPEL, A.M. (1967). A critical review of Bacillus thuringiensis var. thuringiensis Berliner and other crystalliferous bacteria. [Review]. Annu Rev Entomol, 12, 287-322. doi: 10.1146/annurev.en.12.010167.001443

HEIMPEL, A.M., \& ANGUS, T.A. (1958). The taxonomy of insect pathogens related to Bacillus cereus Frankland and Frankland. Can J Microbiol, 4(5), 531-541. 
HELGASON, E., OKSTAD, O.A., CAUGANT, D.A., JOHANSEN, H.A., FOUET, A., MOCK, M., . . . KOLSTO, A.B. (2000). Bacillus anthracis, Bacillus cereus, and Bacillus thuringiensis--one species on the basis of genetic evidence. [Comparative Study Research Support, NonU.S. Gov't Research Support, U.S. Gov't, Non-P.H.S.]. Appl Environ Microbiol, 66(6), 2627-2630.

HENNER, D.J., YANG, M., CHEN, E., HELLMISS, R., RODRIGUEZ, H., \& LOW, M.G. (1988). Sequence of the Bacillus thuringiensis phosphatidylinositol specific phospholipase $C$. Nucleic Acids Res, 16(21), 10383.

HERRERO, S., GECHEV, T., BAKKER, P.L., MOAR, W.J., \& DE MAAGD, R.A. (2005). Bacillus thuringiensis Cry1Ca-resistant Spodoptera exigua lacks expression of one of four Aminopeptidase N genes. [Research Support, Non-U.S. Gov't]. BMC Genomics, 6, 96. doi: 10.1186/1471-2164-6-96

HOFTE, H., \& WHITELEY, H.R. (1989). Insecticidal crystal proteins of Bacillus thuringiensis. [Research Support, U.S. Gov't, P.H.S. Review]. Microbiol Rev, 53(2), 242-255.

HONDA, T., SHIBA, A., SEO, S., YAMAMOTO, J., MATSUYAMA, J., \& MIWATANI, T. (1991). Identity of hemolysins produced by Bacillus thuringiensis and Bacillus cereus. [Comparative Study Research Support, Non-U.S. Gov't]. FEMS Microbiol Lett, 63(2-3), 205-209.

HOSSAIN, D.M., SHITOMI, Y., MORIYAMA, K., HIGUCHI, M., HAYAKAWA, T., MITSUI, T., . . . HORI, H. (2004). Characterization of a novel plasma membrane protein, expressed in the midgut epithelia of Bombyx mori, that binds to Cry1A toxins. [Research Support, Non-U.S. Gov't]. Appl Environ Microbiol, 70(8), 4604-4612. doi: 10.1128/AEM.70.8.4604-4612.2004

HUA, G., JURAT-FUENTES, J.L., \& ADANG, M.J. (2004). Bt-R1a extracellular cadherin repeat 12 mediates Bacillus thuringiensis Cry1Ab binding and cytotoxicity. [Research Support, Non-U.S. Gov't Research Support, U.S. Gov't, Non-P.H.S. Research Support, U.S. Gov't, P.H.S.]. J Biol Chem, 279(27), 28051-28056. doi: 10.1074/jbc.M400237200

HUI, F., SCHEIB, U., HU, Y., SOMMER, R.J., AROIAN, R.V., \& GHOSH, P. (2012). Structure and glycolipid binding properties of the nematicidal protein Cry5B. [Research Support, N.I.H., Extramural Research Support, U.S. Gov't, Non-P.H.S.]. Biochemistry, 51(49), 9911-9921. doi: 10.1021/bi301386q

HUSZ, B. (1928). Bacillus thuringiensis Berl., a bacterium pathogenic to corn borer larvae. Int. Corn Borer Invest. Sci. Rep., 1, 191-193.

IBRAHIM, M.A., GRIKO, N., JUNKER, M., \& BULLA, L.A. (2010). Bacillus thuringiensis: a genomics and proteomics perspective. [Review]. Bioeng Bugs, 1(1), 31-50. doi: 10.4161/bbug.1.1.10519

JANIN, J., HENRICK, K., MOULT, J., EYCK, L.T., STERNBERG, M.J., VAJDA, S., . . WODAK, S.J. (2003). CAPRI: a Critical Assessment of PRedicted Interactions. [Research Support, Non-U.S. Gov't]. Proteins, 52(1), 2-9. doi: 10.1002/prot.10381

JARRETT, P., \& STEPHENSON, M. (1990). Plasmid transfer between strains of Bacillus thuringiensis infecting Galleria mellonella and Spodoptera littoralis. Appl Environ Microbiol, 56(6), 1608-1614.

JENSEN, G.B., ANDRUP, L., WILCKS, A., SMIDT, L., \& POULSEN, O.M. (1996). The aggregationmediated conjugation system of Bacillus thuringiensis subsp. israelensis: host range and kinetics of transfer. [Research Support, Non-U.S. Gov't]. Curr Microbiol, 33(4), 228236.

JIN, X., WALKER, M.A., FELSOVALYI, K., VENDOME, J., BAHNA, F., MANNEPALLI, S., . . SHAPIRO, L. (2012). Crystal structures of Drosophila N-cadherin ectodomain regions reveal a 
widely used class of $\mathrm{Ca}(2)+-$ free interdomain linkers. [Research Support, N.I.H., Extramural Research Support, Non-U.S. Gov't Research Support, U.S. Gov't, NonP.H.S.]. Proc Natl Acad Sci U S A, 109(3), E127-134. doi: 10.1073/pnas.1117538108

JISHA, V.N., SMITHA, R.B., \& BENJAMIN, S. (2013). An Overview on the Crystal Toxins from \&lt;i\&gt;Bacillus thuringiensis\&lt;/i\&gt. Advances in Microbiology, 03(05), 462-472. doi: 10.4236/aim.2013.35062

JONES, G.W., NIELSEN-LEROUX, C., YANG, Y., YUAN, Z., DUMAS, V.F., MONNERAT, R.G., \& BERRY, C. (2007). A new Cry toxin with a unique two-component dependency from Bacillus sphaericus. [Research Support, Non-U.S. Gov't]. FASEB J, 21(14), 4112-4120. doi: 10.1096/fj.07-8913com

JURAT-FUENTES, J.L., \& ADANG, M.J. (2006). The Heliothis virescens cadherin protein expressed in Drosophila S2 cells functions as a receptor for Bacillus thuringiensis Cry1A but not Cry1Fa toxins. [Research Support, U.S. Gov't, Non-P.H.S.]. Biochemistry, 45(32), 9688-9695. doi: 10.1021/bi0606703

JURAT-FUENTES, J.L., GAHAN, L.J., GOULD, F.L., HECKEL, D.G., \& ADANG, M.J. (2004). The HevCaLP protein mediates binding specificity of the Cry1A class of Bacillus thuringiensis toxins in Heliothis virescens. [Research Support, U.S. Gov't, Non-P.H.S.]. Biochemistry, 43(44), 14299-14305. doi: 10.1021/bi048500i

KAUR, S. (2000). Molecular approaches towards development of novel Bacillus thuringiensis biopesticides. World Journal of Microbiology \& Biotechnology, 16(8-9), 781-793. doi: Doi 10.1023/A:1008931207374

KAWAR, Z.S., VAN DIE, I., \& CUMMINGS, R.D. (2002). Molecular cloning and enzymatic characterization of a UDP-GalNAc:GIcNAc(beta)-R beta1,4-Nacetylgalactosaminyltransferase from Caenorhabditis elegans. [Research Support, U.S. Gov't, P.H.S.]. J Biol Chem, 277(38), 34924-34932. doi: 10.1074/jbc.M206112200

KELKER, M.S., BERRY, C., EVANS, S.L., PAI, R., MCCASKILL, D.G., WANG, N.X., . . NARVA, K.E. (2014). Structural and biophysical characterization of Bacillus thuringiensis insecticidal proteins Cry34Ab1 and Cry35Ab1. [Research Support, N.I.H., Extramural Research Support, U.S. Gov't, Non-P.H.S.]. PLoS One, 9(11), e112555. doi: 10.1371/journal.pone.0112555

KELLER, M., SNEH, B., STRIZHOV, N., PRUDOVSKY, E., REGEV, A., KONCZ, C., . . ZILBERSTEIN, A. (1996). Digestion of delta-endotoxin by gut proteases may explain reduced sensitivity of advanced instar larvae of Spodoptera littoralis to CryIC. [Research Support, Non-U.S. Gov't]. Insect Biochem Mol Biol, 26(4), 365-373.

KELLEY, L.A., \& STERNBERG, M.J.E. (2009). Protein structure prediction on the Web: a case study using the Phyre server. [10.1038/nprot.2009.2]. Nat. Protocols, 4(3), 363-371.

KIEFER, F., ARNOLD, K., KUNZLI, M., BORDOLI, L., \& SCHWEDE, T. (2009). The SWISS-MODEL Repository and associated resources. [Research Support, N.I.H., Extramural Research Support, Non-U.S. Gov't]. Nucleic Acids Res, 37(Database issue), D387-392. doi: 10.1093/nar/gkn750

KITCHEN, D.B., DECORNEZ, H., FURR, J.R., \& BAJORATH, J. (2004). Docking and scoring in virtual screening for drug discovery: methods and applications. [Review]. Nat Rev Drug Discov, 3(11), 935-949. doi: 10.1038/nrd1549

KNIGHT, P.J., CRICKMORE, N., \& ELLAR, D.J. (1994). The receptor for Bacillus thuringiensis $\mathrm{CrylA}(\mathrm{c})$ delta-endotoxin in the brush border membrane of the lepidopteran Manduca sexta is aminopeptidase N. [Research Support, Non-U.S. Gov't]. Mol Microbiol, 11(3), 429-436.

KOSHLAND, D.E., JR. (1963). Correlation of Structure and Function in Enzyme Action. Science, 142(3599), 1533-1541. 
KOZAKOV, D., BEGLOV, D., BOHNUUD, T., MOTTARELLA, S.E., XIA, B., HALL, D.R., \& VAJDA, S. (2013). How good is automated protein docking? Proteins: Structure, Function, and Bioinformatics, 81(12), 2159-2166. doi: 10.1002/prot.24403

KOZAKOV, D., BRENKE, R., COMEAU, S.R., \& VAJDA, S. (2006). PIPER: an FFT-based protein docking program with pairwise potentials. [Research Support, N.I.H., Extramural Research Support, Non-U.S. Gov't]. Proteins, 65(2), 392-406. doi: 10.1002/prot.21117

KOZIEL, M.G., BELAND, G.L., BOWMAN, C., CAROZZI, N.B., CRENSHAW, R., CROSSLAND, L., .. EVOLA, S.V. (1993). Field Performance of Elite Transgenic Maize Plants Expressing an Insecticidal Protein Derived from Bacillus thuringiensis. [10.1038/nbt0293-194]. Nat Biotech, 11(2), 194-200.

KRIEG, A. (1971). Concerning $\alpha$-exotoxin produced by vegetative cells of Bacillus thuringiensis and Bacillus cereus. J Invertebr Pathol, 17(1), 134-135. doi: http://dx.doi.org/10.1016/0022-2011(71)90137-6

KRIEG, A., HUGER, A.M., LANGENBRUCH, G.A., \& SCHNETTER, W. (1983). Bacillus thuringiensis var. tenebrionis: ein neuer, gegenüber Larven von Coleopteren wirksamer Pathotyp. Zeitschrift für Angewandte Entomologie, 96(1-5), 500-508. doi: 10.1111/j.14390418.1983.tb03704.x

KRIEGER, E., JOO, K., LEE, J., RAMAN, S., THOMPSON, J., TYKA, M., ... KARPLUS, K. (2009). Improving physical realism, stereochemistry, and side-chain accuracy in homology modeling: Four approaches that performed well in CASP8. [Research Support, N.I.H., Extramural]. Proteins, 77 Suppl 9, 114-122. doi: 10.1002/prot.22570

KRISHNAN, V. (2013). Investigation of parasporins, the cytotoxic proteins from the bacterium Bacillus thuringiensis. University of Sussex. Retrieved from http://sro.sussex.ac.uk/

KRONSTAD, J.W., SCHNEPF, H.E., \& WHITELEY, H.R. (1983). Diversity of Locations for BacillusThuringiensis Crystal Protein Genes. J Bacteriol, 154(1), 419-428.

KUMAR, S., \& NUSSINOV, R. (2002). Close-range electrostatic interactions in proteins. [Research Support, Non-U.S. Gov't Research Support, U.S. Gov't, P.H.S. Review]. Chembiochem, 3(7), 604-617. doi: 10.1002/1439-7633(20020703)3:7<604::AIDCBIC604>3.0.CO;2-X

KUNTZ, I.D., BLANEY, J.M., OATLEY, S.J., LANGRIDGE, R., \& FERRIN, T.E. (1982). A geometric approach to macromolecule-ligand interactions. [Research Support, Non-U.S. Gov't Research Support, U.S. Gov't, P.H.S.]. J Mol Biol, 161(2), 269-288.

KUO, W.S., \& CHAK, K.F. (1996). Identification of novel cry-type genes from Bacillus thuringiensis strains on the basis of restriction fragment length polymorphism of the PCR-amplified DNA. [Research Support, Non-U.S. Gov't]. Appl Environ Microbiol, 62(4), 1369-1377.

KUTZNER, C., CZUB, J., \& GRUBMULLER, H. (2011). Keep It Flexible: Driving Macromolecular Rotary Motions in Atomistic Simulations with GROMACS. J Chem Theory Comput, 7(5), 1381-1393. doi: 10.1021/ct100666v

KYSILKA, J., \& VONDRASEK, J. (2012). Towards a better understanding of the specificity of protein-protein interaction. [Research Support, Non-U.S. Gov't]. J Mol Recognit, 25(11), 604-615. doi: 10.1002/jmr.2219

LABBY, K.J. (2013). Protein visualization workshop: Interactive biochemistry using PyMOL and the PDB. Abstracts of Papers of the American Chemical Society, 246.

LAWO, N.C., WACKERS, F.L., \& ROMEIS, J. (2009). Indian Bt Cotton Varieties Do Not Affect the Performance of Cotton Aphids. PLoS One, 4(3). doi: Artn E4804 Doi 10.1371/Journal.Pone.0004804 
LECHNER, M., KUPKE, T., STEFANOVIC, S., \& GOTZ, F. (1989). Molecular characterization and sequence of phosphatidylinositol-specific phospholipase $C$ of Bacillus thuringiensis. [Research Support, Non-U.S. Gov't]. Mol Microbiol, 3(5), 621-626.

LERECLUS, D., \& AGAISSE, H. (2000). Toxin and virulence gene expression in Bacillus thuringiensis. In J.-F. Charles, A. Delécluse \& C.-L. Roux (Eds.), Entomopathogenic Bacteria: from Laboratory to Field Application (pp. 127-142): Springer Netherlands.

LERECLUS, D., AGAISSE, H., GOMINET, M., \& CHAUFAUX, J. (1995). Overproduction of encapsulated insecticidal crystal proteins in a Bacillus thuringiensis spo0A mutant. [Research Support, Non-U.S. Gov't]. Biotechnology (N Y), 13(1), 67-71.

LERECLUS, D., AGAISSE, H., GRANDVALET, C., SALAMITOU, S., \& GOMINET, M. (2000). Regulation of toxin and virulence gene transcription in Bacillus thuringiensis. [Review]. Int J Med Microbiol, 290(4-5), 295-299. doi: 10.1016/S1438-4221(00)80024-7

LEVINSON, B.L., KASYAN, K.J., CHIU, S.S., CURRIER, T.C., \& GONZALEZ, J.M., JR. (1990). Identification of beta-exotoxin production, plasmids encoding beta-exotoxin, and a new exotoxin in Bacillus thuringiensis by using high-performance liquid chromatography. J Bacteriol, 172(6), 3172-3179.

LI, J.D., CARROLL, J., \& ELLAR, D.J. (1991). Crystal structure of insecticidal delta-endotoxin from Bacillus thuringiensis at 2.5 A resolution. [Research Support, Non-U.S. Gov't]. Nature, 353(6347), 815-821. doi: 10.1038/353815a0

LIGHTWOOD, D.J., ELLAR, D.J., \& JARRETT, P. (2000). Role of proteolysis in determining potency of Bacillus thuringiensis Cry1Ac delta-endotoxin. [Comparative Study Research Support, Non-U.S. Gov't]. Appl Environ Microbiol, 66(12), 5174-5181.

LINDAHL, E. (2008). Molecular Dynamics Simulations. In A. Kukol (Ed.), Molecular Modeling of Proteins (Vol. 443, pp. 3-23): Humana Press.

LOEZA-LARA, P.D., BENINTENDE, G., COZZI, J., OCHOA-ZARZOSA, A., BAIZABAL-AGUIRRE, V.M., VALDEZ-ALARCON, J.J., \& LOPEZ-MEZA, J.E. (2005). The plasmid pBMBt1 from Bacillus thuringiensis subsp. darmstadiensis (INTA Mo14-4) replicates by the rolling-circle mechanism and encodes a novel insecticidal crystal protein-like gene. [Comparative Study Research Support, Non-U.S. Gov't]. Plasmid, 54(3), 229-240. doi: 10.1016/j.plasmid.2005.04.003

LOPEZ-PAZOS, S.A., CORTAZAR GOMEZ, J.E., \& CERON SALAMANCA, J.A. (2009). Cry1B and Cry3 $A$ are active against Hypothenemus hampei Ferrari (Coleoptera: Scolytidae). J Invertebr Pathol, 101(3), 242-245. doi: 10.1016/j.jip.2009.05.011

LOVELL, S.C., DAVIS, I.W., ARENDALL, W.B., 3RD, DE BAKKER, P.I., WORD, J.M., PRISANT, M.G., . .. RICHARDSON, D.C. (2003). Structure validation by Calpha geometry: phi, psi and Cbeta deviation. [Research Support, Non-U.S. Gov't Research Support, U.S. Gov't, P.H.S. Validation Studies]. Proteins, 50(3), 437-450. doi: 10.1002/prot.10286

LOVGREN, A., ZHANG, M., ENGSTROM, A., DALHAMMAR, G., \& LANDEN, R. (1990). Molecular characterization of immune inhibitor $A$, a secreted virulence protease from Bacillus thuringiensis. [Research Support, Non-U.S. Gov't]. Mol Microbiol, 4(12), 2137-2146.

LU, Y.H., WU, K.M., JIANG, Y.Y., XIA, B., LI, P., FENG, H.Q., . . GUO, Y.Y. (2010). Mirid Bug Outbreaks in Multiple Crops Correlated with Wide-Scale Adoption of Bt Cotton in China. Science, 328(5982), 1151-1154. doi: DOI 10.1126/science.1187881

LUCENA, W.A. (2012). Modelagem Molecular das $\delta$-endotoxinas doBacillus thuringiensis. Universidade Federal do Rio Grande do Sul.

LUCENA, W.A., PELEGRINI, P.B., MARTINS-DE-SA, D., FONSECA, F.C., GOMES, J.E., JR., DE MACEDO, L.L., ... GROSSI-DE-SA, M.F. (2014). Molecular approaches to improve the insecticidal activity of Bacillus thuringiensis Cry toxins. [Research Support, Non-U.S. Gov't]. Toxins (Basel), 6(8), 2393-2423. doi: 10.3390/toxins6082393 
LUO, K., SANGADALA, S., MASSON, L., MAZZA, A., BROUSSEAU, R., \& ADANG, M.J. (1997). The heliothis virescens $170 \mathrm{kDa}$ aminopeptidase functions as "receptor $\mathrm{A}$ " by mediating specific Bacillus thuringiensis Cry1A delta-endotoxin binding and pore formation. [Research Support, U.S. Gov't, Non-P.H.S.]. Insect Biochem Mol Biol, 27(8-9), 735-743.

MACKERELL, A.D., BASHFORD, D., BELLOTT, M., DUNBRACK, R.L., EVANSECK, J.D., FIELD, M.J., . .. KARPLUS, M. (1998). All-atom empirical potential for molecular modeling and dynamics studies of proteins. J Phys Chem B, 102(18), 3586-3616. doi: 10.1021/jp973084f

MAHILLON, J., REZSOHAZY, R., HALLET, B., \& DELCOUR, J. (1994). IS231 and other Bacillus thuringiensis transposable elements: a review. [Comparative Study Research Support, Non-U.S. Gov't Review]. Genetica, 93(1-3), 13-26.

MALVAR, T., \& BAUM, J.A. (1994). Tn5401 disruption of the spo0F gene, identified by direct chromosomal sequencing, results in CryllIA overproduction in Bacillus thuringiensis. $J$ Bacteriol, 176(15), 4750-4753.

MARROQUIN, L.D., ELYASSNIA, D., GRIFFITTS, J.S., FEITELSON, J.S., \& AROIAN, R.V. (2000). Bacillus thuringiensis $(\mathrm{Bt})$ toxin susceptibility and isolation of resistance mutants in the nematode Caenorhabditis elegans. [Research Support, U.S. Gov't, Non-P.H.S.]. Genetics, 155(4), 1693-1699.

MARTIN, P.A., \& TRAVERS, R.S. (1989). Worldwide Abundance and Distribution of Bacillus thuringiensis Isolates. Appl Environ Microbiol, 55(10), 2437-2442.

MARTINS, E.S., AGUIAR, R.W., MARTINS, N.F., MELATTI, V.M., FALCAO, R., GOMES, A.C., . . MONNERAT, R.G. (2008). Recombinant Cry1la protein is highly toxic to cotton boll weevil (Anthonomus grandis Boheman) and fall armyworm (Spodoptera frugiperda). [Research Support, Non-U.S. Gov't]. J Appl Microbiol, 104(5), 1363-1371. doi: 10.1111/j.1365-2672.2007.03665.x

MATHY, N., BÉNARD, L., PELLEGRINI, O., DAOU, R., WEN, T., \& CONDON, C. 5'-to-3' Exoribonuclease Activity in Bacteria: Role of RNase J1 in rRNA Maturation and 5' Stability of mRNA. Cell, 129(4), 681-692. doi: 10.1016/j.cell.2007.02.051

MATTES, O. (1927). Parasitre Kranheiten der Mehlmottenlaven und Versuche ber ihre Verwendbarkeit als biologiches. Gesamte Naturwiss, v.62, p.381-417.

MCBRIDE, K.E., SVAB, Z., SCHAAF, D.J., HOGAN, P.S., STALKER, D.M., \& MALIGA, P. (1995). Amplification of a chimeric Bacillus gene in chloroplasts leads to an extraordinary level of an insecticidal protein in tobacco. Biotechnology ( $N$ Y), 13(4), 362-365.

MCNALL, R.J., \& ADANG, M.J. (2003). Identification of novel Bacillus thuringiensis Cry1Ac binding proteins in Manduca sexta midgut through proteomic analysis. [Research Support, U.S. Gov't, Non-P.H.S. Research Support, U.S. Gov't, P.H.S.]. Insect Biochem Mol Biol, 33(10), 999-1010.

MENG, X.Y., ZHANG, H.X., MEZEI, M., \& CUI, M. (2011). Molecular docking: a powerful approach for structure-based drug discovery. [Research Support, N.I.H., Extramural Research Support, Non-U.S. Gov't Review]. Curr Comput Aided Drug Des, 7(2), 146-157.

MESRATI, L.A., TOUNSI, S., \& JAOUA, S. (2005). Characterization of a novel vip3-type gene from Bacillus thuringiensis and evidence of its presence on a large plasmid. [Research Support, Non-U.S. Gov't]. FEMS Microbiol Lett, 244(2), 353-358. doi: 10.1016/j.femsle.2005.02.007

MILNER, R.J. (1994). History of Bacillus thuringiensis. Agriculture, Ecosystems \& Environment, 49(1), 9-13. doi: http://dx.doi.org/10.1016/0167-8809(94)90014-0

MIRANDA, R., ZAMUDIO, F.Z., \& BRAVO, A. (2001). Processing of Cry1Ab delta-endotoxin from Bacillus thuringiensis by Manduca sexta and Spodoptera frugiperda midgut proteases: 
role in protoxin activation and toxin inactivation. [Research Support, Non-U.S. Gov't]. Insect Biochem Mol Biol, 31(12), 1155-1163.

MOHD-SALLEH, M.B., BEEGLE, C.C., \& LEWIS, L.C. (1980). Fermentation media and production of exotoxin by three varieties of Bacillus thuringiensis. J Invertebr Pathol, 35(1), 75-83. doi: http://dx.doi.org/10.1016/0022-2011(80)90086-5

MOLLE, V., FUJITA, M., JENSEN, S.T., EICHENBERGER, P., GONZALEZ-PASTOR, J.E., LIU, J.S., \& LOSICK, R. (2003). The SpoOA regulon of Bacillus subtilis. [Research Support, Non-U.S. Gov't Research Support, U.S. Gov't, Non-P.H.S. Research Support, U.S. Gov't, P.H.S.]. Mol Microbiol, 50(5), 1683-1701.

MORRIS, G., \& LIM-WILBY, M. (2008). Molecular Docking. In A. Kukol (Ed.), Molecular Modeling of Proteins (Vol. 443, pp. 365-382): Humana Press.

MORSE, R.J., YAMAMOTO, T., \& STROUD, R.M. (2001). Structure of Cry2Aa suggests an unexpected receptor binding epitope. [Research Support, U.S. Gov't, Non-P.H.S. Research Support, U.S. Gov't, P.H.S.]. Structure, 9(5), 409-417.

MURAWSKA, E., FIEDORUK, K., \& SWIECICKA, I. (2014). Modular genetic architecture of the toxigenic plasmid pIS56-63 harboring cry1Ab21 in Bacillus thuringiensis subsp. thuringiensis strain IS5056. [Research Support, Non-U.S. Gov't]. Pol J Microbiol, 63(2), 147-156.

NAGAMATSU, Y., KOIKE, T., SASAKI, K., YOSHIMOTO, A., \& FURUKAWA, Y. (1999). The cadherin-like protein is essential to specificity determination and cytotoxic action of the Bacillus thuringiensis insecticidal CrylAa toxin. FEBS Lett, 460(2), 385-390. doi: http://dx.doi.org/10.1016/S0014-5793(99)01327-7

NAGAR, B., OVERDUIN, M., IKURA, M., \& RINI, J.M. (1996). Structural basis of calcium-induced E-cadherin rigidification and dimerization. [Research Support, U.S. Gov't, P.H.S.]. Nature, 380(6572), 360-364. doi: 10.1038/380360a0

NGAMWONGSATIT, P., BUASRI, W., PIANARIYANON, P., PULSRIKARN, C., OHBA, M., ASSAVANIG, A., \& PANBANGRED, W. (2008). Broad distribution of enterotoxin genes (hbICDA, nheABC, cytK, and entFM) among Bacillus thuringiensis and Bacillus cereus as shown by novel primers. [Research Support, Non-U.S. Gov't]. Int J Food Microbiol, 121(3), 352-356. doi: 10.1016/j.ijfoodmicro.2007.11.013

NI, H., ZENG, S., QIN, X., SUN, X., ZHANG, S., ZHAO, X., . . LI, L. (2015). Molecular Docking and Site-directed Mutagenesis of a Bacillus thuringiensis Chitinase to Improve Chitinolytic, Synergistic Lepidopteran-larvicidal and Nematicidal Activities. Int J Biol Sci, 11(3), 304315. doi: 10.7150/ijbs.10632

OCHOA-CAMPUZANO, C., REAL, M.D., MARTÍNEZ-RAMÍREZ, A.C., BRAVO, A., \& RAUSELL, C. (2007). An ADAM metalloprotease is a Cry3Aa Bacillus thuringiensis toxin receptor. Biochem Biophys Res Commun, 362(2), 437-442. doi: http://dx.doi.org/10.1016/j.bbrc.2007.07.197

OHBA, M., MIZUKI, E., \& UEMORI, A. (2009). Parasporin, a new anticancer protein group from Bacillus thuringiensis. [Review]. Anticancer Res, 29(1), 427-433.

OPPERT, B., KRAMER, K.J., BEEMAN, R.W., JOHNSON, D., \& MCGAUGHEY, W.H. (1997). Proteinase-mediated insect resistance to Bacillus thuringiensis toxins. $J$ Biol Chem, 272(38), 23473-23476.

PACHECO, S., GOMEZ, I., ARENAS, I., SAAB-RINCON, G., RODRIGUEZ-ALMAZAN, C., GILL, S.S., . . . SOBERON, M. (2009). Domain II loop 3 of Bacillus thuringiensis Cry1Ab toxin is involved in a "ping pong" binding mechanism with Manduca sexta aminopeptidase- $\mathrm{N}$ and cadherin receptors. [Research Support, N.I.H., Extramural Research Support, NonU.S. Gov't Research Support, U.S. Gov't, Non-P.H.S.]. J Biol Chem, 284(47), 3275032757. doi: 10.1074/jbc.M109.024968 
PALLEN, M.J. (2002). The ESAT-6/WXG100 superfamily -- and a new Gram-positive secretion system? [Comparative Study]. Trends Microbiol, 10(5), 209-212.

PALMA, L., MUNOZ, D., BERRY, C., MURILLO, J., \& CABALLERO, P. (2014). Bacillus thuringiensis toxins: an overview of their biocidal activity. [Research Support, Non-U.S. Gov't Review]. Toxins (Basel), 6(12), 3296-3325. doi: 10.3390/toxins6123296

PALMA, L., MUNOZ, D., MURILLO, J., \& CABALLERO, P. (2014). Draft Genome Sequence of Bacillus thuringiensis Serovar Tolworthi Strain Na205-3, an Isolate Toxic for Helicoverpa armigera. Genome Announc, 2(2). doi: 10.1128/genomeA.00187-14

PARDO-LOPEZ, L., MUNOZ-GARAY, C., PORTA, H., RODRIGUEZ-ALMAZAN, C., SOBERON, M., \& BRAVO, A. (2009). Strategies to improve the insecticidal activity of Cry toxins from Bacillus thuringiensis. [Research Support, N.I.H., Extramural Research Support, NonU.S. Gov't Research Support, U.S. Gov't, Non-P.H.S. Review]. Peptides, 30(3), 589-595. doi: 10.1016/j.peptides.2008.07.027

PARK, H.W., BIDESHI, D.K., \& FEDERICI, B.A. (2000). Molecular genetic manipulation of truncated Cry1C protein synthesis in Bacillus thuringiensis to improve stability and yield. [Research Support, Non-U.S. Gov't]. Appl Environ Microbiol, 66(10), 4449-4455.

PAULA, D.P., ANDOW, D.A., TIMBO, R.V., SUJII, E.R., PIRES, C.S., \& FONTES, E.M. (2014). Uptake and transfer of a Bt toxin by a Lepidoptera to its eggs and effects on its offspring. [Research Support, Non-U.S. Gov't]. PLoS One, 9(4), e95422. doi: 10.1371/journal.pone.0095422

PENDLETON, I.R., BERNHEIMER, A.W., \& GRUSHOFF, P. (1973). Purification and partial characterization of hemolysins from Bacillus thuringiensis. J Invertebr Pathol, 21(2), 131-135.

PENG, D., XU, X., RUAN, L., YU, Z., \& SUN, M. (2010). Enhancing Cry1Ac toxicity by expression of the Helicoverpa armigera cadherin fragment in Bacillus thuringiensis. [Research Support, Non-U.S. Gov't]. Res Microbiol, 161(5), 383-389. doi: 10.1016/j.resmic.2010.04.004

PENG, D., XU, X., YE, W., YU, Z., \& SUN, M. (2010). Helicoverpa armigera cadherin fragment enhances Cry1Ac insecticidal activity by facilitating toxin-oligomer formation. [Research Support, Non-U.S. Gov't]. Appl Microbiol Biotechnol, 85(4), 1033-1040. doi: 10.1007/s00253-009-2142-1

PERANI, M., BISHOP, A.H., \& VAID, A. (1998). Prevalence of beta-exotoxin, diarrhoeal toxin and specific delta-endotoxin in natural isolates of Bacillus thuringiensis. [Research Support, Non-U.S. Gov't]. FEMS Microbiol Lett, 160(1), 55-60.

PÉREZ-GARCÍA, G., BASURTO-RÍOS, R., \& IBARRA, J.E. (2010). Potential effect of a putative $\sigma H$ driven promoter on the over expression of the Cry1Ac toxin of Bacillus thuringiensis. $J$ Invertebr Pathol, 104(2), 140-146. doi: http://dx.doi.org/10.1016/j.jip.2010.02.010

PEREZ, C., FERNANDEZ, L.E., SUN, J., FOLCH, J.L., GILL, S.S., SOBERON, M., \& BRAVO, A. (2005). Bacillus thuringiensis subsp. israelensis Cyt1Aa synergizes Cry11Aa toxin by functioning as a membrane-bound receptor. [Research Support, N.I.H., Extramural Research Support, Non-U.S. Gov't Research Support, U.S. Gov't, Non-P.H.S.]. Proc Natl Acad Sci U S A, 102(51), 18303-18308. doi: 10.1073/pnas.0505494102

PEREZ, T.D., \& NELSON, W.J. (2004). Cadherin adhesion: mechanisms and molecular interactions. Handb Exp Pharmacol(165), 3-21. doi: 10.1007/978-3-540-68170-0_1

PERLAK, F.J., FUCHS, R.L., DEAN, D.A., MCPHERSON, S.L., \& FISCHHOFF, D.A. (1991). Modification of the coding sequence enhances plant expression of insect control protein genes. Proc Natl Acad Sci U S A, 88(8), 3324-3328. 
PERLAK, F.J., STONE, T.B., MUSKOPF, Y.M., PETERSEN, L.J., PARKER, G.B., MCPHERSON, S.A., . . ET AL. (1993). Genetically improved potatoes: protection from damage by Colorado potato beetles. Plant Mol Biol, 22(2), 313-321.

PETTITT, J. (2005). The cadherin superfamily. [Review]. WormBook, 1-9. doi: 10.1895/wormbook.1.50.1

PIGGOT, P.J., \& HILBERT, D.W. (2004). Sporulation of Bacillus subtilis. [Research Support, U.S. Gov't, Non-P.H.S. Research Support, U.S. Gov't, P.H.S. Review]. Curr Opin Microbiol, 7(6), 579-586. doi: 10.1016/j.mib.2004.10.001

PIGOTT, C.R., \& ELLAR, D.J. (2007). Role of receptors in Bacillus thuringiensis crystal toxin activity. [Review]. Microbiol Mol Biol Rev, 71(2), 255-281. doi: 10.1128/MMBR.0003406

PONCET, S., DERVYN, E., KLIER, A., \& RAPOPORT, G. (1997). SpoOA represses transcription of the cry toxin genes in Bacillus thuringiensis. [Comparative Study Research Support, Non-U.S. Gov't]. Microbiology, 143 ( Pt 8), 2743-2751.

POPOFF, M.R. (2011). Epsilon toxin: a fascinating pore-forming toxin. [Review]. FEBS J, 278(23), 4602-4615. doi: 10.1111/j.1742-4658.2011.08145.x

PORCAR, M., \& JUAREZ-PEREZ, V. (2003). PCR-based identification of Bacillus thuringiensis pesticidal crystal genes. [Comparative Study Review]. FEMS Microbiol Rev, 26(5), 419432.

PRAY, C.E., HUANG, J., HU, R., \& ROZELLE, S. (2002). Five years of Bt cotton in China - the benefits continue. [Comparative Study Research Support, Non-U.S. Gov't Review]. Plant J, 31(4), 423-430.

PRONK, S., PALL, S., SCHULZ, R., LARSSON, P., BJELKMAR, P., APOSTOLOV, R., . . LINDAHL, E. (2013). GROMACS 4.5: a high-throughput and highly parallel open source molecular simulation toolkit. [Research Support, N.I.H., Extramural Research Support, Non-U.S. Gov't]. Bioinformatics, 29(7), 845-854. doi: 10.1093/bioinformatics/btt055

RAJAMOHAN, F., ALCANTARA, E., LEE, M.K., CHEN, X.J., CURTISS, A., \& DEAN, D.H. (1995). Single amino acid changes in domain II of Bacillus thuringiensis CrylAb delta-endotoxin affect irreversible binding to Manduca sexta midgut membrane vesicles. [Comparative Study Research Support, Non-U.S. Gov't Research Support, U.S. Gov't, P.H.S.]. J Bacteriol, 177(9), 2276-2282.

RAJAMOHAN, F., ALZATE, O., COTRILL, J.A., CURTISS, A., \& DEAN, D.H. (1996). Protein engineering of Bacillus thuringiensis delta-endotoxin: mutations at domain II of CrylAb enhance receptor affinity and toxicity toward gypsy moth larvae. [Research Support, Non-U.S. Gov't Research Support, U.S. Gov't, P.H.S.]. Proc Natl Acad Sci U S A, 93(25), 14338-14343.

RAJAMOHAN, F., HUSSAIN, S.R., COTRILL, J.A., GOULD, F., \& DEAN, D.H. (1996). Mutations at domain II, loop 3, of Bacillus thuringiensis CrylAa and CrylAb delta-endotoxins suggest loop 3 is involved in initial binding to lepidopteran midguts. [Research Support, U.S. Gov't, P.H.S.]. J Biol Chem, 271(41), 25220-25226.

RAJAMOHAN, F., LEE, M.K., \& DEAN, D.H. (1998). Bacillus thuringiensis insecticidal proteins: molecular mode of action. [Review]. Prog Nucleic Acid Res Mol Biol, 60, 1-27.

RAYMOND, B., JOHNSTON, P.R., NIELSEN-LEROUX, C., LERECLUS, D., \& CRICKMORE, N. (2010). Bacillus thuringiensis: an impotent pathogen? Trends Microbiol, 18(5), 189-194. doi: 10.1016/j.tim.2010.02.006 
REED, G.L., JENSEN, A.S., RIEBE, J., HEAD, G., \& DUAN, J.J. (2001). Transgenic Bt potato and conventional insecticides for Colorado potato beetle management: comparative efficacy and non-target impacts. Entomologia Experimentalis Et Applicata, 100(1), 89100. doi: DOI 10.1046/j.1570-7458.2001.00851.x

RIGDEN, D.J. (2009). Does distant homology with Evf reveal a lipid binding site in Bacillus thuringiensis cytolytic toxins? FEBS Lett, 583(10), 1555-1560. doi: http://dx.doi.org/10.1016/j.febslet.2009.04.038

RODRIGUES, J.P., LEVITT, M., \& CHOPRA, G. (2012). KoBaMIN: a knowledge-based minimization web server for protein structure refinement. [Research Support, N.I.H., Extramural]. Nucleic Acids Res, 40(Web Server issue), W323-328. doi: 10.1093/nar/gks376

ROSENQUIST, H., SMIDT, L., ANDERSEN, S.R., JENSEN, G.B., \& WILCKS, A. (2005). Occurrence and significance of Bacillus cereus and Bacillus thuringiensis in ready-to-eat food. FEMS Microbiol Lett, 250(1), 129-136. doi: DOI 10.1016/j.femsle.2005.06.054

RUIZ DE ESCUDERO, I., ESTELA, A., PORCAR, M., MARTINEZ, C., OGUIZA, J.A., ESCRICHE, B., . . CABALLERO, P. (2006). Molecular and insecticidal characterization of a Cry1l protein toxic to insects of the families Noctuidae, Tortricidae, Plutellidae, and Chrysomelidae. [Research Support, Non-U.S. Gov't]. Appl Environ Microbiol, 72(7), 4796-4804. doi: 10.1128/AEM.02861-05

SACHETT, L. (2014). Introdução de Informação Sacarídica em Estruturas Cristalinas e sua Implicação no Entendimento de Processos Patológicos. PhD, Universidade Ferderal do Rio Grande do Sul.

SALAMITOU, S., RAMISSE, F., BREHÉLIN, M., BOURGUET, D., GILOIS, N., GOMINET, M., . . LERECLUS, D. (2000). The plcR regulon is involved in the opportunistic properties of Bacillus thuringiensis and Bacillus cereus in mice and insects. Microbiology, 146(11), 2825-2832.

SANAHUJA, G., BANAKAR, R., TWYMAN, R.M., CAPELL, T., \& CHRISTOU, P. (2011). Bacillus thuringiensis: a century of research, development and commercial applications. [Research Support, Non-U.S. Gov't Review]. Plant Biotechnol J, 9(3), 283-300. doi: 10.1111/j.1467-7652.2011.00595.x

SANGADALA, S., WALTERS, F.S., ENGLISH, L.H., \& ADANG, M.J. (1994). A mixture of Manduca sexta aminopeptidase and phosphatase enhances Bacillus thuringiensis insecticidal CrylA(c) toxin binding and 86Rb(+)-K+ efflux in vitro. [Research Support, Non-U.S. Gov't]. J Biol Chem, 269(13), 10088-10092.

SATTAR, S., \& MAITI, M.K. (2011). Molecular characterization of a novel vegetative insecticidal protein from Bacillus thuringiensis effective against sap-sucking insect pest. [Research Support, Non-U.S. Gov't]. J Microbiol Biotechnol, 21(9), 937-946.

SAWAYA, M.R., CASCIO, D., GINGERY, M., RODRIGUEZ, J., GOLDSCHMIDT, L., COLLETIER, J.P., . . . EISENBERG, D.S. (2014). Protein crystal structure obtained at 2.9 angstrom resolution from injecting bacterial cells into an X-ray free-electron laser beam. Proc Natl Acad Sci U S A, 111(35), 12769-12774. doi: DOI 10.1073/pnas.1413456111

SCHNEPF, E., CRICKMORE, N., VAN RIE, J., LERECLUS, D., BAUM, J., FEITELSON, J., . . DEAN, D.H. (1998). Bacillus thuringiensis and its pesticidal crystal proteins. [Research Support, U.S. Gov't, Non-P.H.S. Review]. Microbiol Mol Biol Rev, 62(3), 775-806.

SCHNEPF, H.E., \& WHITELEY, H.R. (1981). Cloning and expression of the Bacillus thuringiensis crystal protein gene in Escherichia coli. [Research Support, U.S. Gov't, P.H.S.]. Proc Natl Acad Sci U S A, 78(5), 2893-2897.

SHAO, Z., LIU, Z., \& YU, Z. (2001). Effects of the 20-kilodalton helper protein on Cry1AC production and spore formation in Bacillus thuringiensis. [Research Support, Non-U.S. 
Gov't]. Appl Environ Microbiol, 67(12), 5362-5369. doi: 10.1128/AEM.67.12.53625369.2001

SHI, Y., MA, W., YUAN, M., SUN, F., \& PANG, Y. (2007). 'Cloning of vip1/vip2 genes and expression of Vip1Ca/Vip2Ac proteins in Bacillus thuringiensis. World Journal of Microbiology and Biotechnology, 23(4), 501-507. doi: 10.1007/s11274-006-9252-z

SHI, Y., XU, W., YUAN, M., TANG, M., CHEN, J., \& PANG, Y. (2004). Expression of vip1/vip2 genes in Escherichia coli and Bacillus thuringiensis and the analysis of their signal peptides. [Comparative Study Research Support, Non-U.S. Gov't]. J Appl Microbiol, 97(4), 757-765. doi: 10.1111/j.1365-2672.2004.02365.x

SHORTLE, D., SIMONS, K.T., \& BAKER, D. (1998). Clustering of low-energy conformations near the native structures of small proteins. [Research Support, Non-U.S. Gov't Research Support, U.S. Gov't, Non-P.H.S. Research Support, U.S. Gov't, P.H.S.]. Proc Natl Acad Sci U S A, 95(19), 11158-11162.

SIEGEL, J.P. (2001). The mammalian safety of Bacillus thuringiensis-based insecticides. J Invertebr Pathol, 77(1), 13-21. doi: DOI 10.1006/jipa.2000.5000

SILO-SUH, L.A., STABB, E.V., RAFFEL, S.J., \& HANDELSMAN, J. (1998). Target range of zwittermicin A, an aminopolyol antibiotic from Bacillus cereus. [Research Support, Non-U.S. Gov't Research Support, U.S. Gov't, Non-P.H.S.]. Curr Microbiol, 37(1), 6-11.

SOBERON, M., LOPEZ-DIAZ, J.A., \& BRAVO, A. (2013). Cyt toxins produced by Bacillus thuringiensis: a protein fold conserved in several pathogenic microorganisms. [Research Support, Non-U.S. Gov't Review]. Peptides, 41, 87-93. doi: 10.1016/j.peptides.2012.05.023

SOTOMAYOR, M., \& SCHULTEN, K. (2008). The allosteric role of the Ca2+ switch in adhesion and elasticity of C-cadherin. [Research Support, N.I.H., Extramural Research Support, U.S. Gov't, Non-P.H.S.]. Biophys J, 94(12), 4621-4633. doi: 10.1529/biophysj.107.125591

SRISUCHARITPANIT, K., YAO, M., PROMDONKOY, B., CHIMNARONK, S., TANAKA, I., \& BOONSERM, P. (2014). Crystal structure of BinB: a receptor binding component of the binary toxin from Lysinibacillus sphaericus. [Research Support, Non-U.S. Gov't]. Proteins, 82(10), 2703-2712. doi: 10.1002/prot.24636

STABB, E.V., JACOBSON, L.M., \& HANDELSMAN, J. (1994). Zwittermicin A-producing strains of Bacillus cereus from diverse soils. [Research Support, Non-U.S. Gov't Research Support, U.S. Gov't, Non-P.H.S. Research Support, U.S. Gov't, P.H.S.]. Appl Environ Microbiol, 60(12), 4404-4412.

STAMM, M., STARITZBICHLER, R., KHAFIZOV, K., \& FORREST, L.R. (2014). AlignMe--a membrane protein sequence alignment web server. [Research Support, N.I.H., Intramural Research Support, Non-U.S. Gov't]. Nucleic Acids Res, 42(Web Server issue), W246251. doi: $10.1093 /$ nar/gku291

STAPLES, N., ELLAR, D., \& CRICKMORE, N. (2001). Cellular localization and characterization of the Bacillus thuringiensis Orf2 crystallization factor. [Research Support, Non-U.S. Gov't]. Curr Microbiol, 42(6), 388-392. doi: 10.1007/s002840010235

STEINHAUS, E.A. (1951). Possible Use of Bacillus thuringiensis Berliner as an Aid in the Biological Control of the Alfalfa Caterpillar. Hilgardia, 20(18), 359-381 pp.

STEPHENS, E., SUGARS, J., MASLEN, S.L., WILLIAMS, D.H., PACKMAN, L.C., \& ELLAR, D.J. (2004). The $\mathrm{N}$-linked oligosaccharides of aminopeptidase $\mathrm{N}$ from Manduca sexta: site 
localization and identification of novel N-glycan structures. [Research Support, NonU.S. Gov't]. Eur J Biochem, 271(21), 4241-4258. doi: 10.1111/j.1432-1033.2004.04364.x

SWIECICKA, I., VAN DER AUWERA, G.A., \& MAHILLON, J. (2006). Hemolytic and nonhemolytic enterotoxin genes are broadly distributed among Bacillus thuringiensis isolated from wild mammals. Microb Ecol, 52(3), 544-551. doi: 10.1007/s00248-006-9122-0

TABASHNIK, B.E., BREVAULT, T., \& CARRIERE, Y. (2013). Insect resistance to Bt crops: lessons from the first billion acres. [Research Support, U.S. Gov't, Non-P.H.S. Review]. Nat Biotechnol, 31(6), 510-521. doi: 10.1038/nbt.2597

TANAKA, S., MIYAMOTO, K., NODA, H., JURAT-FUENTES, J.L., YOSHIZAWA, Y., ENDO, H., \& SATO, R. (2013). The ATP-binding cassette transporter subfamily C member 2 in Bombyx mori larvae is a functional receptor for Cry toxins from Bacillus thuringiensis. [Research Support, Non-U.S. Gov't Research Support, U.S. Gov't, Non-P.H.S.]. FEBS J, 280(8), 1782-1794. doi: 10.1111/febs.12200

TANG, Y., ZOU, J., ZHANG, L., LI, Z., MA, C., \& MA, N. (2012). Anti-fungi activities of Bacillus thuringiensis $\mathrm{H} 3$ chitinase and immobilized chitinase particles and their effects to rice seedling defensive enzymes. [Research Support, Non-U.S. Gov't]. J Nanosci Nanotechnol, 12(10), 8081-8086.

TERRA, W.R., \& FERREIRA, C. (1994). Insect Digestive Enzymes - Properties, Compartmentalization and Function. Comparative Biochemistry and Physiology BBiochemistry \& Molecular Biology, 109(1), 1-62. doi: Doi 10.1016/03050491(94)90141-4

THOMAS, D.J.I., MORGAN, J.A.W., WHIPPS, J.M., \& SAUNDERS, J.R. (2000). Plasmid Transfer between the Bacillus thuringiensis Subspecies kurstaki and tenebrionis in Laboratory Culture and Soil and in Lepidopteran and Coleopteran Larvae. Appl Environ Microbiol, 66(1), 118-124.

THOMAS, D.J.I., MORGAN, J.A.W., WHIPPS, J.M., \& SAUNDERS, J.R. (2001). Plasmid Transfer between Bacillus thuringiensis subsp.israelensis Strains in Laboratory Culture, River Water, and Dipteran Larvae. Appl Environ Microbiol, 67(1), 330-338.

TSUDA, Y., NAKATANI, F., HASHIMOTO, K., IKAWA, S., MATSUURA, C., FUKADA, T., ... HIMENO, M. (2003). Cytotoxic activity of Bacillus thuringiensis Cry proteins on mammalian cells transfected with cadherin-like Cry receptor gene of Bombyx mori (silkworm). [Research Support, Non-U.S. Gov't]. Biochem J, 369(Pt 3), 697-703. doi: 10.1042/BJ20021401

VADLAMUDI, R.K., JI, T.H., \& BULLA, L.A., JR. (1993). A specific binding protein from Manduca sexta for the insecticidal toxin of Bacillus thuringiensis subsp. berliner. [Research Support, U.S. Gov't, Non-P.H.S.]. J Biol Chem, 268(17), 12334-12340.

VADLAMUDI, R.K., WEBER, E., JI, I., JI, T.H., \& BULLA, L.A., JR. (1995). Cloning and expression of a receptor for an insecticidal toxin of Bacillus thuringiensis. [Comparative Study Research Support, U.S. Gov't, Non-P.H.S. Research Support, U.S. Gov't, P.H.S.]. J Biol Chem, 270(10), 5490-5494.

VAECK, M., REYNAERTS, A., HOFTE, H., JANSENS, S., DE BEUCKELEER, M., DEAN, C., . . . LEEMANS, J. (1987). Transgenic plants protected from insect attack. [10.1038/328033a0]. Nature, 328(6125), 33-37.

VALAITIS, A.P., JENKINS, J.L., LEE, M.K., DEAN, D.H., \& GARNER, K.J. (2001). Isolation and partial characterization of gypsy moth BTR-270, an anionic brush border membrane glycoconjugate that binds Bacillus thuringiensis Cry1A toxins with high affinity. Arch Insect Biochem Physiol, 46(4), 186-200. doi: 10.1002/arch.1028

VALAITIS, A.P., LEE, M.K., RAJAMOHAN, F., \& DEAN, D.H. (1995). Brush border membrane aminopeptidase- $\mathrm{N}$ in the midgut of the gypsy moth serves as the receptor for the 
CrylA(c) delta-endotoxin of Bacillus thuringiensis. [Research Support, U.S. Gov't, NonP.H.S. Research Support, U.S. Gov't, P.H.S.]. Insect Biochem Mol Biol, 25(10), 11431151.

VAN FRANKENHUYZEN, K. (2009). Insecticidal activity of Bacillus thuringiensis crystal proteins. [Review]. J Invertebr Pathol, 101(1), 1-16. doi: 10.1016/j.jip.2009.02.009

VAN FRANKENHUYZEN, K. (2013). Cross-order and cross-phylum activity of Bacillus thuringiensis pesticidal proteins. [Review]. J Invertebr Pathol, 114(1), 76-85. doi: 10.1016/j.jip.2013.05.010

VAN RIE, J., JANSENS, S., HOFTE, H., DEGHEELE, D., \& VAN MELLAERT, H. (1990). Receptors on the brush border membrane of the insect midgut as determinants of the specificity of Bacillus thuringiensis delta-endotoxins. [Research Support, Non-U.S. Gov't]. Appl Environ Microbiol, 56(5), 1378-1385.

WANG, A., PATTEMORE, J., ASH, G., WILLIAMS, A., \& HANE, J. (2013). Draft genome sequence of Bacillus thuringiensis strain DAR 81934, which exhibits molluscicidal activity. Genome Announc, 1(2), e0017512. doi: 10.1128/genomeA.00175-12

WANG, J., MEI, H., QIAN, H., TANG, Q., LIU, X., YU, Z., \& HE, J. (2013). Expression profile and regulation of spore and parasporal crystal formation-associated genes in Bacillus thuringiensis. [Research Support, Non-U.S. Gov't]. J Proteome Res, 12(12), 5487-5501. doi: $10.1021 /$ pr4003728

WEBB, B., \& SALI, A. (2014a). Comparative Protein Structure Modeling Using MODELLER. Curr Protoc Bioinformatics, 47, 56 1-5 6 32. doi: 10.1002/0471250953.bi0506s47

WEBB, B., \& SALI, A. (2014b). Protein structure modeling with MODELLER. [Research Support, N.I.H., Extramural]. Methods Mol Biol, 1137, 1-15. doi: 10.1007/978-1-4939-0366-5_1

WIDNER, W.R., \& WHITELEY, H.R. (1989). Two highly related insecticidal crystal proteins of Bacillus thuringiensis subsp. kurstaki possess different host range specificities. [Comparative Study Research Support, U.S. Gov't, Non-P.H.S. Research Support, U.S. Gov't, P.H.S.]. J Bacteriol, 171(2), 965-974.

WIEDERSTEIN, M., \& SIPPL, M.J. (2007). ProSA-web: interactive web service for the recognition of errors in three-dimensional structures of proteins. [Research Support, Non-U.S. Gov't]. Nucleic Acids Res, 35(Web Server issue), W407-410. doi: 10.1093/nar/gkm290

WONG, H.C., \& CHANG, S. (1986). Identification of a positive retroregulator that stabilizes mRNAs in bacteria. Proc Natl Acad Sci U S A, 83(10), 3233-3237.

WU, J., ZHAO, F., BAI, J., DENG, G., QIN, S., \& BAO, Q. (2007). Evidence for positive Darwinian selection of Vip gene in Bacillus thuringiensis. [Research Support, Non-U.S. Gov't]. J Genet Genomics, 34(7), 649-660. doi: 10.1016/S1673-8527(07)60074-5

WU, J.Y., ZHAO, F.Q., BAI, J., DENG, G., QIN, S., \& BAO, Q.Y. (2007). Adaptive evolution of cry genes in Bacillus thuringiensis: implications for their specificity determination. [Research Support, Non-U.S. Gov't]. Genomics Proteomics Bioinformatics, 5(2), $102-$ 110. doi: 10.1016/S1672-0229(07)60020-5

WU, S., \& ZHANG, Y. (2007). LOMETS: a local meta-threading-server for protein structure prediction. [Evaluation Studies Research Support, Non-U.S. Gov't]. Nucleic Acids Res, 35(10), 3375-3382. doi: 10.1093/nar/gkm251

XIE, R., ZHUANG, M., ROSS, L.S., GOMEZ, I., OLTEAN, D.I., BRAVO, A., . . GILL, S.S. (2005). Single amino acid mutations in the cadherin receptor from Heliothis virescens affect its toxin binding ability to Cry1A toxins. [Research Support, Non-U.S. Gov't Research Support, U.S. Gov't, Non-P.H.S.]. J Biol Chem, 280(9), 8416-8425. doi: 10.1074/jbc.M408403200 
XU, C., WANG, B.C., YU, Z., \& SUN, M. (2014). Structural insights into Bacillus thuringiensis Cry, Cyt and parasporin toxins. [Research Support, Non-U.S. Gov't]. Toxins (Basel), 6(9), 2732-2770. doi: 10.3390/toxins6092732

XU, D., \& ZHANG, Y. (2011). Improving the physical realism and structural accuracy of protein models by a two-step atomic-level energy minimization. [Research Support, N.I.H., Extramural Research Support, U.S. Gov't, Non-P.H.S.]. Biophys J, 101(10), 2525-2534. doi: 10.1016/j.bpj.2011.10.024

XU, D., \& ZHANG, Y. (2012). Ab initio protein structure assembly using continuous structure fragments and optimized knowledge-based force field. Proteins: Structure, Function, and Bioinformatics, 80(7), 1715-1735. doi: 10.1002/prot.24065

XU, Y., NAGAI, M., BAGDASARIAN, M., SMITH, T.W., \& WALKER, E.D. (2001). Expression of the p20 gene from Bacillus thuringiensis $\mathrm{H}-14$ increases Cry11A toxin production and enhances mosquito-larvicidal activity in recombinant gram-negative bacteria. [Research Support, U.S. Gov't, P.H.S.]. Appl Environ Microbiol, 67(7), 3010-3015. doi: 10.1128/AEM.67.7.3010-3015.2001

XUE, Z., XU, D., WANG, Y., \& ZHANG, Y. (2013). ThreaDom: extracting protein domain boundary information from multiple threading alignments. [Research Support, N.I.H., Extramural Research Support, Non-U.S. Gov't Research Support, U.S. Gov't, NonP.H.S.]. Bioinformatics, 29(13), i247-256. doi: 10.1093/bioinformatics/btt209

YANG, H., WANG, P., PENG, Q., RONG, R., LIU, C., LERECLUS, D., ... HUANG, D. (2012). Weak transcription of the cry1Ac gene in nonsporulating Bacillus thuringiensis cells. [Research Support, Non-U.S. Gov't]. Appl Environ Microbiol, 78(18), 6466-6474. doi: 10.1128/AEM.01229-12

YOKOYAMA, T., TANAKA, M., \& HASEGAWA, M. (2004). Novel cry gene from Paenibacillus lentimorbus strain Semadara inhibits ingestion and promotes insecticidal activity in Anomala cuprea larvae. [Comparative Study]. J Invertebr Pathol, 85(1), 25-32. doi: 10.1016/j.jip.2003.12.009

YOSHISUE, H., IHARA, K., NISHIMOTO, T., SAKAI, H., \& KOMANO, T. (1995). Expression of the genes for insecticidal crystal proteins in Bacillus thuringiensis: cryIVA, not crylVB, is transcribed by RNA polymerase containing sigma $\mathrm{H}$ and that containing sigma $\mathrm{E}$. [Comparative Study]. FEMS Microbiol Lett, 127(1-2), 65-72.

YU, X., LIU, T., SUN, Z., GUAN, P., ZHU, J., WANG, S., . . LI, P. (2012). Co-expression and synergism analysis of Vip3Aa29 and Cyt2Aa3 insecticidal proteins from Bacillus thuringiensis. [Research Support, Non-U.S. Gov't]. Curr Microbiol, 64(4), 326-331. doi: 10.1007/s00284-011-0070-7

YU, Z., LUO, H., XIONG, J., ZHOU, Q., XIA, L., SUN, M., \& LI, L. (2014). Bacillus thuringiensis Cry6A exhibits nematicidal activity to Caenorhabditis elegans bre mutants and synergistic activity with Cry5B to C. elegans. [Research Support, N.I.H., Extramural Research Support, Non-U.S. Gov't]. Lett Appl Microbiol, 58(6), 511-519. doi: 10.1111/lam.12219

ZEILINGER, A.R., ANDOW, D.A., ZWAHLEN, C., \& STOTZKY, G. (2010). Earthworm populations in a northern US Cornbelt soil are not affected by long-term cultivation of Bt maize expressing Cry1Ab and Cry3Bb1 proteins. Soil Biology \& Biochemistry, 42(8), 12841292. doi: DOI 10.1016/j.soilbio.2010.04.004

ZHANG, B., LIU, M., YANG, Y., \& YUAN, Z. (2006). Cytolytic toxin Cyt1Aa of Bacillus thuringiensis synergizes the mosquitocidal toxin Mtx1 of Bacillus sphaericus. [Research Support, Non-U.S. Gov't]. Biosci Biotechnol Biochem, 70(9), 2199-2204. doi: 10.1271/bbb.60140 
ZHANG, J., HODGMAN, T.C., KRIEGER, L., SCHNETTER, W., \& SCHAIRER, H.U. (1997). Cloning and analysis of the first cry gene from Bacillus popilliae. [Research Support, Non-U.S. Gov't]. J Bacteriol, 179(13), 4336-4341.

ZHANG, J., SCHAIRER, H.U., SCHNETTER, W., LERECLUS, D., \& AGAISSE, H. (1998). Bacillus popilliae cry18Aa operon is transcribed by sigmaE and sigmaK forms of RNA polymerase from a single initiation site. [Research Support, Non-U.S. Gov't]. Nucleic Acids Res, 26(5), 1288-1293.

ZHANG, Q., HUA, G., BAYYAREDDY, K., \& ADANG, M.J. (2013). Analyses of alpha-amylase and alpha-glucosidase in the malaria vector mosquito, Anopheles gambiae, as receptors of Cry11Ba toxin of Bacillus thuringiensis subsp. jegathesan. [Research Support, N.I.H., Extramural]. Insect Biochem Mol Biol, 43(10), 907-915. doi: 10.1016/j.ibmb.2013.07.003

ZHANG, X., CANDAS, M., GRIKO, N.B., ROSE-YOUNG, L., \& BULLA, L.A., JR. (2005). Cytotoxicity of Bacillus thuringiensis Cry1Ab toxin depends on specific binding of the toxin to the cadherin receptor BT-R1 expressed in insect cells. Cell Death Differ, 12(11), 1407-1416. doi: 10.1038/sj.cdd.4401675

ZÚÑIGA-NAVARRETE, F., GÓMEZ, I., PEÑA, G., BRAVO, A., \& SOBERÓN, M. (2013). A Tenebrio molitor GPI-anchored alkaline phosphatase is involved in binding of Bacillus thuringiensis Cry3Aa to brush border membrane vesicles. Peptides, 41(0), 81-86. doi: http://dx.doi.org/10.1016/j.peptides.2012.05.019 


\section{Anexos}

\section{Seção I}

Material \& Métodos 


\title{
ANEXO 1 - Sequências de Cry1Ab e BT-R ; e modelos de script e alinhamento usados no MODELLER.
}

\begin{abstract}
>gi|359392456|gb|AEV45790.1| CrylAb [Bacillus thuringiensis] MDNNPNINECI PYNCLSNPEVEVLGGERIETGYTPIDISLSLTQFLLSEFVPGAGFVLGLVDI IWGIFGP SQWDAFLVQIEQLINQRIEEFARNQAISRLEGLSNLYQIYAESFREWEADPTNPALREEMRIQFNDMNSA LTTA I PLFAVQNYQVP LLSVYVQAANLHLSVLRDVSVFGQRWGFDAAT INSRYNDLTRLIGNYTDHAVRW YNTGLERVWGPDFRDWIRYNQFRRELTLTVLDIVSLFPNYDSRTYPIRTVSQLTREIYTNPVLENFDGSF RGSAQGIEGS IRS PHLMDI LNS IT IYTDAHRGEYYWSGHQ IMASPVGFSGPEFTFPLYGTMGNAAPQQRI VAQLGQGVYRTLSSTLYRRPFNIGINNQQLSVLDGTEFAYGTSSNLPSAVYRKSGTVDSLDEI P PQNNNV PPRQGFSHRLSHVSMFRSGFSNSSVSI IRAPMFSWI HRSAEFNNI I PSSQITQI PLTKSTNLGSGTSVVK GPGFTGGDILRRTSPGQISTLRVNITAPLSQRYRVRIRYASTTNLQFHTSIDGRP INQGNFSATMSSGSN LQSGSFRTVGFTTPFNFSNGSSVFTLSAHVFNSGNEVYIDRIEFVPAEVTFEAEYDLERAQKAVNELFTS SNQIGLKTDVTDYHIDQVSNLVECLSDEFCLDEKKELSEKVKHAKRLSDERNLLQDPNFRGINRQLDRGW RGSTDITIQGGDDVFKENYVTLLGTFDECYPTYLYQKIDESKLKAYTRYQLRGYIEDSQDLEIYLIRYNA KHETVNVPGTGSLWPLSAPSP I GKCAHHSHHFS LDI DVGCTDLNEDLGVWVIFKIKTQDGHARLGNLEFL EEKPLVGEALARVKRAEKKWRDKREKLEWETNIVYKEAKESVDALFVNSQYDRLQADTNIAMI HAADKRV HSIREAYLPELSVIPGVNAAI FEELEGRIFTAFSLYDARNVIKNGDFNNGLSCWNVKGHVDVEEQNNHRS VLVVPEWEAEVSQEVRVCPGRGY I LRVTAYKEGYGEGCVT I HE IENNTDELKF SNCVEEEVYPNNTVTCN DYTATQEEYEGTYTSRNRGYDGAYESNSSVPADYASAYEEKAYTDGRRDNPCESNRGYGDYTPLPAGYVT KELEYFPETDKVWIEIGETEGTFIVDSVELLLMEE
\end{abstract}

\footnotetext{
>gi|11545674|gb|AAG37912.1|AF319973_2 cadherin-related protein receptor BT-R1 [Manduca sexta]

MAVDVRIAAFLLVFIAPAVLAQERCGYMTAI PRLPRPDNLPVLNFEGQTWSQRPLLPAPERDDLCMDAYH VITANLGTQVIYMDEEIEDEITIA I LNYNGP STPFIELPFLSGSYNLLMPVIRRVDNGEWHLI ITQRQHY ELPGMQQYMFNVRVDGQSLVAGVSLAIVNI DDNAP I IQNFE PCRVPELGEPGLTECTYQVSDADGRISTE FMTFRIDSVRGDEETFYIERTNI PNQWMWLNMT I GVNTS LNFVTSPLHIFSVTALDSLPNTHTVTMMVQV ANVNSRP PRWLEIFAVQQFEEKSYQNFTVRAIDGDTE INMP INYRLITNEEDTFFS IEALPGGKSGAVFL VSPIDRDTLQREVFPLTIVAYKYDEEAFSTSTNVVI IVTDINDQRPEP I HKEYRLAIMEETPLTLNFDKE FGFHDKDLGQNAQYTVRLESVDP PGAAEAFYIAPEVGYQRQTF IMGTLNHSMLDYEVPEFQSITIRVVAT DNNDTRHVGVALVHIDLINWNDEQP IFEHAVQTVTFDETEGEGFFVAKAVAHDRDIGDVVEHTLLGNAVN FLTIDKLTGDIRVSANDSFNYHRESELFVQVRATDTLGEPFHTATSQLVIRLNDINNTPPTLRLPRGSPQ VEENVPDGHVITQELRATDPDTTADLRFEINWDTSFATKQGRQANPDEFRNCVEIETIFPEINNRGLAIG RVVAREIRHNVTI DYEEFEVLSLTVRVRDLNTVYGDDYDESMLTITI I DMNDNAPVWVEGTLEQNFRVRE MSAGGLVVGSVRADDI DGPLYNQVRYTIFPREDTDKDLIMI DFLTGQISVNTSGA IDADTPPRFHLYYTV VASDRCSTEDPADCPPDPTYWETEGNITIHITDTNNKVPQAETTKFDTVVYIYENATHLDEVVTLIASDL DRDEIYHTVSYVINYAVNPRLMNFFSVNRETGLVYVDYETQGSGEVLDRDGDEPTHRIFFNLIDNFMGEG EGNRNQNDTEVLVILLDVNDNAPELPPPSELSWTISENLKQGVRLEPHIFAPDRDEPDTDNSRVGYEILN LSTERDIEVPELFVMIQIANVTGELETAMDLKGYWGTYAIHIRAFDHG I PQMSMNETYELI IHPFNYYAP EFVFPTNDAVIRLARERAVINGVLATVNGEFLERISATDPDGLHAGVVTFQVVGDEESQRYFQVVNDGEN LGSLRLLQAVPEEIREFRITIRATDQGTDPGPLSTDMTFRVVFVPTQGEPRFASSEHAVAFIEKSAGMEE SHQLPLAQDIKNHLCEDDCHS IYYRI I DGNSEGHFGLDPVRNRLFLKKELIREQSASHTLQVAASNSPDG GIPLPAS ILTVTVTVREADPRPVFVRELYTAGISTADSIGRELLRLHATQSEGSAITYAIDYDTMVVDPS LEAVRQSAFVLNAQTGVLTLNIQPTATMHGLFKFEVTATDTAGAQDRTDVTVYVVSSQNRVYFVFVNTLQ QVEDNRDFIADTFSAGFNMTCNIDQVVPANDPVTGVALEHSTQMRGHFIRDNVPVLADEIEQIRSDLVLL SSIQTTLAARSLVLQDLLTNSSPDSAPDSSLTVYVLASLSAVLGFMCLVLLLTFI IRTRALNRRLEALSM TKYGSLDSGLNRAGIAAPGTNKHTVEGSNPIFNEAIKTPDLDAISEGSNDSDLIGIEDLPHFGNVFMDPE VNEKANGYPEVANHNNNEAFNPTPFSPEFVNGQFRKI
} 


\section{Script para MODELLER}

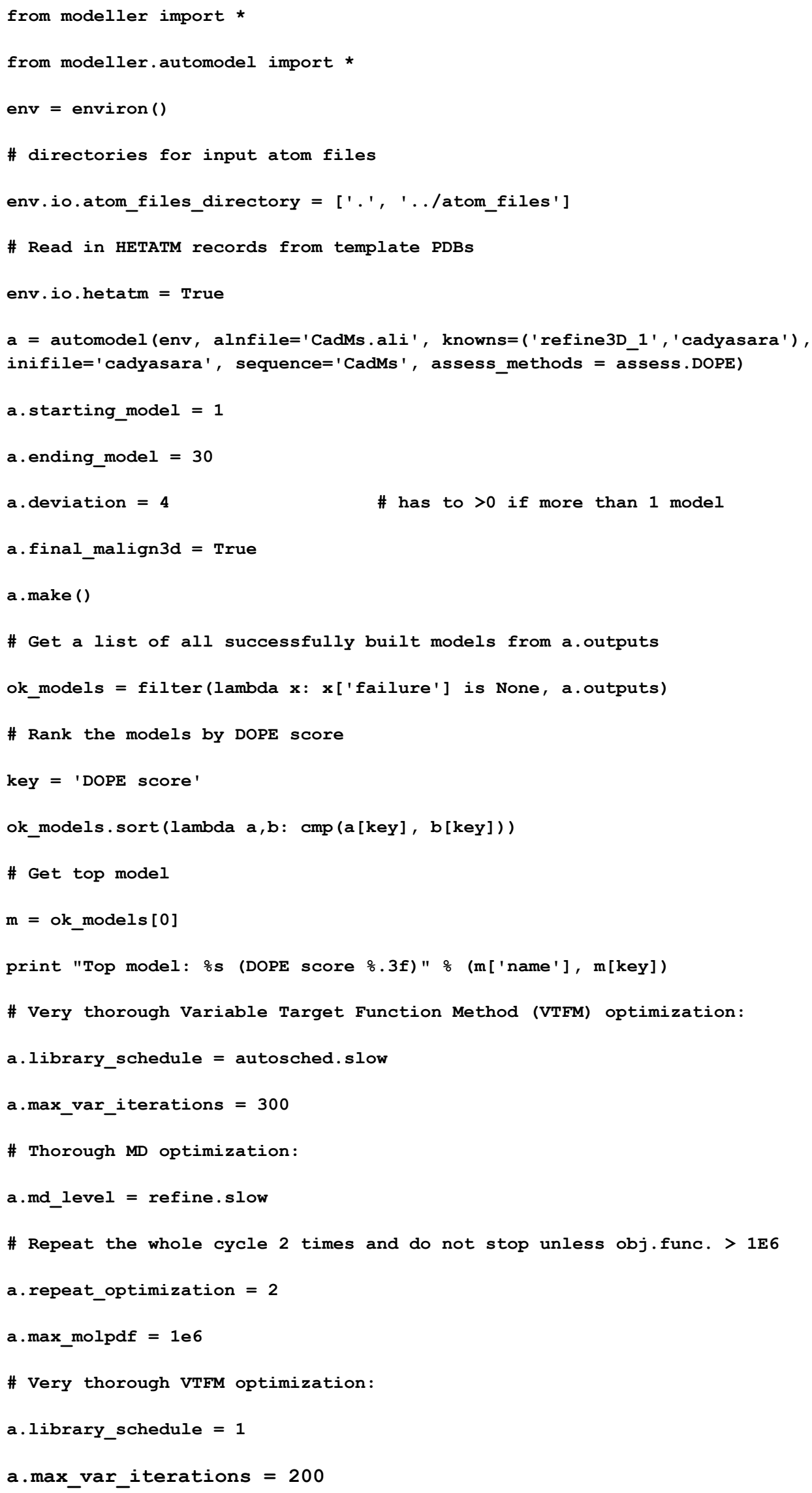




\section{Alinhamento para MODELLER}

\section{$>$ P1;CadMs}

sequence:CadMs : : $\quad:::: 0.00: 0.00:$

ETTKFDTVVYIYENATHLDEVVTLIASDLDRDE-IYHTVSYVINYAVNPRLMNFFSVNRE TGLVYVDYETQGSGEVLDRDGDEPTHRIFFNLIDNFMGEGEGNRNQNDTEVLVILLDVND NAPELPPPSELSWTISENLKQGVRLEPHIFAPDRDEP-DTDNSRVGYEILNLSTERDIEV PELFVMIQIANVTGELETAMDLKGYWGTYAIHIRAFDH-GIP--QMSMNETYELI IHPFN YYAPEFVFPTNDAVIRLARERAVINGVLATVNGEFLERISATDPD--GLHAGVVTFQVVG DEESQRYFQVVNDGENLGSLRLLQAVPEEIRE-FRITIRATDQGTDPGPL---STDMTFR VVFVPTQGE--PRFASSEHAVAF IEKSAGMEESHQLPLAQDIKNHLCEDDCHS - IYYRI IDGNSEGHFGLDPVRNRLFLKKELIRE-----QSASHTLQVAASNSPDGGIPLPASI-------LTVTVTVRE-ADPRPVFVRELYTAGISTADSIGRELLRLHATQSEGSAIT----Y AIDYDTMVVDPSLEAVRQSAFVLNAQTGVLTLNIQPTATMH-GLFKFEVTATDTAGAQD-----RTDV------------........*

$>\mathrm{P} 1 ; 1 \mathrm{~L} 3 \mathrm{~W}$

structureX:1L3W:1:A:611: ::: :

DWVIPPIKVSENERGPFPKRLVQIKSN-KDRFNKVYYSIT---GQGADNPPQGVFRIEWE TGWMLVT-------RPLDREEYDKYVLSSHAVSEN------GSPVEEPMEITINVIDQND NRPKF-TQDVFRGSVREGVQPGTQVMA-VSATDEDDNIDSLNGVLSYSI--LKQDPEEPI PNLFTINRETGVISLIGTGLD-REKFPEYTLTVQATDLEGA---GLSVEGKAI IQITDAN DNAPIFDPKTYTALV--PENE----------IGFEVQRLSVTDLDMPGTPAWQAVYKIRVNEGGFFNITTDPESNQGILTTAKGLDFELRKQYVLQITVENAEPFSVPL---PTSTATV TVTVEDVNEA-PFFVPAVSRVDVSEDLSRGEKI ISL-------VAQDPDKQQIQKLSY-F IGNDPARWLTVNKDNGIVTGNGNLDRE-SEYVKNNTYTVIMLVTDD---GVSVGTGT-------GTLILHVLDVNDNGPVPSPRVFT---MCDQNPEP--QVLTISDADIPPNT----Y PYKVS---LSHGS---DLTWKAELDSKGT-SMLLSPTQQLKKGDYS IYVLLSDAQNNPQ-ITVVNATVCSCEGKAIKCQ--------------*

$>\mathrm{P} 1 ; 3 \mathrm{Q} 2 \mathrm{~V}$

structureX:3Q2V:1:A:536: : : : :

DWVIPPISCPENEKGEFPKNLVQIKSN-RDKETKVFYSIT---GQGADKPPVGVFIIERE TGWLKVT-------QPLDREAIAKYILYSHAVSSN------GEAVEDPMEIVITVTDQND NRPEF-TQEVFEGSVAEGAVPGTSVMK-VSATDADDDVNTYNAAIAYTI--VSQDPELPH KNMFTVNRDTGVISVLTSGLD-RESYPTYTLVVQAADLQGE---GLSTTAKAVITVKDIN DNAPVFNPSTYQGQV--PENE----------VNARIATLKVTDDDAPNTPAWKAVYTVVNDPDQQFVVVTDPTTNDGILKTAKGL---DFEAKQQYILHVRVENEEPFEGSLVPSTATV TVDVVDVNEA-PIFMPAERRVEVPEDFGVGQEITSY-------TAREPDTFMDQKITY-R IWRDTANWLEINPETGAIFTRAEMDREDAEHVKNSTYVALI IATDD---GSPIATGT-------GTLLLVLLDVNDNAPI PEPRNMQ---FCQRNPQP--HI ITILDPDLPPNT----S PFTAE---LTHGA---SVNWT IEYNDAAQESLILQPRKD----EYKIHLKLADNQNKDQ-VTTLDVHVCDCEG-----------------*

$>\mathrm{P} 1 ; 3 \mathrm{Q} 2 \mathrm{~W}$

structureX:3Q2W:1:A:542: : : : :

DWVI PPINLPENSRGPFPQELVRIRS-DRDKNLSLRYSVT---GPGADQPPTGIFIINPI SGQLSVT-------KPLDRELIARFHLRAHAVDIN------GNQVENPIDIVINVIDMND NRPEF-LHQVWNGSVPEGSKPGTYVMT-VTAIDADDP-NALNGMLRYRI--LSQAPSTPS PNMFT INNETGDI ITVAAGLD-REKVQQYTLI IQATDMEGNPTYGLSNTATAVITVTDVN DNPPEFTAMTFYGEV--PENR---------VDVIVANLTVTDKDQPHTPAWNAAYRISG GDPTGRFAILTDPNSNDGLVTVVKPIDFETNRMFVLTVAAENQVPLAKGIQHPPQSTATV SVTVIDVNEN-PYFAPNPKIIRQEEGLHAGTMLTTL-------TAQDPDRYMQQNIRY-T KLSDPANWLKIDPVNGQITTIAVLDRE-SPNVKNNIYNATFLASDN---GI PPMSGT-------GTLQIYLLDINDNAPQVLPQEAE---TCE-TPEPNSINITALDYDIDPNA----G PFAFD---LPLSPVTIKRNWTINRLNGDFAQLNLK-IKF-EAGIYEVPIIITDSGNPPKS NISILRVKVC---------------------* 


\title{
ANEXO 2 - Troca de email com Dr. Jurat-Fuente, Dr. Hua e Dr. Adang esclarecendo a importância do MPED para ligação às toxinas Cry1A.
}

\author{
Print I Close Window \\ Subject: RE: Concerning the MPED from cadherins. \\ From: "Jurat-Fuentes, Juan Luis" <jurat@ieutk.edu> \\ Date: Tue, Aug 12, 2014 10:42 am \\ To: Diogo Martins de Sá <sadiogoedmol.bio.br>
}

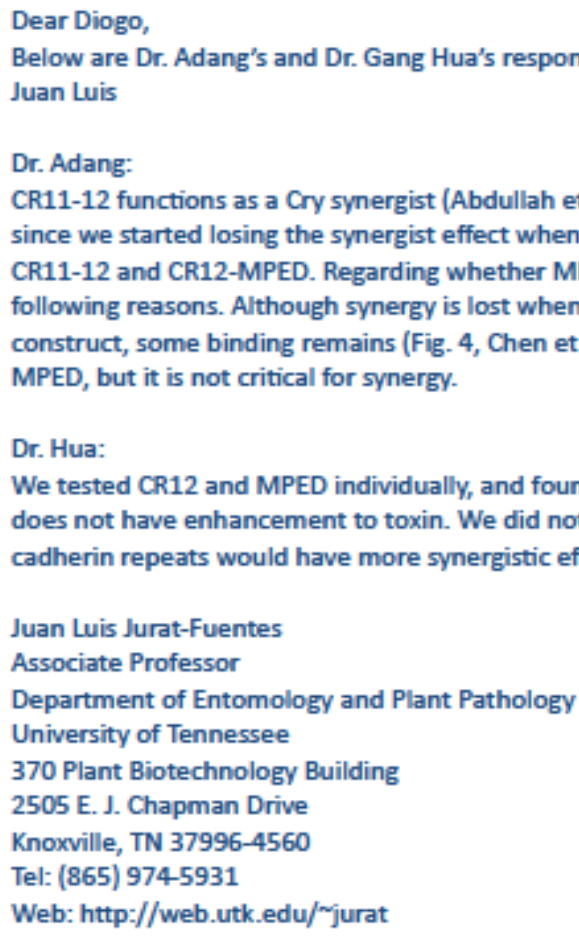

Juan Luis Jurat-Fuentes

Associate Professor

Department of Entomology and Plant Pathology

University of Tennessee

370 Plant Biotechnology Building

2505 E. J. Chapman Drive

Knoxville, TN 37996-4560

Tel: (865) 974-5931

Web: http://web.utk.edu/ jurat

We tested CR12 and MPED individually, and found CR12 is almost the same as CR12-MPED, but MPED only does not have enhancement to toxin. We did not test CR11 only. But I remember that Insectigen reported more cadherin repeats would have more synergistic effect to toxins (did by Amir).

From: Diogo Martins de Sá [mailto:sadiogo@mol.bio.br]

Sent: Tuesday, August 12, 2014 8:47 AM

To: Jurat-Fuentes, Juan Luis

Subject: RE: Concerning the MPED from cadherins.

Dear Juan Luis,

thank you for forwarding my message to Dr. Michael Adnag and Dr. Gang Hua.

The objetive of my work is providing a reliable model for which Cry1A toxins bind cadherins. Cry toxins are quite promiscuous, with a total of 6 putative receptors so far and a new mechanism being proposed every year (I have a diferent hypothesis myself). But for Cry1A toxins, I believe that specificity to the order and species of insects is most clearly defined during its binding to cadherins, as they almost always appear as the first receptor in the proposed mechanisms. The goal of my model is to optimally engineer Cry1A toxins and to propiciate a model from which new hypotheses can be infered. It is my impression that the MPED does not play a role in specificity, but if by any chance it may be involved in Cry toxin binding, I have to reconsider the cadherin region I've modeled. Considering, however, that the cadherin MPED does not participate in specific binding of Cry toxins, I already have 3 cadidate epitopes that, combined, may be responsible for specificity. Two of them are new and have never been described, though there some obscure indicatives of there involvement in literature. I have already started to test my model with some in vitro SPR experiments. I am presently working with peptides (15 to $20 \mathrm{aa}$ long) corresponding to the 7 binding epitopes I've found. While my first results are encouraging, I have found that using only small peptides is a bit troublesome to work with in SPR. A 
ANEXO 3 - Função Kyte \& Doolittle de hidropaticidade para Excel.

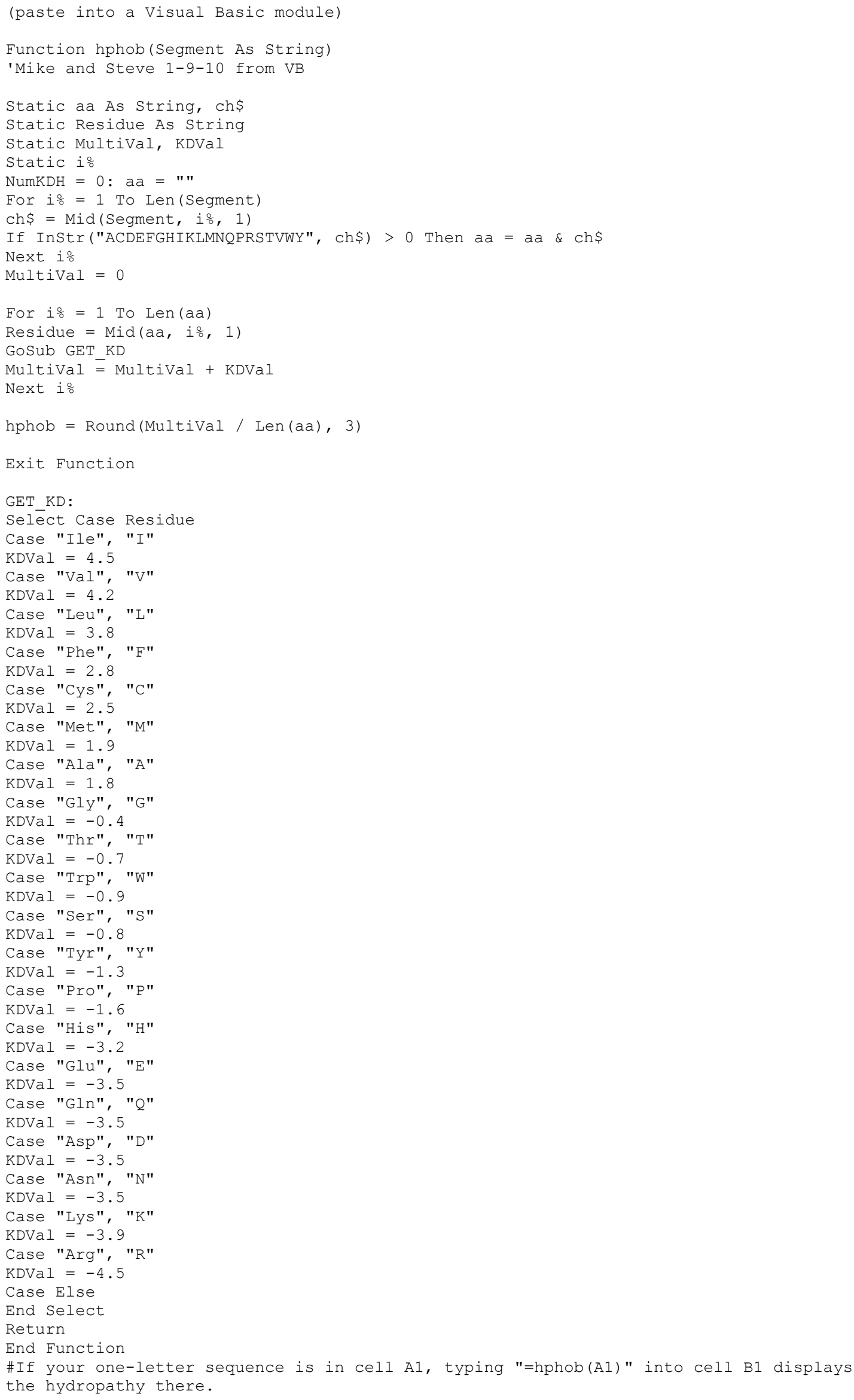




\section{ANEXO 4 - Nota de atualização do GROMACS v.4.6.3}

\section{Changes that might affect your results}

None for simulations set up with the traditional group cut-off scheme.

When switching from the group scheme to the Verlet scheme, integration of the equations of motion can get more accurate due to the exact cut-off treatment and buffering (this will, of course, depend on the original cut-off settings used). See the section Cut-off schemes for details.

Traditionally Gromacs has used pair-lists based on groups of atoms. These groups of atoms were orginally charge-groups, which were necessary with plain cut-off electrostatics. With the use of PME (or reaction-field with a buffer) charge groups were no longer necessary. Most force fields and MD packages do not use charge groups. In Gromacs the group based cut-off scheme is still used, mainly because it allows for extremely efficient non-bonded kernels for water, which is the most abundant molecule in (bio-)molecular simulations. The group cut-off scheme can be combined with a buffered pair-list, but this is tedious as is needs to be combined with tabulated potentials with continuous energy and force at the cut-off.

This main reason for implementing the, more common, buffered Verlet list scheme in version 4.6 was that a group scheme is inconvenient for streaming architectures such as GPUs. The new verlet scheme also works well on CPUs with SSE and AVX. Only for systems with a lot of water where energy conservation is not of primary concern the group pair-list scheme is faster. The Verlet list scheme has buffered neighborlists with exact cut-off's. Both the LJ and Coulomb potential are by default shifted to zero by subtracting the value at the cut-off. This ensures that the energy is the integral of the force. Still it is advisable to have small forces at the cut-off, hence to use PME or reaction-field with infinite epsilon.

The Verlet list scheme uses a new code path for the non-bonded interactions. In this code path charge groups are completely ignored. Particle pair forces (and energies when necessary) are calculated in groups of $4 \mathrm{vs} 4$ or $4 \mathrm{vs} 8$ particles. This is convenient for streaming but leads to a significant amount of zero interactions being calculated beyond the cut-off; this does not happen in the standard setup with the group cut-off scheme. 
ANEXO 5 - Linhas de comando para rodar dinâmica no GROMACS.

\# Para gerar arquivo de .gro, de topologia (.top) e .itp (para caso de mais de uma cadeia)

pdb2gmx_d -f (protein).pdb -o (protein).gro -p (protein).top -i (protein).itp

\# Selecione o campo de força a ser utilizado quando lhe for solicitado. Por padrão usase o $43 \mathrm{a} 1$.

\# Selecione o solvente a ser utilizado quando lhe for solicitado. Por padrão usa-se o SPC.

Obs.: Se seu pdb tiver heteroatomos, verifique a ligação que cada um faz com outros atomos (pode-se utilizar o server lpccsu). Será necessário adicionar em sua topologia todas as ligações envolvidas, bem como indicar qual a ligação (tipo, distancia e denotação a ser utilizada) no arquivo:

/usr/local/gromacs/share/gromacs/top/gromos43a1.ff/ffbonded.itp

\section{\# Para gerar caixa}

editconf_d -f (protein).gro -o (protein)_box.gro -c -d 1.0

Legenda:

-c (usado para centralizar caixa, não colocar valor)

- $d$ (distancia entre parade da caixa e molecula, dado em nanometros. Geralmente usase valor 1.0)

-bt (formato da caixa, normalmente usa-se cubic)

\section{\#Para encher a caixa com solvente}

genbox_d -cp (protein)_box.gro -cs -o (protein)_H2Obox.gro -p (protein).top

Legenda:

-cs (para encher com solvente, deixar em branco para utlizar solvente padrão)

Obs.: Verificar no final topologia (.top) se solvente foi adicionado.

\section{\# Para gerar .tpr a ser utilizado pelo mdrun na minimização}

grompp_d -f em_steep.mdp -c (protein)_H2Obox.gro -p (protein).top -o (protein)_min.tpr

Legenda:

em_steep.mdp (arquivo script para gerar .tpr da minimização) 


\section{\# Em caso de desequilibrio de cargas (ver resultado do grompp), equilibrar com}

genion

genion_d -s (protein)_min.tpr -o (protein)_ion.gro -np (x) -pname (XX) -pq (y)

Legenda:

-np (numero de ions a ser utilizado)

-pname (sigla do ion, NA ou CL)

-pq (carga do ion, ex. 1 ou -1 )

Obs.: Adicionar quantidade de ION de equilibrio e subtrair igualmente do solvente no final do arquivo de topologia.

\section{\# Refazer arquivo .tpr após equilibrio de cargas}

grompp_d -f em_steep.mdp -c (protein)_ion.gro -p (protein).top -o (protein)_min_ion.tpr

\section{\# Para rodar minimização}

mdrun_d -v -s (protein)_min_ion.tpr -o (protein)_min.trr -c (protein)_min.gro -e (protein)_min.edr -g (protein)_min.log $>\&$ (protein)_min.job \&

Legenda:

\& (para rodar em off)

\section{\# Enquanto roda a minimização, preparar/atualizar adequadamente arquivos} md term, mdp_full e lista

Obs.: Lembrar de adicionar Ion de equilibrio e heteroatomo (caso houver) nos arquivos md_terme $m d \_f u l l$, bem como tau_t e ref_t.

$E X:$

tc-grps $\quad=$ Protein SOL NACA

tau_t $\quad=0.10 .10 .10 .1$

$r e f \_t \quad=50505050$

; Energy monitoring

energygrps $\quad=$ Protein SOL NACA

Obs.2: Na lista basta substuir os nomes dos arquivos com o de sua (protein). Utilize ferramenta "replace" do editor de texto. Verifique se o primeiro arquivo input corresponde ao .gro gerado após minimização. 


\section{ANEXO 6 - parâmetros do arquivo mdp para minimização de energia}

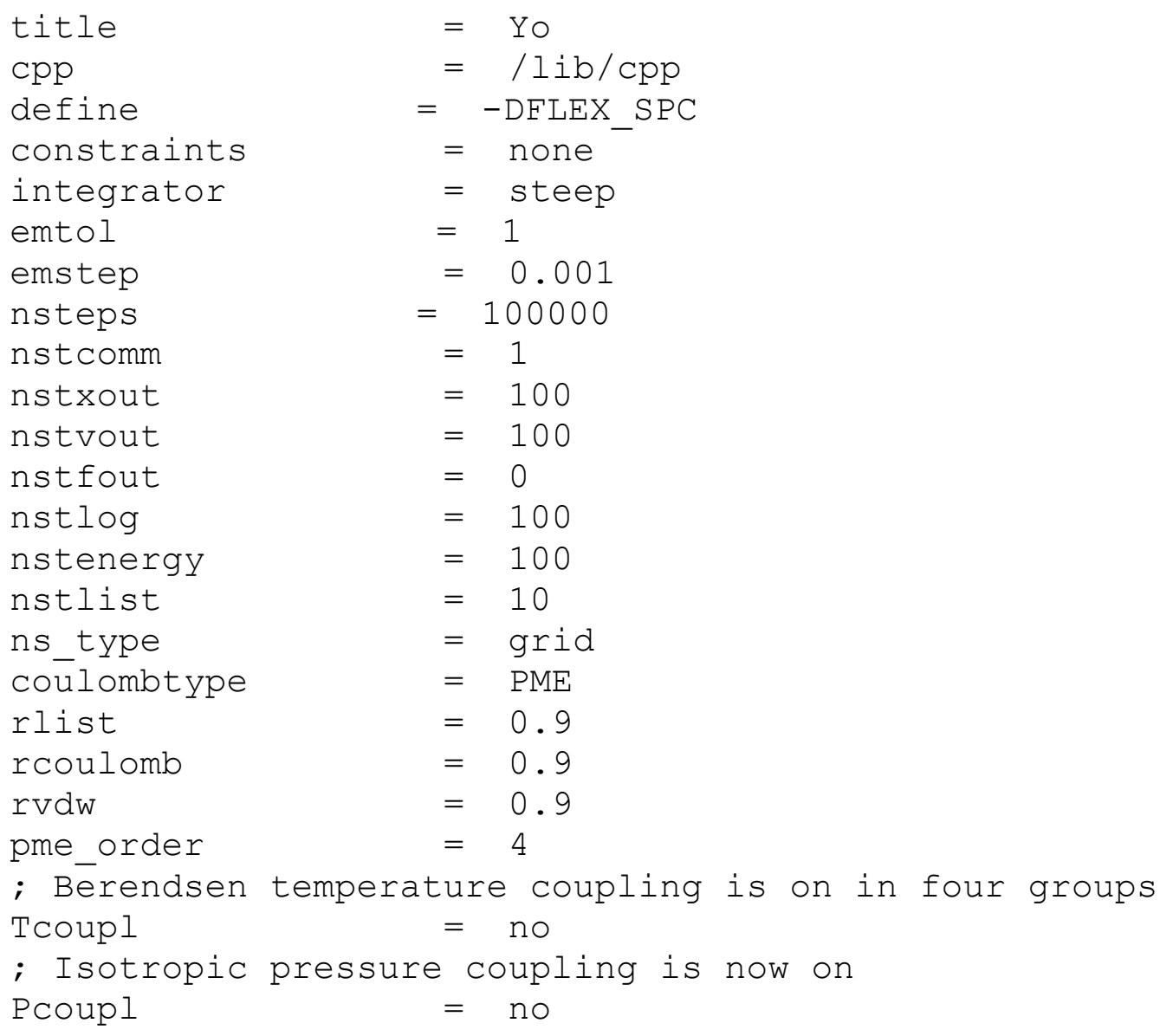




\section{ANEXO 7 - parâmetros do arquivo mdp para termalização de energia}

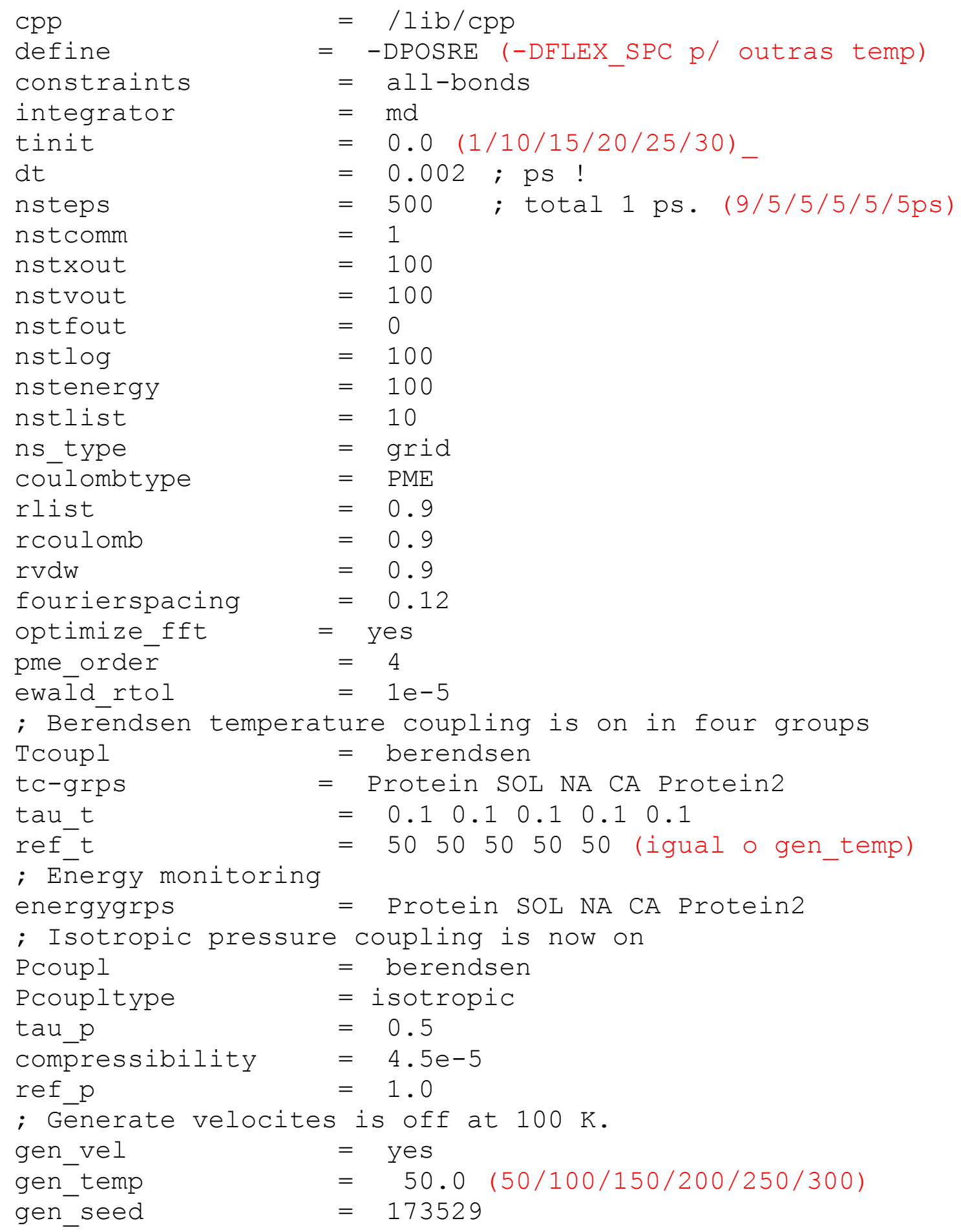




\section{ANEXO 7 - parâmetros do arquivo mdp para dinâmica}

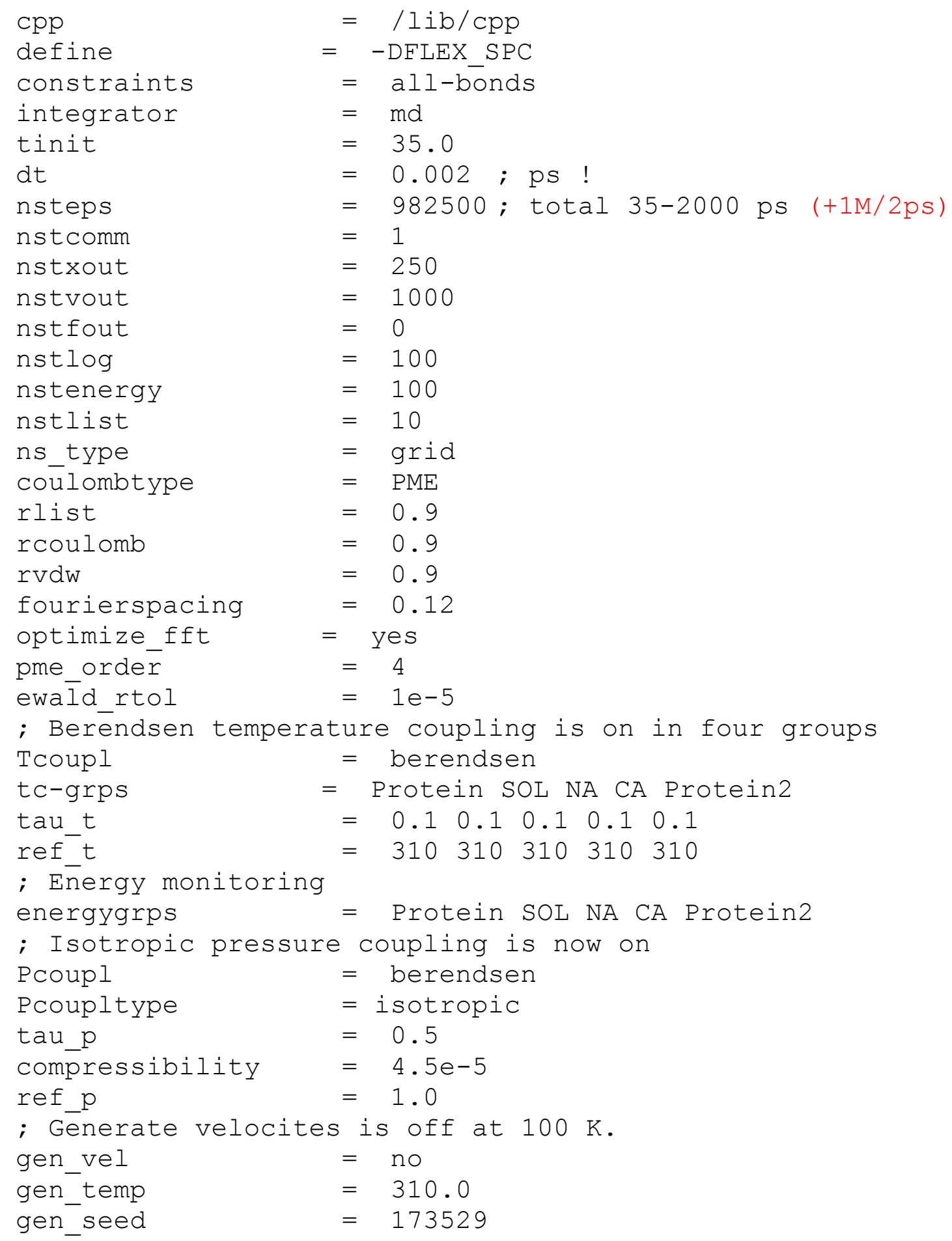




\section{ANEXO 8 - lista de arquivos/eventos da simulação}

\#grompp_d -f md_term-a.mdp -c cadms-crylab_min.gro -p cadms-crylab.top -o cadms-crylab_term_a.tpr

\#mdrun_d -v -s cadms-crylab term_a.tpr -o cadms-crylab term_a.trr -c cadmscrylab_term_a.gro -e cadms-crylab_term_a.edr -g cadms-crylab_term_a.log

\#grompp_d -f md_term-b.mdp -c cadms-crylab_term_a.gro -p cadms-crylab.top -o cadms-crylab term b.tpr

\#mdrun_d -v -s cadms-crylab_term_b.tpr -o cadms-crylab_term_b.trr -c cadmscrylab_term_b.gro -e cadms-crylab_term_b.edr -g cadms-crylab_term_b.log

\#grompp_d -f md_term-c.mdp -c cadms-crylab_term_b.gro -p cadms-crylab.top -o cadms-crylab_term_c.tpr

\#mdrun_d $-\mathrm{v}-\mathrm{s}$ cadms-crylab_term_c.tpr -o cadms-crylab_term_c.trr -c cadmscrylab_term_c.gro -e cadms-crylab_term_c.edr -g cadms-crylab_term_c.log

\#grompp_d -f md_term-d.mdp -c cadms-crylab_term_c.gro -p cadms-crylab.top -o cadms-crylab_term_d.tpr

\#mdrun d - - - cadms-crylab term d.tpr -o cadms-crylab term d.trr -c cadmscrylab_term_d.gro -e cadms-crylab_term_d.edr -g cadms-crylab_term_d.log

\#grompp_d -f md_term-e.mdp -c cadms-crylab_term_d.gro -p cadms-crylab.top -o cadms-crylab_term_e.tpr

\#mdrun_d $-\mathrm{v}-\mathrm{s}$ cadms-crylab_term_e.tpr -o cadms-crylab_term_e.trr -c cadmscrylab_term_e.gro -e cadms-crylab_term_e.edr -g cadms-crylab_term_e.log

\#grompp_d -f md_term-f.mdp -c cadms-crylab_term_e.gro -p cadms-crylab.top -o cadms-crylab term f.tpr

\#mdrun_d $-\mathrm{v}-\mathrm{s}$ cadms-crylab_term_f.tpr -o cadms-crylab_term_f.trr -c cadmscrylab_term_f.gro -e cadms-crylab_term_f.edr-g cadms-crylab_term_f.log

\#grompp_d -f md_term-g.mdp -c cadms-crylab_term_f.gro -p cadms-crylab.top -o cadms-črylab_term_g.tpr

\#mdrun_d - - - ${ }^{-}$cadms-crylab_term_g.tpr -o cadms-crylab_term_g.trr -c cadmscrylab_term_g.gro -e cadms-crylab_term_g.edr -g cadms-crylab_term_g.log

$\#$ \#m * $* \#$ mdout. mdp $-\mathrm{f}$

\#grompp_d -f md_full-02000.mdp -c cadms-crylab_term_g.gro -p cadms-crylab.top -o cadms-crylab_02000.tpr - n cadms-crylab.ndx

\#mdrun_d - - -s cadms-crylab_02000.tpr -o cadms-crylab_02000.trr -c cadmscrylab_02000.gro -e cadms-crylab_02000.edr-g cadms-crylab_02000.log

\#grompp d -f md full-04000.mdp -c cadms-crylab 02000.gro -p cadms-crylab.top o cadms-crylab_04000.tpr -n cadms-crylab.ndx

\#mdrun d - $\mathrm{v}$-s cadms-crylab 04000.tpr -o cadms-crylab 04000.trr -c cadmscrylab_04000.gro -e cadms-crylab_04000.edr-g cadms-crylab_04000.log

\#grompp_d -f md full-06000.mdp -c cadms-crylab_04000.gro -p cadms-crylab.top o cadms-crylab_o6000.tpr -n cadms-crylab.ndx

\#mdrun_d -v -s cadms-crylab_06000.tpr -o cadms-crylab_06000.trr -c cadmscrylab_06000.gro -e cadms-crylab_06000.edr-g cadms-crylab_06000.log

\#grompp_d -f md_full-08000.mdp -c cadms-crylab_06000.gro -p cadms-crylab.top o cadms-crylab $08000 . t p r-n$ cadms-crylab.ndx

\#mdrun_d - $-\mathrm{s}$-s cadms-crylab_08000.tpr -o cadms-crylab_08000.trr -c cadmscrylab_08000.gro -e cadms-crylab_08000.edr-g cadms-crylab_08000.log

\#grompp_d -f md_full-10000.mdp -c cadms-crylab_08000.gro -p cadms-crylab.top o cadms-crylab_10000.tpr -n cadms-crylab.ndx

\#mdrun_d - v -s cadms-crylab_10000.tpr -o cadms-crylab_10000.trr -c cadmscrylab_10000.gro -e cadms-crylab_10000.edr-g cadms-crylab_10000.10g

E por aí vai.. 


\title{
Anexos
}

\section{Seção II}

Artigos \& Patentes Publicados

\author{
(neste período)
}




\section{Molecular Approaches to Improve the Insecticidal Activity of Bacillus thuringiensis Cry Toxins}

Wagner A. Lucena ${ }^{1,2,3, \uparrow}$, Patrícia B. Pelegrini ${ }^{3, \dagger}$, Diogo Martins-de-Sa ${ }^{3,4}$,

Fernando C. A. Fonseca ${ }^{3,4}$, Jose E. Gomes Jr. ${ }^{3,4}$, Leonardo L. P. de Macedo ${ }^{3,5}$, Maria Cristina M. da Silva ${ }^{3}$, Raquel S. Oliveira ${ }^{3,5}$ and Maria F. Grossi-de-Sa ${ }^{3,5-\pi}$

1 Embrapa Cotton, Campina Grande, 58428-095, PB, Brazil; E-Mail: wagner.lucena@embrapa.br

2 Graduate Program in Cellular and Molecular Biology, Federal University of Rio Grande do Sul, Porto Alegre, 91501-970, RS, Brazil

3 Embrapa Genetic Resources and Biotechnology, Brasilia, 70779-917, DF, Brazil; E-Mails: pbpelegrini@gmail.com (P.B.P.); dmartinsdesa@gmail.com (D.M.-S.); fcafonseca@gmail.com (F.C.A.F.); jose_edilson@yahoo.com.br (J.E.G.); leonardo.lima@embrapa.br (L.L.P.M.); cristina.mattar@embrapa.br (M.C.M.S.); raquelsam@gmail.com (R.S.)

4 Department of Molecular Biology, Federal University of Brasilia, Brasilia, 70910-900, DF, Brazil

5 Post-Graduation of Genomic Sciences and Biotechnology, Catholic University of Brasilia, Brasilia, $70790-160$, DF, Brazil

$\uparrow$ These authors contributed equally to this work.

* Author to whom correspondence should be addressed; E-Mail: fatima.grossi@embrapa.br; Tel.: +55-61-3448-4705; Fax: +55-61-3448-3624.

Received: 14 May 2014; in revised form: 23 June 2014 / Accepted: 27 June 2014 /

Published: 13 August 2014

Abstract: Bacillus thuringiensis $(\mathrm{Bt})$ is a gram-positive spore-forming soil bacterium that is distributed worldwide. Originally recognized as a pathogen of the silkworm, several strains were found on epizootic events in insect pests. In the 1960s, Bt began to be successfully used to control insect pests in agriculture, particularly because of its specificity, which reflects directly on their lack of cytotoxicity to human health, non-target organisms and the environment. Since the introduction of transgenic plants expressing Bt genes in the mid-1980s, numerous methodologies have been used to search for and improve toxins derived from native Bt strains. These improvements directly influence the increase in productivity and the decreased use of chemical insecticides on 


\section{Knock-Down of Heat-Shock Protein 90 and Isocitrate Lyase Gene Expression Reduced Root-Knot Nematode Reproduction}

Isabela Tristan Lourenço-Tessutti, José Dijair Antonino Souza Junior, Diogo Martins-de-Sa, Antônio Américo Barbosa Viana, Regina Maria Dechechi Gomes Carneiro, Roberto Coiti Togawa, Janice de Almeida-Engler, João Aguiar Nogueira Batista, Maria Cristina Mattar Silva, Rodrigo Rocha Fragoso, and Maria Fatima Grossi-de-Sa

First, second, third, fourth, fifth, sixth, eighth, minth, and eleventh authors: Emhrapa Genetic Rescurces and Biotechnology, Laboratory of Molecular Plant-Pest Intaraction, Brasilin, DF, Brazil; first, second, and third authors: University of Brastia, Depurtment of Cell Biology, Graduate Program in Molecular Biology, Brasília, DF, Brazil; seventh author. Institut National de la Recherche Agronomique, Sophis. Antipolis, Fance eighth arthor. Federal Univasity of Minas Gersis, Botany Depertment, Belo Horizonte, MG, Brazil; tenth author: Embrapa Cermida, Lahontory of Phytopathology, Planalina, DF, Brazil; and eleventh author: Catholic University of Brasilia, Graduate Program in Cerndos, Labontcry of Phytcoputhology, Panaltina, DF, Br Genomic Sciences and Biotechnology, Bras
Accepted for puhlication 29 Decemher 2014 .

\section{ABSTRACT}

Lourenco-Tessuti, I T, Soum Junioc, I. D. A, Martins do Sa, D, Vians A. A. B. Carneira, R. M. D. G. Tognwa, R. C, de Almoida-Engler, J Baista, J. A. N. Silva, M. C. M. Fragosa, R. R, and Grosei-dosa, M. F. Baisa, J. A. N., Sivin, M. C. M, Fragoso, R. R, and Grossi-do.S2, M.F.

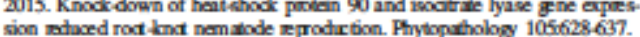

Crop losses caused by nematode infections are extimat to be valbed at USD 157 billion per year. Meladdogyne bucogniba, a roce knot nem 1 ode (RKN), is cansidered to be one of the most important plant pathogens doe to its worldwide distribution and the mastere drmage it can cuase to a large vanety of agronomically important crops. RNA intefference (RNAi), a gene silenaing process, has proven to be a valuble biotechnology altemative method for RKN control. In this staty, the RaVhi approuch was mplied, w. ing fragments of $M$ brogniba genes that enoode for two exsential molecties.

Plant nematode parasitism is one of the most important biotic stresses of several economically impontant crops (\$1). On a worldwide baxis, the annual cost of crop losses due to phytonematode damage is extimated to reach more than 157 billion US. dollars per year (1). The root-knot nematode (RKN) Meloidbgyne incognitn is considered one of the most harmful plant pathogens due to its globsil distribution and theser ious damage it causes to a large variety of plant crops. This plant nematode has a life cycle divided in six develop. mental stages (eggs, juvenile stage $1 \mathrm{~b} 4$, and adult), that lasts near 28 days (1), which ends in apomictic females laying down nearly 2,000 eggs (87). Eggr develop to J1 through embryogenesis, which turn eclode from egghell to find a plant hos. The preparasitic juveniles $(\mathrm{pp} / 2)$ are microscopic worms of $200 \mathrm{w} 400 \mu \mathrm{m}$ in kngth that penetrate the root elongation ane, migrak intercellukarly to the rook tip, and then enter the vascular cylinder where the feeding siv is established (88). To feed and complete their life cycle, these porasite choose five to seven living cells present in root vascular tisue, inject their secretionsthat will change piant cellsto giant feecling cells, which provide nutrients for nemalode development (70).Many physiological

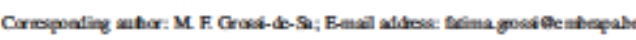

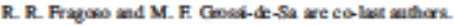

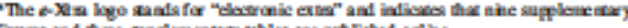

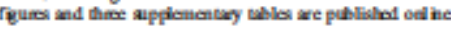

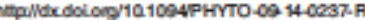

o 2015 The Amedcan Pypopathologica Sodbly

C28 PHYTOPATHOLOGY hext thook protein 90 (HSP90) and ivocitrite lyase (ICL). Plmt -medinted RNAi of these genes led to a significant level of resitunce againt $M$. brognita in the trangenio Nhotiana tahacum plantr. Bioassays of plant expresing HSP90 diRNA demonstrated a delay in gall formation

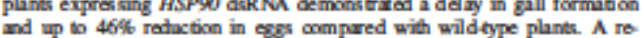
taxion in the bvel of $K S P 90$ tanouipts was observed in rcovered eges

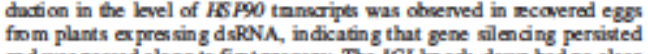
and was passed along to fist progeny. The ICL book -down had no clear effect on gall formation but resalled in up to $77 \%$ reduction in egg ovipesition compared with wild type plants. Oar data saggest that both genes may be involved in RKN development and reproduction. Thas, in this paper, we describe exsential candidite genes that codid be applied to ganente genetically modified coops, wing the RNAi smentegy to control RKN puraitism.

and morphological changes ocaur during the formation of giant celk. These feecting cells beoome hypertrophied and multinucleated as aresult of various milotic cycles without cyolinesis (22); hyperplasia is alsootsarved in olls neightboning the giant cells.

Currently, there are four primary strakgies for phylonematode control as follows: chemical tre atment with nematicides, biological control, crop rotation, and quarantine when the area is not infected with nemalodes (13). However, integrated pest management is efficient to control plant nematode just in some cases. Genetic resistance is the most effective way to circum vent RKN, but natural resistance genes axe only knownin somecrops. Theefore, a promising approsch is the application of genetic enginearing to geneste crop plants with high levels of nematode resistance ( 59 ).

RNA interference (RNAi) is a Eukarya uhiquilous physiological mechanism of gene expression regulation, which reduces transcripfion or trandation rates of a specific gene, mediated by doublestranded RNA (dsRNA). Such mecharnism became a major bchmique widely used for functionsl genomics studies (44). The first RNAi studies in plant-parasitic nematodes were performed using dsRNA soaling withegg or $\mathrm{pp} / 2$ to knock-down specific genes. This method showal different levels of geneknock-down efficiency, duration, and phenotype. The effectiveness of soviling method seems b depend on dsRNA size, concentration, incubation time, target gene and its expression pattern, and nemalode species $(5,9,10,16,30,40,46,52,79)$. In most cases, target gene expression increased within days after soaking, which is a problem to evaluate genes expressed in adult female. The limitations of the soaling method prompted the development of dRRNA expresion in plants that reportedllyis asacossful 
Anexo

(21) BR 102012 033506-9 A2

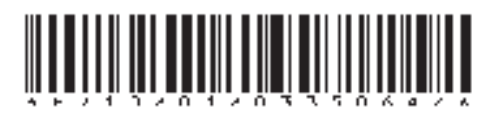

(22) Data de Deposi:o: 28' 2/2012

(43) Data de Publicaciena: 25,08;2014

(5i) int.cr.:

C12N 15.82

C12N $15: 113$

Сา2N yiר

AD1H 5 igo

A01N 65.48

AOIP 7:00

(54) TItulo: METODO E COMPOEKCXES PMRA CONTROLE GENÉTICO DE INSETOS-PRAGA EM PLANTNS DE ALGODXO NTRMVES DO

SI_ENCIAMIENTO DE GENES DA FAM:IILIA. DA LACASE

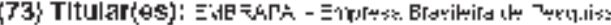

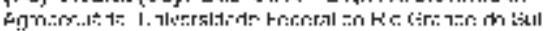

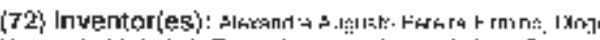

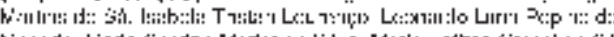

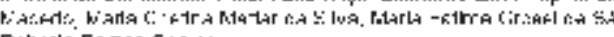
F:borls Fa Tos r.:日 is

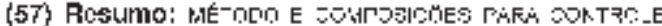

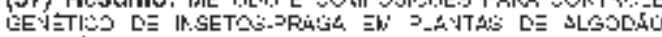

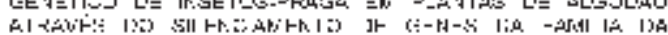
LACASE $\rightarrow$

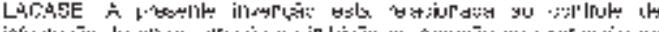

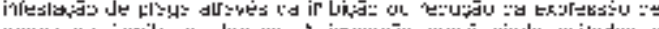

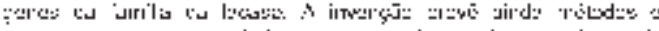

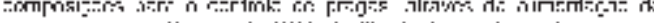

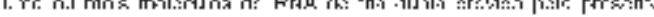
|re10.

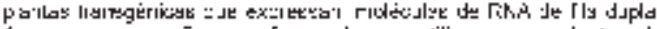

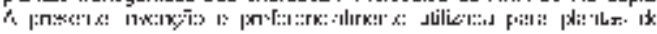
ה garosar-.

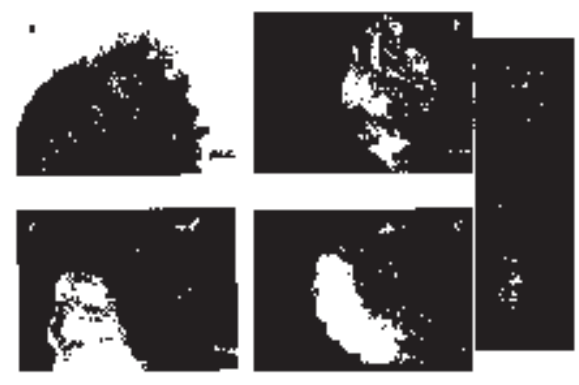




\section{Simulation of the molecular interaction of CRY1A toxins and three Aminopeptidases $\mathrm{N}$ from the sugarcane giant borer (Telchin licus licus)}

Fernando Fonseca ${ }^{1 *}$, Diogo Martins-de-Sa ${ }^{2}$, Fátima Grossi-de-Sa ${ }^{1}$, Wagner wcena ${ }^{3}$

From 5th Congress of the Brazlian Biotechnology Sodety (SBBIOTEC)

Florianópolis, Brazil. 10-14 November 2013

\section{Badkground}

Accordingly to the pore formation model, Bacillus thuringiensis CRY1A toxins, once activated in the midgut of a susceptible insect, participates on a series of binding with protein receptors present in the intestinal epithelium. In Manduca sexta, where the mode of action is better characterized, the first interaction consists of a weak binding of a monomeric toxin to the aminopeptidase $N$ (APN) receptor, allowing it's recognition by Cadherin receptors. The protein-protein interactions induce an oligomer formation of CRY molecules, which is introduced into the plasma membrane, forming a pore that causes osmotic lysis [1]. Although there is plenty information about the activity of CRY1A toxins in $M$. sexta, the same is not observed for Telchin licus licus, an insect that is emerging as a major pest of sugarcane fields in Brazil. The present study aimed at simulating and comparing the interaction of CRY1A toxins with APN receptors of $M$. sexta and $T$. likus licus using computational programs.

\section{Methods}

The protein sequence of $M$. sexta APN1 was obtained from the GenBank database [2]. Three APN sequences of $T$. licus licus were isolated from a $c$ DNA library. CRY1Aa and a human $A P N$ protein sequences and structures were collected from the PDB database (PDB 1CTY; 2YD0) while CRY1Ab, CRY1Ac and the insect APNs structures were obtained by homology modeling. Sequence alignment was carried out using the M4T server [3]. Homology modeling was performed using MODELLER 9.10 program. Dynamics simulations were performed using
GROMACS 4.5.3. Binding of toxins to the APN receptors were simulated by molecular docking, using the ClusPro metaserver.

\section{Results and conclusions}

In average, $98 \%$ of the amino acids in the models were observed in Ramachandran 's allowed regions, indicating that the secondary structures are compatible with the crystallographic data. Root mean square deviation (RMSD) calculated for all the APN and CRY models indicated that the atoms showed the same degree of movement. Root mean square fluctuation (RMSF) calculated for the APN proteins showed that the toxin binding site in T. licus licus APNs showed greater flexibility than M. sexta APN1[4]. For the CRY toxins, the RMSF showed that loops II and III were more flexible for CRY1 Ab. The radius of gyration ( $\mathrm{Rg}$ ) calculated for the APNs indicated that $T$. licus licus APN1 has a greater volume than the other receptors. In the case of the CRY toxins, the $\mathrm{Rg}$ was similar between all the proteins. After calculating the solvent accessibility surface (SAS) for all the models, it was possible to observe that the binding site in the toxins as well as the receptors, increases the contact with the water. The molecular docking between the toxins and the receptors indicated that $T$. licus licus APN4 presented closer characteristics of binding when compared with $M$. sexta APN1. These results are the first reports of how the interaction of the toxins and receptors occurs in T. licus licus 'organism. The identification of the amino acids that participates in this interaction will be useful for the development of toxins with increased activity for this insect.

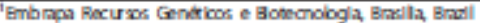

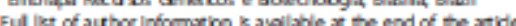

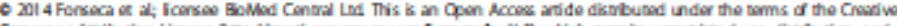


Anexo

Pebgini et al. BMC Procedings 2014, 8(Suppl 4)994

http//inwww hbmedantralcam/1753-6561/8/54/P94

\section{Identification of a new binding protein in the insect-pest midgut Heliothis virescens that interacts with Cry1 A toxins}

Patrícia Pelegrini ${ }^{1 *}$, Diogo Martins-de-Sa ${ }^{2 *}$, Jefferson Jesus ${ }^{3}$, Wagner Lucenaa ${ }^{4}$ Maria Fatima Grossi-de-Sa

From 5th Congress of the Brazilian Biotechnology Society (SBBIOTEC)

Florianópolis, Brazil. 10-14 November 2013

Bacillus thuringiensis crystal protein family (Cry) consists of a diverse group of proteins with activity against insects of different orders, such as the Lepidoptera members. Their primary action is to lyse midgut epithelial cells by inserting into the target membrane and forming pores. Among this group, members of Cry $1 \mathrm{~A}$ family are used worldwide for insect control, and their mode of action has been characterized in some detail, although it is not completely known. Cry1A-binding proteins detected on ligand blots of insect brush border membrane vesicles (BBMV) have been identified as members of the aminopeptidase $\mathrm{N}$ and cadherin families, although the relative role of the two putative receptor molecules in insects has yet to be conclusively determined. Moreover, it seems that there are other proteins in the midgut cell surface of insect-pests that can interact with Cry1Ac, leading to cell death. Therefore, in this report, we identified the gamma region of a G-protein from Helioth is virescens (HvgGP) as a potential receptor for Cry1Ac. Hence, using in silico analyses, we determined the structure of $\mathrm{Hvg} G \mathrm{P}$ and its interaction region with Cryl Ac. The binding sites was confirmed through Phage Display assays, using both Cry1 Ac and $\mathrm{HvgGP}$ as templates. Fluorescence analyses indicated that HvgGP interacts with CrylAc in a specific region. Although the mode of action through membrane pore formation was already confinmed by several in vivo and in vitro assays, the mechanism through inhibition/ activation of signalling pathways by the interaction with $G$ protein complexes is still not clear. Considering the importance of $G$ proteins on the activation of several

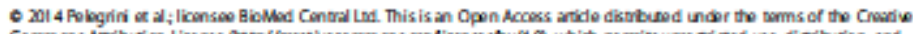

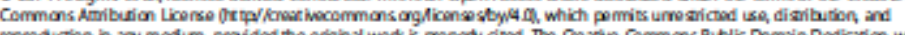

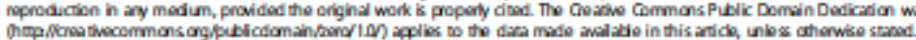

signaling pathways and the role of Cry toxins in the agribussiness, we also propose a new mechanism of action for Cryl Ac, using HvgGP as the binding protein.

\section{Authors datals}

Plampest intenction Labontory, Embrapa - Generic Recounces and

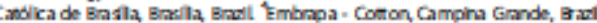

Publshed 1 Ocouba 2014

Rdences

1. Candx $M$, Gino NB Taustg R Bula LA Ir.A mechrovim of cel dexth

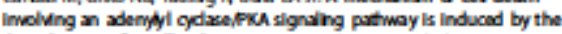

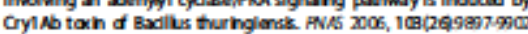

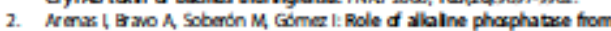
Manduca sext $\mathrm{n}$ the machanism of action of adilus thuingienas

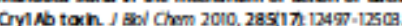

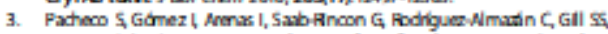
Brwo A, Soberon M: Domain il bop 3 of Baclus thuitngienak Cinn tokh $k$ imolved in a "ping pong" binding mochankm wth Mandua

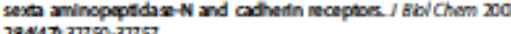
284447, 32750-3275

4. Peng $D$, Xu $X$, he $W$, Yu $Z, \operatorname{Sin} M$ : Hdilicowerpa amigara cadhar

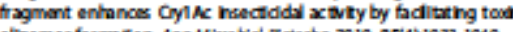
oligomer formation. App Mibobid Bchechn 2010 8S(4) 1033-1040

5. Gomez ! Pantbleper L, Munoz Gray C, Fomindez LE, Pinez C, Sinchez I, Schenth $M$. Bawo $k$ Role of recoptor interaction in the mode of action of meectadal Cy and Cya bovin produced by Badlus thuing gents.

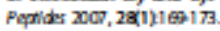

\section{doete1 186/79.6561-8.54 P94}

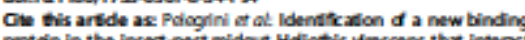
midgut Hdiotis viescens that interacts wh

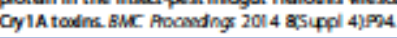




\section{Anexos}

\section{Seção III}

\section{Participações em Eventos}

Científicos \& Premiações 


\section{Certificate}

We certify that the ORAL PRESENTATION

MOLECULAR STUDIES OF A NEW RECEPTOR FROM HELIOTHIS VIRESCENS MIDGUT TO CRYIAC

was presented in the AGRIBUSINESS: ANIMAL, AGRICULTURE \& AQUICULTURE of the $16^{\text {th }}$ International Biotechnology Symposium and Exhibition, held in Fortaleza-Brazil on September $14^{\text {th }}-19^{\text {th }}, 2014$ by the authors PATRICIA BARBOSA PELEGRINI; JEFFERSON ALCÂNTARA PETRONILIO DE JESUS; DIOGO MARTINS-DE-SA; WAGNER ALEXANDRE LUCENA; MARIA FÁTIMA GROSSI DE SA.

Fortaleza, September $19^{\text {th }}, 2014$

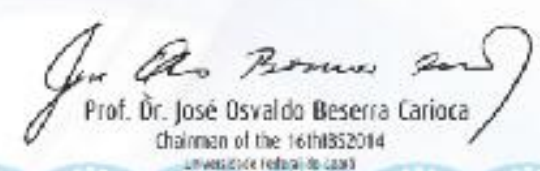
chairnan of be 16 thiss:0014

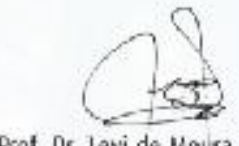

Prot. Or. Levi de Moura Barros cocod hator, Scentilic committee

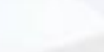




\title{
III Simpósio de Biologia Molecular PPG-BIOMOL-UnB
}

\author{
Certificamos que o trabalho
}

Modelo caracterizando a interação de toxinas da família Cry1A de Bacillus thuringiensis ao receptor tipo caderina BT-R1 de Manduca

$$
\text { sexta }
$$

com o autor

\section{Diogo Martins de Sá}

foi apresentado como POSTER no

III SIMPÓSIO DE BIOLOGIA MOLECULAR DO PROGRAMA DE PÓS-GRADUAÇÃO EM BIOLOGIA MOLECULAR DA UNIVERSIDADE DE BRASílIA, realizado em Brasília no período de 27 a 29 de novembro de 2013.

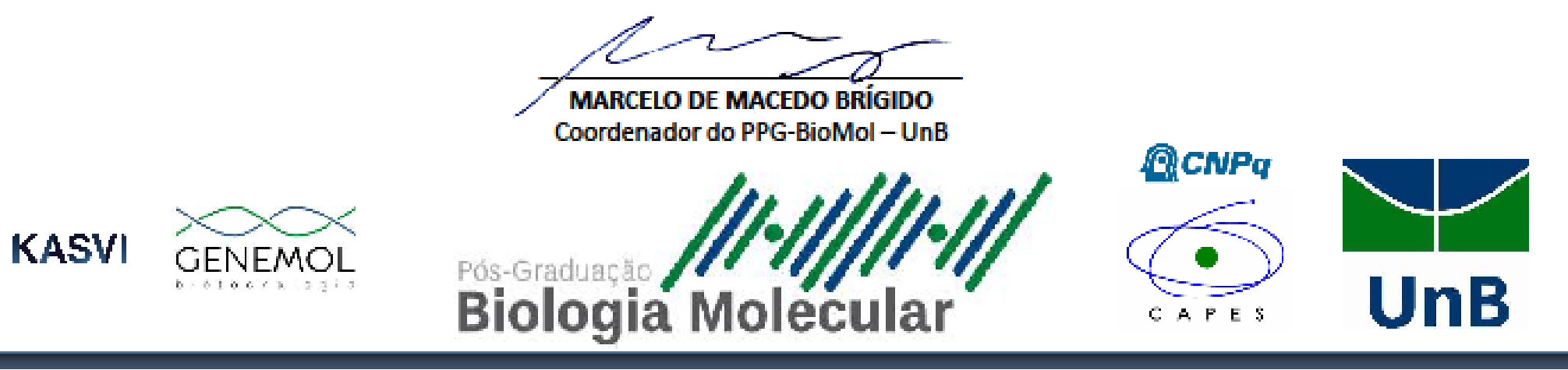




\section{Simpósio de Biologia Molecular PPG-BioMol-UnB}

\section{Certificado}

A comissão organizadora e o PPG-BioMol-UnB reconhecem o presente certificado à

\section{Diogo Martins De Sá}

ao trabalho apresentado na forma de PÔSTER com o título:

A model for the interaction between cadherin-like receptor BT-R1 and three Cry1a family toxins from Bacillus thuringiensis

durante o IV Simpósio de Biologia Molecular do Programa de Pós-graduação em Biologia Molecular da

Universidade de Brasília, realizado no Instituto de Biologia no campus Darcy Ribeiro, em Brasília no período de

19 a 21 de novembro de 2014.

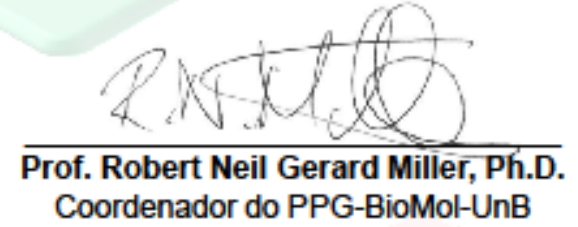

Realização/Apoio

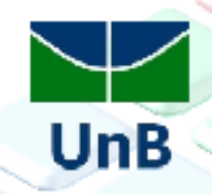

QN CNPq

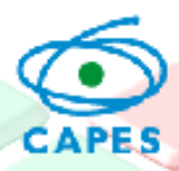




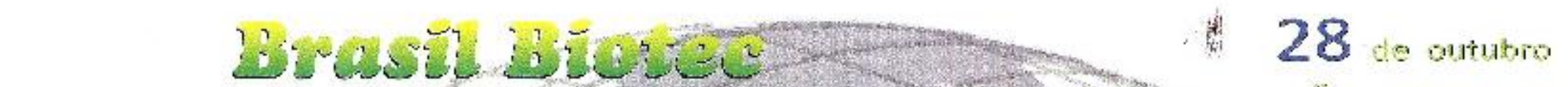

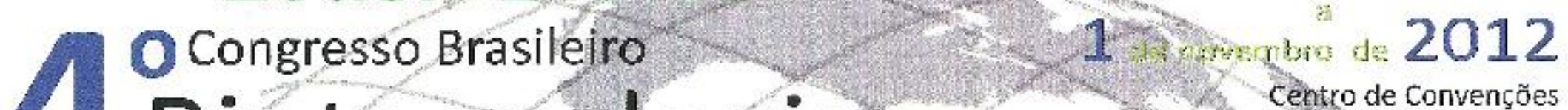 Biotecnologia \\ Centro de Convenções do Casa Graride Hotel Resort Rodada e Feira de Negócios Gutura - 50}

\section{CERTIFICADO}

A Sociedade Brasileira de Biotecnologia concede a DIOGO MARTINS DE SÁ o $1^{\circ}$ Prêmio de Pôster ao trabalho apresentado no $4^{\circ}$ Congresso Brasileiro de Biotecnologia - Rodada e Feira de Negócios de 28 de outubro a - de novembro de 2012, na cidade do Guarujá, 5P, Brasil.

Studies on molecular models simulating the interaction between Cadherin receptor BT- $\mathrm{R}_{1}$ and three Cry1A family toxins from Eacilles thurigiensis

Martins-de-Sa $\mathrm{D}^{-2}$, Fonseca FCA'. Lucera $W^{2}$, Pelegrini $\mathrm{PB}^{2}$. Grossi-de-Sa $\mathrm{M}^{-c}$

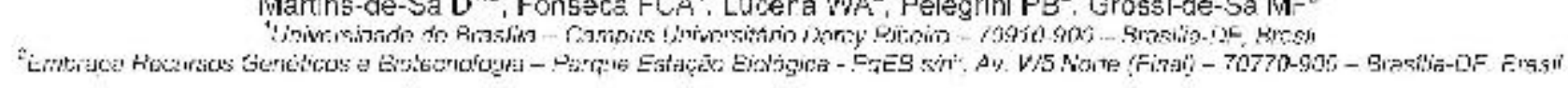

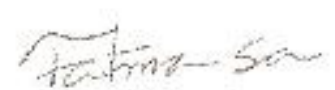

Maria Fátima Grossi de Sa

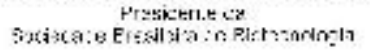

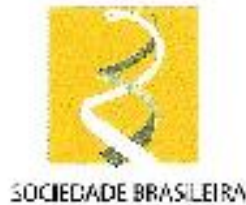

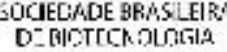

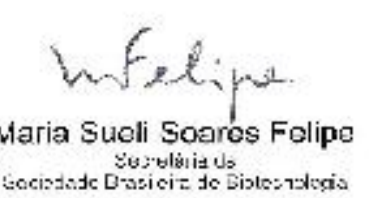




\section{SIMPÓSIO BRASILEIRO DE GENÉTICA MOLECULAR DE PLANTAS}

Bento Gompalyes - R5 is a 12 de abril de 2013

\section{Certificado}

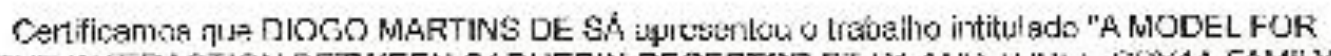
THE INIERACTION BFTWFFN CADHERIN RECEPTOR BT-RY AND I HRTE LRY IA FAMIIY TOXINS FRON BRCILLUS THURIGIENSIS" de aUtoria de MARTINS-DE-SA, D, FONGLCA, TCA, LUCENA, WIA, PELECRINI. PB. GHOSSI-DL-SA. MF, WO IV SIMPOSIO BRASILEIRO DE GENETICA MOIECUI AR DF FI ANTAG rRalizadh ma pariodo de 0 a 12 de abril de 2013, ent BENTO GONCALVES - RS, na ARE De INTERACAO PLANTA MICROORGANISMOS -

PLANI-MICKOLE INTERMCTION.
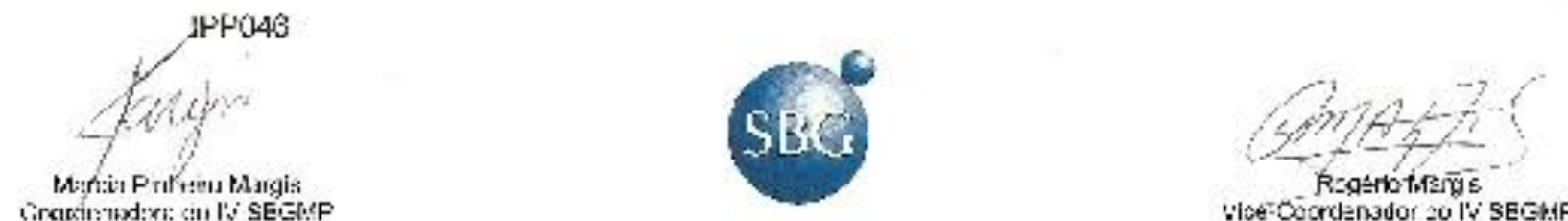

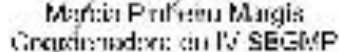

vice-coordenador 20 l'v SEGHP 
